\title{
The Nagorno-Karabakh Conflict
}

\author{
Svante E. Cornell \\ Department of East European Studies
}

\section{Report no. 46, Department of East European Studies, Uppsala University, 1999}

\section{Contents}

$\begin{array}{lll} & \text { Introduction } & 1 \\ 1 & \text { History and Roots of the Conflict } & 3 \\ 2 & \text { Escalation: 1988-91 } & 12 \\ 3 & \text { War: 1992-94 } & 29 \\ 4 & \text { Russia: the Dishonest Broker? } & 43 \\ 5 & \text { Turkey: Azerbaijan's Only Ally } & 58 \\ 6 & \text { Iran: In the Pitfalls of History } & 80 \\ 7 & \text { The United States: From Neglect to Commitment } & 95 \\ 8 & \text { Mediation and The Search for Solutions } & 115 \\ 9 & \text { Nagorno-Karabakh in Eurasian Geopolitics } & 142 \\ 10 & \text { Conclusions } & 149 \\ 11 & \text { Bibliography (Abridged) } & 153\end{array}$


Figure Error! Unknown switch argument.: Nagorno-Karabakh 


\section{Introduction}

S ince the beginning of 1988, a conflict endures between the South Caucasian nations of Azerbaijan and Armenia over the disputed area of Nagorno Karabakh. The conflict has led to over twenty thousands casualties and almost one and a half million refugees, a refugee flow which has resulted in a considerable crisis especially in Azerbaijan, with the number of displaced persons numbering close to one million. Over fourteen percent of the territory of Azerbaijan is occupied, territories which have been ethnically cleansed in the course of warfare of their Azeri population by Armenian Forces. The conflict is regarded as an internal conflict by the major powers and international organizations, and the efforts of the international community to bring an end to the conflict have been half-hearted at best and exiguous at worst. The conflict over Nagorno-Karabakh clearly possesses an intra-state dimension, that of the struggle for independence on the part of the Armenian population of Nagorno-Karabakh. However, since the beginning of 1992 the conflict also possesses an inter-state dimension in the sense that it involved two sovereign states as belligerents: Armenia and Azerbaijan. The existence of three parties to the conflict, that is the governments of the two sovereign states as well as that of the unrecognized 'Republic of Nagorno-Karabakh' is a factor which has made a solution to the conflict all the more difficult. The conflict has developed into one of the most intractable disputes in the international arena. By virtue of being the only one among the various Caucasian ethnopolitical conflicts that involve two internationally recognized states as parties, it is also the conflict of the region that carries the largest geopolitical significance. Indeed, in the late 1990s, the Nagorno-Karabakh conflict has been instrumental in accelerating the emergence of opposing alignments of states in and around the Caucasus. Whether by coincidence or by intent, the conflict plays a central role in the new geopolitics of Eurasia. As such, the unresolved nature of the conflict poses an increasingly large threat to the regional security of the Caucasus and the wider Middle East. Despite the importance that it carries, the conflict has received little media or academic coverage except in specialized regional publications; is largely ignored or in any case poorly understood by many practitioners, analysts and theoreticians of international politics.

This study aims at a comprehensive analysis of the conflict. At the outset, an attempt is made to chart briefly the controversial roots of the conflict. In chapter one, the history and roots of the 
conflict from earliest times until the late Soviet era; the chapter spans through the uproar of 1905, the commotion of 1918-21, the Soviet freeze of the 1920s that lasted until the subsequent thaw of the late 1980s. Chapter two studies in detail the re-appearance of the conflict in 1987-88 and its escalation; chapter three studies the war that lasted from 1992 to 1994. Chapter four through seven analyze the policies of the four major regional and international powers whose behavior has had a significant effect on the development of the conflict; and chapters eight and nine study the search for solutions and the geopolitical ramifications of the conflict. Finally, chapter ten attempts to conclude on the prospects of the conflict. 


\title{
1 \\ History and Roots of the Conflict
}

\begin{abstract}
'Bitterly we paid for this maturity, bitter was the price for crushing our great trust, a crushing which reminds us of 9 January 1905. We, first the people of Karabakh, then the people of Armenia, marched to the winter palace, to the Lenin square in Stepanakert, and to the theater square in Yerevan, convinced that the central power would understand us. We marched with words of trust in the land of socialism, in the Russian people, in Perestroika, with portraits of the secretary general of the party, M.S. Gorbachev. But against us fire was opened. The fire was the unjust solutions of the Politburo and the Supreme Soviet, lies created with the help of mass information, a blackening propaganda which witnessed of badly concealed benevolence to the Azerbaijani side. The fire was Sumgait.' Silva Kaputikian, 1988.
\end{abstract}

The Karabakh region is disputed on mainly historical grounds by both Azeris and Armenians. The Azeris claim that the region has always been under Azeri rule in known history; by contrast the Armenians advance the claim that Karabakh was originally an Armenian site of residence and that Azeri rule was illegitimate. The disputed and confusing history of the Karabakh region can be seen in its very name. Karabakh is actually an amalgamation of Turkish and Persian. 'Kara' means Black in Turkish, and 'baõ' means garden in Persian as well as vine in Turkish. The contemporary ending 'bakh' stems from the russification of the word 'bag'. the word 'Nagorno' simply means mountainous in Russian. Thus in the name of the region, three different languages can be found, in fact the languages of the three powers that have dominated the history of the region. The region is termed Artsakh in Armenian, and Yuqarí or Daglíq Qarabag in Azeri. The history of this borderland between Azeris and Armenians is the subject of debate, particularly as related to the circumstances surrounding its population's origin and its state affiliation. ${ }^{1}$

\section{Early History and Conflicting Claims}

Armenian sources claim that Karabakh was part of a great Armenian kingdom as far back as the fourth century Before Christ. Nevertheless, the area of present-day Azerbaijan, known as ancient Media, was invaded by Persians in the $6^{\text {th }}$ century BC, by Alexander the Great in the fourth, and

1 For an overview of the historical controversies, see also Stephen H. Astourian, "In Search of Their Forefathers: National Identity and the Historiography and Politics of Armenian and Azerbaijani Athnogeneses", in Donald D. Schwartz and Razmik Panossian, Nationalism and History: The Politics of State-Building in PostSoviet Armenia, Azerbaijan and Georgia, Toronto: University of Toronto Press, 1994. 
by Romans in the First. ${ }^{2}$ However the area was at a very early stage aligned with the kingdoms lying at the East, that is what came to be Azeri-populated areas. According to the Greek Historian Strabo and Armenian chronicles, the population of present-day Azerbaijan was until the fifth century divided between a western third populated by Armenians who to their East had the Caucasian Albanians (unrelated to the Balkan Albanians) from which the Azeris claim descent. ${ }^{3}$ The Caucasian Albanian state emerged in the first half of the first Millennium, and occupied an area between Kartvelia (Georgia) in the West, the Caspian in the east, the Caucasus mountains in the North, and the river Araxes in the South. Hence its territory conforms roughly to present-day Azerbaijan. Caucasian Albania was basically a vassal of Sassanid Persia, and survived until the ninth century AD.

The time of the arrival of Turkic tribes from Central Asia is debated. Nevertheless it seems clear that by the eleventh century, the region had acquired a considerable Turkic population, which arrived with the Seljuk invasion and blended with the indigenous population. ${ }^{4}$ Nevertheless, Azeri historians claim the Turkish element of population was strong already in the seventh century AD, citing various contemporary but controversial sources. According to Peter Golden, one can speak of 'genuine interaction between the Turkic peoples and the populations of Transcaucasia' since the fourth century AD, in the shape of the Huns. ${ }^{5}$ The seventh century was the scene of a major event, the invasion of the Arabs and their settlement in Albania. This event led to the Islamicization of the majority of the Albanians; those that remained Christian are said to have orbited towards Armenia. The conversion to Islam also made the blending of the Albanians with the Seljuk Turks easier.

In the beginning of the sixteenth century, Azerbaijan became the native power base of the Safavid dynasty which came to rule Persia. This time was also the time of confrontation between the Safavids and the Ottoman empire, which naturally had an important direct effect on the Caucasus. In the beginning of the eighteenth century, Russia joined the struggle and by the 1840s Safavid rule had disintegrated in the Caucasus and today's Azerbaijan and Armenia were partitioned into Khanates, semi-independent principalities.

As far as High Karabakh is concerned, until the fourteenth century, it switched between Arab, Mongol, Turkic and Persian control. ${ }^{6}$ However the population of the area remained largely Armenian. In the fourteenth century, a local Armenian leadership emerged, and the Safavid Empire granted a form of autonomy to Karabakh. This arrangement lasted for almost four centuries, and a small number of influential families emerged in Karabakh, leading to conflicts of power among them. In the middle of the eighteenth century, the internal conflicts between the

\footnotetext{
${ }^{2}$ For an overview of Azerbaijan's early history, see Audrey L. Altstadt, The Azerbaijani Turks: Power and Identity under Russian Rule, Stanford: Hoover Institution Press, 1992, pp. 1-14. See also the first volume of Istoriia Azerbaidzhana/Azärbaycan Tarixi, Baku: Academy of Sciences of Azerbaijan, 1958.

${ }^{3}$ See Khachig Tololyan, ”National Self-Determination and the Limits of Sovereignty: Armenia, Azerbaijan, and the Secession of Nagorno-Karabakh”, in Nationalism and Ethnic Politics, vol. 1 no 1, Spring 1995, pp. 86-110, where a useful overview of early history can be found.

${ }^{4}$ See Tadeusz Swietochowski, Russian Azerbaijan, 1905-1920 — the shaping of National Identity in a Muslim Community, Cambridge University Press, 1985, p. 1.

5 See Peter B. Golden, ”The Turkic Peoples and Caucasia”, in Ronald Grigor Suny (ed.) Transcaucasia, Nationalism and Social Change, Ann Arbor: University of Michigan Press, 1996 (revised edition), p. 45-46.

${ }^{6}$ See Suzanne Goldenberg, Pride of Small Nations: The Caucasus and the Post-Soviet Disorder, London: Zed, 1994, p. 158.
} 
ruling families destroyed the local Armenian elite. This led to the region slipping out of Armenian control, and an Azeri ruler managed to impose his rule and create a semi-independent dynastic rule, the Khanate of Karabakh, based in Shusha. Hence the Karabakh Khanate was comparable to the Khanates of Baku, Kuba, Sheki, Shirvan, Derbent, Nakhjivan, and Yerevan. All of these Khanates were ruled by Turkic Muslim families. The population components of these Khanates was mixed; in effect Armenians Turks, and other groups lived scattered in the entire area, hence with overlapping settlement patterns. It is significant that the Yerevan Khanate itself was an area with a notable Muslim majority in 1826, a situation which had been reversed already in $1832 .^{7}$

In the end of the eighteenth century, Russia’s expansion in the Caucasus reached Georgia and the Georgian Gubernia or protectorate was formed in 1801, confirming Georgia's annexation to Russia. Simultaneously the first Azeri areas were included into Russia, that is the Khanates of Kazakh and Shamshadil. In these first years of the nineteenth century, Russia tried to assert its influence over the Azerbaijani Khanates, and Karabakh was one of the first to accept Russian overlordship, ${ }^{8}$ although insurrections against Russian rule occurred and Russian control was all but stable.

Russian attempts to assert control over the region led to the conquests of a number of Khanates in 1806-09, and ultimately to the first Russo-Persian war of 1812-13. The treaty of Gulistan, which ended this war, in fact led to Karabakh officially passing from nominal Persian control to Russian rule.

Only about ten years later new insurrections took place in Karabakh and other Khanates, as the Khans or their descendants returned and tried to make use of the popular disaffection with Russian rule that they hoped could enable them to reclaim their respective thrones. These movements were supported by Iran, and thus the consequence was a second Russo-Persian war emanating in a new Persian defeat, institutionalized in the treaty of Turkmanchai of 1828. This was important as far as Karabakh is concerned since immediately after the treaty, Russia encouraged and organized a population exchange. Thus huge number of Armenians left Persian and Ottoman lands to settle in the Russian Caucasus, and respectively large numbers of Muslims left the South Caucasus for areas under Persian or Ottoman control. ${ }^{9}$ According to Russian census reports, the Armenian population in Karabakh represented 9\% of the total in 1823 (the remaining $91 \%$ being registered as 'Muslims'), 35\% in 1832, and a majority of 53\% in 1880. This shows the relative rapidity of the population exchange. The process accelerated after every Russo-Turkish war (1855-56 an 1877-78) as Russians saw the Azeris as generally unreliable and as potential allies to the Turks, given their ethno-linguistic affinities. By contrast, the Armenians were seen as Russia's natural allies in the region, devoted to the Czar, and reliable. In a sense, then, Armenians were favored by the authorities and even took up important positions in the administration of the region. Naturally, the opposite was true in the Ottoman Empire, where Armenians were seen as a potentially pro-Russian fifth column, leading to the massacres of 1890. Even before that, though, Armenians left Turkey whereas numerous Azeris, in particular Sunni Azeris, migrated from the

\footnotetext{
7 See George A. Bournoutian, "The Ethnic Composition and the Socio-Economic Condition of Eastern Armenia in the First Half of the Nineteenth Century”, in Suny (ed.) Transcaucasia, op. cit. [5], pp. 78-79.

${ }^{8}$ See Tadeusz Swietochowski, Russia and Azerbaijan-A Borderland In Transition, New York: Columbia University Press, 1995, p. 8.

${ }^{9}$ An interesting fact is that Sunni Azeris tended to migrate to the Ottoman empire (a movement which initiated long before the Russian involvement) whereas Shi'ite Azeris moved towards Shi'ite Persia.
} 
Caucasus to the Ottoman Empire. By the turn of the century, there were over 1'200'000 Armenians in the South Caucasus, in what is called 'Eastern Armenia' to contrast with 'Western Armenia' which is located in modern-day Turkey. The Armenian population in the Western part is debated; Turkish sources speak of less than a million whereas Armenian sources often mention several million Armenians.

In the latter part of the nineteenth century, the Baku oil boom led to a concentration of Armenians in Baku, occupying the higher industrial and managerial positions. ${ }^{10}$ As the Armenians were clearly favorized by the Russian rulers in terms of their benefiting from the oil riches, tensions with the natives arose, whereas the two populations had been able to live in peace earlier in spite of the population exchanges and the fact that Armenians had made use of the practice to buy out Azeris from their lands, a practice which could have been seen as leading to tensions.

These tensions remained covert until the first Russian revolution of 1905, which soon spread to the South Caucasus. Disturbances broke out in Baku first but soon spread to Shusha in Western Karabakh, where the first inter-ethnic riots erupted. It is still disputed how the clashes started. According to Erich Feigl, the Dashnaktsutiun (The Armenian Revolutionary Federation) were very active in this period and terrorized the Azeri majority in Shusha, leading to the eruption of violence. ${ }^{11}$ Armenian or pro-Armenian sources ${ }^{12}$ such as Christopher Walker, on the other hand, argue that the Azeris (which he terms Tatars) provoked the fighting, leading to a strong Armenian response and eventually what he terms 'the victory of the Armenians'. ${ }^{13}$ Whatever the case, there were clashes all over Azerbaijan, notably in Baku, Ganja, Nakhjivan as well as in Yerevan. According to Feigl, over 10’000 Azeris were killed during this period, and high officials in the Russian provincial government were assassinated by the Dashnaks, including the Russian governor Nahagidze. ${ }^{14}$ Basically, it was a time of terror.

Following the Russian revolutions of 1917, the short-lived Transcaucasian Federation was born, as the leading political groupings (that is the Georgian Mensheviks, the Azerbaijani Musavat party, and the Dashnaks) of the time agreed to form a federal government for South Caucasia. The South Caucasus became in most matters completely separated from Russia, and finally declared independence on 22 April $1918 .{ }^{15}$ However it soon proved to be impossible to reconcile the three South Caucasian peoples, notably as the Armenians were interested in either a

\footnotetext{
${ }^{10}$ In this respect the role of Armenians in Baku, or in Istanbul for that matter, can be compared to the Jews in Eastern Europe, the Indians in East Africa, or the Lebanese in West Africa. These population groups all form hard-working and intelligent communities, which are characterized by internal cohesion and mutual support, which nevertheless live in isolation from the natives, from which they are distinguished in terms of language, ethnicity as well as religion. As these groups come to dominate business life, the tensions with the native population increase, as the latter see them as greedy, exploiting people, who help each other but whose behaviour is alien to the local customs and traditions.

${ }^{11}$ See Erich Feigl, Un Mythe de la Terreur-Le Terrorisme Arménien, ses Origines et ses Causes, Salzburg: Druckhaus Nonntal, 1991.

12 See Claude Mutafian, "Karabagh in the Twentieth Century”, in Levon Chorbajian, Patrick Donabedian and Claude Mutafian, The Caucasian Knot - the History and Geo-Politics of Nagorno-Karabagh, London: Zed, 1994, pp. 112-113.

${ }^{13}$ See Walker, Christopher, Armenia and Karabagh-The Struggle for Unity, London: Minority Rights Group, 1991.

${ }^{14}$ Feigl, Un Mythe de la Terreur, op. cit. [14], p. 215.

${ }^{15}$ For a detailed overview of the period, see Haidar Bammate, "The Caucasus and the Russian Revolution (from a political viewpoint)”, in Central Asian Survey, no. 1-2, 1991. (Article first published in Paris in 1929)
} 
British or a Russian protectorate and the Georgians were favorably disposed towards German rule. At this point, the Bolsheviks were interested in the Baku oil fields, and thus the Armenians played perfectly in Lenin's game. In May of 1918 already, the Azerbaijani and Georgian Democratic Republics (AzDR and GDR) were declared, and soon enough an Armenian Democratic Republic (The ArDR) was proclaimed in Tbilisi, although at the time it had no territory. Towards the end of May, the AzDR yielded the Yerevan region to the ArDR. Meanwhile the Dashnaks moved to chase Muslim population out of the Nakhjivan, Karabakh and Yerevan regions which they saw as historically Armenian. Azerbaijan proclaimed its independence under Ottoman protection, and was forced to locate the capital temporarily at Ganja as Baku was in the hands of the Bolsheviks (the Baku Commune).

Georgia became a sort of German military protectorate; and the Ottoman armies entered the Caucasus in the closing days of the First World War, which led to Ottoman armies and local Azeris initiating pogroms on Armenians, and clashes went on in Karabakh between the Dashnaks and the Ottoman army, supported by local Azeris. Again opinions differ regarding the origins of the clashes. Without going into detail, it as a whole seems safe to agree with Tadeusz Swietochowski's assessment that "massive eruptions of violence in the form of mutual intercommunal massacres began with the 1905 Russian Revolution, and would reemerge each time the Russian state was in a condition of crisis or overhaul—during the civil war in 1918 and during the perestroika from 1988 on”. ${ }^{16}$

Nevertheless, the British who replaced the Ottomans after their withdrawal reaffirmed Karabakh's belonging to Azerbaijan, by appointing a Muslim governor in Shusha. This led to protests among the local Armenians, who only reluctantly accepted Azerbaijani jurisdiction in February of 1920. Meanwhile guerrilla fighting went on, especially in the mountains, as the Dashnaks never accepted this arrangement. ${ }^{17}$ British policy in South Caucasia seems to have been characterized by short-sightedness and a total disdain for the interests and future of the Caucasian peoples. Britain's main interest seems to have been to prevent Bolshevik, or even other Socialist forces such as the Georgian Mensheviks from acceding to powers; South Caucasia would return to Russian rule once the White armies had defeated the Bolsheviks. The background to the seemingly pro-Azeri positions or rather anti-Armenian position taken by the British on the question of Nagorno-Karabakh can be deducted from the condescending attitudes the British often had regarding Middle Eastern peoples. As is outlined by Artin Arslanian, the British had only contempt for Armenians and Georgians, just like they had for Arabs, Jews, and Christians alike all over the Middle East. The one exception was the Turks. Due to their long history of administrating Ottoman territories, the Turks enjoyed a certain level of respect in British eyes as 'brave and clean fighting Turks', despite their 'uncivilized' behaviour. As Arslanian quotes General George Milne, responsible for British military operations in South Caucasia,

\footnotetext{
16 Tadeusz Swietochowski, “The Problem of Nagorno-Karabakh: Geography versus Demography under Colonialism and in Decolonization”, in Hafeez Malik, ed., Central Asia, Basingstoke: MacMillan, 1994, pp. 143-158, here at p. 145.

17 For an Armenian view of the British policies, see Mutafian, "Karabagh in the Twentieth Century”, op. cit. [12], pp. 118-124. See also Altstadt, The Azerbaijani Turks, op. cit. [2], 91-96.
} 
They [the local nationalities] are certainly not worth the life of one British soldier. The Georgians are merely disguised Bolsheviks ... The Armenians are what the Armenians have always been, a despicable race. The best are the inhabitants of Azerbaijan, though they are in reality uncivilized. ${ }^{18}$

It therefore does not seem far-fetched that the awarding of Nagorno-Karabakh to Azerbaijan, while intended only as a temporary phenomenon, was caused by British condescension for Armenians.

In the following years, three separate republics existed, but turmoil continued, mainly as the Dashnaks pursued their irredentist claims on their neighbours. They had territorial claims on both Georgia (the Akhalkalaki and Gocharli regions which are still today predominantly Armenianpopulated) and Azerbaijan (Karabakh, Zangezur, and Nakhjivan). Thus far from being peaceful, this era was characterized by inter-ethnic strife. By 1919, however, the Dashnaks were driven out of Nakhjivan, and although they stayed in power in Zangezur until 1921, they were soon toppled in Yerevan as well.

The first republic to be Sovietized was nevertheless Azerbaijan, probably due to the priority given by the Bolsheviks to secure the oil fields, and to the fact that Azerbaijan was the only republic in the South Caucasus where there existed a widespread support for the Bolsheviks, notably among the workers of Baku. ${ }^{19}$ Thus the Red army entered Baku in April 1920, as the Azerbaijani army was locked up in Karabakh fighting an Armenian uprising, and Azerbaijan became the first Soviet stronghold in South Caucasia. In November, Soviet power was established in Yerevan, sacking the Dashnaks, and the Red army proceeded to secure control over the whole of South Caucasia, with Georgia reconquered, as last of the three states, in April of $1921 .{ }^{20}$

\section{The Soviet era and the Suppression of the Conflict: 1921-1987}

At this point, the political struggle for Karabakh began, and would last long, as it took the Soviet leadership three years to settle the issue. Initially the pendulum seemed to swing in favour of Armenia, as the revolutionary committee of Soviet Azerbaijan in December 1920 under Soviet pressure from central authorities issued a statement that Karabakh, Zangezur and Nakhjivan were all transferred to Armenian control. Stalin (then commissar for nationalities) made the decision public on December 2, but the Azerbaijani leader Narimanov later denied the transfer. Four months later, the pendulum swung back. The 'Treaty of Brotherhood and Friendship' between the Soviet Union and republican Turkey included a provision that both Nakhjivan and Karabakh were to be placed under the control of the Azerbaijani SSR. It seems as if this was a concession on the part of Stalin to the newly founded Turkish republic in Ankara; Stalin was initially positively inclined to Kemal Atatürk, whom he saw as a potential ally at the time. Thus Atatürk was hostile to any territorial arrangements favoring Soviet Armenia, since a strong Armenia could have potential territorial claims on Turkey. Even given Stalin's tendency to divide the Caucasian

\footnotetext{
18 See Artin H. Arslanian, "Britain and the Transcaucasian Nationalities During the Russian Civil War”, in Suny, Transcaucasia, op. cit. [5], p. 303, citing Milne's letter to Wilson on 22 January 1919, in Papers of Field Marshal Sir Henry Wilson, Imperial War Museum, DS/Misc/80, File 37 no. 5.

${ }^{19}$ See Suny, Ronald G., The Revenge of the Past, Stanford University Press, 1993, p. 96.

${ }^{20}$ See Audrey L. Altstadt, “Nagorno Karabakh-'Apple of Discord' in the Azerbaijani SSR”, in Central Asian Survey, nr. 4, 1988.
} 
peoples to prevent unified resistance, ${ }^{21}$ the idea of separating the Armenians into two entities - the Armenian republic and Nagorno Karabakh-must have been welcome. Furthermore, by this decision not only the Armenians were divided but also the Azeris, into the Azerbaijani republic and Nakhjivan.

However, the game was not over yet. On 4 July, a meeting of the Kavburo, (Caucasian section of the Soviet communist party) voted in Stalin's presence to include Karabakh in the Armenian SSR. $^{22}$ The very next day, Narimanov protested against this decision and the Kavburo once again reversed its decision, and agreed to Karabakh's remaining in the Azerbaijani SSR, although the region was to be granted substantial autonomy.

During 1922, while unrest was still reported in Karabakh, discussions took place as to what the status of Karabakh would be within the Azerbaijani SSR. Finally, a decision was taken to give the region the rank of an autonomous Oblast, (the Oblast included the mountainous part of Karabakh and consequently was called the Nagorno Karabakh Autonomous Oblast, hereafter the NKAO) and a decree from Baku on 7 July 1923 established this state of affairs. A month later, the capital of the Nagorno-Karabakh Autonomous Oblast was moved from Shusha to Khankendï, not ten kilometers to the East, and the city was renamed Stepanakert, after Stefan Schaumian, the 'great Armenian Bolshevik' of the Baku commune. The NKAO was officially proclaimed in November 1924. Interestingly, a 1926 map in the first volume of the Great Soviet Encyclopedia had the NKAO touching upon Armenia at one point; however, one of the border changes of the Oblast that were made evidently cut the region of from the Armenian republic, and by 1930 maps had been adjusted accordingly, leaving the Lachin corridor under sovereign Azerbaijani territory, separating the NKAO from Armenia proper. ${ }^{23}$

In 1924, Nakhjivan received the status of an Autonomous Republic (ASSR) within the Azerbaijani SSR, despite the fact that the region had no land connection with mainland Azerbaijan. Nakhjivan's belonging to the Azerbaijani republic was actually decided at the same time as the discussions on Nagorno-Karabakh. Nakhjivan's status was, it seems, decided in talks between Soviet Russia and Kemalist Turkey, without involving any Armenians, at the treaty of Moscow in March 1921. This treaty stipulated that Nakhjivan would remain an autonomous region of Azerbaijan, and that the region's status could not be altered without Turkey's explicit approval. ${ }^{24}$ It is clear that this deal was clinched by Turkey in view of Ankara's military offensive in the Caucasus immediately following the Ottoman signing of the Sèvres treaty in August 1920. Turkey, aware of Soviet Russia's need for allies in the time of the civil war, successfully buried the Armenian question by the treaty of Moscow, followed by the treaty of Kars of 13 October

\footnotetext{
${ }^{21}$ This policy of Stalin's is clear if one observes the national delimitations in the Caucasus. An example is the regions of Karachai-Cherkessia and Kabardino-Balkaria. It seems, indeed, as the delimitation is designed purely to cause dissent in the regions that would enable Russia to control the regions. Karachais and Balkars are in fact in most respects one people speaking the same Turkic language; similarly Kabardins and Cherkess are both Circassian peoples. Thus the result of the national delimitation is that both regions include two titular nationalities without ethno-linguistic affinities, which have mutual prejudices and historical antagonisms against each other. For an overview of the subject, see Pustilnik, Marina, “Caucasian Stresses”, in Transition, 15 March 1995, pp. 16-18, or Smeets, Rieks, "Circassia”, in Central Asian Survey, nr. 1, 1995.

${ }^{22}$ See Goldenberg, Pride of Small Nations, op. cit. [6] p. 159, or Robert Cullen, “A Reporter at Large”, in The New Yorker, 15 April 1991.

23 See Altstadt, The Azerbaijani Turks, op. cit. [2], p. 127.

24 See Mutafian, ”Karabagh in the Twentieth Century”, op. cit. [12], p. 134.
} 
1921 between Turkey and the three South Caucasian republics, which in principle was a ratification of the Moscow treaty by the three republics. There is a point in Richard Hovannisian's statement that 'Soviet Russia, on the international front, sacrificed the Armenian question to cement the Turkish Alliance'. ${ }^{25}$ Thus in the end it seems clear that the Armenians in this particular instance were disfavored by the Soviets. This is in a sense surprising, given that the Armenians had historically been far more benevolently disposed towards - as well as favored by - Russian rulers than the Azeris. In retrospect, this decision may have been to Azerbaijan's immediate favour, but in the long run the Armenians' feeling of frustration with the loss of western Armenia despite western promises, and the loss of Nagorno-Karabakh and Nakhjivan, despite Soviet promises, proved to be a catalyzer of conflict.

The Armenians were naturally disappointed with this situation, especially given the fact that they had been promised Karabakh by the Soviets at earlier stages. Furthermore, parallel events in the early 1920s must be mentioned to elucidate the entirety of the Armenian question. In August 1920 the treaty of Sèvres was signed, in which Woodrow Wilson himself had drawn the boundaries of a future Armenian state. This state was designed to include portions of Eastern Anatolia, or what Armenians call Western Armenia. Moreover, it was designed to include Nakhjivan—despite its predominantly Turkic population—as well as most of the NKAO. ${ }^{26}$

Thus once under Soviet rule it became the persistent aim of Armenian elites to reverse the situation and persuade Moscow to turn Karabakh over to the Armenian SSR. It has to be noted, at this point, that the Soviet decision was actually quite arbitrary in several ways. First of all, Nakhjivan received the status of an ASSR, and there is no reason why Nagorno Karabakh should not have been eligible for the same status. And in fact, an arrangement were the status of these two regions would have paralleled each other (such as a Nakhjivan ASSR under the Azerbaijani SSR, and a Nagorno Karabakh ASSR under the Armenian SSR) would indeed have been more logically persuasive and prevented rather than catalyzed future conflict. Against this claim, the Azeris advance the fact that there are sizable Azeri minorities in Armenia, Georgia as well as in Dagestan (especially in the Derbent region) which did not receive any autonomous status at all although geographically these populations are geographically concentrated in certain areas. Especially the loss of Derbent is inexplicable to the Azeris, who claim that it in this context it was not evident that the Armenians in Karabakh would even receive an Autonomous status at all. Nakhjivan is not encircled by Armenia, as Nagorno Karabakh is encircled by Azerbaijan: Nakhjivan has a border with Turkey (if only seven kilometers) as well as Iran. One might argue, moreover, that Nakhjivan is an integral part of Azerbaijan, its autonomous status being derived only from the fact that it is geographically separated from mainland Azerbaijan, as Kaliningrad was separated from the RSFSR. In any case, both Nagorno-Karabakh and Nakhjivan were exceptions in the Soviet system of federalism: There is no other case of an Autonomous region or republic whose titular nationality is the same as the central state's titular nationality, as is the case in Nakhjivan. Neither is there a case of a national group which was endowed with both a union republic and an autonomous region or republic in another union republic, as was NagornoKarabakh's case. In general, only indigenous groups without a mother nation in another, Soviet or non-Soviet territory, were given autonomous status. The only other example of a nation with two

25 See Richard G. Hovannisian, "Caucasian Armenia between Imperial and Soviet Rule: The Interlude of National Independence”, in Suny, Transcaucasia, op. cit. [5], p. 293.

${ }^{26}$ See Tololyan, ”National Self-Determination”, op. cit. [3], p. 91. 
political entities are the Ossetians, with an Autonomous Republic in Russia and an Autonomous Region in Georgia. National minorities living outside of their national republic were normally not eligible for autonomous status. Systematic implementation of such a principle would have been impossible in practice as well, as the list of minorities on 'the wrong side of the border' would be long. One only has to cite a few examples: Tajiks in Uzbekistan, Uzbeks in Tajikistan, Russians in Ukraine, Russians in Kazakhstan, Armenians and Azeris in Georgia, etc. Hence the peculiar construction that emerged out of perceived necessity in the Caucasus can in itself be termed a source of conflict. ${ }^{27}$

Whatever conclusion can be drawn from the territorial delimitation, the Armenians already in the 1930s attempted to regain control over both Nagorno Karabakh and Nakhjivan, at a time when a number of territories saw their status changed from above, such as Abkhazia's relation to Georgia. Indeed, changing the status of a territory was not an alien event to the Soviet leadership-consider Crimea's 1954 transfer from Russia to Ukraine. However, the Armenians found no support from the center. In 1936, the dissolution of the Transcaucasian Federative Socialist Soviet Republic, including the three South Caucasian republics, led to the further distancing of Nagorno-Karabakh from Armenia; the only administrative contact between the two was now their common appartenance to the Soviet Union. Naturally, internal borders in the Soviet Union carried little significance; Karabakh Armenians seeking higher education could do so either in Baku or in Yerevan; the contacts with Armenia lived on. The Armenian leader of the time raised the Karabakh issue to the dismay of Stalin, only to be assassinated in $1936 .{ }^{28}$ Whether he was killed because of these demands or met the fate of so many other people for arbitrary reasons is nevertheless unclear.

In 1963, with the more open climate created by Krushchev's destalinization, a petition signed by approximately 2’500 Karabakh Armenians was submitted to Krushchev, protesting the Azeri attitude towards the region and claiming the Azeris were intentionally neglecting the NagornoKarabakh Autonomous Oblast economically. Moscow kept its silence, acted as if nothing had happened, and unrest erupted in Karabakh, leaving 18 casualties. Tensions broke out in 1968 as well. $^{29}$ In 1970, a census recorded 80\% Armenians in Karabakh, whereas in 1939 they had composed 91\% of the population. The Armenians blamed the change on the Azerbaijani government, claiming that the Azeris intentionally tried to manipulate the population of the region. Following this, the Armenian republic's leadership became more vocal on the Karabakh issue and voiced their demands frequently at Union meetings. Thus the tensions remained during the whole Soviet era, still simmering but with small sporadic eruptions. All attempts to campaign

\footnotetext{
27 For an overview of Autonomous territories in the former Soviet union, see Svante E. Cornell, ”Autonomous Territories in the Former Soviet Union: Transition and Prospects for Peace and Conflict”, forthcoming working paper, Department of East European Studies, Uppsala University..

28 See Mutafian, ”Karabagh in the Twentieth Century”, op. cit. [12], p. 145.

29 Ibid., p. 146.
} 
for the unification of Karabakh and Armenia were branded as retrograde nationalist propaganda and suppressed. 


\section{2 \\ Escalation: 1987-91}

It was not until Glasnost in the late 1980s that the situation would change as it was safer to express demands in the new, more open atmosphere in the Soviet Union. Thus the number of sporadic incidents grew quickly from 1987 onwards, letters demanding unification started flowing in to the Moscow authorities. In August of 1987, a petition prepared by the Armenian academy of sciences with hundreds of thousand signatures (in Armenia) asked for the transfer of Nagorno Karabakh and Nakhjivan (where a 1979 census had recorded over $97 \%$ Azeris $^{30}$ ) to the Armenian SSR. $^{31}$

\section{Perestroika and the Re-Emergence of the Conflict: 1987-91}

In October, Armenians refused to accept the nomination of an Azeri Sovkhoz director in the predominantly Armenian village of Chardaklï in Northwestern Azerbaijan. This led to a crackdown by the local party organs on villagers. ${ }^{32}$ According to Armenian sources, the objective of the local (Azerbaijani) party organs would have been to drive out the Armenian population. ${ }^{33}$ The news of Chardaklï promptly reached Yerevan where demonstration asking for the closure of polluting industries were going on. Following a quite common trend of the Glasnost period, the ecological demonstrations quickly transformed into political, nationalist demonstrations asking for the return of Nagorno Karabakh and Nakhjivan to Armenia. This time the local police intervened to dissolve the demonstration. ${ }^{34}$ As Moscow refrained from taking action, speculations went on that Moscow would approve of the transfer, especially given the fact that Gorbachev had a number of high advisors of Armenian origin. In the middle of November 1987, an economic advisor of Gorbachev's, Abel Aganbeyan, told the French newspaper L'Humanite that the NKAO would soon be transferred to Armenia. ${ }^{35}$ The importance of this declaration, when relayed back to Armenia, is easy to imagine.

\footnotetext{
${ }^{30}$ For an overview of the population distribution of Nagorno Karabakh and Nakichevan between 1959 and 1979 , see Alexandre Bennigsen and S. Enders Wimbush, Muslims of the Soviet Empire-A Guide. London: Hurst \& Co., 1985.

${ }^{31}$ See Gerard Libaridian, The Karabagh File, Cambridge, MA: Zoryan Inst., 1988, pp. 83-88.

32 See Claire Mouradian, "The Mountainous Karabakh Question: Inter-Ethnic Conflict or Decolonization Crisis”, in Armenian Review, vol. 43 no. 2-3, 1990, p. 15.

33 See Mutafian, ”Karabagh in the Twentieth Century”, op. cit. [12], p. 144.

34 See Elizabeth Fuller, "Armenians Demonstrate for Return of Territories from Azerbaijan”, in Radio Liberty Research Bulletin, 20 October 1987, p. 1.

35 See L'Humanité, 18 November 1987. See also discussion of this declaration's importance in Arie Vaserman and Rami Ginat, ”National, Territorial or Religious Conflict? The Case of Nagorno-Karabakh”, in Studies in Conflict and Terrorism, vol. 17 no. 4, 1994, pp. 345-362, here at p. 348.
} 
Gorbachev, according to his memoirs, was convinced of the inviolability of internal borders, although vaguely sympathetic to the Armenian cause. Subsequently, he had become in favour of granting Nagorno-Karabakh ASSR status, to parallel it with Nakhjivan. This indeed seems to be have been a solution that might have defused tensions at an early stage, reaching a compromise while safeguarding the territorial integrity of Azerbaijan. Nevertheless, Gorbachev endorsed this idea only in 1989, in his own words,

There was a time when this proposal was on the point of being implemented. However, it was just at this moment that the Supreme Soviet in Yerevan passed a resolution to incorporate NagornoKarabakh as part of Armenia and so everything fell apart. It fell apart because of internal antagonism, because the battle for power, for replacement of the ruling elite, was already in full swing there. If fell apart because the Armenian national movement, which was formed on the basis of the Karabakh committee, was in a hurry to seize power. ${ }^{36}$

The idea, then, might have been a good one if imposed earlier on. At that moment, however, it is highly unlikely that either of the parties to the conflict would have accepted it; indeed, it is uncertain whether the implementation of such a decision would at all have hindered the eruption of the conflict.

\section{February 1988: The Explosion}

Following the Chardaklï events, the Azeris in Armenia faced increasing difficulties and harassment, as Armenians started driving Azeris out of Armenia. In the end of January of 1988 the first refugee wave reached Baku, and most refugees were relocated in Sumgait, in Baku's industrial suburbs. Before the end of February, two more waves of refugees were to reach Baku. Demands for Karabakh's unification with Armenia multiplied, and on 10 February the Azerbaijani Information Agency declared Azerbaijan would never agree to such demands. ${ }^{37}$ On 11 February demonstration in Karabakh protested the cultural and economic policies of the Baku government towards the Nagorno-Karabakh Autonomous Oblast, and on 20 February the Soviet of the Oblast passed a resolution (with 110 for and 17 against) appealing to the Supreme Soviets of Armenia, Azerbaijan, and the USSR to be transferred to the Armenian SSR's control. ${ }^{38}$ Amazingly enough, the Azerbaijani party leader, Kamran Bagirov, was present at the meeting but unable to stop the resolution. Neither was he able to stop the ousting of the NKAO's loyal party leader, Boris Kevorkov, by an outspoken nationalist, Henrik Pogosyan. ${ }^{39}$

On 22 February candidate politburo member Georgi Razumovsky appeared in Stepanakert, speaking to the local party organization. ${ }^{40}$ The next day, Vladimir Dolgikh, another candidate member of the Politburo, spoke to the Armenian party meetings, and on the $24^{\text {th }}$ Razumovsky had

\footnotetext{
${ }^{36}$ For Gorbachev's account of the eruption of the conflict, see Mikhail Gorbachev, ”The Karabakh Explosion”, in Memoirs, New York \& London: Doubleday, 1996, pp. 333-340.

37 See Niall Fraser et. Al., "A Conflict Analysis of the Armenian-Azerbaijani Dispute”, in Journal of Conflict Resolution, vol. 34 no. 4, December 1990, pp. 652-677, here at p. 658.

38 See, eg., Paul Quinn-Judge, ” Gorbachev treads fine line on Armenian issue. Soviet leader's conciliatory line may fuel more nationalism, but crackdown would stymie reform”, in The Christian Science Monitor, 29 February 1988, p. 10.

${ }^{39}$ See Bakinsky Rabochy, 24 February 1988, p. 2.

${ }^{40}$ See Bakinsky Rabochy, 23 February 1988, p. 2.
} 
travelled to Baku for similar purposes. ${ }^{41}$ Hence it would be wrong to say that the central organs of the communist party ignored the conflict. Quite to the contrary, they were at a very early stage present at its three centers, before violence actually broke out. However, the information the emissaries provided to the media were confusing. Dolgikh, for one, was reported to have stated that "in Nagorno-Karabakh, things have gone as far as clashes between groups of Armenians and Azerbaidzhanis, and there have been casualties." ${ }^{22}$ On the other hand, USSR deputy prosecutor general Katusev, in Stepanakert, claimed the next day claimed that "none of the ... rumors ... have any base in fact; not one person ... has been killed." 43 This statement was confirmed by a first deputy minister of interior on 25 February. ${ }^{44}$ The question is, then, if the emissaries' information sources were so poor or confusing that they ended up providing contradictory information—or if they intentionally tried to blur the picture of the events. The latter case's likelihood is intimately related to the question of the Kremlin's interests in the Caucasus. Did the leadership of the union have any interest in letting the conflict escalate instead of stopping it? According to certain observers, notably in the Caucasus, the Kremlin at this time felt a fear that the Caucasus, as well as the Baltics, were escaping central control. Following this line of reasoning, the authorities in Moscow would hence have resorted to traditional divide and rule policies in order to regain control over the region. This would involve letting Azerbaijan an Armenia concentrate on their mutual enmity in order to avoid a quest for further autonomy. Likewise, South Ossetian and Abkhazian claims in Georgia were encouraged to curb Georgian secessionism. This argument is naturally controversial and displays several flaws. Most importantly, an active policy of destabilizing the Caucasus must at this point have seemed very dangerous and the risk of its back-firing must have been considered as substantial by anyone. Instead of enabling Moscow to reassert its control over the region, it could very easily lead to the exact opposite. Moreover, Soviet policy would arguably have been more likely to resort to brute force to curb any form of unrest than articulating an elaborate plan to use it to its benefits.

Notwithstanding the reports of the politburo's emissaries, it seems clear that between 21 and 25 February, tensions in Armenia escalated as ecological demonstrations in Yerevan once again turned to irredentism. A 'Karabakh Committee' was formed, and the Armenian Diaspora in the West inflated the numbers of demonstrators, talking about 'one million people on the streets of Yerevan', in a country whose entire population is three million. The Armenian spiritual leader, the Catholicos, joined the demands on 25 February, requesting Gorbachev to respect the NKAO Soviet's decision. Gorbachev then met with two leaders of the Karabakh Committee in Moscow, Zori Balayan and Silvia Kaputikyan, on 26 February, and asked for a one-month moratorium on demonstrations in order to assess the issue. ${ }^{45}$ However, when Kaputikiyan returned to Yerevan the same evening she told the crowd 'the Armenians have triumphed', despite the fact that Gorbachev

\footnotetext{
41 See Kommunist (Yerevan), 24 February 1988, p. 2; and Bakinsky Rabochy, 25 February 1988, p. 1, translations available in Current Digest of the Soviet Press, vol. XL no. 8, 1988, p. 4.

${ }^{42}$ Kommunist (Yerevan), 25 February 1988, p. 1, translation available in Current Digest of the Soviet Press, vol. XL no. 8, 1988, p. 5.

43 See Pravda, 26 February 1988, p. 2.

44 Kommunist, 26 February 1988, p. 1, translation available in Current Digest of the Soviet Press, vol. XL no. 8, 1988, p. 5.

${ }^{45}$ See Libaridian, The Karabagh File, op. cit. [31], p. 87.
} 
made no promises of any kind. ${ }^{46}$ Later, she claimed in an interview to have meant that 'we triumphed morally. We Armenians are accustomed to drawing inspiration from defeats ... And that's what I had in mind. We triumphed morally'. ${ }^{47}$ The likelihood of this explanation can nevertheless be debated - in fact it appears to be an excuse for another attempt to pressure Moscow by announcing a victory.

Simultaneously, in Karabakh the situation was all but calm. In fact, the atmosphere in Stepanakert was militant. Rumours told that Moscow was 'almost ready to say "yes"', that is, to accept a transfer, and all that the Karabakh Armenians had to do now was 'to voice the demands more resolutely'. ${ }^{48}$ Izvestiya correspondents were informed that Karabakh's transfer to Armenia was far beyond any 'arithmetic' calculations of economic benefits, but a 'sacred cause'; furthermore leaders of Krunk, Stepanakert's Karabakh committee, predicted that 'a guerrilla war will begin'. ${ }^{49}$ Such views seemed to be shared not only by the leading clique, but judging from the number of signatories to petitions and the participation noted in demonstrations also among Karabakh's Armenian majority. Hence, as Stuart Kaufman notes, 'popular attitudes seem to have been ripe for the emergence of open elite outbidding'. ${ }^{50}$

\section{Sumgait: The Escalation Becomes Irrevocable}

The conflict was to erupt for real on 26 February, after rumours of violent riots in Stepanakert leading to the death of an Azeri reached Agdam, an Azeri city some miles away from Karabakh's eastern border. Demanding information on the events in Stepanakert, a crowd of Azeris nevertheless were told no such thing had occurred. Certain sources also claim Bagirov himself stopped in Agdam on his way to Karabakh, where he attended the supreme Soviet meeting where Pogosyan was nominated. ${ }^{51}$ In any case, Dissatisfied, they marched on Nagorno-Karabakh in several coumns. Apparently, some of the columns were halted by distinguished locals preaching restraint. ${ }^{52}$ However, equally apparently, some columns proceeded to Askeran in the border area between Azerbaijan proper and the NKAO, where it came to clashes between the crowd, Armenian villagers, and police units. The result was two dead Azeris, reportedly one killed by a stone and one by an Azerbaijani policeman, ${ }^{53}$ and an unknown number of wounded on all sides. ${ }^{54}$

On Azerbaijani Radio, deputy attorney general Katusev reported the fact that 'two inhabitants of the Agdam district fell victim to murder', giving to Muslim surnames. ${ }^{55}$ These news, according

\footnotetext{
46 See Gary Lee, "Gorbachev Reportedly Makes Pledge in Session with 2 Dissenters”, in The Washington Post, 28 February 1988, p. A30.

${ }^{47}$ See Cullen, “A Reporter at Large”, op. cit. [22], p. 66.

48 See S. Dardykin and R. Lynev in Izvestiya, 24 March 1988, p. 6, translation available in Current Digest of the Soviet Press, vol. XL no. 13, pp. 6-7.

49 Ibid.

50 See Stuart J. Kaufman, Ethnic Fears and Ethnic War in Karabakh, Paper presented at the International Studies Association meeting, Minneapolis, March 1998, p. 16.

51 The New York Times, 11 March 1988, p. A6.

52 See A. Afanasyev, D. Muratov, A. Mursaliyev, A. Sarkisian, in Komsomolskaya Pravda, 26 March 1988, p. 4, and 27 March 1988, p. 4.

53 See Cullen, “A Reporter at Large”, op. cit. [22], p. 66.

${ }^{54}$ See Elizabeth Fuller, ”Nagorno-Karabakh: The Death and Casualty Toll to Date”, in Radio Liberty Research Bulletin, 14 December 1988, p. 1.

${ }^{55}$ The New York Times, 11 March 1988, p. A6.
} 
to Tamara Dragadze, were announced to show the gravity of the conflict and to calm down sentiments. ${ }^{56}$ However, Igor Nolyain interprets the broadcast in a totally different light: As intended to escalate tensions by hinting at ethnically conditioned murder. ${ }^{57}$ Whatever the intention, the result was in conformity with the latter and as Stéphane Yérasimos states, the ethnic conflict followed its own logic. ${ }^{58}$ For what could be a more logical place for retaliatory violence than Sumgait, Baku's dark industrial suburb, where on top of everything huge numbers of furious and frustrated Azeri refugees have been resettled only days or weeks ago? Admittedly, this line of thought has severe flaws. The question would be: why Sumgait? Baku or Gence would actually have been more logical places for the eruption of violence.

On the $26^{\text {th }}$, agitation in any case began in Sumgait, activists demanding revenge against Armenians for the Azeri deaths in Askeran. The unrest did not take on an additional dimension until word spread that the Armenians had declared victory in Yerevan after meeting with Gorbachev. ${ }^{59}$ In any case the following three days were coloured by hooligans going on rampage, looting Armenian homes, burning houses and hunting for Armenians. he official figures show 32 dead (26 Armenians and 6 Azeris) for the three days, 27-29 February, that the unrest went on, although Armenian sources multiply the numbers of (Armenian) casualties by a factor of at least ten. ${ }^{60}$ The fact that the Soviet army and Interior ministry troops were in the area did not change anything; in fact the army seems to have stood by and watched the pogrom take place, According to Nolyain, the Soviet authorities not only failed in preventing bloodshed, but deliberately sought to create a conflict between the two communities, both in Armenia and in Azerbaijan. This was done through the control of the media, by spreading exaggerated and provocative statements on both sides, and by deploying criminals from Soviet prisons in Sumgait to initiate the pogrom.

As far as Sumgait is concerned, the origins of the pogrom remain, in Kaufman's words, mysterious. ${ }^{61}$ To assume that the unrest erupted out of suppressed frustrations and primordial ethnic hatred seems too simplistic a conclusion, ${ }^{62}$ fitting well into the official rhetoric that developed after the events, covering up the inability or unwillingness of authorities to prevent the events with reference to a 'protracted ethnic conflict', seemingly understood as a machine which could not be stopped even by the Soviet state. Nolyain's research shows that the Soviet militia, which has curbed riots or peaceful demonstrations with overkills of violence in numerous cases, became 'helpless' in Sumgait. ${ }^{63}$ Several sources noted that some kind of 'paralysis' gripped the Sumgait milita — highly uncommon for the reputedly so trigger-happy character of Soviet militias, or in Nolyain's words, their 'highly energetic manner, mutilating bystanders and strangling

\footnotetext{
56 See Tamara Dragadze, “The Armenian-Azerbaijani Conflict: Structure and Sentiment”, in Third World Quarterly, No. 1 (January) 1989, p. 56; or Dragadze, ”Azerbaijani and the Azerbaijanis”, in Graham Smith, (ed.), The Nationalities Question on the Post-Soviet states, New York: Longman, 1996.

${ }^{57}$ See Igor Nolyain, “Moscow’s Initiation of the Azeri-Armenian Conflict”, in Central Asian Survey, vol. 13 no. 4, 1994, p. 541-563, here at p. 542.

${ }^{58}$ See Stéphane Yérasimos’ excellent article “Caucase: Le Retour de la Russie”, in Politique Internationale, no. 1, 1994.

59 See Cullen, “A Reporter at Large”, op. cit. [22], p. 66.

60 See Mutafian, ”Karabagh in the Twentieth Century”, op. cit. [12], p. 150.

${ }^{61}$ Kaufman, Ethnic Fears and Ethnic War in Karabakh, op. cit. [50], p. 17.

${ }^{62}$ Yérasimos conclusions on the mixture of Sumgait's derisory atmosphere and the arrival of refugees are of this kind. “Caucase: Le Retour de la Russie”, op. cit. [58], p. 66.

${ }^{63}$ See Moscow News, 29 May-5 June 1988.
} 
reporters' ${ }^{64}$ It seems clear, then, that the reason for the militia's inaction was that they were simply given orders not to intervene. Especially given the fact that deputy interior minister Nikolai Demidov admits having been in Sumgait during the pogrom, this seems odd - to say the least. Did the militia fail to act because of 'paralysis' or because they had clear orders to do so? The circumstances surrounding the pogrom and the attitude of law enforcement agencies are at the very least suspicious. Interestingly, the press for several days reported only of violence on 28 February, whereas the violence obviously lasted for several days. ${ }^{65}$ Only by April did Soviet press refer to violence occurring on 27-29 April. ${ }^{66}$ However, the Sumgait unrest was taken under control only on 1 March. According to the Washington Post, 'Despite the heavy presence of armed militia, the protests and riots went largely undeterred until March 1, when troops and tanks were dispatched to Sumgait' ${ }^{67}$ Despite the apparent difficulty of getting troops to Sumgait, troops were flown in to Yerevan on 25 February - that is the day before Sumgait erupted-apparently only as preventive measures. This begs the question why troops could not be sent in to Sumgait as promptly as is the habit in cases of civil unrest in the Soviet Union.

Moreover, there are several instances of independent evidence which suggests that the riots were started by people coming from outside Sumgait. According to a Baku television reporter, 50 to 60 Azeris from Armenia came to Sumgait to speak of events in Armenia, leading to hot feelings in the crowd and ensuing hooliganism. ${ }^{68}$ According to a Washington Post reporter, 30 Azeris from the Armenian city of Gafan told a Baku rally of atrocities committed against Azeris there. As a result, youth from Baku went to Sumgait to start a protest. ${ }^{69}$ This information is perhaps the most illogical. If people came from Karabakh to Baku to spread unrest, why take the trouble of traveling to Sumgait? There were hundreds of thousands Armenians in Baku that were impeccable targets. The discussion on Sumgait is difficult to conclude; the event remains a mystery which does not make any logical sense. There was no mobilized Azeri ethnic nationalism to speak of on 26 February 1988; people in Azerbaijan had hardly begun to be affected by the events in Armenia; most Azeris were in fact shocked by the event. The assertion that outside forces were at play seem to make sense; it nevertheless remains difficult, if not impossible, to prove.

Whatever the real level and nature of Moscow's involvement, it seems clear in retrospect that much did not have to be done to set Armenia and Azerbaijan on fire. If the aim of certain forces in Moscow was, as is often argued, to destabilize the area by creating an inter-communal war which would weaken both governments and enable Moscow to reestablish control over the area, these forces were only wrong in the sense that they did not know what kind of a monster they were giving birth to. The Azeri-Armenian conflict soon slipped out of the Moscow's hands, and to day's date it has only partly led to a reassertion of Russian power in the South Caucasus, but on the other hand it has created a volatile situation which has at several instances threatened to become internationalized. In fact, mutual hatred had escalated to such a point that any spark

\footnotetext{
${ }^{64}$ See Nolyain, “Moscow’s Initiation of the Azeri-Armenian Conflict”, op. cit. [57], p. 546.

${ }^{65}$ Bakinsky Rabochy, 3 March 188, p. 1; Pravda, 22 March 1988, p. 6; Izvestiya, 23 March 1988, p. 2.

66 See Moskovskye Novosti, 17 April 1988, p. 13.

${ }^{67}$ Gary Lee, "Protests In Azerbaijan Planned To Coincide With Expected Decision Later This Week”, in The Washington Post, 21 March 1988, p. A15.

${ }^{68}$ Associated Press, 29 February 1988, citing Nolyain, "Moscow’s Initiation of the Azeri-Armenian Conflict", op. cit. [57], p. 549.

${ }^{69}$ Lee, ”Protests In Azerbaijan”, op. cit. [67].
} 
would have been capable of initiating the conflict. And the spark which would make the process of escalation of the ethnic conflict irreversible, was indeed the Sumgait pogrom. After Sumgait, there seemed to be no way to bring about a de-escalation of the conflict, and in any case this was made impossible by the wobbling and hesitant approach of the Soviet authorities.

To the Armenians, Sumgait was like a reminder of the massacres of the first world war and equated the Azeris with the Ottoman armies. It only made them more firm in their belief that there was no way they could live in any form of arrangement with the 'Barbarian Turks'. From this point onwards, Azeris were systematically chased from Armenia, notably from the Ararat and Zangezur regions where they lived in substantial numbers. The Armenian frustration was worsened when, on 10 March, Gorbachev hinted that a transfer would probably not be allowed. ${ }^{70}$ By 21 March, however, tensions reached a boiling point in Baku as a decision from Moscow was expected, Azeris fearing a transfer of Nagorno-Karabakh to Armenia. ${ }^{71}$ On 23 March, the presidium of the Supreme Soviet of the Soviet Union-that is the highest institution in the Union-rejected the demands of the Karabakh Soviet to be joined to Armenia without any possibility of appeal. ${ }^{72}$ Troops were deployed in Yerevan to prevent protests to the decision. In the following months, Azeris in Armenia were the subject of further harassment and were forced to flee. In the district of Ararat, four villages were burned on the $25^{\text {th }}$ of March. On 7 June, Azeris were evicted from the city of Manis near the Armenian-Turkish border, and on the $20^{\text {th }}$ of the same month five further Azeri villages were cleansed in the Ararat region. ${ }^{73}$ In Baku, especially, but all over Azerbaijan, ethnic rioting in June led to fear among the Armenian population, some of whom sought refuge in Armenia. Meanwhile, demonstrations in Nagorno-Karabakh, where many factories kept striking, as well as in Armenia continued. On 21 May, the republican leaders of Armenia and Azerbaijani were replaced, following unrest in both republics that had erupted after sentences had been laid down by a Baku court for the Sumgait events. ${ }^{74}$ Bagirov was replaced by Abdulrahman Vezirov, and Demirchian by Suren Arutyunyan, in an attempt by Moscow to take control over the situation. ${ }^{75}$

\section{The Spiral of Violence and the Militarization of the Conflict}

On 13 June, the Azerbaijani Supreme Soviet rejected the 20 February vote as unacceptable. ${ }^{76}$ Simultaneously, Armenian supplies to the NKAO through the Lachin corridor were subjected to attacks and roadblocks. ${ }^{77}$ On June 15, the Armenian Supreme Soviet answered by voting

\footnotetext{
${ }^{70}$ See The Washington Post, 10 March 1988, p. A37.

${ }^{71}$ See The Washington Post, 21 March 1988, p. A15, and 23 March 1988, p. A21

${ }^{72}$ The claim of the Karabakh Soviet was based upon Art. 70 of the Soviet constitution, which affirms the right of peoples to self-determination. However, the claim was rejected on the basis of Art. 78, which states that 'territory may be altered only by mutual agreement of the concerned republics, and subject to the ratification by the USSR. Thus the rejection of the demand by the Azerbaijani Supreme Soviet made proposition impossible according to Soviet law. The legal aspect of the issue is further discussed below.

73 See Arif Younoussov, ”Les Pogroms en Arménie en 1988-89”, Express-Khronika (Moscow), no. 9, 26 February 1991.

${ }^{74}$ See The Washington Post, 22 March 1988, p. A1.

75 See Pravda, 22 May 1988, p. 2, translation available in Current Digest of the Soviet Press, vol. XL no. 21, 1988, p. 17.

76 See Bakinsky Rabochy, 14 June 1988. Se also translation in Appendix 9 of Chorbajian et. al., The Caucasian Knot, op. cit. [12].

${ }^{77}$ See Mutafian, ”Karabagh in the Twentieth Century”, op. cit. [12], p. 152.
} 
unanimously for unification with Karabakh; ${ }^{78}$ two days later the Azerbaijani Supreme Soviet, equally unanimously, rejected the decision, and accused it of being a violation of the Soviet constitution and of Azerbaijan's territorial integrity. ${ }^{79}$ On 28 June, Gorbachev reaffirmed the inviolability of internal frontiers at the congress of the CPSU in Moscow. This statement, in particular, exacerbated the frustration of the Karabakh Armenians, who proceeded to unilaterally vote for secession on 12 July, seeing that nothing positive was to be expected from Moscow. ${ }^{80}$ On 18 July, the Presidium of the Supreme Soviet of the USSR declared the decision null and void, reaffirming Azerbaijan's territorial integrity. By this time, Moscow seemed increasingly irritated with Armenian nationalism and subtly moved closer to Baku's position, which it viewed as pro status quo and therefore in line with the interests of the center. On the same day, a 'special commission' was established by the authorities in Moscow to monitor the developments in the two republics. Arkadiy Volsky, a mechanical engineer who admitted not to have any understanding of 'national relations', was appointed head of the commission. ${ }^{81}$

After some months of relative calm, mass rallies erupted in Baku on 17 November, directed against the weakness of the Azerbaijani party leadership, which was seen as failing to assert republican control over the NKAO. ${ }^{82}$ The next day, a general strike took place in Armenia, in demand of the unification of unification with the NKAO. ${ }^{83}$ On 21 November, the USSR supreme court announced a death sentence to an Azeri for the Sumgait pogrom. ${ }^{84}$ Following this announcement, anti-Armenian pogroms took place the following days in Baku and Ganja, from where Armenians were expelled. ${ }^{85}$ A state of emergency was declared in Baku, Ganja and Nakhjivan on 26 November, ${ }^{86}$ and a curfew in Yerevan on the $25^{\text {th }}$. Later that month, the last Azeris were forced out of Armenia. The month of November was one of great refugee flows. According to unofficial sources, around 180’000 Armenians had left Azerbaijan, and 160’000 Azeris had left Armenia by the end of the month. Official Azerbaijani government sources reported 78'000 refugees from Armenia on 3 December, while the Yerevan military commander spoke of 31'000 Armenians from Azerbaijan and 40’000 Azeris from Armenia. ${ }^{87}$

The conflict was to take a temporary pause, due to the Spitak earthquake in Armenia on 7 December. ${ }^{88}$ Whereas this natural disaster and its immense human and material losses led to the temporary calming of the fervor, it posed a perfect opportunity for the Soviet government to take control of the events as the attention of the public was moved away from the conflict. Thus all eleven members of the Armenian 'Karabakh Committee' were arrested, on charges that they were

\footnotetext{
${ }^{78}$ See Kommunist, 16 June 1988.

79 See Los Angeles Times, 18 June 1988, p. A20.

80 See The Washington Post, 13 July 1988, p. A14.

81 See Altstadt, The Azerbaijani Turks, op. cit. [2], p. 198.

82 See Mark Saroyan, ”The 'Karabakh Syndrome' and Azerbaijani Politics”, in Problems of Communism, September/October 1990; Altstadt, The Azerbaijani Turks, op. cit. [2], p. 200-204.

${ }^{83}$ See Peter Rutland, “Democracy and Nationalism in Armenia”, in Europe-Asia Studies, vol. 46, no. 5, 1994, p. 844.

${ }^{84}$ See BakinskyRabochy, 22 and 23 November 1988.

${ }^{85}$ See The Washington Post, 25 November 1988, p. A1.

${ }^{86}$ See Izvestiya, 27 November 1998; Komsomolskaya Pravda, 27 and 29 November 1998.

87 See Bakinsky Rabochy, 3 December 1988; Kommunist, 25 November 1988, translation available in Current Digest of the Soviet Press, vol. XL no. 48, 1988, p. 15.

${ }^{88}$ See Current Digest of the Soviet Press, vol. XL nos. 50 and 51.
} 
obstructing the earthquake relief by refusing any aid coming from Azerbaijan. ${ }^{89}$ (which only led to the movement's increased popularity in Armenia, and to widespread disillusionment with Gorbachev, Perestroika, and the Soviet system as a whole ${ }^{90}$ ) and troops were sent in to Azerbaijan. Martial law was declared in Baku. ${ }^{91}$

On 12 January, 1989, the Soviet leadership decided to impose a 'special government administration' in Karabakh, without consultations with the Azerbaijani leadership. ${ }^{92}$ Thus the region was subjected to direct control from Moscow, although no changes were made regarding its legal belonging to Azerbaijan. Pogosyan, the NKAO head, was forced to retire, blamed for letting nationalism develop freely. ${ }^{93}$ Subsequently, Moscow's 'mediator' in the conflict, Arkadiy Volsky, was appointed head of the provisional government of the Oblast. Many Armenians saw this move as a transition period after which unification would be achieved, and hence a positive step. The NKAO was at least not practically under the jurisdiction of Azerbaijan. Azeris were for the same reason generally suspicious of Moscow's intentions, but saw a positive fact in the possibility for refugees from the NKAO to return. Up until this date, a report showed that 87 people had been killed by violence in the two republics and over 1500 wounded. ${ }^{94}$

This decision was instrumental in calming the situation for the following four months. But whereas there were no direct hostilities or riots during the period, there were no attempts to find a lasting solution to the Karabakh question either. Certain purges of the Armenian and Azerbaijani party structures were made against forces that had fanned or not seeked to prevent ethnic strife. However as a whole, the measures taken were meager. Many analysts agree that the move was less conditioned by a desire to resolve the underlying grievances than by a simply desire to preserve central power in the South Caucasus. ${ }^{95}$

Thus Moscow simply put a lid on the conflict without making a serious effort to deal with the long-run consequences. Consequently, it was inevitable that the conflict would flare up again. In the precarious conditions that are the case in ethnic conflicts, these months were actually a valuable period to initiate some conflict resolution mechanisms, such as organizing talks between the communities, providing a ground for confidence-building measures, or even dispatching peace-keepers (not just regular army units without a clear mandate, as was the case). This opportunity was lost in great part because of the incompetence of the men in Moscow, including Volsky himself who lacked the experience and background to deal with this type of problems. In a way this failure to act was also a result of the general decadence and lack of initiative in the

\footnotetext{
${ }^{89}$ See Krasnaya Zvezda, 14 December 1988, translation available in Current Digest of the Soviet Press, vol. XL no. 51, 1988, p. 7.

${ }^{90}$ See Goldenberg, Pride of Small Nations, op. cit. [6], p. 142.

91 See ”Azerbaijani Cracks Down on Extremists”, in Current Digest of the Soviet Press, vol. XL no. 52, 1988, pp. 8-10, compiled from Pravda, 26 December 1988, Bakinsky Rabochy, 26 December 1988; and Krasnaya Zvezda, 24 December 1988.

${ }^{92}$ See the collection of articles in Current Digest of the Soviet Press, vol. XLI no. 2, 8 February 1989, pp. 1-7, and in particular Pravda and Izvestiya, 15 January 1989, for the text of the decision. Also Michael Dobbs, ”Moscow Acts to Control Disputed Southern Area”, in The Washington Post, 13 January 1989, p. A23.

93 See The Washington Post, 21 January 1989, p. A20.

94 See David Remnick, "Ethnic Clashes Have Killed 87, Soviets Say”, in The Washington Post, 8 February 1989, p. A34.

95 See eg. Galina Starovoitova, National Self-Determination: Approaches and Case-Studies, Providence, RI: T.J. Watson Institute of International Studies, Brown University, 1997, p. 63.
} 
Soviet system. This said, the chances of any administration to stop the escalation of the conflict at this point were very doubtful. In any case the conflict was soon left to its own devices again.

By early May tensions had reemerged in the NKAO after the relative calm that had reigned since Moscow's take-over. Admittedly, this calm had been conditioned by the strict rules applied in the region, especially in Stepanakert. A curfew was in force, and military units patrolled boundaries between Azeri and Armenian localities. ${ }^{96}$ Street fights and clashes with ethnic character began to surface again both in Stepanakert and in Mardakert/Agdere to the North of the capital, and rallies emerged in Yerevan as well. ${ }^{97}$ Simultaneously the first 'spontaneous' fighting detachments of the conflict were formed by local Armenians in the Geranboy/Shaumian district north of the NKAO. $^{98}$ At this time, reports surfaced that acts of sabotage in Baku had been perpetrated by the Armenians Secret Army for the Liberation of Armenia (ASALA) based in Beirut. ${ }^{99}$

Meanwhile in Yerevan, the jailed members of the Karabakh committee were released in the end of May, and starting from June the committee started to merge with

Figure Error! Unknown switch argument.: Levon Ter-Petrosyan other smaller political forces and a new movement was

born: The Hayots Hamazgayin Sharjum, or Armenian National Movement (ANM). Levon Ter-Petrosyan emerged as the figurehead of the movement. In the first multi-party elections in May 1990, the ANM was able to become the single greatest group in the parliament, outnumbering even the Communist party. On 4 August, Ter-Petrosyan was elected chairman of the parliament. ${ }^{100}$

Simultaneously, in a parallel development in Azerbaijan, the Azeri Popular Front (APF) or Azärbaycan Xalq Cäphäsi was formed, and

Figure Error! Unknown switch argument.: Abülfez Elçibey officially founded in July of $1989 .{ }^{101}$ Just like in Armenia, the main momentum of the

\footnotetext{
${ }^{96}$ See Izvestiya, 10 May 1989, p. 2.

97 See Pravda, 14 May 1989; The Washington Post, 12 May 1989, p. A30.

${ }^{98}$ See Arif Yunusov, Statistics of the Karabakh War, Baku: Institute for Peace and Democracy, March 1996, p. 5.

99 Ibid.; Express-Khronika, no. 38, September 1993.

100 See Nora Dudwick, "Postcommunist Armenia: Images and Realities”, in Karen Dawisha and Bruce Parrott, (eds.), Conflict, Cleavage and Change in Central Asia and the Caucasus, Cambridge University Press, 1996, pp. 78-81.

${ }^{101}$ See Saroyan, op. cit. [82], pp. 22-25 for an excellent overview of the APF's emergence.
} 
movement's rise was the Karabakh issue, but unfortunately not in a more conciliatory way than in Armenia. In fact, among the population, an increasing anger and frustration was growing against the both the Karabakh Armenians, for their secessionism, but also against the republic's government, which was considered too soft on the issue, and seen as subservient to Moscow and ready to sell out Karabakh. ${ }^{102}$ Although the APF originally was formed as a movement for the promotion of democratization, pluralism and human rights, it drew its popularity from an increasingly rigid stand on the Karabakh question. ${ }^{103}$ The historian Abülfez Elçibey was elected chairman of the APF in its founding session. Thus a scene began to be set where the overwhelming majority of political forces in both republics had adopted a non-conciliatory approach to the conflict - this being valid both for the respective governments and their oppositions. In the end of June, a strike paralyzed Stepanakert and tensions escalated throughout July. ${ }^{104}$

In another development that month, Armenia started an embargo against Nakhjivan, and the newly formed APF answered by setting up an embargo against the whole of Armenia, which was badly hit by this development as over two thirds of Armenia's goods came through Azerbaijan. ${ }^{105}$ Thus Armenia's decision to try to isolate Nakhjivan seems to have been, to say the least, less than carefully examined.

Meanwhile the situation on the ground in Karabakh, was deteriorating. In August the Armenian members of the suspended Karabakh Soviet, led by representatives of the Dashnak party, set up a National Council, and reaffirmed their aim of unification with Armenia. From the second half of 1989 onwards, skirmishes and shoot-outs between armed bands became the rule rather than the exception, and the Soviet army's attempts to calm the situation by setting up checkpoints and searching cars and villages for arms were largely futile. Moreover, the army outposts were frequently attacked by paramilitaries and thus large amounts of weapons gradually came into the hands of the militias on both sides. This aspect was very important for the unpredictability of the conflict: Arms were in overflow in the region, as in the entire Caucasus. This fact contributed to making the conflict uncontainable as the monopolization of the use of force was no longer possible.

Then, on 28 November, the Soviet direct command was abolished, as if Moscow accepted its failure and left Nagorno Karabakh to its destiny. ${ }^{106}$ Thus the Oblast was returned to Azeri control, and a military rule was initiated. Answering to this development, the Armenian Supreme Soviet on 1 December, 1989, took the historical decision to promulgate the incorporation of Nagorno Karabakh into the Armenian republic. The declaration stated as follows:

1. The Armenian Republic Supreme Soviet recognizes the fact of the self-determination of the Nagorno-Karabakh Autonomous Province, a fact established by the Feb. 20, 1988 and July 12, 1988 decisions of sessions of the Nagorno-Karabakh Province Soviet, as well as by the Aug. 16, 1989

\footnotetext{
102 See Audrey L. Altstadt, ”Azerbaijan’s Struggle Towards Democracy”, in Dawisha and Parrott, op. cit. [100], pp. 120-122.

103 See Elizabeth Fuller, “The Ongoing Political Power Struggle in Azerbaijan”, in Radio Free Europe/Radio Liberty Research Report, v. 1, no. 18, 1 May 1992.

104 See Pravda and Izvestiya, 5 and 8 July 1989; Izvestiya, 14 July 1989, p. 6.

105 See Pravda, September 22, 1989, and Saroyan, op. cit. [82], p. 25.

${ }^{106}$ See Interview with Volsky in Current Digest of the Soviet Press, vol. 41, no. 49, 1989, pp. 19-20.
} 
decision of the Congress of Authorized Representatives of the province's population and the Oct. 19, 1989 decision of a meeting of the National Council. (...)

3. The Armenian Republic Supreme Soviet and the Nagorno-Karabakh Republic Council proclaim the reunification of the Armenian Republic and Nagorno-Karabakh. The rights of Armenian Republic citizenship extend to the population of Nagorno-Karabakh (...)

6. The Presidium of the Armenian Republic Supreme Soviet, the Armenian Republic Council of Ministers and the Presidium of the Nagorno-Karabakh National Council are instructed to take all necessary measures arising out of this resolution to effect a real merging of the political, economic and cultural structures of the Armenian Republic and Nagorno-Karabakh into a unified state-political system. $^{107}$

As a result a union of the two entities was a legal fact, and translated into practice as a joint budget for the two entities was decided in the beginning of January.

In January 1990, the main scene of action moved to Azerbaijan. On the $11^{\text {th }}$, Armenian villages in the Khanlar and Geranboy/Shaumian districts were cleansed of Armenians. ${ }^{108}$ For the first time, heavy weaponry such as helicopters and armed personnel carriers were used here; Baku, however, was to be the scene of the world's attention the next weeks. On the $11^{\text {th }}$, the APF organized a rally in protest of the government's inactivity, and on the 13th and 14th, Azeri refugees from Armenia started a pogrom on Armenians, leading to the death of at least 88 people. ${ }^{109}$ The Soviet militia, present en masse as it was in Baku, repeated its actions in Sumgait and did what it would do in most cases of ethnic strife-nothing. The APF condemned the riots, denounced the republican leadership and Moscow for not intervening and argued it did so to justify an invasion of Baku, as it was afraid of the APF coming to power in Azerbaijan. ${ }^{110}$ These allegations were proven true less than a week later, as over 29'000 Soviet troops rolled into Baku on January $20 .{ }^{111}$ In the chaos that followed the intervention and in the brutal suppression of the resistance in the city, casualties rose first to 83, then to over a hundred according to official sources, and to over 500 and even thousands according to the APF. ${ }^{112}$ Meanwhile a state of emergency was proclaimed in Karabakh, and thousands of troops dispatched there as well. On 26 January, soviet defence minister Dimitri Yazov conceded in a press conference that 'the military occupation of Azerbaijan's capital was designed to prevent the Azerbaijan Popular Front from seizing power from the Communist Party'.113

In this chaotic condition, the leaders of the popular fronts of the Baltic republics succeeded in arranging a meeting between their Azerbaijani and Armenian counterparts, that is the APF and the

\footnotetext{
107 See Kommunist, 3 December 1989, p. 1.

108 Mouradian, ”The Mountainous Karabakh Question”, op. cit. [32], p. 28; Mutafian, ”Karabagh in the Twentieth Century”, op. cit. [12], p. 156.

109 The Christian Science Monitor, 19 January 1990; Izvestiya, 16 January 1990 gives a figure of 56 dead. Over 200 wounded were also reported; Arif Yusunov cites a figure of at least 88. Yunusov, Statistics of the Karabakh War, p. 6.

110 Izvestiya and Pravda, 19 January 1990. Translations in Current Digest of the Soviet Press, vol. 42 no. 3 , 1990.

111 See Michael Dobbs, "Soviets Send Troops to Quell Nationalist Fighting in South”, in The Washington Post, 16 January 1990, p. 1; The Washington Post, 17 January 1990, p. 1; David Remnick, ”Soviet Troops Attack Militants: Azerbaijanis Say Death Toll High", in The Washington Post, 20 January 1990, p. 1.

112 See Dan Oberdorfer, ”Azerbaijani Capital Demands Withdrawal of Soviet Troops: Scores Killed in Army Crackdown in Baku”, The Washington Post, 22 January 1990, p. 1.

113 See Michael Dobbs, ”Soviets Say Troops Used to Avert Coup in Baku: Nationalists Said to Plan Seizure of Power", in The Washington Post, 27 January 1990, p. A13.
} 
ANM, in Riga on 3 February. ${ }^{114}$ Although neither of the movements were in possession of political power at the moment, they would be the main actors in the domestic sphere of their respective republics before long. Thus the meeting taking place was by itself a success; however its outcome was less successful. In fact it set a precedent, in a way, for the attitude of the parties towards the conflict: The Armenians invoked the principle of peoples' right to self-determination, and the Azeris defended the principle of territorial integrity. ${ }^{115}$ The meeting ended there, with both parties only announcing their own point of view without leaving any room for compromise.

By April, Armenia's protests against the military rule in Karabakh became more vocal, and the Armenian leadership blamed the Soviet military of enflaming the conflict, as they allegedly cooperated with Azeri OMON (Interior Ministry special forces) forces in setting up 'checkpoints' in Karabakh controlling passports and residence permits, and searching for arms. Hence shortly before the late May celebrations of Armenia's declaration of independence in 1918, Armenian militants seeked to get hold of weapons from army depots in Yerevan, leading to 22 dead. ${ }^{116}$ These events occurred shortly after Armenian officials decided to include Nagorno-Karabakh in the upcoming Armenian elections. ${ }^{117}$ In this case, the Armenian leadership went against the soviet central government, rejecting a decree from Moscow ordering armed nationalist groups to surrender arms. ${ }^{118}$

Simultaneously paramilitary formations grew in number and strength on both sides, as the parties seemed to turn to build up for a military solution of the conflict. Again the Armenians were more active than the Azeris, who seemed to rely more upon the Soviet central government for a solution despite the Baku events of January, and a considerable, and according to HRW ‘increasingly open' flow of arms from mainland Armenia to Karabakh was reported. ${ }^{119}$ Observers have noted how planes loaded with military equipment, coming from Beirut, landed in Yerevan and how the materiel was subsequently transported to Karabakh. ${ }^{120}$ In this environment of heavily armed paramilitary forces, the escalation of the armed conflict became irreversible.

In August, Armenian paramilitary forces attacked eight Azerbaijani villages in the Kazakh district in Northwestern Azerbaijan; Soviet military supported the Azerbaijani self-defence forces, leading to deaths of over a dozen people on each side. Meanwhile, in the Khanlar district, Azerbaijani OMON forces attempted to assert control over Armenian-populated villages, leading to clashed that left over a dozen dead. ${ }^{121}$

\footnotetext{
114 See Michael Dobbs, "Warring Soviet Groups Set Agenda for Talks: Armenians, Azerbaijanis to Meet in Latvia” in The Washington Post, 30 January 1990, p. A15; also The Christian Science Monitor, 7 February 1990.

${ }^{115}$ Yérasimos, “Caucase: Le Retour de la Russie”, op. cit. [58], p. 69.

116 See Michael Dobbs, ”Armenia in Mourning after Clashes Kill 22: Soviets Blame Nationalists' Quest for Arms”, in The Washington Post, 29 May 1990, p. A18; International Herald Tribune, 29 May 1990.

117 The Times, 28 May 1990.

${ }^{118}$ See Brian Freedman, "Armenia Rejects Soviet Order for Militants to Turn in Arms”, in The Washington Post, 31 July 1990, p. A17.

${ }^{119}$ Human Rights Watch/ Helsinki, Azerbaijan: Seven Years of Conflict in Nagorno-Karabakh, New York : Human rights Watch, 1994, p. 3.

120 See Yérasimos, “Caucase: Le Retour de la Russie”, op. cit. [58], p. 69, citing an article by Claude-Marie Vadrot in Le Journal du Dimanche, 21 January 1990.

${ }^{121}$ Yunusov, Statistics of the Karabakh War, p. 7.
} 
Sporadic clashes became frequent by the first months of 1991, with an ever-increasing organization of paramilitary forces on the Armenian side, whereas Azerbaijan still relied on the support of Moscow. Interestingly, the main area of these sporadic clashes was not the NKAO itself but the Khanlar and Geranboy/Shaumian raions between the NKAO' northern border and Ganje. According to Azerbaijani interior ministry sources, there had been a notable increase of illegal Armenian migration to these districts in order to artificially alter the composition of the local population.

In response to this development, a joint Soviet and Azerbaijani military and police operation directed from Moscow was initiated in these areas during the Spring and Summer of 1991. The purpose of the operation was ostensibly to carry out identity controls, but in reality led to the clearing of up to 24 Armenian-populated villages on the northern periphery of the NKAO: reports talked of 'search-and-destroy' operations, with the aim of eradicating paramilitary forces. ${ }^{122}$. Interior ministry sources claimed to have confiscated substantial numbers of small arms from both Armenians and Azeris. The operation, entitled Operation Ring, was evidently carried out in a very harsh way, with systematic violations of Human Rights. ${ }^{123}$ After the conclusion of the operation, the Armenians that had been evicted took to arms to return to their villages leading to increasing clashes, and the number of casualties began to rise sharply. By June 1991, the casualties of the conflict were estimated at 816.

On 2 September 1991, the resuscitated Karabakh Soviet, renamed the 'Karabakh National Council', proclaimed the independent republic of Nagorno Karabakh over the territory of the Nagorno-Karabakh Autonomous Oblast and the Geranboy/Shaumian district of the Azerbaijani republic. This move took place following the declarations of independence of most Soviet union republics after the failed August coup against Gorbachev. Obviously, Nagorno-Karabakh, like Chechnia to the North, thought it could jump on the wagon of independence in this totally new atmosphere that was created by the specter of the Soviet Union's de facto dissolution. ${ }^{124}$

During Autumn, Azerbaijani forces moved to counter Nagorno Karabakh's declaration of independence, and Armenians respond by establishing armed control over key villages. This led to a flare-up of armed conflict in a situation when the Soviet army was in a state of confusion regarding its future. ${ }^{125}$ However, a temporary pause was due to the mediation attempts by Boris Yeltsin and Nursultan Nazarbayev on 20-23 September, which produced an agreement to further talks between the republican leaderships, ${ }^{126}$ and a cease-fire a few days later. ${ }^{127}$ However, this did not mean a stop to fighting, as the republican governments had very much lost control over the armed units which had been proliferating for over two years in both republics. Before the ink on the agreement's paper had dried, in the words of Thomas Goltz, Azeri villages in Karabakh had been the target of renewed violence. ${ }^{128}$ As the Azerbaijani government realized the military force

\footnotetext{
122 The Economist, 16 May 1991.

${ }^{123}$ Human Rights Watch/ Helsinki, Azerbaijan: Seven Years of Conflict in Nagorno-Karabakh, p. 4.

${ }^{124}$ See discussion in Vaserman and Ginat, ”National, Territorial or Religious Conflict?”, op. cit. [35], p. 355.

125 See The Washington Post, 15 September 1991, p. 1.

${ }^{126}$ See Fred Hiatt, ”Armenians, Azerbaijanis Agree to Talks on Disputed Enclave; Opposition Forces Clash With Government Troops in Soviet Georgia” in The Washington Post, 23 September 1991, p. A13.

127 See Fred Hiatt, ”Armenia, Azerbaijan Agree to Cease-Fire: Yeltsin, Kazakhstan President Broker Initial Accord over Disputed Nagorno-Karabakh”, in The Washington Post, 25 September 1991, p. A20.

${ }^{128}$ See Thomas Goltz, ”On The Back Roads to a Civil War: Despite the Recent Agreement, the Azeri-Armenian Conflict Goes On”, in The Washington Post, 6 October 1991, p. C2.
} 
behind the Karabakh Armenians, it proceeded to nationalize all military hardware in the republic and to recall all Azeri conscripts from the Soviet army. Furthermore, as a direct answer to the declaration of independence, the Azeri parliament on 26 November abolished the autonomous status of Nagorno Karabakh, dividing its territory among the surrounding districts. Naturally, this move has more of a theoretical political importance than a real value, since the military control of the region was rapidly slipping out of Baku's hands. On 8 December, a referendum was organized in Karabakh to confirm the secession, and not surprisingly, 99\% of the cast votes are in favour, especially since the Azeri population boycotted the referendum. Simultaneously the Soviet troops were withdrawn from the region, which left the parties in direct confrontation, without any buffer between them.

As the Soviet Union ceased to exist, all leverage or even calming effect that Moscow might have had on the belligerents was removed. Especially for the Azeris, this was an unexpected and unwanted development. Whereas the Armenians had prepared themselves to solve the problems by themselves and with arms, the Azeris had been expecting Moscow to solve the conflict on their terms. Thus the rapid dissolution of the Soviet Union was a catastrophe for Azerbaijan, whose military preparation was incomparable to that of the Armenians. With an unorganized and badly motivated army, the Armenians seemed poised to resolve the issue in their favour. However, the issue can be raised whether the declaration of independence of Karabakh implied a division between Stepanakert and Yerevan. The declaration apparently points at a divergence of policy — whereas at an earlier stage the concurrent aim of Armenia and the Karabakh Armenians had bee union of the two entities, that is reunification under Yerevan's authority, the Karabakh Armenians seem to have changed their mind and now advocated an independent state.

However the picture of a division between Stepanakert and Yerevan doe not fully comply with reality. To a certain extent it may be a diplomatic trick to reduce Yerevan's responsibility and accountability for the actions of the Karabakh Armenians: in peace negotiations during 1993-96, Armenia has constantly argued that it is not strictly speaking a party to the conflict although it supports the right to self-determination of their ethnic kin in Karabakh. consequently, the Armenian government is not responsible for the actions of the Karabakh Armenians and cannot speak for them, nor impose any policy on them, except by friendly advice. The exchange of government officials between the two capitals throughout the war-culminating in Karabakh's President becoming Armenia's President in 1998-seems to lend credence to this point. Moreover, Karabakh can be said to control Armenia to a much higher extent than the opposite; this circumstance is noted by several Armenian observers. ${ }^{129}$

\section{The Mirroring Nationalisms}

There is one point that strikes the observer of the Armenian-Azeri conflict. That is the lack of interaction and dialogue between the leaderships of the two republics even at a very early stage of the dispute. Indeed, there seems to have been no-one in a power position, in any of the republics, at any time, that was interested in a dialogue and a peaceful resolution of the conflict through compromise. This is particularly interesting for two reasons: The first is that this has been an effective solution to other comparable conflicts; the second is that the two republics were for all

\footnotetext{
${ }^{129}$ Personal communication to author from several sources; eg. Manvel Sargsian, senior analyst at the Armenian Center of National and International Studies and former representativ of Nagorno-Karabakh to Armenia, January 1999.
} 
practical purposes part of the same country, a factor which should have worked against the escalation of the conflict. As Ted R. Gurr has noted,

Negotiated regional autonomy has proved to be an effective antidote for ethnonational wars of succession in Western and Third World states ... In several of these instances, ... settlements were rejected by factions that continued to fight, but the intensity of the conflict nonetheless declined markedly. ${ }^{130}$

This clearly does not apply to the case of Nagorno Karabakh. The reason for this is simple: There was no readiness nor a will for compromise on either side. The events and the escalation of tensions, rather than bringing an insight that a peaceful solution must be found to avoid bloodshed, only served to antagonize the parties and lock them into their respective extreme positions. This is all the more remarkable as the Armenians and Azerbaijanis had a great advantage over parties to other conflicts: The institutions for commencing a dialogue and a discussion, and eventually negotiating a compromise, were present at all levels in the form of the Soviet Union. Leaders of the two republics met frequently at union-level meetings, which under all circumstances provided a framework for a dialogue; also most Azeris and Armenians could communicate through the Russian language. Nevertheless, the leaders of the communist times were unable to take advantage of the existing opportunities to reach a peaceful settlement to the conflict, something that seems to have been possible well into 1990, at the very least.

The inability of the communist leaders to provide constructive thinking might be explained by their belonging to a petrified and stagnant institution, which coloured their mind and enhanced their narrow-mindedness. This would be a plausible explanation if the statement was valid only for the Communists in the two republics. Unfortunately, this was not the case.

For as the opposition movements grew starting from the late 1980s, they invariably and with few exceptions took a nationalist overtone. The first non-communist leaders of both Armenia and Azerbaijan, Levon Ter-Petrosyan and Abülfez Elçibey were products of the popular fronts of their respective republics, which both had nationalist orientations and were in fact strongly related to the Karabakh dispute. This was the case especially in Armenia, where the ANM actually grew out of the Karabakh committee: in Armenia, a government was formed whose political origin was nothing else than an organization founded for the very purpose of advancing the conflict in Karabakh.

Thus it is truly amazing how the opposition movements grew strong without even once approaching to one another, trying to surpass their governments by mutually attempting to solve the conflict. Contrary to the developments in many other parts of the Soviet Union and particularly in the Baltic states, the Azeri Popular Front and the Armenian National Movement were as much responses to one another as parallel developments. The period from 1985 to the present has often been labeled as a period of nationalist revival in Eastern Europe and the Soviet Union. In Azerbaijan and Armenia, this argument can be drawn one step further: It indeed seems appropriate to say that the Azeri and Armenian nationalism are actually mirrors of each otherthey emerged as responses to one another and owe their whole existence to one another. As Yérasimos notes,

\footnotetext{
130 Ted Robert Gurr, “Peoples Against States: Ethnopolitical Conflict and the Changing World System”, in International Studies Quarterly, September 1994, p. 366.
} 
If the Georgian nationalism positions itself in the middle, between that of Russia and those of the smaller peoples within Georgia, thus creating a hierarchy, (which does not prevent-quite the opposite- the alliance of extremes), the Armenian and Azeri Nationalisms send back each other's images like a deforming mirror, as if they can exist only by opposition to one another. ${ }^{131}$

The analogy of the deforming mirrors is indeed well found. For the popularity, and thus the existence, of the two movements was deeply related to the achievement of a victory in the Karabakh dispute. This is only proven by the fact that Ter-Petrosyan until recently had been sitting quite calmly in his chair, despite the economic crisis, embargoes and isolation of his country whereas Elçibey was ousted from power due to the debacle in Karabakh that he presided over.

Mark Saroyan, in an interesting article coined the term 'Karabakh Syndrome'. Although in his article from 1990 he exclusively uses the term for Azerbaijani politics, it seems that this term would also be useful to explain the general situation both in Azerbaijan and Armenia. By the word syndrome, we refer to something with medical connotations, something pathological. And indeed, the form in which the mirroring nationalisms developed, one could say, is nothing less than pathological, as are the atrocities committed during all stages of the conflict. Indeed, in the case of this conflict, one can claim that pogroms and localized ethnic unrest led to the escalation of political conflict—which gives the conflict a mass-led character, as compared to the elite-led conflicts in Moldova and former Yugoslavia, as Stuart Kaufman has found in his research on the post-Communist conflicts. ${ }^{132}$ In the case of Azerbaijan, the pogroms of Sumgait and Baku especially, whether initiated by the Russian authorities or not, are pathological enough but become intelligible-although never justified—by the role of the Azeri refugees from Armenia, who themselves had recently suffered harassment, humiliation and atrocities. The fact that these refugees were the ones to initiate the pogroms follows the logic of ethnic conflicts. In the case of militants among the Armenians in Karabakh as well as in Armenia, however, the pathological strait is all the more present since the atrocities were carried out on a more systematic, although less explosive basis. In Azerbaijan, the pogroms were incidents of anger and frustration, which does not excuse them but shows them to be incidental occurrences rather than systematic policy. The Karabakh Armenians, on the other hand, seem to have taken the example of the notorious Bosnian Serbs in their systematic ethnic cleansing of the Azeris in Karabakh and later its surrounding regions, using all known practices ranging from mass murder to all forms of intimidation designed to create fear. This was especially clear during the first months of February 1992 when the small Azeri town of Khojaly was overrun by Karabakh forces, supported by the

\footnotetext{
${ }^{131}$ Yérasimos, “Caucase: Le Retour de la Russie”, op. cit. [58], p. 65. (Translation from French is my own).

132 See Stuart J. Kaufman, "An 'International' Theory of Inter-Ethnic War”, in Review of International Studies, vol. 22 no. 2, 1996. For the case of Karabakh, see Kaufman, Ethnic Fears and Ethnic War in Karabakh, op. cit. [50]; also "Spiraling to Ethnic War: Elites, Masses, and Moscow in Moldova's Civil War" in International Security, vol. 21 no. 2, 1996; "An 'International' Theory of Inter-Ethnic War", in Review of International Studies, vol. 22 no. 2, 1996.
} 
366th CIS infantry regiment. The town was all but destroyed, thousands of people were killed and the rest of the population was forced to flee over the mountains to seek refuge. This event was the first instance of atrocities committed against Azeris to reach the headlines of the world media, whereas anti-Armenian events in Baku and other areas in Azerbaijan had done so in numerous instances. The 'syndrome' of mirroring nationalism was not to be stopped. And this was because no one was there, no one was strong enough to make sense prevail. 


\section{3}

\section{War: 1992-94}

By early 1992, the power vacuum created by the dissolution of the Soviet Union led to the loss of the last factor containing the conflict. Thus with the imminent withdrawal of the formerly Soviet forces, Karabakh became the scene of what gradually increased to a full-scale war. The Armenian side, having prepared itself to solve the conflict through military means, did not loose any time to act. From early February onwards, the Azeri villages of Malybeili, Karadagly, and Agdaban were conquered an their population evicted, leading to at least 99 civilian deaths and 140 wounded. ${ }^{133}$ After two days of artillery fire Armenian forces on 27 February, according to many impartial observers supported by the 366th CIS (formerly Soviet) motor rifle regiment, seized the small but strategically placed town of Khojaly, on the Agdam-Stepanakert road. ${ }^{134}$ This conquest was the first step in a series of atrocities to follow during the subsequent Armenian conquest of Karabakh and its surrounding areas.

\section{The Shock of Khojaly}

The attack was ostensibly carried out as a response to artillery fire from the town on the Karabakh Armenian capital of Stepanakert, only seven kilometers away. However the events that followed showed another side of the conquest. Khojaly was the victim of ethnic cleansing of the worst kind. A great part of the civilian population of the town, numbering 7000 before the attack, was mutilated and killed, and the remaining population was forced to flee over the mountains to seek refuge. As is the case in most instances of ethnic cleansing, the atrocities carried out by the aggressor served a double purpose: To force the population to flee and never to come back, but also to intimidate other inhabitants of nearby villages to leave their homes, fearing similar actions. The death toll of Khojaly is debated; Armenians, naturally, tend to understate the number and estimate the deceased civilians to be less than a hundred; furthermore Armenian sources, in the rare cases they mention the event, blame the Azeris for using Khojaly as a base for rocket attacks on Stepanakert. Moreover they blame Azeris for using the Khojaly residents as human shields, and claim that the civilians were caught in cross-fire rather than massacred. ${ }^{135}$ Other authors, including experts on the region close to the Armenian position, embark on an emotion-laden defence of the Armenian side's ethnic cleansing policies, seeming to have difficulties comprehending that both sides to a conflict commit atrocities and that no one side is without

\footnotetext{
${ }^{133}$ Yunusov, Statistics of the Karabakh War, op. cit.[98], p. 9.

${ }^{134}$ The best account of the events of this time can be found in chapter seven, "Khojaly", in Thomas Goltz, Azerbaijan Diary: A Rogue Reporter's Adventures in an Oil-rich, War-torn Post-Soviet Republic, New York: ME Sharpe, 1998.

${ }^{135}$ See Levon Chorbajian, "Introduction to the English-Language Edition”, in Chorbajian et. al., The Caucasian Knot, op. cit. [12], p. 29.
} 
blame. A quotation from Christopher Walker, a well-known expert and author of several books on Armenia, is elucidating:

\begin{abstract}
In a controversial action, the Armenians took control of Khojalu in February 1992. Allegations of a massacre of the civilian population of the town were made, but several events surrounding its capture were not widely reported: First, the Armenians warned the people of Khojalu that they were planning to take the town, and told them to quit ... Secondly, a week after the capture of the town the Armenias invited the Azerbaijanis to claim their dead. Neither of these open actions is characteristic of a group seeking to carry out a massacre. ${ }^{136}$
\end{abstract}

Walker seems to defend the opinion that warning a population of a forthcoming invasion voids any blame for future atrocities. In a way, this amounts to implying that as the inhabitants of the town did not 'quit' - in itself a rather peculiar way of describing a refugee forced to leave his home - they only had themselves to blame if they were brutalized. This in turn is nothing but a justification of ethnic cleansing and the military conquest of land. Regarding the second argument made by Walker, it should be noted that Khojaly only numbered roughly seven thousand people. A week's time is largely sufficient to erase traces of a massacre. In addition, Muslim burying customs dictate that the dead must be buried hastily, preferably within 24 hours; as a result any bodies which Azeris could have had access to after the massacre would have been buried within a week of the massacre.

Despite the claims of Armenians and their proxies, it is beyond doubt that a massacre of civilians took place. Whereas Azeri sources put the death toll at over a thousand, the official Azerbaijani investigation put the figure at 'over 600'. ${ }^{137}$ Western journalists present in Karabakh and Agdam at the time, including Anatol Lieven and Thomas Goltz, published their accounts of the events, where evidence of a massacre is overwhelming. ${ }^{138}$ Human Rights organizations have estimated the figure at anywhere between 200 and $1000 .{ }^{139}$ It should be recalled however, that just like in the Sumgait and Baku riots, the numbers are important only to illustrate the extent, but not the nature, of the events.

Interestingly, however, the participation of whole units part of the $366^{\text {th }}$ CIS infantry regiment was noted in the occupation of Khojaly and subsequent attacks on Azeri settlements. ${ }^{140}$ The $366^{\text {th }}$ regiment, which was the last armed force preventing an all-out war between the parties, was withdrawn in March, that is before the final Armenian push on Shusha, the Azeri stronghold in Karabakh.

\footnotetext{
136 Christopher Walker, ”The Armenian Presence in Mountainous Karabakh”, in John F. Wright, Suzanne Goldenberg and richard Schofield, (eds.), Transcaucasian Boundaries, London: UCL Press, 1996, p. 109.

137 See Hugh Pope, "600 Azerbaijanis slain at Khojaly, investigator says”, in The Los Angeles Times, 12 June 1992, p. A6.

138 Thomas Goltz, ”Armenian Soldiers Massacre Hundreds of Fleeing Families”, The Sunday Times, 1 March 1992; Anatol Lieven, "Corpses Litter Hills in Karabakh”, The Times, 2 March 1992; "The Face of a Massacre”, Newsweek, 16 March 1992; "Massacre by Armenians”, The New York Times, 3 March 1992; The Age, (Melbourne), 6 March 1992.

${ }^{139}$ Human Rights Watch/Helsinki estimates the number to range between 200-1000. See Human Rights Watch/ Helsinki, Azerbaijan: Seven Years of Conflict in Nagorno-Karabakh.

${ }^{140}$ Paul Quinn-Judge, ”In Armenian Unit, Russian is Spoken”, The Boston Globe, 16 March 1992.
} 


\section{The Armenian Upper Hand}

In the months following the Khojaly massacre, the Karabakh Armenians continued their offensive, supported by 'volunteers' (in reality, especially in later stages of the conflict, regular units of the Armenian army) from Armenia. The Report of Human Rights Watch/Helsinki clearly shows the involvement of whole Armenian army units in Karabakh, on a non-voluntary basis. Statements of Armenian prisoners of war confirm this fact. ${ }^{141}$ Although there have been a great number of volunteers, both from Armenia and the Diaspora as a whole, the issue of Armenian troop involvement is important in legal terms, as is discussed below. In May, the towns of Shusha and Lachin were conquered, creating a corridor between Armenia and Karabakh. Until then, the two entities had been separated by Azeri military presence in the thin corridor separating Karabakh from Armenia, a situation that made it difficult for Armenian supplies to reach Karabakh. Thus from a logistical point of view, this linkage was crucial for the future development of the war. Also from a military and political viewpoint, this event was of utmost importance. For every practical purpose, Karabakh could now be integrated into Armenia, although for political reasons this integration is still denied. A common budget was already in place for the two entities, and presently over $85 \%$ of the budget of Karabakh is provided by the government of Armenia, which spends 5-10\% of its national income on Karabakh. The refusal of Armenian representatives to even discuss renouncing the Lachin area in international negotiations shows to the critical importance of the issue for the Armenian side.

This development led to an Azeri counter-offensive in June 1992, which succeeded in recapturing Agdere/Mardakert, and the Shaumian region in the North of Karabakh. This Azeri counter-offensive proved to be short-lived. The Armenians, after having regrouped their forces and gathered strength, mounted a large-scale offensive in February 1993 which recaptured many parts of the Agdere/Mardakert region lost in June 1992; the eastern flank of the Kelbajar region of the Azerbaijani republic (outside Nagorno Karabakh) was captured as well. Meanwhile, South and East of Karabakh, that is in the Fizuli and Agdam regions respectively, fighting started to erupt in the form of artillery duels and sporadic raids.

The fall of Agdere/Mardakert was an event which seems to have been related with internal Azerbaijani politics. The June offensive which brought the region back under Azerbaijani control had been the work of several more or less private armies. These included that of Surat Husseinov, the manager of a textile factory, who agreed to invest his fortune on supporting the newly-formed Azerbaijani military forces; of Iskender Hamidov, the leader of the Bozkurt or pan-Turkic nationalists; and of Yaqub Mamedov, the leader of the Mudafah Shahinlar, or Defense Falcons. ${ }^{142}$ Husseinov however was given much credit for the advances, was appointed Colonel and led the army formations, which were under his personal control rather than under the control of the Azerbaijani military leadership. Whereas these various forces, well-organized by Azerbaijani standards, were able to conquer back Agdere/Mardakert, Husseinov blatantly failed to defend Kelbajar against the Armenian counter-offensive.

In fact the Elçibey government in early February dismissed defense minister Rahim Gaziev as well as Husseinov. ${ }^{143}$ As Husseinov was stripped of his position of 'generalissimo' in Karabakh,

\footnotetext{
${ }^{141}$ Human Rights Watch/ Helsinki, Seven Years of Conflict, p. 70 among other.

142 See Goltz, Azerbaijan Diary, pp. 150-153 on Mamedov.

${ }^{143}$ Ibid., pp. 325-326.
} 
due to the shady connections he and Gaziev shared with Moscow, Husseinov simply decided to leave the front and retreat his troops to Ganja, which remained his personal stronghold from where he was to base his 'march on Baku' only a few months later. This led to the government to accusing Husseinov of betraying the nation, but in practice only meant that Husseinov's men, previously at least nominally under state control, were reverted into a virtual private army. The sacking of Husseinov, admittedly, was part of a general reorganization of the army; nevertheless, the amount of power vested in the person of Husseinov, especially in his hometown Ganja, together with his unpredictability, was perceived (quite rightly, as would become clear within a few months) as a threat to the stability of the regime.

After the defection of this army unit, the chaotic condition of the Azerbaijani armed forces only worsened. The troops' morale was at an all-time low, desertions were commonplace, politics were intermingled with the military, and the events on the battlefield went from bad to worse. In March and April 1993, the Karabakh Armenians took up a major offensive, this time supported by the Armenian Republic's armed forces. Kelbajar, populated by a majority of Azeris and a minority of Kurds, and its surroundings fell in the first days of April and over 60'000 civilians were forced to flee northward over the Murov pass. Little later, Fizuli, another homogeneously Azeri area to the Southeast of Karabakh was captured, and again the area was cleansed from all Azeris in a matter of days.

After these impressive military victories on the Karabakh Armenian side, the Armenians announced a cease-fire on 16 April. Meanwhile, international attention grew and Boris Yeltsin attempted to mount tripartite talks to put an end to the fighting. By this time the conflict had surpassed any predictions; the number of Azeris forcibly displaced since the beginning of the conflict was approaching a million, and it seemed increasingly clear that the Karabakh Armenians were not happy with controlling Nagorno Karabakh, nor even with a corridor to Armenia. What they wanted was to stitch Nagorno Karabakh together with Armenia from North to South ${ }^{144}$ to make a fait accompli of its integration with Armenia. Morevoer they managed isolate it from Azerbaijan by a cordon sanitaire of previously Azeri areas which after having been emptied of civilian population would enable the Armenians to have a buffer zone towards Azerbaijan. It does not seem as if they wanted to populate the area - with the notable exception of Lachin and to a lesser extent, Kelbajar, or actually integrate the areas South and East of Nagorno-Karabakh into their future political boundaries. This conquest rather followed military predicaments but was also carried out in order to obtain a bargaining chip in future negotiations, especially since the ease with which it was done posed no particular cost to the Karabakh leadership.

Nevertheless an international reaction, although embryonic, was emerging. It seems as if most actors on the international scene, including the Russians, thought the Armenians had gone too far. In this atmosphere, the UN Security Council passed resolution 822, which called for the withdrawal of the (unidentified) forces occupying Kelbajar. Russia, the United States, and Turkey jointly proposed a peace plan, which was accepted by both the governments of Armenia and Azerbaijan. However, the Karabakh Armenians refused to accept any peace plan. This may be construed as an indication that the Armenian government's control over its Karabakh allies was fading; however it seems equally likely that the Armenian government used the argument of not being able to control the Karabakh officials as an excuse, a pretext for pursuing its own goals and

\footnotetext{
${ }^{144}$ In the expression of Thomas Goltz. Personal correspondence.
} 
avoiding a diplomatic embarrassment. Indeed many analysts see the supposed ArmenianKarabakh split as a fig leaf for Armenia to keep up its semblance of non-involvement. Several outspoken Armenian observers contend that far from exerting any control over Karabakh, the Armenian government has in fact from the start been controlled from Karabakh. This rationale is strengthened by the sudden appointments of Karabakh officials to the Armenian government- the most blatant proof being the appointment of Karabakh President Robert Kocharyan as Prime Minister of Armenia in 1997 and his subsequent elevation to the presidency though a 'palace coup' (see below). In any case, no agreement ever materialized from the tripartite plan, and soon events in Azerbaijan were to make the scene even more confused.

\section{Azerbaijan's Disastrous Internal Distractions}

In June, Surat Husseinov emerged again from his stronghold in Ganja, profiting from the popular discontent of the Elçibey government's handling of the war. The tension in Ganja had been growing ever since Husseinov repeatedly refused to return to the front in Karabakh and assume his duties as a field commander, when ordered to do so by the defence ministry. In May, the $104^{\text {th }}$ airborne Russian regiment stationed in Ganja - in fact neighbouring Husseinov's barracks - suddenly decided to retreat from Azerbaijan, over six months ahead of schedule. This was an unprecedented act of the Russian army, otherwise so eager to hang on to bases the South Caucasus. Only, the $104^{\text {th }}$ regiment left almost all its weapons in Husseinov's hands; this, together with the known close links between Husseinov and Moscow, was naturally very worrying for the Elçibey regime. Russia wanted to take control over Azerbaijan but did not want to make as if it was in the eyes of the world; if Husseinov took power and asked the Russians to come back, everything would look neat. The Russian hand behind Husseinov is discussed in detail in chapter 4. In the beginning of June, the tensions between the nervous government and Husseinov culminated when defence ministry troops were ordered into Ganja to restore order and assert control over the arsenal given to Husseinov by Russia. As the government forces moved on Ganja, Husseinov took civilian hostages as shields, whereby the government retreated, in an effort to avoid bloodshed. It was at this point, according to government sources, that some twenty government troops were ambushed and killed. ${ }^{145}$ Husseinov also captured several high-ranking government officials which he held responsible for the fighting.

The next day, Husseinov told his men to march on Baku to 'clean out the filth' he proceeded to secure control of Ganja as well as Yevlah, to the East of Ganja, and a first detachment of troops started marching on Baku. According to reports, the size of this detachment may have been as small as 50 and in any case less than a hundred men. The government forces refused to fight, or were ordered not to. Husseinov's forces marched until they were fifty kilometers from Baku; claiming they would not stop until Elçibey stepped down. Breaking several days of silence, Elçibey sent three helicopters to strike out Husseinov's first venture. None of them came back; all switched sides and joined the rebellion. ${ }^{146}$

\footnotetext{
145 See Goltz, Azerbaijan Diary, op. cit [134], chapter 21, ”The Lull Before the Storm”, pp. 348-365.

${ }^{146}$ Goltz, Azerbaijan Diary, op. cit [134], p. 365.
} 
The following events, those that brought Heydar Aliyev back to Baku, are somewhat difficult to disentangle; nevertheless it seems relatively safe to discard the theory that assumed Heydar Aliyev as an accomplice of Husseinov's from the start and as a Russian stooge. Husseinov's rebellion most certainly played into his hands, however. From the pieces that can be picked up, as Goltz does in his Azerbaijan Diary, it seems rather as if a Turkish hand was behind Heydar Aliyev. This may seem illogical as Elçibey was Ankara's man without doubt; however Elçibey was by no means an ideal leader for Turkey. Elçibey's erratic behavior and his total failure to understand the workings and tact of international politics, coupled with his utter inability to keep Azerbaijan together and to defend either the country against aggression or his own government's authority against rebels was very disappointing for Ankara. Several high Turkish officials in private express their mixed feelings with Elçibey, seeing him as a liability as much as an asset. In fact, put aside his difficulties in putting the country together, Elçibey was seen as too pan-Turkic and too obstinately anti-Iranian and antiRussian to actually further Turkish interests in the Caucasus and Central Asia. Elçibey's anti-Iranian rhetoric and the subsequent deterioration of Azerbaijani-Iranian relations to below the freezing point (see chapter 6) only heightened the existing Russian and Iranian fears of Turkish imperialism in

Figure Error! Unknown switch argument.: Heydar Aliyev the Caucasus and Central Asia without bringing about anything positive for Ankara, Azerbaijan being to chaotic to actually be of any immediate use for Turkey. Holding on to

Elçibey was a priority for Ankara only as far as his ouster would raise the specter of a pro-Russian leader taking control in Baku. ${ }^{147}$

But in early 1993, the situation in Azerbaijan was deteriorating so much that Ankara, as Thomas Goltz put it, 'started looking out for alternative horses to back'. ${ }^{148}$ And Heydar Aliyev, whose personal relationship with Süleyman Demirel had grown ever since they first met in Nakhjivan in 1992, was the best horse at hand. Goltz narrates how Aliyev on three occasions in the Spring of 1993 was pushed by Turkey to assume a more active role to prop up the Elçibey regime, but refused to be associated with it. But in June, the situation was critical and Demirel reportedly urged Aliyev to intervene. Aliyev nevertheless said he would do so only if Elçibey himself begged him to come. And, indeed, after another telephone call from Çankaya, Elçibey complied. The President nevertheless tried to save the situation by offering Aliyev the post of Prime Minister (a largely unimportant post at the time) in order keep control. However, both Aliyev and Husseinov were aiming higher. Aliyev refused the offer, instead expressing his interest instead in the post of speaker of parliament. On 13 June Isa Gambar resigned from the post, which he had been holding until then; two days later Aliyev was elected new speaker by the parliament with a safe majority of 34 against three; interestingly, Aliyev during this time referred

\footnotetext{
${ }^{147}$ Conversations with various high Turkish officials of the time, Ankara 1995 to 1997 and 1999.

${ }^{148}$ Goltz, Azerbaijan Diary, op. cit [134], p. 367.
} 
to Mutalibov as a traitor and to Husseinov as a madman, hence very clearly adding evidence to the fact that he was not the Russian 'agent' observer later called him. ${ }^{149}$

Husseinov nevertheless did not stop. He gathered his forces around Baku while foreigners evacuated; finally on 17 June the head of Azerbaijan's security ministries officially stated what everybody could observe: Surat Husseinov's advance on Baku would not be resisted. The same night, Elçibey left Baku, throwing in the towel and leaving for his native Nakhjivan; symbolically, and hardly coincidentally, Elçibey was to celebrate his one year in office the next day. By this act, he claimed to have sacrificed his own position to avoid bloodshed. His opponents simply contended that he had fled. As a response to this, Aliyev declared that he had taken over the functions of the President by virtue of his post as speaker of parliament. As Elçibey failed to present himself in parliament when asked to do so with a week's notice, the parliament could constitutionally strip him of his powers. In his place, Aliyev was elected care-taker President until elections were held; in fact his full title was 'Chairman of the National Assembly of the Republic of Azerbaijan and Reinvigorator of the Extraordinary Powers of President of the Republic. ${ }^{150}$ Thus Elçibey removed, the most direct obstacle to Aliyev's power had been removed. However this did not mean that he was safe in his chair. ${ }^{151}$

Surat Husseinov, for his part, had aspirations of his own. Thus a confrontation between Aliyev and Husseinov was likely, which would be to the disadvantage of Aliyev, who had no military to command over nor any consolidated control over any state organs. However he had something Husseinov did not have: A political experience comparable to anyone and a capacity for political calculation like no one else in the country, and connections in the establishment that he could reinvigorate. Husseinov initially wanted the Presidency for himself. However, he soon came to realize that this was not possible; furthermore the final loss of Agdere/Mardakert, the last remaining Azeri stronghold in Karabakh, might have made Husseinov less hungry for power, seeing that for the time being, being in charge meant being responsible in the case of military defeats, which in fact had been the major factor opening the way for Elçibey's demise. On 27 June, Aliyev reached an agreement with Husseinov, whereby the latter accepted the post of Prime Minister, the post having received drastically increased powers in the meantime. In fact the post was tailored for Husseinov's wishes, as he was given the defence, interior, and security ministries under his portfolio as well. On the $28^{\text {th }}$ already, Husseinov ordered some of his force to turn away from Baku and move to the front in Karabakh, where the Armenians were not late to exploit the events.

The fact that a Russo-Armenian military cooperation treaty was signed just before the start of the turmoil in Azerbaijan is often taken as another indication of the Russian hand: although generalizations are inherently dangerous, one seems in its place: There are no coincidences in the Caucasus. In the final analysis, it seems doubtless that Russia-whether the government or only certain state structures-was actually involved in the overthrowal of Elçibey. Husseinov was

\footnotetext{
${ }^{149}$ For an overview of the parliamentary debate that brought Aliyev to power and the intrigues surrounding the events, see the excellent and well-informed analysis in Goltz, Azerbaijan Diary, op. cit [134], chapter 22, ”The Crowbar — or Heydar Comes Home”, pp. 366-392.

${ }^{150}$ In Azeri, Azérbaycan Réspublikasínín Milli Meclisin Sédri vé E'spublikasínín Présidéntin Silahiyétlaríní Héyata Geçérin Héydar Élirzaoghlí Éliyév. See Goltz, Azerbaijan Diary, p. 407.

151 See Justin Burke, ” In Azerbaijan, Three Say: 'I'm in Charge'”, in The Christian Science Monitor, 23 June 1993.
} 
Russia's man, and either coveted the presidency for himself or would share power with Mutalibov in Moscow. But Aliyev, and Turkey, had succeeded in preventing Azerbaijan from becoming a Russian colony once again. Concessions would be made; but Azerbaijan remained independent and remained in reality, if not in appearance, more firmly than ever connected in an axis with Turkey.

In retrospect, it seems as if Aliyev used Russia's will to throw Elçibey out of power, and the hidden support for Husseinov, for his own purposes. Hence where Russia thought to have put a potentially friendly ruler in place in Baku, Aliyev, after making initial and necessary concessions such as joining the CIS and distancing himself rhetorically from Elçibey's overly pro-Turkish attitude, he never gave up Azerbaijan's sovereignty, and consistently refused, just like Elçibey had, to accept the stationing of Russian troops on Azeri soil. Moreover he quickly consolidated his own power so as to control the whole country personally. He eventually managed to get rid of Husseinov after an attempted coup by the latter, and became Russia's largest foe in the Caucasus, notably with the signing of the oil consortium in 1994. This led to a series of attempted coups and continued political instability, which Aliyev nevertheless managed to clear out with a mixture of luck, skill, and Turkish help.

\section{The Tide of the War}

The total chaos in Azerbaijan's capital naturally did not have any positive effect on the war in Karabakh. The Armenians were not slow to exploit the given opportunities, as the events in Baku further weakened the already weak Azerbaijani army and cast doubt upon the Azerbaijani government's ability to control the armed forces. Not even a month after Elçibey's fall from power, the Karabakh Armenians broke their unilateral cease-fire and initiated an offensive whose immediate consequence was to bring most of Nagorno-Karabakh into Armenian hands, with the seizure of Agdere/Mardakert on 28 June. ${ }^{152}$ Azerbaijan now controls Seeing the disastrous condition of the Azerbaijani forces, the Armenians decided to continue their offensive given this rare opportunity and directed their energy primarily at the Agdam region, a strategically located major Azeri settlement (with 150,000 inhabitants of which 50,000 in the city itself) to the East of Karabakh, but also at the regions of Fizuli and Jebrail to the South and Southeast of Karabakh. ${ }^{153}$ Within a few days, the massive attack on Agdam had broken through the Azerbaijani defence lines - which subsequently fled ahead of the civilian population — and by 4 July the city was under siege. ${ }^{154}$ After a long siege and heavy fighting, the Armenians initiated a decisive attack on 21 July and routed the Azeri defenders, capturing the city on 23 July. The civilian population was forced to leave, and the city was burned and looted. ${ }^{155}$ As soon as Agdam was under siege, the Armenians concentrated troops on the Southwestern part of Azerbaijan, on the regions of Fizuli and Jebrail. ${ }^{156}$ The offensive on Fizuli started as soon as Agdam was secured. Fizuli was strategically immensely important to Azerbaijan, as it is the gateway to the strip of territory which passes South of Karabakh and stretches through the Jebrail, Qubatli, and Zangilan regions to the

\footnotetext{
152 See Reuters News Service, 5 July 1993.

153 See Lloyd's Information Casualty Report, 5 July 1993.

154 See Reuters News Service, 2-4 July 1993; Anatol Lieven's report in The Times, 6 July 1993.

${ }^{155}$ Reuters News Service, 21 July 1993; BBC Monitoring Service, 22, 24 and 26 July 1993; The Independent, 28 July 1993.

${ }^{156}$ See Reuters News Service, 5 July 1993.
} 
Armenian border, with Iran to the South. Now that the Armenians had secured control over Nagorno-Karabakh as well as the Lachin and Kelbajar areas linking the enclave with Armenia, their only security concern was the danger of this link being cut off by an Azerbaijani offensive. Such an offensive could, as long as the Zangilan-Fizuli strip was in Azeri hands, be conducted on two fronts, one from Zangilan in the South and another from the Ganja and Khanlar regions in the North. Such a geopolitical situation would naturally leave the Armenians of Karabakh in a considerably vulnerable position, as an arm stretching out of Armenia into Azerbaijan —an arm that could relatively easily be torn off. Hence it was strategically highly important for the Armenians, given the present unforeseen opportunity to seize this strip of land. According to one western diplomat in Baku, "I wouldn't describe the Armenian operations as an invasion. It's more like armed tourism. The Azeri government is a shambles and can offer virtually no resistance."

The offensive of Fizuli did not last long; the city with its population of 40'000 was forced to surrender on 23 August. ${ }^{158}$ Meanwhile, the town of Jebrail was the subject of fighting and was secured by Armenian forces shortly after the fall of Fizuli. At this point only fifteen kilometers separated the Armenian forces from the Iranian-Azerbaijani border; in October the situation became critical as they pushed southward to the Iranian border, seizing Zangilan. Thus refugees swam over the Araxes to Iran, were they were welcomed by Iranian Azeris. However the Iranian authorities, already overwhelmed by millions of refugees from Afghanistan and Iraq, were afraid that too much fraternizing between refugees and their citizens would lead to increased pressure on the government to intervene on Azerbaijan's side. Hence, the refugees were soon forced to return to Azerbaijan. The Iranians instead set up and funded refugee camps within Azerbaijan. Nevertheless, Iran strongly condemned the Armenian actions, and was reported to have amassed a significant number of troops on the border — a fact which in turn triggered the immediate reaction of Turkey, but also of Russia. ${ }^{159}$ The existence of major troop movement in Iran were nevertheless never corroborated by independent sources. ${ }^{160}$ Russia also warned the Armenian republican leaders that continued attacks would jeopardize bilateral relations. Nevertheless, the Armenians were obviously able to see through the bluff and indeed called it. The Armenians nevertheless did not move towards the Iranian border, probably for two major reasons. First of all, this would have entailed that approximately 80'000 Azeris would be trapped in the Zangilan and Qubatli regions and would have no option but to cross the Araxes into Iran, something which would necessitated an Iranian reaction of some sort, be it reluctantly. Secondly, this could have turned the spotlight on the region and spurred increased international involvement that might have jeopardized-although this is doubtful-Armenia from pursuing its objective of cleansing and occupying the Zangilan-Fizuli strip. The logical procedure the Armenians followed was to leave a short strip of land by which the civilians could escape into the Western Azerbaijan, and concentrate on securing control over the Qubatli and Zangilan districts. Again, the Armenians were interested in land, not in massacring the civilian population, since that would bring no benefit but only have a potential to alter the pro-Armenian world opinion in Azerbaijan's favor.

The remaining Azerbaijani forces in the North could do nothing else but try to divert the attention of the Karabakh Armenians by counter-attacking the Agdere/Mardakert region. The

\footnotetext{
157 Quoted by Hugh Pope in The Independent, 28 July 1993, p. 10.

158 See The Times, 24 August 1993.

159 See The Guardian, 3 September 1993.

${ }^{160}$ I am grateful to Thomas Goltz for pointing this out to me.
} 
strength of the Azerbaijani forces was however not sufficient for such a move, and they were instead forced to abandon Qubatli in the South to advancing Armenian forces. ${ }^{161}$ A cease-fire was announced by the Armenian forces, who basically needed to regroup and as it seems, wait for new supplies of arms and troops from Armenia. In the end of October, the cease-fire broke and Armenian forces rapidly seized the town of Goradiz on the Azerbaijani-Iranian border, just Southeast of Fizuli, thereby cutting the Zangilan region off from the rest of Azerbaijan. It was a $t$ this time that the Azeri refugees began fleeing into Iran. ${ }^{162}$ This Armenian move seems to have been caused by an apparent decline in Armenian strength to the East of Karabakh, as Azerbaijani forces showed signs of recovery in the Agjabedi region East of Agdam. ${ }^{163}$

At this point, an interesting fact is that the Azerbaijani forces encircled in the Zangilan region were reported to be shelling the Armenian republic's territory to the West, (the regions of Kafan and Megri) and not Karabakh Armenian forces to the North or East of them. This seems to point to the fact that the troops to invade the Southwesternmost corner of Azerbaijan were Armenian republican forces and not Karabakh forces. By the end of October, the Armenian forces had taken Zangilan and pushed back the remaining Azerbaijani forces to the Iranian border. Meanwhile, the civilian population that had resolutely refused to leave were forced to flee en masse over the Araxes into Iran. ${ }^{164}$ Meanwhile, around a thousand Iranian troops had been reported to have crossed into Azerbaijan at the beginning of September, establishing a presence in a nominally Azerbaijani-controlled buffer zone along the Araxes and then returned to Iran. ${ }^{165}$ This naturally led to worries in Moscow, but especially in Ankara, regarding the danger of an escalated conflict. 50'000 Turkish troops were amassed at the Armenian border, and the conflict was probably at its highest risk ever of escalation. ${ }^{166}$ This nevertheless did not prevent the Armenians from evicting all Azerbaijani forces and civilians from the entire Zangilan-Fizuli strip. The strip has since been controlled by Armenian forces, with the exception of smaller portions of the border including the town of Goradiz which did not fall into Armenian hands until later in 1994. At this point the Karabakh Armenians reached their maximum territorial extension, and the areas they control today are basically those that were conquered until the end of 1993. The ethnic cleansing systematically carried out on all occupied territories during the 1993 offensive resulted in a total of over half a million refugees in Azerbaijan, to be added to those that had arrived since the beginning of the conflict. ${ }^{167}$

Towards the end of 1993, however, Aliyev seemed to have restored some order in the army, and on 22 December the Azerbaijani forces initiated a large-scale counter-offensive, along the entire front-line, but particularly around the Agdere/Mardakert and Kelbajar regions, as well as in the East of Karabakh. ${ }^{168}$ Initially, the offensive was able to recapture some territories, in particular to the North of Kelbajar, and it seems that Russian support for the Azerbaijani forces had made this possible. Azerbaijan had joined the CIS and Aliyev was skillfully tempting Russia with the

\footnotetext{
${ }^{161}$ Interfax, 1 September 1993; BBC Monitoring Service, 3 September 1993.

${ }^{162}$ BBC Monitoring Service, 28 October 1993.

${ }^{163}$ BBC Monitoring Service, 29 October 1993.

${ }^{164}$ BBC Monitoring Service, 3 November 1993.

${ }^{165}$ BBC Monitoring Service, 6 September 1993.

${ }^{166}$ Hürriyet, 4 September 1993.

167 Tehran Times, 28 October 1993.

${ }^{168}$ BBC Monitoring Service, 1 January 1994.
} 
prospect of military bases, and was able to acquire Russian weaponry. (see chapter 4) However, this did not mean that Azerbaijan was allowed to gain the upper hand. The Azerbaijani offensive was soon halted, as regular Armenian army forces stepped into Azerbaijan again, this time in a larger scale than ever, to save the Karabakh Armenians from any setbacks. Thus in February 1994, the Azerbaijani counter-offensive were forced back, and lost most of its earlier gains; Armenian forces moved North from Agdere/Mardakert into the Terter region, only thirty kilometers Southwest of the strategically located town of Yevlah. ${ }^{169}$ On 26 February a Russianbrokered cease-fire entered into force, but this interruption in the hostilities was not to last long. In April, major fighting erupted in the areas of Agdere/Mardakert and Agdam, leading to another Karabakh Armenian offensive. Speculations have been aired that the Armenians attempted to seize Yevlah, which lies near a lake reaching up to the Georgian border, a move which would have cut Azerbaijan into two and separate Baku from Ganja, the second largest town. Whatever the case, the offensive failed but resulted in another 50'000 Azeri civilian refugees.

On 16 May, a new cease-fire was announced by Russian defence minister Pavel Grachev. Two months later, the defence ministers of Armenia and Azerbaijan, as well as the head of the Karabakh Armenians' armed forces, signed a document giving the cease-fire a legal basis. This cease-fire is still in force, having held ever since. However, it is important to note that artillery duels and low intensity conflict has gone on ever since at various scales. OSCE observers claim an average of one person a day has been killed along the front since 1994, amounting to over 1600 people by early $1999 .{ }^{170}$

${ }^{169}$ BBC Monitoring Service, 9 February 1994.

${ }^{170}$ I am grateful to Thomas Goltz for pointing this out to me. 
Figure Error! Unknown switch argument.: the Occupied Territories in Azerbaijan

Thus by any standard, the war in Karabakh led to the military victory of the Karabakh Armenians. Azerbaijan was plagued by international isolation, a weak and ill-equipped army, and internal turmoil during the whole war; this is the reason why the tiny Karabakh Armenian population, supported by three-million strong Armenia, could inflict such a humiliating defeat on the much more numerous Azerbaijani.

Armenia, for its part, suffered from none of the problems observable in Azerbaijan. They had a favorable world opinion—at least until the attacks in late 1993 — a motivated army equipped with modern weapons imported from the Middle East, and political stability. The main problem in Armenia was the desperate lack of energy. During winter, many houses could not be heated as no energy reached Armenia due to the Azerbaijani-Turkish embargo and internal trouble in Georgia. Nevertheless the Armenians managed to de facto alter internationally recognized borders by force, without even receiving a direct condemnation by any major power or organization except Turkey and to a lesser extent, Iran. Neither were any international sanctions even discussed. In this sense, the Armenian campaign was a clear-cut success.

\section{The Hard Road to Stability in Azerbaijan}

The first coup attempt that Aliyev had to face was that orchestrated by Husseinov in October 1994. Husseinov was obviously not content with his role as prime minister, and is alleged to have collaborated with the ousted president Ayaz Mutalibov, at the time living in Moscow, in trying to 
bring Aliyev down. ${ }^{171}$ The coup attempt came shortly after the signature of the 'deal of the century' $-a$ fact which has increased speculation on Russian (and Iranian) involvement. Husseinov acted mainly behind the scenes but is believed to have orchestrated the assassination of two high government officials while Aliyev was in New York attending a UN summit. ${ }^{172}$ As Aliyev returned to Baku, members of the interior forces (OPON) loyal to deputy interior minister Rovshan Javadov were arrested for the murders. ${ }^{173}$ This prompted a standoff with the OPON forces which captured the prosecutor general of the country. Aliyev denounced not only Javadov but also explicitly Husseinov and more implicitly Russia for the disturbances. ${ }^{174}$ Aliyev demonstrated his popularity by gathering over 10’000 supporters in front of the presidential palace, something which brought both Husseinov and Javadov to the open, denying Aliyev's accusations. ${ }^{175}$ By 5 October, Aliyev appeared in front of a crowd with Husseinov, publicly reprimanding him for the past days of unrest. The next day, Husseinov was sacked by Aliyev. ${ }^{176}$ Hence the coup attempt - which was very chaotic from the beginning - was thwarted and Husseinov fled to exile in Russia from which he was extradited to Azerbaijan in 1997. The one clear consequence of the unrest was the strengthening of president Aliyev's position, as his most powerful rival had been discredited and eliminated from political life. The ease with which this was achieved, nevertheless, led to speculations that Aliyev himself had provoked or engineered the unrest in order to sack Husseinov. ${ }^{177}$ Perhaps such allegations are somewhat exaggerated; however Aliyev was conceivably well-informed about events and in any case was prepared to respond and to capitalize on his popularity and charisma by rallying the people around him and hence preventing the rebels from advancing towards the presidential palace.

After Husseinov's rebellion, the largest threat to Aliyev's power was done away with. But contenders remained, the most threatening of these being Rovshan Javadov, with whom Aliyev had chosen to compromise, perhaps due to Javadov's relatively prompt decision to side with Aliyev as soon as it became clear the Husseinov-led coup would fail. In March 1995, however, Javadov again led a mutiny of his OPON forces, demanding Aliyev's as well as parliamentary speaker Rasul Guliyev's resignation. Aliyev reacted more harshly this time, ordering the army to attack Javadov's power base in Baku. After an unsuccessful attempt to storm the OPON barracks, the government troops finally stormed the headquarters, with over 50 casualties. ${ }^{178}$ Javadov himself was wounded and later died in hospital. ${ }^{179}$ Javadov's fate clearly served as a reminder to any would-be coup-makers of the dangers involved. Again, this time, there were speculations that Aliyev had provoked the showdown by cracking down on the organized crime activities led by

\footnotetext{
171 See Wendy Sloane, ”Azeri Government Thwarts a Putsch Linked to Oil Deal”, in The Christian Science Monitor, 6 October 1994, p. 5.

172 See Reuters News Service, 30 September 1994 and 3 October 1994; BBC Monitoring Service, 3 October 1994.

173 Lawrence Sheets in Reuters News Service, 4 October 1994.

174 See The Independent, 5 October 1994; The Times, 5 October 1994.

175 See Reuters News Service, 5 October 1994. For Aliyev's televised public address, see BBC Monitoring Service, 5 October 1994.

176 Itar-Tass and Reuters News Service, 6 October 1994.

177 See eg. Carey Scott in The Sunday Times, 9 October 1994.

178 The Independent, 17 March 1995; Reuters News Service, 15-18 March 1995; Los Angeles Times, 18 March 1995.

179 See The Washington Post, 18 March 1995.
} 
the Javadov clique. Ever since, Baku has been relatively calm and no further sizable dangers to Aliyev's rule have been recorded, unlike in neighbouring Georgia where president Shevardnadze has survived two well-planned assassination attempts.

\section{The De-Facto Integration of Karabakh into Armenia}

The territories that fell under Armenian control, in particular the areas of the former NKAO, slowly but steadily became integrated as a part of Armenia. For every practical purpose, Nagorno Karabakh has become a part of Armenia, thus a practical success as far as its quest for secession from Azerbaijan is concerned. The only obstacle is that no political settlement can be reached with Azerbaijan to cement this state of affairs. Quite to the contrary, President Aliyev has repeatedly stated that "if our lands are not freed, we will have to free them ourselves".

For the time being, the Karabakh Armenians are working on improving their communications with Armenia; there being no rail or air links, a road over the mountains to Armenia is the only life-line of the enclave. The Diaspora has funded an 11 million dollar project to make this winding mountain road safer and able to carry higher amounts of goods. ${ }^{180}$ Interestingly, the goods that reach Karabakh are most often originating in Iran, which has an important border trade with Armenia. On the border between Armenia and what used to be parts of Azerbaijan, there is no demarcated border or passport controls. Officials even admit that in the economic and financial field, Karabakh and Armenia are actually one entity, just as their unified budget. And as long as there is no negotiated solution to the conflict, the integration of Karabakh into Armenia means that it will be increasingly difficult for Azerbaijan to ever regain control of these territories by diplomatic means. Thus the only hope for Azerbaijan is a military solution; in fact the present Azerbaijani attitude seems to confirm this assumption. For the Azeris, far from pressing the international community or attempting to resolve the conflict through active diplomacy, are mainly doing nothing. Thus it seems likely that they are anticipating oil revenues, which in turn would enable the building up of a large and well-equipped army, to be able to press for a resolution on their own terms, in face of an international environment where they would not receive any support for their negotiating position. Thus the attitude of the international community may be conducive to renewed warfare in the not too distant future. A deeper analysis of this problematic in a regional perspective is undertaken in chapter nine.

${ }^{180}$ See International Herald Tribune, 20 September 1996. 


\section{4}

\section{Russia: the Dishonest Broker}

The most direct consequence of the dissolution of the Soviet Union for the Caucasus was the achievement of independence for the three South Caucasian states of Armenia, Azerbaijan and Georgia. Much like had been the case in 1918, the Caucasian states were set free of Russian control because of Russia's more pressing domestic problems and issues. In 1918, the Bolshevik revolution needed to be consolidated before the new leadership could embark on a reconquest of the territories ruled by Czarist Russia; in 1991, the new liberal democratic Russia needed to be built and consolidated, necessitating a loosening of the grip on the peripheries. At both occasions, Moscow recognized the independent Transcaucasian states of Armenia, Azerbaijan and Georgia, and for a short period did not have any outright and direct ambitions on them. However, again both in 1920 and in 1993, that is two years after the respective declarations of independence of these states, a drive to reassert control over these states emerged. While the two periods hence show distinct similarities, the difference between them are equally important. Most importantly, while Bolshevik Russia in 1920-21 overran the Caucasian states militarily and incorporated them forcefully into the emerging Soviet Union, Russia in the 1990s was both unable and unwilling to employ such a tactic. Nevertheless, whereas Russia has not tried to conquer the South Caucasian states in an overt way, it has nevertheless employed many different tactics at its disposal to sustain and expand its influence on and control over this region. In this framework, it is necessary to differentiate between the North and South Caucasus. The North Caucasus, of course, is a part of the Russian Federation under international law, whereas the South Caucasus consists of three independent states. The patterns of Russian intervention must hence be judged differently in the two regions; Russia should be expected to have vertical relations with its constituent units, the North Caucasian republics, whereas it ought to keep horizontal relations - that is, on a formally equal level despite its greater size, resources and power — with the South Caucasian states. This said, however, evidence shows that circles in the Russian administration have less than fully acknowledged and accepted the independence of the South Caucasian states, instead continuing to see them as territories that need to be brought under some form of Russian influence.

Different branches of the Russian state in the early 1990s had widely divergent understandings on how to formulate Russia's policies towards the South Caucasus, and moreover these different branches conducted and implemented different policies when in disagreement. The policy of official Moscow to the Caucasus, then, underwent distinctive changes during the 1990s, which had significant impact on the region. This chapter begins by analyzing the formulation of Russian foreign policy towards the Newly Independent States (NIS) of the former USSR, and especially towards the Caucasus. Having done this, an attempt is made to map the patterns of Russian intervention in the South Caucasian states and in the relations between them. Then the complex issue of Russia's relations with the North Caucasus is viewed, before treating the question of the development of the nature of the Russian Federation and its prospects in the region. 


\section{The Russian Foreign Policy Debate and Foreign Policy Goals in the 'Near Abroad'}

Over the years that have passed since the dissolution of the Soviet Union, the Russian foreign policy has gone through several readily discernible major phases. The immediate reaction to the dissolution of the empire that Moscow ruled was a state of confusion that lasted though the initial phase of the building of the Russian state. Indeed, Russia needed to define itself before defining any policy orientation towards its former dominions. De Facto, this meant that Moscow relinquished control over the three South Caucasian republics both politically and militarily. However, there was no consensus in Russian political circles on this development. Official Moscow initially paid little attention to the former Soviet Union, instead attempting to direct Russia towards the west; opposition to this policy nevertheless grew quickly.

\section{The Initial Western Orientation and its Critics}

The body that had a prerogative in defining Russian foreign policy in the immediate aftermath of the Soviet Union's dissolution was the ministry of foreign affairs of the Russian Federation: in fact, Ukraine, Belarus, Kazakhstan and Russia had had foreign ministries of their own since 1944, which nevertheless did not have any real function whatsoever. In fact, analysts have brought forward the assertion that in Yeltsin's power struggle with Gorbachev, the RSFSR platform became his primary base on which he staked his political future. Following this logic, the price that Yeltsin had to pay to unseat Gorbachev was the weakening of union institution vis-à-vis republican ones, and ultimately the dissolution of the union. With no Soviet Union, Gorbachev's power base would disappear; and in the event that the USSR be transformed into a loose confederation, as was the plan before the August 1991 coup, the function of the 'union' authorities would be severely diminished in favor of Russian and other republican organs. ${ }^{181}$ Hence in the aftermath of Russia's declaration of sovereignty-which sent shock waves throughout the union-Russia began to formulate a foreign policy of its own, distinct in many ways from the one of the other power center in Moscow, the union authorities. Gennadiy Burbulis, foreign policy advisor to Yeltsin, noted in April 1991 that learning from the European experience was crucial for the resolution of Russia's pressing domestic problems. ${ }^{182}$ The consequence that follows from this picture of the early Russian —as opposed to Soviet-foreign policy is a set of priorities which made it anti-Soviet, inward-looking, pro-Western, and giving the peripheral republics of the union little priority. This is not to say that the Russian Federation leadership in any way sought the total dissolution of the Soviet Union. Indeed, Kozyrev in an interview stated that he 'had not dreamed of' the dissolution of the Soviet Union, having in mind however a 'commonwealth or integrated structure of more or less independent states' in its place. ${ }^{183}$ Johan Matz finds that Kozyrev seemed to envisage the future of the USSR along the lines of the European Union: voluntary integration to promote peace and prosperity would replace

\footnotetext{
${ }^{181}$ See, eg., Roman Laba, ”How Yeltsin’s Exploitation of Ethnic Nationalism Brought Down an Empire”, in Transition, 12 January 1996.

182 Ibid, quoting an interview with Burbulis in Rossiiskaia Gazeta of 20 April 1991.

183 See ”An Interview with Russian Foreign Minister Andrei Kozyrev”, in RFE/RL Research Report, vol. 3 no. 28, 15 July 1994, p. 36.
} 
the imposed ideological base. ${ }^{184}$ The Russian leadership hence underestimated the centrifugal forces in the non-Russian republics of the union.

The Russian state that was being created by this process was in 1991-92 in the process of building its institutions and securing the control over its territory. Its foreign policy was dominated by one of the two major schools of thought in Russia at the time, the reformist school termed 'Euro-Atlanticist' (as opposed to a more imperialistic 'Neo-Eurasianist' school) by Mohiaddin Mesbahi. This school of thought held that rather than needing to coerce the former Soviet republics to fall under Russian influence as had been the case in the past, Russia would be welcomed as a natural leader by Central Asian and Caucasian states in particular. Mesbahi summarizes the policy's implications as follows:

A much closer overall security relationship with the West and rather a cooperative policy in the Persian Gulf/Southwest Asian region. The US preponderance in the Persian Gulf will not be questioned, Iran will be kept under a watchful eye, while the role of Turkey as the western endorsed model for the region will, with some reservations, be accepted. No controversial 'and out of line' stand will be adopted that might jeopardize the strategic direction of Russia for inclusion in the 'civilized club'. Russia wants to be treated as a normal western great power with identical interests. ${ }^{185}$

As concerns the countries of Central Asia and the Caucasus, the new Russian policy was correctly interpreted as a drastic alteration of priorities and hence the creation of a power vacuum there. In fact, the Russian leadership totally neglected these regions: American foreign minister James Baker visited the region before Kozyrev did, and the US, Turkey and Iran rapidly established embassies there. Militarily, Russian troops were pulled back from most states, and the North Caucasus became a frontline district.

Kozyrev initially may have viewed the advances of other states in the region as completely natural—but the majority of analysts in Moscow did not. The main problem of this policy, of course, was the very meager political ground on which it was based. Far from enjoying a consensus in Russia, many and soon most political forces viewed it as a surrender to the west and particularly to the United States. The policy, in fact, remained dominant only as long as the Russian foreign ministry retained a dominant role in the formulation of foreign policy. As Matz has observed,

The Russian foreign ministry in the autumn of 1991 found itself in a position where its relative influence over the formulation of foreign policy was reaching an unprecedented scale. ... The rivalling bureaucratic organisations that had used to struggle with the MFA over the influence of foreign policy making had thus vanished and the Russian MFA accordingly enjoyed a position where its officials were more or less free to define the parameters for a new post-Soviet language of national interest. $^{186}$

Soon, however, the opposition to the foreign ministry's policy and its dominant position grew. The parliament, in particular, by April 1992 chastised the ministry for what it deemed its

\footnotetext{
184 Johan Matz, ”Analysis of Russian Foreign Policy mid-1990 till mid-1992”, (draft version presented at the department of East European Studies, Uppsala University, 21 January 1999) in Constructing Foreign Policy Discourses: Russia and the Newly Independent States 1990-95, forthcoming Doctoral Dissertation, Department of Government, Uppsala University.

185 Mohiaddin Mesbahi, ”Russian Foreign Policy and Security in Central Asia and the Caucasus”, in Central Asian Survey, vol. 12 no. 2, 1993, pp. 184-185.

${ }^{186}$ Matz, ”Analysis of Russian Foreign Policy...”, op. cit [184], p. 26.
} 
incapacity to formulate a policy on the Russian Diaspora in the NIS; the events in Moldova were the main contentious issue at the time. The ministry of defence was also an increasingly vocal critic of the foreign ministry; as all non-Russian republics 'grabbed their share' of the military forces on their soil - in particular Ukraine - the Soviet military was in fact being dismantled, seemingly without protests from the MFA. Meanwhile, the assumptions on which the Atlanticist policy was based did not hold. Russia's abrupt economic decline continued, structural readjustment was slow, public international aid was ineffective while private investment was insignificant. As the government's failure to create a new, 'westernized' Russia led to the increasing popularity of views that envisaged the 'restoration of the importance of that instrument of state policy that had been prominent in both Tsarist Russia and the Soviet Union: military power' ${ }^{187}$ The liberal, westernized clique lost much of its initial popular trust, while conservative forces became increasingly popular and powerful. As a result, the conservative forces began to reassert their influence over foreign policy making, pressuring the President. These included the armed forces, the military-industrial complex, and the security services such as the KGB which had escaped reform. ${ }^{188}$

The conservative forces believed that the success of Russia's transition was dependent upon the restoration of Russia's role in the world. The emphasis on relations with the West and the ensuing neglect of the NIS, the Middle East and Asia are rejected as concessionary politics. NeoEurasianism does not agree on the Atlanticist view of foreign policy as based on domestic factors; instead, they see the two as interdependent, none clearly superior to the other. Moreover, the survival of geopolitics as a defining factor of international relations is stressed: Kozyrev's claims of a qualitatively new international environment are rejected. Proponents of this particular point have included Yevgeniy Primakov, then head of the security agency. The view of the West is not necessarily hostile but certainly non-euphoric. ${ }^{189}$ In a sense, this view argued for balance in a hitherto unbalanced foreign policy.

\section{The Return of Imperial Attitudes and The 1993 Security Doctrine}

The effects of the strengthening of this 'Eurasianist' worldview and the correspondent weakening of the Atlanticist position was soon reflected in government. In December 1992, the reformist prime minister Yegor Gaidar was replaced by centrist Viktor Chernomyrdin, whose main allegiance lies in the Oil and Gas industrial complex where he had based his career. In Stockholm, Kozyrev 'rudely awakened the slumbering audience of his CSCE colleagues by denouncing western interference in the Baltic states, telling the conference to keep its nose outside the territory of the former Soviet republics, demanding an end to UN sanctions against Serbia and stating that Belgrade could count on full military support from Russia'- ${ }^{190}$ only to claim to have appeared as a hardliner to make his audience aware of the dangers of failing to support his regime. The message, nevertheless, had come through. Kozyrev's and Yeltsin's later statements corroborate the fact that a policy shift had begun to occur by mid-1992. In early January 1993,

\footnotetext{
${ }^{187}$ Hannes Adomeit, ”Russia as a 'Great Power' in World Affairs: Images and Reality”, in International Affairs, vol. 71 no. 1,1995 , p. 55.

${ }^{188}$ See John B. Dunlop, The Rise of Russia and the Fall of the Soviet Empire, Princeton University Press, 1993, pp. 297-301.

${ }^{189}$ Mesbahi, ”Russian Foreign Policy and Security...”, op. cit. [185], pp. 187-188.

190 Adomeit, ”Russia as a 'Great Power’”, op. cit. [187], p. 45.
} 
Yeltsin heavily criticized US bombing of Iraq, and intensified military sales and ties to Iran, and asserted Russia's primacy in the post-Soviet space. ${ }^{191}$ During 1993, then, Yeltsin's government moved in the direction of the conservatives, but retained a balanced policy and kept up relations with the West roughly at similar levels as before. Meanwhile, the confrontation between Yeltsin and the conservative parliament was brewing, and ended in Yeltsin ordering the army to crackdown on the Supreme Soviet building in October after the parliament had refused to be dissolved. Yeltsin's apparent victory was undone by a stronger reliance on and influence of the military in his rule, and by the election of an equally conservative Duma in December. These developments intensified Yeltsin's move towards a more assertive and revisionist foreign policy.

In November 1993, a new Russian military doctrine was signed by President Yeltsin. ${ }^{192}$ The decree noted that Russia does not declare any country its enemy; however it identified threats to its security, including local wars near Russia's borders, expansion of military alliances, and discrimination of Russian citizens abroad. Moreover, the doctrine pays special attention to the stability of 'regions directly bordering the Russian Federation'. As Richard Staar among others has concluded, this implies that Russia 'asserts a sphere of influence that coincides with the one maintained by the USSR. ${ }^{193}$ This intentions was made clear by the provisions in the doctrine that called for the Russian military to deploy troops on the territories of CIS members, 'either together with units of another state or as exclusively Russian formations at their own separate bases', ${ }^{194}$ provisions that were actively followed by the Russian leadership since — but also before — the inception of this doctrine; in fact the draft of the doctrine existed months before President Yeltsin actually signed it. As Stanislav Lunev, a former colonel in the GRU has observed,

\begin{abstract}
The adoption of this doctrine had a short and not very attractive history. The military doctrine prepared by the Defense Ministry lay for half a year on the desk of the president, who refused to sign the document until October 1993, the month of the bloody suppression of the first Russian parliament by the executive branch. After receiving the support of the military hierarchy and elite military units of the Moscow Military District in his fight against parliament, the Russian president approved the military doctrine as a means of paying off the debt he now owed to military leaders.
\end{abstract}

As far as the Caucasus is concerned, Elizabeth Fuller has called the period from independence until early 1993 a period of picking up the pieces. That is, a period of limiting the damage caused by the dissolution of the Soviet Union, in practice by embracing the one country that was willing to remain within a Russian sphere of influence: Armenia. Fuller then identifies a second phase, accordingly corresponding roughly to 1993, of aggressive reintegration-in practice compelling Azerbaijan and Georgia to join the CIS, the details of which will be discussed below. Finally, Fuller, writing in the Summer of 1996, terms the period 1994 to the time of writing a period of consolidation of the influence acquired in $1993 .{ }^{195}$ While this analysis was certainly correct at the time of writing and shed light on the matter, it seems appropriate in retrospect to limit the period of consolidation to ranging from early 1994 until the middle of 1996, and the period from August

\footnotetext{
${ }^{191}$ Robert O. Freedman, ”Russia and Iran: A Tactical Alliance”, in SAIS Review, vol. 17 no. 2, 1997, pp. 93-109, here at p. 95.

192 See Krasnaya Zvezda, 19 November 1993, for an abridged version of the doctrine.

193 See Richard F. Staar, ”Moscow’s Plans to Restore its Power”, in Orbis, vol. 40 no. 3, Summer 1996, p. 376.

${ }^{194}$ Ibid, p. 376

195 See Elizabeth Fuller, "Russia and the Caucasus", in Ingmar Oldberg, ed., Priorities in Russian Foreign Policy: West, South or East, Stockholm: Swedish Defence Research Establishment, 1996.
} 
1996 until the present a gradual retreat. Russian interests in the region can be summarized as follows.

The South Caucasus forms a buffer zone between the Russian North Caucasus and the Islamic World to its South; in particular, the region is adjacent to Turkey and Iran, two states whose influence Russia sees as challenging to its own role. Among these two states, the Atlanticist view saw Turkey as a lesser evil compared with the specter of radical Islam emanating from Iran. The later dominant conservative view nevertheless correctly noted that Iran's ambitions were limited and in fact commensurate with Russia's insofar as both states viewed it as a priority to prevent the rise of Turkish influence. The conservative forces in Russia see Turkey as a much larger threat than Iran for two main reasons: first, Turkey in 1992 immediately capitalized on its linguistic and ethnic ties with the Turkic peoples of Central Asia and the Caucasus to boost its influence in the region at Russia's expense; and second, Turkey has a large and increasingly powerful military, which remains unchecked by political forces. As will be seen in chapter 5 , Turkey considers itself to have one of the strongest conventional military capabilities in the world, and seems to think that these capabilities can outweigh Russia's in the regional context. Furthermore, the South Caucasus is a region where Russia, as Fuller notes, feels vulnerable. ${ }^{196}$ The region borders Russia's unruly North Caucasus and the Caucasian states, as well as foreign powers, can have a destabilizing influence on this volatile part of Russia. Moreover, the South Caucasus is either the bridge or barrier for Russia's relations with the Middle East. Under Russian influence, the region would enable Russian relations with the Middle East; under the influence of other states, it would prevent it. The South Caucasus is also a zone of important economic interests: the oil of Azerbaijan and the possibility of the Caucasus transporting Central Asian oil westwards add to the geopolitical and geo-economic importance of the region. However the politics of oil go beyond this. The South Caucasus is the crucial western conduit to Central Asia. If controlled by Russia, it enables Moscow to control the amount of western influence in the geopolitically crucial region between Russia and the volatile Afghanistan and Pakistan, the rising China, and the luring India. In the opposite case, Russia could be exposed to security threats such as political Islam: Russian analysts have warned that the Islamic movement that spread from Afghanistan to Tajikistan in the 1980s and early 1990s might — if not checked—spread into the Muslim regions of Russia. The specter of political Islam rising in Tatarstan, 500 kilometers from Moscow, has been painted as an example of this threat despite the very dubious prospects of such a development, to say the least.

\section{The Climax: The Subduing of the Transcaucasus and the War in Chechnia}

In the middle of 1993 - that is, barely a year after the beginning of the policy shift - the assertive policy in the South Caucasus based on the motivations summarized above seemed to pay off. It is useful to remember at this point that the Russian policy towards the Caucasus was by no means unified at this point in time. Not only did different power centers have different opinions on the priorities of Russian foreign policy, they also actively pursued the policies they deemed appropriate. For example, Fuller notes that 'the Russian foreign ministry, the Defence ministry, and the Duma, had separate agendas in Georgia with regard to the Abkhaz conflict, and ... the

${ }^{196}$ Ibid., pp. 77-78 
Russian Foreign Ministry and the energy lobby had, and still have, diverging agendas with regard to the Caspian'. ${ }^{197}$

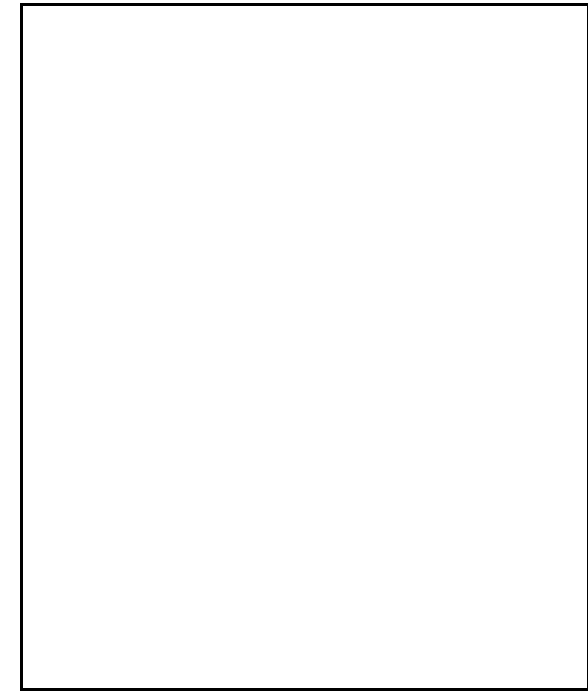

Figure Error! Unknown switch argument.: Boris Yeltsin

As a result of the patterns of intervention that are analyzed in further detail below, the conservative forces in Russia during the course of 1993 were successful in bringing Azerbaijan and Georgia 'into the fold'; both states reluctantly entered the CIS in Fall 1993. Faced with the alternative of disintegration, Georgia was forced to accept Russian border guards on its Turkish border, whereas Azerbaijan staunchly refused any Russian military presence on its territory, despite its resounding defeat in the Karabakh war. Russian control in the Caucasus was on the verge of being re-established; Azerbaijan's stance needed to be altered, but the country was brought under a semblance of Russian control; Surat Huseinov, an ally of Russia's, was its prime minister. Only one element of irritation —and a sizable one — was left: the Chechens in the North Caucasus with their erratic and virulently antiRussian leader, Jokhar Dudayev. With the other independent-minded republic within Russia-Tatarstan — brought under control by a treaty on the devolution of power (which has been considered unfavorable to the Tatars ${ }^{198}$ ) in February 1994, Moscow could now concentrate on Chechnia. It is no coincidence that the situation in Chechnia turned for the worse starting with the Spring and Summer of 1994. The only problem was that Chechnia could not be manipulated by Russian subversion as had been done in Georgia and Azerbaijan; the Chechen opposition was unsuccessful in toppling Dudayev.

As he went to the Budapest summit of the CSCE in early December 1994, Yeltsin's rhetoric and policy had changed considerably: Yeltsin now spoke of the risk of a 'cold peace' developing between Russia and the West. ${ }^{199}$ Only days later, the Russian army entered Chechnia. This clear and discernible pattern of a gradual increase in the influence of conservative powers over Russian foreign policy-making did not stop here, however. Russia in the course of the 1995 increased its criticism of NATO expansion and developed its relations with Iran and Iraq considerably, in spite of loud American protests. ${ }^{200}$ In November 1995, defence minister Grachev made public that Russia would not abide by the accord on Conventional Forces in Europe limiting the level of

\footnotetext{
${ }^{197}$ Ibid., pp. 75-76.

198 Marie Bennigsen Broxup, “Tatarstan and the Tatars”, in Graham Smith (ed.) The Nationalities Question in the Soviet Union, London: Longman, 1996, pp. 85-86.

199 "Yeltsin's Warnings at CSCE”, in RFE/RL Daily Report, 6 December 1994.

200 "Moscow Signs New Nuclear Accord with Tehran”, in Jamestown Monitor, 25 August 1995. ”Russia, China Reportedly Enabling Iran to Build The 'Islamic Bomb”,', Jamestown Monitor, 27 September 1995; "Russia to Defy U.S. on Nuclear Deal with Iran”, Jamestown Monitor, 7 September 1995; "Kozyrev Calls for Easing Sanctions on Iraq", in Jamestown Monitor, 6 June 1995; ”Russia Setting Stage for Shelving Iraq Sanctions?”, Jamestown Monitor, 1 September 1995. Also Freedman, ”Russia and Iran...”, p. 96.
} 
armaments in the Caucasian military district. ${ }^{201}$ Moreover, Yeltsin announced that Russia desired the stationing of Russian border troops along all external borders of the CIS. ${ }^{202}$ As Yeltsin, despite this change of policy faced a defeat in the parliamentary elections of December 1995, he resolved to sack the near-entirety of the reformist and pro-western members of his cabinet, appointing in place of Kozyrev the Middle East expert Yevgeniy Primakov, a known friend of the Iraqi regime. $^{203}$

\title{
Patterns of Intervention
}

At the beginning of 1993, Russian prospects in the Caucasus were gloomy. Neither Georgia nor Azerbaijan were members of the CIS; Georgia had never been part of the organization, and Azerbaijan had withdrawn under Abülfaz Elçibey's anti-Russian policies. Both countries were trying to escape Russian influence; Georgia had difficulties finding a sponsor abroad, its courtship of the West not having paid off. Azerbaijan, however, was actively appealing to Turkey—not without response. To the North, Chechnia was ruled by Jokhar Dudayev, withstanding virtually all covert attempts by Russia to overthrow his regime and de facto independent. To trace back a date when Russia's territorial control southward had been weaker, one needed to go back to the late eighteenth century; Russia desperately was clinging on to the military bases it kept in Armenia and Moldova. But one circumstance offered a possibility to alter this state of affairs: the ethnopolitical conflicts on the territory of Georgia and Azerbaijan. In fact, a clear pattern of Russian intervention into the affairs of the NIS can be observed, in particular in the cases of armed conflict on their territory. Stephen Shenfield has summarized Russian policy as follows:

\begin{abstract}
Russia first helps the side it favors up to the point at which a politico-military result that it considers satisfactory has been achieved. It then shifts to the role of an impartial peacekeeper, prepared to use force even against those maverick extremist elements of the previously favored side who are determined to fight for a result better than the one secured for them by Moscow. ${ }^{204}$
\end{abstract}

Russian responses to the evidence presented of heavy weapons suddenly coming into the hands of rebels in Georgia, Moldova, or elsewhere have always received the same answer: these weapons were stolen from Russian arms depots. In this context Hill and Jewett's conclusion is worth mention:

If it is true, then Russian weapons must be the most poorly guarded in the world and Russian troops must be easily intimidated by local militias. Even within its own borders the Russian army seems incapable of holding on to its equipment. ${ }^{205}$

\footnotetext{
201 "Grachev: Russia Not Ready to Honor CFE Treaty”, Jamestown Monitor, 15 November 1995; Analysis in Stanislav Lunev, "Russia Balks on the CFE, Threatening Regional Security”, in Jamestown Prism, vol. 1 no. 24, 17 November 1995.

${ }^{202}$ For these developments see ”Moscow Presses Baku On Border Troops”, Jamestown Monitor, 30 May 1995; ”More Russian Troops for Ajaria”, Jamestown Monitor, 10 July 1995; ”Russian Officers Command Kyrgyz Troops on Kyrgyzstan Border”, Jamestown Monitor, 14 June 1995.

203 'A Special Correspondent' (Anonymous), ”Russia: A Time of Turmoil and Change: The Re-Making of the President”, in Jamestown Prism, vol. 2 no. 2, 26 January 1996.

${ }^{204}$ Stephen D. Shenfield, ”Armed Conflict in Eastern Europe and the Former Soviet Union”, in Thomas G. Weiss, ed., The United Nations and Civil Wars, Boulder: Lynne Rienner, 1995, p. 43.

${ }^{205}$ Fiona Hill and Pamela Jewett, "Back in the USSR": Russia's Intervention in theInternal Affairs of the Former Soviet Republics and the Implications for United States Policy Toward Russia, Cambridge, Mass:
} 
Naturally one factor has been that Russian troops at all levels in the peripheries of the former Soviet Union have been making a fortune out of selling the arms of their regiments to the highest bidder; there are even reports of whole units serving as mercenaries in these local wars.

During the late Soviet era, in particular 1990 and 1991, the Kremlin was relatively openly siding with Azerbaijan in the Nagorno-Karabakh conflict. Azerbaijan was the party which advocated the status quo, whereas Armenia embodied the revisionist forces of the union. Armenia, and Georgia were the republics of the South Caucasus that conducted independent policies; Azerbaijan remained firmly in the soviet camp. Although the Popular Front was formed at roughly the same time as the Armenian National Movement, it did not acquire a position of power until late spring 1992, whereas Ter-Petrosyan assumed power already in August 1990. Azerbaijan made no movement toward independence until the aftermath of the August coup 1991, in opposition to Armenia which in late 1990 had renamed itself 'Republic of Armenia' and asserted its continuity with the Armenian Democratic Republic of 1918-20. Armenia boycotted the March referendum on the preservation of the Soviet Union and resolutely moved toward secession. With independence, Armenian leaders initially distanced themselves from Russia, and hoped for a rapprochement with Turkey. However, as the difficulties in the Turkish-Armenian relationship became apparent (see chapter 5), Armenia was made abruptly aware of its geopolitical situation. As Nikolay Hovhannisyan notes,

the Armenian leadership began to understand that further change for the worse of the relations with Russia and the preservation of tension between the two countries is not in the interests of Armenia. The geopolitical situation of Armenia differs principally from that of Azerbaijan, as well as of Georgia. In this situation to continue to distance Armenia from Russia and to remain vis-a-vis with Turkey, who does not conceal its hostility towards us could mean great danger to the national security of Armenia. That is why at the beginning of 1992 the Armenian government adopted a new policy towards Russia. It decided to normalize its relations with Russia and to cooperate with that state in the political, economic, and if necessary, military fields.

And indeed, Armenia saw it 'necessary' to extend cooperation in the military field. It was even a priority issue. Armenia was the only South Caucasian state to join the CIS and its Mutual Security Pact willingly, which it did on 16 May 1992. If the assertion that 'there are no coincidences in the Caucasus' is to be trusted, the fact that the Armenian offensive on Lachin and Shusha took place on 17 May is interesting, to say the least. Four days later, an agreement was signed regarding the continued stationing of Russian troops in Armenia. ${ }^{206}$ In Azerbaijan, the pro-Soviet Mutalibov regime had pursued a pro-Russian policy very much to the dismay of the people-public opinion having turned increasingly anti-Russian after the January 1990 military intervention — and was deposed in the aftermath of the Khojaly massacre of February 1992. Mutalibov was blamed for the military setbacks, deemed to have deliberately stalled the creation of a national army. ${ }^{207}$ However, the Azeri political situation only stabilized in June, with the Popular Front asserting power through the election of Abülfaz Elçibey as President. This meant a serious worsening of

Harvard University JKF School of Government, Strengthening Democratic Institutions Project, January 1994, p. 51.

${ }^{206}$ Hill and Jewett, ”Back in the USSR”, op. cit. [205], p. 10.

${ }^{207}$ See eg. Shireen Hunter, "Searching for New Neighbours", in Ian Bremmer and Ray Taras, eds, New States, New Politics—Building the Post-Soviet States, Cambridge University press, 1997, pp. 448-49. 
relations with Russia, which together with Iran vehemently opposed Elçibey's pro-Turkish policies.

Since mid-1992, coinciding with the policy shift in Moscow, Russian relations with Yerevan have deepened considerably whereas its ties to Baku have gone from bad to worse, with occasional thaws. Regarding actual intervention in the war, both sides have claimed Russian troops aided the other, both by providing weapons and by supplying army units and soldiers. Overwhelming evidence exists of the participation of Russian individuals as mercenaries on both sides in the war, as well as representatives from other countries - especially Afghan Mujahedin in the case of Azerbaijan. Although such instances in no way directly implicate the Russian government, the fact that many of them were regular soldiers — or even whole units — of the Russian $4^{\text {th }}$ and $7^{\text {th }}$ armies, based in Azerbaijan and Armenia respectively. (The rank and file of the $7^{\text {th }}$ army is thought to be composed of between 60 and 80 percent local Armenians; the figure for the officer corps is $20-30 \%{ }^{208}$ the Azeri component of the $4^{\text {th }}$ army is nevertheless comparatively low.) The case of the $366^{\text {th }}$ motorized rifle regiment based in Stepanakert provides an example. As noted earlier, both Azerbaijani and independent sources assert that entire formations from the $366^{\text {th }}$ regiment supported the Armenian war effort in February 1992, notably during the Khojaly massacre, only to be retracted the next month. However, when being pulled out of Karabakh, large parts of the regiment, having a significant ethnic Armenian component, joined forces with the emerging Karabakh Armenian army. ${ }^{209}$ Finding direct evidence of Russian involvement is difficult. The condition of the military was such that isolated Russian soldiers on active duty may very well have joined either side for profit. Perhaps pushing the argument a little, one might imagine entire smaller units doing so. But it is difficult to imagine this happening without the knowledge of the superior officers; and again, there are few reports of soldiers being prosecuted for selling their weapons or defecting. While investigating Russian intervention, the words of Thomas Goltz are in their place: 'Finding a smoking gun is difficult, though there are bullet cases lying all around'. Indeed, eye-witnesses from Khojaly, as well as Azeris and Turkmens having served in the $366^{\text {th }}$ regiment en masse testified to the identity of some of their assailants: Russian and Armenian officers and soldiers of the $366^{\text {th }}$ regiment. ${ }^{210}$ Goltz suggests an interesting interpretation of the Khojaly events. According to a German-Armenian photographer that had traveled with Armenian units prior to and during the events, the participation of dozens of tanks and APCs from the $366^{\text {th }}$ in their attacks on Khojaly had been a welcome surprise. In other words, it was unexpected. Most civilians were nevertheless not killed and mutilated during the attack but in its aftermath, as they fled the town. Most observers, as well as Azerbaijani sources naturally assumed that the Armenians had carried out the massacre; in an example of bad taste, the Armenians contended that the Azeris had killed and mutilated their own people - much like the Georgians were said by Russia to bomb their own people in Sukhumi. The participation of the $366^{\text {th }}$ regiment in the event nevertheless raises the question of its reasons to participate in a massacre. If either by sympathy for the Armenian side or for anger towards the Azerbaijani - the regiment was reportedly shelled by Azerbaijani artillery-large parts of the regiment joined forces

\footnotetext{
208 See Elizabeth Fuller, "Paramilitary Forces Dominate fighting in Transcaucasus", in RFE/RL Research Report, vol. 2 no. 25, 18 June 1993.

${ }^{209}$ See Dimitry Trenin and Vadim Makarenko, ”What Can the Army Do When There Is Fighting All Around”, in New Times International, no. 24, 1992, pp. 8-9.

${ }^{210}$ See Thomas Goltz, Azerbaijan Diary, op. cit. [134], p. 124.
} 
with the Armenians, that seems intelligible. But why a massacre? It does not make any sense to assume that soldiers of different ethnic origins, only some of which were Armenian, would suddenly start massacring fleeing civilians. One answer to the question, suggested by Goltz, is that other forces also had an interest in making 'Khojaly a point of no return in the escalation of hatred between the two peoples'. This was very much the effect of the massacre; whereas Azerbaijani public opinion was not mobilized to a full extent before the massacre, it immediately became mobilized in the aftermath. The 'evidence for this interpretation is thin but tantalizing', as Goltz puts it. Two days after the event, Azerbaijan acquired a Russian military helicopter to fly in journalists to report the event. This helicopter was fired upon by another military helicopter, although neither the Armenians nor Azerbaijan possessed any such crafts at the time. The only plausible explanation for this is that Russian units needed to conceal their activities on the ground an therefore needed to chase away the incoming helicopter. ${ }^{211}$

In another event, six Russian special forces soldiers (Spetsnaz) were apprehended by Azerbaijani forces in Karabakh in September 1992. Several interesting factors were revealed: Most importantly, the men were not listed as deserters in the $7^{\text {th }}$ army's headquarters in Yerevan despite the fact that they admitted having been 'free-lancing' for close to a year. Moreover, they identified a colonel of the $366^{\text {th }}$ regiment as having made regular trips to the headquarters of the $7^{\text {th }}$ army in Yerevan to recruit 'volunteers' from among the Spetsnaz forces there. Meanwhile, there is equally ample evidence that 'rogue' units of the $4^{\text {th }}$ Russian army in Ganje were performing similar activities on the Azerbaijani side. Several similar cases were reported during the war; in August 1993, 40 tanks driven by Russian servicemen took part in an Armenian offensive; Russia's ambassador to Azerbaijan acknowledged this fact but insisted the Russian government bore no responsibility. ${ }^{212}$

Russian intervention is also strongly present in the political tide that brought the downfall of President Elçibey in June 1993. In fact the main character in the flow events was Surat Huseinov, the warlord that had commanded some of Azerbaijan's major offensives, such as the Mardakert offensive in Summer 1992. Huseinov had from his base in Ganje consistently cultivated relations with the $104^{\text {th }}$ airborne division, whose barracks neighbored those of his own forces. His advances on the Karabakh front were hence only partly the result of his then-reputed tactical skills and well-trained troops; in fact it had more to do with Russian materiel and Russian soldiers 'on loan'. Huseinov's fame was nevertheless to fall as quickly as it had risen. After Elçibey’s government refused to accede to the CIS, a series of events unfolded. Besides Karabakh, two other minorities became more vocal: the Lezgin organization Sadval increased its operations, and in the South of Azerbaijan a Talysh-Mugam republic was declared in early Summer. As regards the $104^{\text {th }}$ division, its help was suddenly less forthcoming. So was Huseinov's war effort. In a disastrous move, he suddenly withdrew his forces from Mardakert in February 1993, opening the way for the Armenians to take back that region and subsequently initiate the offensive on Kelbajar. While Huseinov pulled back to his headquarters in Ganje, he was discharged from the army, but kept his private army which had never been under the institutional control of what was only in name the Azerbaijani national army. In May, the $104^{\text {th }}$ division was ordered to withdraw from Ganje, an

\footnotetext{
${ }^{211}$ See Thomas Goltz, ”Eurasia Letter: The Hidden Russian Hand”, in Foreign Policy, Fall 1993, p. 100.

${ }^{212}$ Moscow News, 17 September 1993.
} 
entire year ahead of schedule; it left behind much of its weapons to Huseinov's forces. ${ }^{213}$ When in June troops loyal to Elçibey's government tried to take control over Ganje, in order to prevent Huseinov from taking over the weaponry left behind by the $104^{\text {th }}$ division, this backfired into a march on Baku by the rebellious forces under Huseinov's command. It is obvious in retrospect that Moscow had been behind Elçibey's downfall. Huseinov's withdrawal from the front after Azerbaijan's refusal to enter the CIS and the removal of the $104^{\text {th }}$ division leaving behind large amounts of weaponry not to Azerbaijani authorities but to the warlord Huseinov speak a distinct language. Azerbaijan, just like Georgia, needed to brought back into the fold.

As the army did not put up resistance, Elçibey, who seemed to have learnt from Gamsakhurdia's fate, resigned. However, before resigning, Elçibey made one move: he called on Heydar Aliyev to come back to Baku and after negotiations offered him the post of parliamentary speaker, while trying to work out a power-sharing arrangement with him. As Elçibey left Baku, he had managed to prevent Huseinov from coming to power in Azerbaijan: it is widely believed that Huseinov wanted power for himself, and if not he would have supported the return of Mutalibov rather than Aliyev. ${ }^{214}$ Aliyev then moved to appoint Huseinov Prime Minister, with a portfolio increased to cover the ministries of defense and security. As Goltz, notes, Russia immediately responded: literally within an hour of the appointment, Sadval was prohibited by Moscow, and the Talysh-Mugam republic dissolved. The symbolic was clear. However, Aliyev had not yet committed Azerbaijan to the CIS. Just as the Armenians were about to seize Jebrail on 20 August, a Russian deputy minister of foreign affairs flew to Baku with the simple reason to 'ascertain Azerbaijan's position regarding the CIS'. The Armenian offensive continued unabated, and on 5 September Aliyev flew to Moscow, and promised Azerbaijan's application to CIS membership. He even spoke of Russian military bases in Azerbaijan, financed by the Azerbaijani government; ${ }^{215}$ On 20 September, the Azerbaijani parliament ratified the accession of Azerbaijan to the CIS. In November, Kozyrev threatened the Karabakh Armenians with retaliation if they did not stop their activities; Russia also sent 200 military 'advisors' to aid the Azerbaijani army. Branding tanks and helicopters it had not possessed previously, the Azerbaijani side then went on the offensive in late 1993, as discussed earlier. ${ }^{216}$ Russia's policy and actions could not be clearer.

Nevertheless, Russia's victory was far from complete. Although Heydar Aliyev brought Azerbaijan into the CIS, he developed into as staunch a defender of Azerbaijan's independence as Elçibey had been. Despite his promises, he refused to allow Russian military on his soil-the $104^{\text {th }}$ division's withdrawal hence became permanent, although can hardly be thought to have been the original intention form the Russian side. Aliyev also continued a diversified foreign policy, and refused both to let Russia monopolize mediation in Karabakh and to allow a Russiandominated peace-keeping force. Although Aliyev initially may have seemed to move away from Turkey, this proved to be only temporary and tactical; and in any case, Aliyev's balanced foreign policy necessitated increased attention to other states, not only Russia but also Iran, Arab countries, and the West. Nevertheless, this meant that Moscow soon understood that its victory

\footnotetext{
${ }^{213}$ Elizabeth Fuller, ”Azerbaijan’s June Revolution”, in RFE/RL Research Report, vol. 2 no. 32, 13 August 1993, p. 26.

${ }^{214}$ Ibid., p. 27.

${ }^{215}$ Hill and Jewett, "Back in the USSR", op. cit. [205], p. 14.

${ }^{216}$ Hill and Jewett, "Back in the USSR", op. cit. [205], pp. 15-16, quoting The Boston Globe, 22 and 23 November 1993.
} 
had indeed been short-lived. As Moscow grew increasingly impatient with the Aliyev regime, the Azerbaijan state oil company (SOCAR) was re-negotiating the deal with a consortium of mainly western oil companies. In spite of Russian official condemnation of the deal (see next section), the group reached a deal establishing the Azerbaijan International Oil Consortium (AIOC) that quickly earned the name 'Contract of the Century', due to its ground-breaking character and its total value of almost 48 billion dollars. ${ }^{217}$ Within 24 hours of the signing of the contract, four political opponents of President Aliyev incarcerated on charges of treason, some of which were reputed to be close to Moscow, escaped from detention. On 29 September, two high government officials (one was the deputy speaker of parliament) were murdered. Three days later, OMON forces under the command of the Javadov brothers stormed the prosecutor general's office, setting of a narrowly averted coup attempt. ${ }^{218}$ Aliyev managed to avert a coup through astute manipulation, dialogue with the opposition and an impeccable utilization of public support, and humiliated Huseinov publicly. Although certain sources—notably in Russia—claim that the crisis was fabricated by Aliyev, such a theory does not seem very likely. More likely is the suggestion that Moscow saw its control over Azerbaijan slipping away with the oil deal, and therefore triggered a crisis that would bring its ally to power. Direct evidence corroborating this version centers around the escape of Huseinov through the Russian installations in Kabala and from there to the Russian North Caucasus by helicopter. ${ }^{219}$ The fact that Huseinov was openly living in Moscow (much like Mutalibov and Giorgadze) until his extradition in March 1997 speaks for itself. As for Mutalibov, he was detained in Moscow in April 1996 after much pressure from Azerbaijan; however Russian authorities deemed the evidence provided by Azerbaijan's prosecutor general 'insufficient'. ${ }^{220}$ It seems plausible that Moscow is either betting on Mutalibov's return to power or keeping his extradition as a carrot for Aliyev to make further concessions to Russia. ${ }^{221}$ Russia's tacit support for coup-makers in Georgia and Azerbaijan is hence clear.

With regard to Georgia and Azerbaijan, a certain picture can be detailed: during the first half of 1993, Moscow spent roughly equal amounts of energy on subduing both Georgia and Azerbaijan. With the June rebellion in Azerbaijan and the Georgian defeat in Abkhazia, both countries entered the CIS and Moscow initially thought to have achieved its aims. But Aliyev rather quickly showed his independent policies; Shevardnadze on the other hand was rather compliant in his policy towards Russia in 1993-95. Hence Moscow now concentrated on Azerbaijan, mainly due to the oil issue; however as Azerbaijan's relations with the West increased rapidly in all fields and the country regained some stability, it soon became rather difficult to unseat Aliyev, especially after the failed attempt of 1994. Since then, attention has focused on Georgia, besides the fact that much energy and attention was consumed by Chechnia; indeed Moscow realized that destabilizing Georgia would do very much the same effect for oil transportation as destabilizing Azerbaijan itself. Again, recalling Moscow's sense of symbolism in apparent 'coincidences', the abortive rebellion of Akaki Eliava in Mingrelia in October 1998 certainly falls into this pattern as

\footnotetext{
217 See eg. Rossen Vassilev, ”Caspian Oil—The New Great Game”, in Jamestown Prism, vol. 2 no. 1, 12 January 1996.

218 See Laura Le Cornu, Azerbaijan's September Crisis: An Analysis of the Causes and Implications, RIIA Former Soviet South Briefing, no. 1, January 1995.

${ }^{219}$ Ibid., p. 3.

220 ”Moscow Holding On to Mutalibov”, Jamestown Monitor, 2 May 1996.
} 
it occurred less than two weeks before the AIOC was supposed to decide on the final route of the main export pipeline of Azerbaijani oil. With heavy pressure from Turkey, the US, Georgia and Azerbaijan to choose a western pipeline to the Mediterranean port of Ceyhan, the oil companies nevertheless resisted due to the low oil prices and the repelling cost of this pipeline. Caught between politics and economy, then, the oil companies that were deciding on the issue may have needed a little 'demonstration' of the dangers a pipeline through Georgia could face. AIOC postponed its decision until the middle of 1999, more due to a wish to monitor the development of the oil price than anything else. With regard to Azerbaijan, Moscow now seems to be biding its time; with President Aliyev having celebrated his $75^{\text {th }}$ birthday, Russia now seems to wait for the time after Heydar Aliyev's retirement. It seems to be relatively safe to presume that not too long after this retirement, Mutalibov may try to find his way to Baku.

\section{Implications for Eurasian Strategy}

The Russian leadership's foreign policy goals in the Caucasus has hence led it to resort to intervention in the internal affairs of the Caucasian states to the degree it has been deemed necessary to bring the back to Russian quasi-control. In terms of regional politics, Russian foreign policy priorities have had equally significant consequences. As mentioned above, the primary Russian aim has been to prevent the expansion of Turkish and American influence in the region. Whereas this policy has naturally put Russia on a conflictual course with both Turkey and the US, it has led to an increasingly strong alignment with the Islamic Republic of Iran. The relationship between the two countries is multi-faceted and can naturally not been reduced to geopolitics. Economic factors are important, especially Russia's conception of Iran as a market for goods it cannot sell on western markets. ${ }^{222}$

Trade in more strategic equipment has had a larger role, though. Russia has contracted to sell $\$ 1$ billion worth of weapons to Iran by the year $1999 ;{ }^{223}$ and is planning to sell another three billion worth of weaponry to the country by $2007 .{ }^{224}$ But the bulk of the relationship is made up of political issues, and can be divided as follows: Joint interests in preventing Turkish and US influence in Central Eurasia; Nuclear cooperation enabling Iran to set up nuclear power plants, heavily criticized by the US; as well as suspected Russian support and assistance in Iran's quest to develop ballistic missile technology. Iran's incentive to develop ties with Russia are relatively straightforward. US attempts to isolate Iran in world politics have paid off relatively well, and Iran faces serious problems with respect to its participation in the world economy as well as world politics. The rapprochement with Russia meant that Iran would need to relinquish a proactive role in Central Asia and the Caucasus; nevertheless the advantages of the relationship, especially breaking Iran's isolation, by far outweigh the drawbacks as far as Tehran is concerned. Likewise, for Russia, an alliance with Tehran enabled the Moscow leadership to contain Turkish influence in its 'underbelly' in a much more active way than had Iran, for example, offered its territory without preconditions for Turkish rail, road or pipeline links. Iran also shared Russia's wish to prevent the development of a resource-rich Azerbaijani republic between the two states, which could be instrumental in severely diminishing Russian as well as Iranian influence in the region.

\footnotetext{
${ }^{221}$ See Fuller, ”Russia and the Caucasus”, op. cit. [195], p. 82.

222 See Galia Golan, Russia and Iran-A Strategic Partnership, London: RIIA, 1998, p. 5.

223 ”Russian Arms Export Predictions Continue to Grow”, in Jamestown Monitor, 3 February 1997.

${ }^{224}$ See Current Digest, 25 December 1995.
} 
An interesting factor is that even in during its 'atlanticist' period, Russian foreign policy made an exception for the case of arms sales to Iran. As Freedman has out it, 'only in the case of arms sales to Iran did Russia take a position markedly different from that of the United States' ${ }^{225}$ Since the strengthening of the conservative forces in Moscow, the Russian leadership has become increasingly ignorant of US warnings and statements regarding Iran. The appointment of Yevgeni Primakov, a Middle East specialist with very good relations with the Iranian as well as Iraqi regimes, to the post of foreign minister cemented this policy.

In view of Russia's increasing difficulties of keeping Turkey and the especially the US out of its desired sphere of influence, the Russian-Iranian relationship is likely to grow stronger with time. The strength of the relationship is corroborated not only by statements by both leaderships commenting that Russian-Iranian ties are at their historical high, but by simple facts. The nuclear and missile technology relationship is an example; nevertheless other examples are present. Most worrisome perhaps, claims have been put forward that a part of the Russian arms delivered to Armenia though 1997 passed through Iran. Although both governments have refuted the claim, it is not illogical. As Russia has no border with Armenia, direct transfers would need to pass though Georgia; with Georgia's strengthening relation to Azerbaijan, Russia was indeed unlikely to be able to transport armaments worth $\$ 1$ billion without Georgian knowledge. However, Russia could conceivably ship the armament over the Caspian sea to Iran from where it would easily be transported to Armenia, given the excellent relations between Armenia and Iran.

${ }^{225}$ Freedman, ”Russia and Iran...”, op. cit. [191], p. 94. 


\section{5 \\ Turkey: Azerbaijan's Only Ally}

With the Disintegration of the Soviet Union, a Gigantic Turkic World is being formed, stretching from the Adriatic Sea to the Wall of China.

Süleyman.Demirel

Yurtta Sulh, Cihanda Sulh

Peace at Home, Peace in the World

Mustafa Kemal Atatürk

The fall of the Soviet Union was warmly welcomed by certain circles in Turkey, which quickly rediscovered that Turkey actually had 'lost cousins' in the Caucasus and Central Asia. Enthusiasm was great, and sometimes overrode knowledge and reality. A simple example is that the Chechens during the early period of their struggle the were depicted by Turkish media as a Turkic people, until Turkish reporters to their astonishment realized that most Chechens were not Turks at all, but indigenous to the Caucasus. Nevertheless Turkey has moved to establish and entertain relations primarily with the Turkic republics of the Caucasus and Central Asia. Relations with non-Turkic republics have been distinctively less intense, though growing. The great game, as it has been called, for political and economic influence in Central Asia, nevertheless confronted Turkey with the geopolitical reality that its contacts with Turkic states would be to a large extent dependent on either of three non-Turkic transit countries, none of which were à priori clear candidates to support or allow Turkish influence in the region; two of them were even susceptible to block Turkey with all means: Armenia and Iran. Georgia was initially wary, but has moved closer to Turkey in recent years. As far as the Caucasus is concerned, the Turkish position has been heavily determined by its priority to relations with its 'brother state', Azerbaijan. Partly for reasons related with Azerbaijan and its conflict with Armenia, and partly because of historic problems dating back to the last decades of the Ottoman Empire, relations with Armenia have constantly been below the freezing point. Towards Georgia, Turkey initially had an ambivalent position. To begin with, Georgia was not seen as an important partner and was neglected in Turkish policy. Ambivalence towards Georgia was strengthened by Turkish perception of Georgia as anti-Turkish, at least as regards the Meskhetians and their professed right to return to their homeland, which has long been categorically refused by Georgian authorities. Moreover Turkey faced difficulties in developing a policy towards Abkhazia, given the existence of population groups with roots in Abkhazia considerably larger than the Abkhaz population in Abkhazia itself. Meanwhile Turkey saw the direct parallel between Nagorno Karabakh and Abkhazia, and could 
not credibly pursue different policies in these conflicts. For this reason, but also because of its own Kurdish problem, Turkey consistently supported the principle of territorial integrity, including the case of Georgia and Russia in Chechnia. Turkey has been careful not to jeopardize its important economic interests in Russia; but the main factor in the Turkish attitude has been related to the PKK rebellion in South-Eastern Anatolia. As a result, Turkey has had no option but to level its criticism of Russia to just above the level of western nations. An important factor worth mention at this point is the importance of the Caucasian Diaspora in Turkey in Turkish policy-making towards the region. The Azeri, Circassian, Abkhaz, Georgian and Chechen Diaspora groups are highly organized and exert a significant influence in Turkish society, including lobbying activities in the parliament. To a certain extent, then, Turkey's policy toward the Caucasus is defined by the existence of strong Diaspora groups.

\section{Turkish Policy 1923-91}

As has been touched upon earlier, the last years of Ottoman rule included a Caucasian campaign, which culminated in Ottoman troops reaching Baku in 1918, in the very last months of the first world war. Although the Ottoman forces were forced to surrender all their gains very quickly as the central powers were rapidly losing the war, the aims of this conquest are interesting. The Young Turks, faced with the dissolution of the non-Turkic territories of the empire since the midnineteenth century, had found that the emergence of nationalism was the reason for this process. To save the empire, they believed that they needed to create a national basis of their own for the empire's survival, led by the ideas of people like Ziya Gökalp, and his motto 'Turkify, Modernize and Islamize'. ${ }^{226}$ In this new ideology, the existence of Turkic peoples in the Caucasus and Central Asia fitted the designs of some of the Young Turks perfectly. Especially after the 1917 revolution in Russia, which led to the temporary loss of Russian control over the southern tier of the Russian empire, some Young Turks saw a window of opportunity for the creation of a new empire in place of the old one. This project, of course, failed almost immediately as the conclusion of the first world war led to the empire's total dissolution with the treaty of Sèvres of 1920. However the Caucasian campaign of 1918 must be seen not only in the context of the first world war but also as a 'last thrust' to rebuild a dying empire eastwards.

The Turkish republic of Atatürk, created in 1923 after a victorious war against the occupying Greek, British, French and Italian forces, nevertheless abstained totally from rekindling this surge to the East, despite the official fact that one of the six principles of the Kemalist ideology was Turkish nationalism, which is inscribed in the Turkish constitution. Atatürk's brand of nationalism, rather unique in the European context of the inter-war era, was not an ethnically based, exclusivist and aggressive nationalism, but an inclusive civic variant whose principal function was to create a new nation within the borders of the multi-ethnic republic of Turkey. According to Atatürk's maxim 'Ne Mutlu Türküm Diyene', (Happy who calls himself a Turk) anyone living within the boundaries of the new state was invited to take part in the nationbuilding process irrespective or ethnic origin. This was made easier by the fact that the Turkish language central to this process was a new modernized language, using the Latin alphabet, and

\footnotetext{
${ }^{226}$ See Ziya Gökalp, Türkçülügün Esaslarí, or the English Translation by Robert Devereux, The Principles of Turkism, Leiden 1968.
} 
hence not a mere continuation of the Osmanli language with heavy Arabic and Persian influences, written with the Arabic alphabet.

Concomitant to the civic character of Turkish nationalism, another maxim of Atatürk's laid the grounds for the foreign policy of the Republic: 'Yurtta Sulh, Cihanda Sulh', (Peace at home, peace in the world). This doctrine in practice meant that Turkey was an inward-looking country, which did not aspire to the territory of any other nation, but which equally demanded a total respect for its own territorial integrity. This doctrine in turn meant that Turkey officially gave up all plans to expand its influence in the now Soviet Caucasus and Central Asia. Basically, Turkey 'forgot' - with the exception of a small group of scholars and emigré organizations of Caucasian or Central Asian peoples - the existence of its linguistic and ethnic cousins. This despite the emphasis of republican historiography on the Central Asian roots of Turkish civilization.

This policy was also conditioned by the international politics of the time. During Atatürk's war for the liberation of Turkey, the Ankara government's main ally was the Bolshevik government in Moscow. Both shared a number of common characteristics: fighting western occupation powers; being new, revolutionary forces that had toppled their respective ancien régime; and being internationally isolated. These factors brought the two regimes closer, despite their ideological differences. The Bolsheviks also saw a place for Turkey in their aspirations to a world revolution; nevertheless the Ankara government was very well aware of this and kept enough distance to allow it to stay clear of Soviet manipulation.

The constructive character of Kemalist-Bolshevik relations in the early 1920s nevertheless brought with it a number of factors which have shaped the post-Soviet Caucasus. Indeed, the territorial delimitation of the Transcaucasus was certainly undertaken with Turkey's interests and wishes in mind. Turkey's clear-cut guarantor status over Nakhjivan is the primary example of this; moreover the Turkish factor, as discussed in Chapter 3, was definitely a most important factor in the Soviet decision regarding Nagorno-Karabakh's appartenance to Azerbaijan. Furthermore the creation of an Autonomous republic of Ajaria could very well not have been the case had it not been for Turkish pressure.

Turkish-Soviet relations remained cordial-on the surface-until world war two (in which Turkey was neutral) although hostility under the surface was mounting as the significance of the ideological cleavage between the two regimes gained salience. The deportation of the Meskhetian Turks during the war can be seen as an example of this increasing hostility. Immediately after the war, the Soviet Union posed a distinct threat to Turkey, with open Soviet claims to control over the Turkish straits. ${ }^{227}$ This was a direct cause of Turkey's bid to join NATO, a bid which was embraced by the United States in the framework of the emerging bipolar world. As a result of Turkey's NATO membership, it was prevented from following an independent foreign policy as regarded to Soviet Union. In any case, Turkey throughout the post-war era had enough problems in its foreign relations and domestic affairs to be able to allocate any time, efforts, or resources to pursuing an active policy as regarded the Turkic peoples of the Soviet South. In fact, the rather

\footnotetext{
227 See Mehmet Tütüncü, “The Caucasus Policy of Turkey (1990-97): An Evaluation”, in Tütüncü, ed., Caucasus: War and Peace: The News World Disorder and Caucasia, Haarlem: SOTA, 1998, p. 183.
} 
diastrous experience of the 1918 campaign was another reason for this. In the words of Mustafa Aydin,

Ever since the establishment of the Turkish nation-state ... the Republican leaders, conscious of the dangers of any kind of pan-Turkish adventures such as had characterized the policies of the last days of the Ottoman empire, had been quite consistently categorical in their denial to express any interest in the so-called 'outside Turks', especially those within the Soviet Union. ${ }^{228}$

This cautious policy had led to a singular ignorance even in informed circles in Turkey of the Turkic peoples of Central Asia and the Caucasus. With the passing of time, Turks knew that there existed 'Turks' in the Soviet Union, that people with Caucasian roots: Cherkess, Abkhaz, Ajars, Chechens among other. But the ignorance went so far that most people were badly informed about these groups. Most illustrating, many Turks initially thought the Chechens and Abkhaz were Turkic peoples only to find that these hardly understood a word of Turkish. Similarly, many Turks were surprised to find out that they could not understand Kazakh, Kyrgyz, Tatar or Uzbek, although differences in language can be overcome in a matters of months even the case of the most remote Turkic languages, or 'Turkish dialects' (Türk Lehçeleri) as many Turks refer to the Turkic languages. Turkey had basically forgotten its cousins. Exceptions existed, though, and it is no coinidence that Süleyman Demirel has been a constant advocate of active Turkish policy in the region: He visited Tashkent and Baku in 1967, where he was greeted warmly by crowds that had obviously not forgotten their Turkic origin. ${ }^{229}$

When the Soviet Union started falling apart around 1990, this 'complete indifference of Turkic heritage in the Soviet Union ${ }^{230}$ became a serious liability in more than one way. Turkey's policymakers were confronted with a situation for which they was not prepared-in fact, Turkey was distinctively unprepared. In 1989, President Özal was asked by American journalists about Turkey's stance towards the Nagorno Karabakh conflict. His astonishing answer was that being Shiite Muslims, Azeris were closer to Iran than to Turkey. ${ }^{231}$ This statement is interesting in this context to describe the lack of information of leading Turkish policy-makers. However, analysts familiar with Turkish politics will also see it in another light: it vividly illustrates Özal's penchant towards religion, by implying that religious affiliation was more important than ethnic ties so close that many Azeris do not accept the view that their language is distinct in essence from Turkish. The bottom line, nevertheless, is that until very late 1991, Turkey was reluctant to abandon its Moscow-centric policy as regarded the entire Soviet Union.

\section{The Early Euphoria}

When everything in Moscow came tumbling down, the Turkish policy underwent one of the most spectacular changes in the country's foreign policy history in a very short time. This development must be seen in the light of Turkey's geopolitical situation in 1991. With the Cold War over, the West and in particular the United States seem to have signaled that Turkey was no longer the

\footnotetext{
${ }^{228}$ See Mustafa Aydin, “Turkey and Central Asia: Challenges of Change”, in Central Asian Survey, vol. 15 no. 2, Summer 1996, p. 160.

${ }^{229}$ See Kemal Karpat, “Turkish-Soviet Relations”, in Karpat, ed., Turkey’s Foreign Policy in Transition, 19501974, London: Brill, 1975.

230 Tütüncü, “The Caucasus Policy of Turkey”, op. cit. [227], p. 183.

${ }^{231}$ Cumhuriyet, 19 January 1990.
} 
strategically important country it had been as responsible for NATO's southern flank. The reasons for Turkey's involvement can be divided into external and internal dynamics, as has been done by Baskin Oran. ${ }^{232}$ According to Oran, the primary external factor was the US, which 'pushed Turkey towards these new countries' due to its fear of Iranian influence spreading in the region. Further, the demands on Turkey by the Turkic states themselves were unexpected and Turkey had difficulties adjusting to its new role; in fact while searching for its role Turkey 'misinterpreted the great change of the 1990s ... it thought that Russia had disappeared [and] entered Transcaucasia like entering an empty space'. ${ }^{233}$ The consequences of this approach nevertheless gave way to a healthy and substantial reevaluation of Turkish policies. Finally, influence in the new states of Eurasia was a way for Turkey to regain the strategic importance for the West it had had during the cold war. The internal dynamics, on the other hand, had economical, political and psychological elements. Economically, the new states of Eurasia presented a new market for Turkish exports, as well as new sources of energy that Turkey could help developing and bringing to markets. Politically, after the 1987 rejection of Turkey by the European Community, a possible new role as a leader of the Turkic community of states would significantly increase Turkey's international standing, as well as undoing its feeling of isolation. Internally, the extreme-right political movement, with a regular support of just under $10 \%$ has been very active both in Turkey, pressuring the government to pursue a more active policy, and in the new republics, especially in Azerbaijan - with sometimes very dangerous consequences, as will be discussed below. Moreover, the Caucasian Diaspora populations which makes up some eight million people or 10$15 \%$ of Turkey's population have had a substantial influence on state policy. Finally, the psychological element of the time was the feeling of isolation which had trapped Turkey with the end of the cold war. The discovery of a possible new community of friendly nations with which Turkey had ties of kinship was a strong factor both at the popular level and in the elite, with obvious consequences for the formulation of policy.

With the emergence of the Soviet Turkic world, Turkey now could capitalize on its natural influence in this region to increase its strategic importance for the west, tightly connected as it was perceived to Turkey's eventual membership in the European Union. In the second half of 1991, the leaders of the Central Asian republics, most of which had declared their independence after the failed August coup in Moscow, made their pilgrimage to Ankara—or so it must have seemed to many Turkish politicians, who in return gave them promises of support and assistance. Turkish policy-makers in retrospect seem to have been caught by a common euphoria, led by Prime Minister Demirel who in February 1992 declared that a 'gigantic Turkish world' was being created from the Adriatic sea to the wall of China. ${ }^{234}$ Turkish dreams of the 21st century being a 'century of the Turks' were entertained also by Kazakhstan's President Nazarbayev. ${ }^{235}$ Indeed, Turks were not the only ones to be euphoric: to a certain degree, the Central Asians echoed panTurkic sentiments; Kyrgyzstan's Askar Akayev incidentally stated that Turkey was the 'morning star guiding the paths of the Turkic republics', a statement which naturally further encouraged circles in Turkey. The Central Asian were obviously at this point looking for Turkish economic

\footnotetext{
${ }^{232}$ See Baskin Oran, "The Turkish Approach to Transcaucasia and Central Asia”, in Ole Høyris and Sefa Martin Yürükel, eds., Contrasts and Solutions in the Caucasus, Aarhus: Aarhus University Press, 1998, pp. 462-463.

${ }^{233}$ Ibid., p. 462.

${ }^{234}$ See Cumhuriyet, 24 February 1992.
} 
and political assistance, and went to great lengths to charm their hosts. However, Turkey's euphoria soon tended to take a role of 'big brother' - a role that Central Asian states were significantly less ready to espouse; nevertheless Islam Karimov, president of Uzbekistan, stated that he looked on Turkey as an 'agabey', that is, big brother. Despite Turkish assurances that any further cooperation would be on an 'equal basis', the general attitude of certain Turkish policymakers hinted otherwise. For example, still in late 1993 ambassador Umut Arik, the head of TIKA, ${ }^{236}$ told students of Ankara's Middle East Technical University en passant that 'the languages of the Central Asian peoples are not sufficient to be state languages; they must be replaced with Istanbul Turkish'. ${ }^{237}$ The reactions of Central Asian students present at the occasion can easily be imagined.

Although the examples of Turkey's attitudes are taken from the Central Asian context, it points out the early confusion and euphoria of Turkey's policies, policies that applied to the Caucasus equally. The nearby Caucasus presented a situation was distinctively more complex than in more far-away Central Asia. The consistently most important country of the entire Caucasus and Central Asia was from the beginning Azerbaijan, although many observers argue that 'the keystone to Turkish policy is Armenia', due to its ability to obstruct Turkey's political and economic influence and sustain Russian influence in the region. ${ }^{238}$ Turkey was the first state to recognize Azerbaijan, several weeks before it recognized the other states of the region. Azerbaijan was crucial for Turkey in more than one way. Naturally, any substantial Turkish influence in Central Asia depended on influence in the Caucasus; and in the Caucasus, Azerbaijan was defined as the strategically most important country not only by Turkey, but by Iran and later the United States as well. For Turkey especially, Azerbaijan was a logical strategic pillar for influence in the wider region because of the close ethnic affinity, all but lack of linguistic difficulties, potential petroleum wealth, and its strategic location as the only Caucasian state on the Caspian Sea. Süha Bölükbasi has outlined Turkey's foreign policy priorities in Azerbaijan as follows:

1) Support for Azerbaijan's independence;

2) Support for Azerbaijan’s sovereignty over Nagorno Karabakh;

3) A desire to prevent or limit a Russian comeback to Transcaucasia;

4) Participation in the Azerbaijani oil production, and export of significant amounts of this oil through Turkey;

5) Preserving a friendly, though not necessarily pan-Turkist, government in Baku. ${ }^{239}$

These principles are to be seen in the context of policy toward Azerbaijan; however, as Turkey's policy in the entire Caucasus is concerned, a few more objectives can be added: in general, Turkey supports the creation in the long term of a cooperative environment in the Transcaucasus as a whole (involving solutions to all conflicts in the area) without which stable

\footnotetext{
${ }^{235}$ See discussion in Aydin, "Turkey and Central Asia”, op. cit. [228], pp. 160-61.

${ }^{236}$ TIKA (Türk Isbirligi ve Kalkinma Ajansi, Turkish Cooperation and Development Agency) is the agency specializing on development cooperation with the former Soviet republics.

${ }^{237}$ Recorded by the present author on location in Ankara, 1993.

${ }^{238}$ Eg. Oran, ”The Turkish Approach”, op. cit. [232], p. 466.

${ }^{239}$ See Süha Bölükbasi, “Ankara’s Baku-Centered Transcaucasia Policy: Has it Failed?”, in The Middle East Journal, vol. 50 no. 1, Winter 1997.
} 
institutions and market economy cannot develop. In this framework, Turkey seeks a normalization of its relations with Armenia; nevertheless only under certain conditions, that will be discussed in detail below. Turkey furthermore seeks to promote its economic influence in the Transcaucasus, and through the Transcaucasus to Central Asia. Turkey is therefore a wholehearted supporter of the TRACECA project. In the absence of a rapprochement with Armenia, Turkey is capitalizing increasingly on relations with Georgia on every level, deemed crucial as the only road and rail connection to Azerbaijan. The discussion below will seek to investigate whether Turkey has been successful in fulfilling its objectives, and how they have developed during the time that has elapsed since the collapse of the Soviet Union.

\section{Turkey: Azerbaijan's only Ally?}

As has been seen in Chapter 3, Azerbaijan for a number of reasons remained internationally isolated during the whole conflict over Nagorno Karabakh. Russia, Iran, and the United States (initially) all pursued policies in the conflict inclined towards Armenia. The only country that has constantly expressed its support for Azerbaijan is Turkey. In all international fora Turkey tried to explain and promote the Azerbaijani interpretation of the conflict, and Turkey was certainly instrumental in preventing a pro-Armenian approach from totally dominating these fora and world media. Furthermore Turkey and Azerbaijan since 1992 jointly held an embargo on Armenia, and Turkey refuses to normalize its relations with Armenia as long as the latter occupies territories in Azerbaijan. However, despite its support for the Azeri cause, Turkey has largely stopped short of furnishing Azerbaijan with weapons or affluent financial aid which would enable it to buy any; Turkey furthermore never threatened to intervene militarily on Azerbaijan’s side.

Since the break-up of the Soviet Union, Turkey from the start gave priority to Azerbaijan in its relations with the republics of the former Soviet Union. Thus Ankara recognized Baku on November 9, 1991, almost a month before it granted recognition to the other former republics. ${ }^{240}$ In the first half of 1992, however, the internal turmoil in Azerbaijan and the political instability of the country led to a difficulty in improving and developing relations. $^{241}$ Ayaz Mutalibov, a Soviet technocrat with little legitimacy was not, from Turkey's perspective, the best person with which to initiate a lasting and constructive relationship.

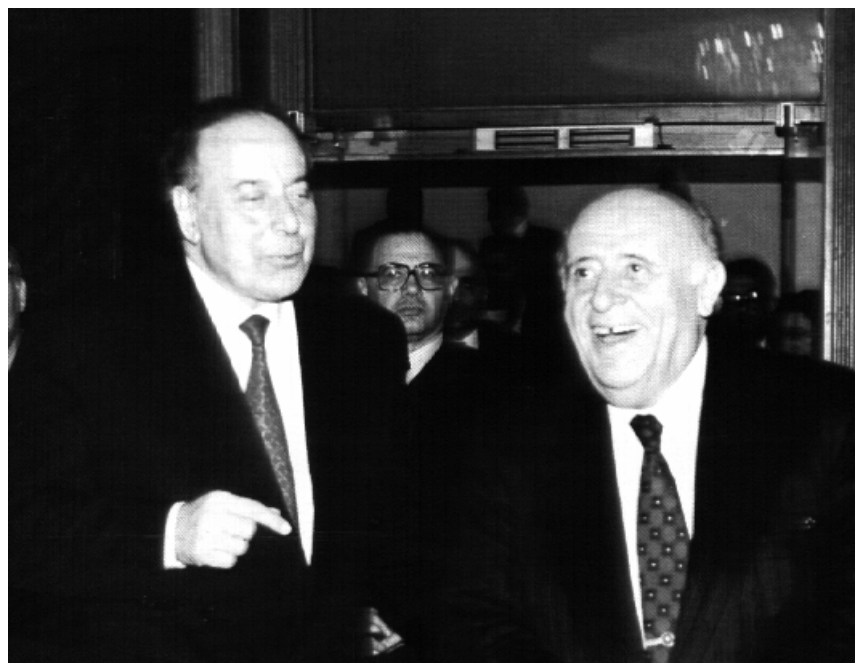

Figure Error! Unknown switch argument.: Heydar Aliyev and Süleyman Demirel

${ }^{240}$ See FBIS-WEU, 12 November 1991, quoting TRT Television, 9 November 1992.

241 In February 1992, ex-communist President Ayaz Mutalibov was ousted by a popular revolt led by the Azerbaijan Popular Front (APF). In his place, the parliamentary chairman Yaqub Mamedov was installed as acting president. In May Mutalibov attempted to regain his position, but again the APF opposed him and forced him to flee the country. Until 7 June 1992 Isa Gamber served as acting president until Abülfez Elçibey was elected President by popular vote in a multi-candidate election. 
Nevertheless even after Elçibey came to power, Turkey did not commit the mistake of tying its relations to one person, which otherwise could have been the case. Elçibey's fancy for the Turkish Model for Azerbaijan, his militant secularism and his very anti-Iranian views may certainly have spelled out what many Turks thought privately; Elçibey's political views were in fact more than Turkey could ever had hoped for. The problem lied not in Elçibey's views, but in his increasingly erratic behavior and his statements which antagonized both of Azerbaijan's mighty neighbours, Russia and Iran. Elçibey was not and is still not a man with a sense of diplomatic finesse and does not claim to be; sometimes he might even have been a bit too pan-Turkic for Ankara's taste. For example, Elçibey had reportedly even been ready to accept a federation with Turkey, and often spoke of the reunification of North and South Azerbaijan. Elçibey was certainly seen by certain circles in Turkey as a potentially destabilizing factor, not fit to govern, and counterproductive to Turkey's objectives.

When the Elçibey government was ousted in June 1993 by the coup which, although orchestrated by colonel Surat Husseinov, brought Heydar Aliyev to power, this development was seen as a loss for Turkey and a gain for Russia, as it was in a way a repetition of a phenomenon which had occurred in other former Soviet republics such as Georgia and Lithuania, that is a former Soviet leader returning to power. Indeed, voices both in Turkey and in the west saw in the power shift Turkey's inability to keep a friendly regime in power and to keep its position in Azerbaijan. In Turkey itself, voices were heard that Elçibey's fall would mean an end to the Turkish model. ${ }^{242}$ In any case, Russia's ability to interfere in the internal affairs of the Caucasian states was reaffirmed, as evidence of Moscow's backing Husseinov were blatant. ${ }^{243}$ Seeing the replacement of Elçibey with Aliyev as a victory for Moscow would nevertheless be a serious mistake, as explained in chapter 3. For although Aliyev made some accommodating moves towards Moscow, by joining the CIS for example, he staunchly refused to accept the stationing of Russian troops in Azerbaijan. The fact that Aliyev did not turn out to be the Moscow-friendly leader the Russians had hoped for is best illustrated by the fact that the Russians actively tried to remove him after little more than a year; lingering allegations of Russian involvement in Husseinov's coup attempt in October 1994 have been put forward by Baku. With respect to Turkey, it is clear that unlike Elçibey, who gave priority to Turkey, Aliyev plays the Turkish card whenever it suits his purposes, but can turn his back to Ankara as well if necessary. In September 1993, he annulled many agreements signed between the Elçibey administration and Turkey, ordered Turkish nationals to seek Visas before entering Azerbaijan, and dismissed 1'600 Turkish military experts serving in the country. ${ }^{244}$ Only a year later, Aliyev courted Ankara and expressed his confidence in the brotherhood existing between the two countries. Furthermore Aliyev attempted to broaden Azerbaijan's links with the Muslim world and courted Iran and Saudi Arabia, selectively, even attempting to ameliorate his Islamic credentials. ${ }^{245}$ Thus, clearly, for Turkey the replacement of Elçibey with Aliyev meant a less reliable and more unpredictable

\footnotetext{
${ }^{242}$ See Gün Kut, “Elçibey’in sonu, Türkiye modelinin sonudur”, in Cumhuriyet, 24 June 1993.

243 See Goltz, ”Eurasia Letter”, op. cit. [211].

244 See Foreign Broadcast Information Service, Central Eurasia Series, (Hereafter FBIS-CEA) 8 September 1993, quoting Aydinlik, 5 September 1993.

${ }^{245}$ For a discussion of the issue, see Joseph A. Kechichian, and Theodore W. Karasik, "The Crisis in Azerbaijan: How Clans Influence the Politics of an Emerging Republic”, in Middle East Policy, Summer 1996, pp. 64-65.
} 
regime in Baku. Nevertheless much of Aliyev's policy toward Turkey was intended to prove the point that it is not only Azerbaijan that needs Turkey; Turkey also needs Azerbaijan. From a relative position of force, then, Aliyev could address the Turkish parliament on 6 May 1997 and state that 'we are one nation but two states' (Bir millet, Iki Dövlet)

\section{Nagorno Karabakh: Turkey's Wake-Up Call}

In examining Turkish policy in the Nagorno Karabakh conflict, it should first be mentioned that Azerbaijan never officially asked for a Turkish intervention in the conflict. According to Azerbaijan's ambassador in Ankara, Mehmet Novruzoglu Aliyev, the main support Azerbaijan wanted from Turkey was to try to use its Western alliance contacts to show Azerbaijan's side of the story to the world. ${ }^{246}$

In the framework of bilateral relations, Turkey concluded a number of economic and commercial agreements with Azerbaijan, started to beam Turkish state television channels into Azerbaijan, followed by private channels and Turkish newspapers. ${ }^{247}$ Further Turkey has offered assistance in Azerbaijan's transition to the Latin alphabet by sending books and typewriters to Azerbaijan. However, in the end, Turkey's image in Azerbaijan largely depended upon its policy and actions with respect to Karabakh. Initially, Turkey embarked on a policy of neutrality, which simultaneously enabled it to present itself as an impartial mediator between the parties. Although Armenia was wary of Turkish involvement from the beginning, it did not immediately denounce Ankara's efforts. Hence Turkish diplomats, especially then foreign minister Hikmet Çetin, embarked on several rounds of shuttle diplomacy to the region and European capitals, ${ }^{248}$ and were instrumental in bringing the issue to the agenda of the OSCE. ${ }^{249}$ Furthermore, Çetin upon Azerbaijani request used his connections in the West to try to bring the conflict to the attention of western governments, notably by personally telephoning US secretary of state James Baker on the issue. ${ }^{250}$ Prime Minister Demirel defended his cautious policy by arguing that there was no legal basis for a Turkish intervention, and that in any case the Azeris had not asked for it. ${ }^{251}$

However, the Turkish attempt at neutral mediation was not destined to last long, as statements by President Turgut Özal in particular would compromise Turkey in Armenia's eyes. After the massacre on Azeri civilians in the Karabakh town of Khojaly in late February 1992, large antiArmenian demonstrations were held in Turkey, with tens of thousands of people demonstrating in favour of an intervention on Azerbaijan's behalf. The Turkish government could not disregard these demands from the public, especially as most politicians shared the feelings of solidarity with Azerbaijan that the Turkish people was displaying. In particular, Özal on several occasions stated

\footnotetext{
246 Interview with Dr. Mehmet Novruzoglu Aliyev, Ambassador of the Republic of Azerbaijan in Turkey, Ankara, December 1996.

${ }^{247}$ See FBIS-WEU, 3 March 1992, quoting Milliyet, same date.

${ }^{248}$ See FBIS-WEU, 9 March 1992, quoting Türkiye Radiyolarï, 6 March 1992.

${ }^{249}$ See Le Monde, 27 February 1992, p. 7; See also FBIS-WEU, 9 March 1992, quoting TRT Television, 7 March 1992. On the CSCE's view of Turkey's role, see FBIS-WEU, 11 March 1992, quoting TRT Television, 10 March 1992.

${ }^{250}$ See FBIS-WEU, 9 March 1992, quoting Türkiye Radiyolarï, 8 March 1992.

${ }^{251}$ See FBIS-WEU, 10 March 1992, quoting TRT Television, 9 March 1992.
} 
that the Armenians should be 'frightened a little', ${ }^{252}$ statements which sent shock waves through Armenians in Armenia and in the Diaspora, and enabled the latter especially to pursue a policy of discrediting Turkey as planning a 'new' genocide on Armenians. In any case, Turkey soon adopted a more pro-Azerbaijani stance, as Armenian military advances on Azerbaijani territory intensified.

To a certain degree, domestic pressures made it impossible for Turkey to keep a neutral stance in the conflict. Public opinion, first of all, was strongly pro-Azeri, outraged over the Armenian military advances in Karabakh and Azerbaijan proper, and especially infuriated by pictures of the fleeing Azeri refugees. The Turkish press was filled with criticism of the government's mild stance on the Armenian advances, and generally of the feeble performance of Turkey in the Caucasus and Central Asia compared to its aims of becoming a regional leader. ${ }^{253}$

The opposition did not miss this opportunity to criticize the government, either. Criticism for standing idle while the Azeri brethren were being massacred came from virtually all political directions. The most natural critic was the leader of the Nationalist Labour Party (MHP) Alparslan Türkes, who at a very early date, in late February, argued for a Turkish military intervention in the war, arguing that 'Turkey can not stand idly by while Azerbaijan's territory is being occupied'. ${ }^{254}$ Former Prime Minister and leader of the Democratic Left Party, Bülent Eçevit, argued that Turkey's failure to demonstrate unambiguous support for Azerbaijan might undermine Turkey's prestige in Azerbaijan and Central Asia. ${ }^{255}$ However the perhaps mightiest challenge to the government came from main opposition leader and head of the Motherland party, Mesut Yilmaz. On 4 March already, he argued for troops to be deployed along the Armenian border and reminded the public that Turkey retains a guarantor status over Nagorno Karabakh, ${ }^{256}$ a statement which nevertheless remains questionable as to its correctness. On several later occasions, Yilmaz reiterated his belief that Turkey should deploy troops near the Armenian border and Nakhjivan to show the seriousness of its opposition to Armenia's behaviour. ${ }^{257}$ The government naturally could not stay without being influenced by this compact pressure.

Indeed, already in the beginning of March, Turkey announced that it would inspect airplanes headed for Armenia passing over Turkish airspace, in its effort to implement an arms embargo on the warring parties. ${ }^{258}$ Furthermore Turkey helped enforcing Azerbaijan's economic embargo on Armenia, refusing to allow aid for that country to pass through Turkey. By the middle of March, Demirel started altering his stance. In an interview with the Washington Post, Demirel stated that he was under severe pressure to take more decisive action, and did not rule out a Turkish military intervention. $^{259}$

\footnotetext{
252 See FBIS-WEU, 5 March 1992, quoting news agency Anatolia, same date.

253 See, for example, the religious-conservative dailies Türkiye and Zaman. For an English sample article, see FBIS-WEU, 5 March 1992, quoting Türkiye, 1 March 1992.

${ }^{254}$ See FBIS-WEU, 27 February 1992, quoting Anatolia News Agency, 25 February 1992.

255 See Fuller, Elizabeth, “Nagorno Karabakh: Can Turkey Remain Neutral?”, in Radio Free Europe/Radio Liberty Research Report, v. 1 no. 14, 3 April 1992, p. 37, quoting Handelsblatt, 11 March 1992.

${ }^{256}$ See FBIS-WEU, 5 March 1992, quoting Anatolia News Agency, 4 March 1992.

${ }^{257}$ See FBIS-WEU, 13 March 1992, quoting Turkiye Radyolarï, 12 March 1992.

${ }^{258}$ See FBIS-WEU, 3 March 1992, quoting TRT Television, 2 March 1992.

${ }^{259}$ See Fuller, op. cit, [22], p. 38, and The Washington Post, 19 March 1992.
} 


\section{Turkey's Dilemma in the Karabakh Conflict: The Constraining Factors upon Turkey}

Despite the increasingly pro-Azerbaijani stance of Turkish politicians and the open demands for intervention, Turkey did not supply Azerbaijan with anything that could have helped it turn the tide of the war. Some Turkish retired army officers were encouraged to train the Azerbaijani army, and did so; Armenians claim that Turkey provided weapons, but in case such shipments took place, these weapons were insignificant considering what Turkey could have provided had it wanted to or been able to. Turkey's policy in the Nagorno-Karabakh conflict shows clear restraint on the part of the policy-makers in supporting Azerbaijan to the degree most of them certainly wished to do. In fact, it is possible to discern at least five factors that constrained Ankara in the formulation and implementation of its policy towards Armenia and Azerbaijan.

- A first factor, in the domains of the principles of Turkish foreign policy, is the doctrine of Kemalism, which prohibits any kind of adventurism abroad. In the original interpretation of the above.noted maxim Yurtta Sulh, Cihanda Sulh, Turkish policy-makers refrain from involving the country in any adventures abroad. There are two possible exceptions to this doctrine: The Turks on Cyprus, and perhaps the Mosul area of Northern Iraq, areas which were both considered at the time of Atatürk to be morally if not actually belonging to Turkey. In the case of Azerbaijan, this being an independent and sovereign country, Turkey should hence not involve itself in the conflict this country faces with another independent state. In practice, Turkish decision-makers naturally realized that involvement in the Nagorno-Karabakh conflict could lead to a further destabilization of the Caucasus, something which was definitely not in Turkey's interests. Furthermore it is doubtful whether the powerful military would have followed orders of direct intervention; in the Gulf war, chief of staff Torumtay refused to agree with president Özal's participation in military involvement against Iraq, and resigned as a result of his orthodox following of Kemalism.

As a response to such prudence, opposition politicians - in particular the nationalists under the late Alparslan Türkes, have argued that Azerbaijan represents as an important region for Turkey as Cyprus does. Nevertheless the regime seems to have adhered to the original interpretation of the doctrine. Furthermore it can be argued that Turkey's (by now regular) incursions in Northern Iraq can not be compatible with the doctrine, and that consequently Turkey could at least make some military moves such as troop deployments in Armenia's vicinity or in Nakhjivan; As Mesut Yilmaz correctly commented, Turkey can move its troops freely on its own territory and is responsible to no one in doing so. ${ }^{260}$ Turkey's military maneuvers in October 1998 which brought the country to the brink of war with Syria are one example; in fact Syria, which is a significant military power, saw the Turkish threat as strong enough to surrender its support to Kurdish PKK rebels in Turkey, expelling the PKK leader Abdullah Öcalan. Armenia, with its limited military capabilities, would certainly have been more malleable than Syria. In any case, Turkey's policies can not be solely explained by this principle.

- Secondly, the perhaps most important constraint upon Turkey was its Western alliance. As Western countries wanted to stay out of the conflict, while in some cases tacitly or openly supporting Armenia, they exerted pressure on Turkey not to involve itself on Azerbaijan's side. Furthermore it was generally believed that Turkish involvement would increase the risk of an escalation of the conflict, in the worst case leading to a confrontation between Turkey and Russia, possibly involving Iran as well. NATO was one of the organizations where Turkey was subjected

${ }^{260}$ See FBIS-WEU, 5 March 1992, quoting Anatolia News Agency, 4 March 1992. 
to western pressure, with the argument that Turkey's NATO membership does not permit it to pursue an 'adventurist' policy in its 'near abroad', to use an otherwise Russian term. In a wider context, Turkey's relations with and will to integrate into Western Europe gives western powers a certain amount of influence over Turkey. By using a mixture of carrots and sticks, the western leaders ensured that Turkey did not diverge markedly from the official western policy towards the conflict. Two factors in particular ensured Turkey's compliance with the West.

- The first factor is Turkey's reliance upon US military aid for its war against the Kurdish separatist organization PKK (Kurdish Workers Party) in South-East Anatolia. ${ }^{261}$ In fact, given America's partiality at that time for Armenia in the conflict, Turkey feared that in case it supported Azerbaijan to a greater extent the United States would retaliate by cutting US military aid to Turkey - indeed the pro-Armenian Congress would certainly have pushed through such a decision. The fact that the United States in the past has used this weapon to make Turkey comply with international Human Rights standards ensure that such a threat would be seen as real in Ankara. In the extreme case of a direct Turkish military involvement, Turkey would have to take into account the possibility of an arms embargo against itself. The importance of this factor is illustrated by the observation of many analysts that one of the reasons for the closer TurkishIsraeli cooperation in later years has been an attempt to diversify Turkey's sources of armament at a time when Germany, in particular, but other western powers as well, are increasingly reluctant to contribute to Turkey's crushing of its Kurdish rebellion. ${ }^{262}$ The decision of the US congress to suspend $10 \%$ of US military aid to Turkey in July 1994 should be seen in this context as well. ${ }^{263}$. The number of military deals between Turkey and Israel testify to this.

- The second factor is Turkey's quest for full membership in the European Union (EU). Indeed, the relations between Turkey and the EU have been strained in the 1990s by Turkey's failure, in the eyes of the Europeans, to speed up its democratization process and to improve its Human Rights record. In this context, keeping in mind that Turkey has been negotiating for a customs union with the EU, it is clear that any Turkish adventurism in the Caucasus would not serve its interests on the 'western front'. On the other hand, a balanced Turkish policy in the whole region, involving a normalization of relations with Armenia, could serve Turkey's purposes by highlighting Turkey's importance as a stabilizing factor in the region and a bridge between the Caucasus and Europe. Moreover, in the event that Azeri oil would flow to the Turkish Mediterranean port of Ceyhan, as proposed by Turkey and Azerbaijan, ${ }^{264}$ this would increase

\footnotetext{
${ }^{261}$ For a discussion on Turkish-US relations, involving the Kurdish and aid issues, see Mahmut Bali Aykan, “Turkish Perspectives on Turkish-US Relations Concerning Persian Gulf Security in the Post-Cold War Era”, in The Middle East Journal, Summer 1996.

${ }^{262}$ Ibid., quoting Die Zeit, 8 April 1994.

${ }^{263}$ See Aykan, op. cit. [261], p. 351.

${ }^{264}$ On 9 March 1993 Turkey and Azerbaijan signed an agreement for the construction of a 1060-km pipeline which was planned to go from Baku into Iran, then back into Nakhjivan and from there cross over into Turkey. (See BBC Summary of World Broadcasts, (Middle East), 16 March 1993) However Azerbaijan's political instability and its difficult relations with Russia make the pipeline project unclear. Furthermore the deal was signed without consultations with Iran, although the drawing of the pipeline would include Iranian territory. Iran, for itself prefers the drawing of a pipeline from Baku through Iran to the Persian Gulf, thus staying within Iran. Hence other drawings of the Baku-Ceyhan pipeline have been discussed, and to day's date a drawing over Georgian territory seems to be the most realistic alternative, although it would mean $1650 \mathrm{~km}$ instead of 1060 . Hence the Turkish ministry of energy declared that for the feasibility of such a project, a guaranteed throughput of at least 25 million tons of crude annually is necessary. For a recent assessment of the pipeline issue, see Nazlan Ertan, “Baku-Ceyhan: Pipeline or Pipe Dream”, in Turkish Probe, 17 May 1996, pp. 19-20.
} 
Turkey's economic importance for Western Europe and be instrumental in easing tensions. Perhaps the Europeans would be incited to put economic benefit before moral concerns for Turkey's democratization and Human Rights record, hence easing their pressure on Turkey. Thus there would be an opportunity for Ankara to try to restructure its relations with the West to a mutual benefit relationship where both sides are dependent on each other, rather than one where there is a one-sided relationship, as the present one where Turkey is dependent upon Europe.

- The third factor concerns Turkey's relations with the Russian Federation, and can be seen either as respect or fear for Russia's might, or as a policy which gives priority to keeping good relations with Moscow for political but also economic reasons, given Turkey's huge private business relations with Russia. ${ }^{265}$ Indeed, the large emerging Russian market has been penetrated by Turkish firms, especially in the construction field. The total volume of trade between the two countries ranged at between US\$ three to four billion; in 1992 Turkey's trade with Russia was five times larger than its trade with Azerbaijan and the Central Asian states combined. ${ }^{266}$ Hence Turkey needs to keep its relations with Russia at a somewhat decent level for its own interests, given the fact that the hard-currency earned by Turkish companies in Russia is increasingly important for the Turkish economy. Also, Turkey seems interested in purchasing arms from Russia for its war in its South-East, at least to broaden its sources of weaponry as mentioned above. Furthermore, at every occasion that Turkey has signaled its intention to involve itself in Karabakh, Moscow has responded promptly and without trying to conceal its discontent with Ankara's policies. An illustrating example occurred in April 1993, immediately after Armenian forces had seized the Kelbajar region of Azerbaijan and established a second land corridor between Nagorno Karabakh and Armenia. As President Özal accused Russia of supporting the Karabakh Armenians, he announced that Turkey would intensify its military relations with Azerbaijan and send arms to that country. ${ }^{267}$ As a response, Russian Defense minister Pavel Grachev during a visit to Ankara reportedly warned Ankara in quite undiplomatic ways to stay out of Azerbaijan. ${ }^{268}$ Clearly, Turkey retains a certain degree of respect for Russia; in fact the Turkish Chief of Staff, General Dogan Güres, in June 1994 expressed his belief that 'Russia is now posing a greater threat to Turkey than it used to during the Cold War. ${ }^{269}$ In this context, Turkey has been unwilling to risk its relation with Moscow for the sake of active unilateral support for Azerbaijan in the Karabakh war. This fact also illustrates the complex web of relations, much the result of Turkey's geopolitical location, that Turkey has to take into consideration while formulating its foreign policy.

- A fourth factor which both directly and indirectly has constrained Ankara, particularly regarding its ability to put pressure on Armenia, is the legacy of the 1915 alleged genocide on Eastern Anatolia's Armenian population by the Ottoman army. Without going into the details of the events during the first world war, which have been studied lengthily by other scholars, ${ }^{270}$ suffice it

\footnotetext{
265 For a discussion of the Moscow-Ankara rivalry, see Süha Bölükbasí, “Ankara’s Baku-Centered Transcaucasia Policy”, op. cit. [239].

266 See Elizabeth Fuller, “Turkish-Russian Relations, 1992-1994”, in RFE/RL Research Report, 6 May 1994, quoting The Independent, 1 June 1993.

${ }^{267}$ See Fuller, op. cit. [266], quoting The New York Times and ITAR-TASS, 15 April 1993.

268 ibid., quoting The Independent, 1 July 1993.

${ }^{269}$ See FBIS-WEU, 6 June 1994.

${ }^{270}$ For an Armenian account of the episode, see Richard Hovannisian (ed.), The Armenian Genocide in Perspective, New Brunnswick, N.J.: Transaction Publishers, 1988. For a Turkish account, see Kamuran Gürün,
} 
here to state that since the 1970s, Armenians, particularly in the United States, have been actively lobbying for an official recognition of the Ottoman persecutions on Armenians. Ankara, on the other hand, refuses to accept the historiography of the Armenians, instead claiming that it was a general time of chaos and war, which led to high numbers of lost lives both among Armenians and Turks. In January 1991, Soviet Armenia declared that it did not recognize the existing borders between Turkey and Armenia, laid down in the Russo-Turkish treaty of 1921, thus blocking the establishment of future diplomatic relations. ${ }^{271}$ Ankara feared that any Turkish move to actively support Azerbaijan would be inflated by the powerful Armenian Diaspora in the West so that Turkey would be pictured as planning new atrocities on Armenians. This fear was only proved correct with the reaction to the above-mentioned statement by President Özal that the Armenians should be 'frightened a little'. In general, Turkey has been carrying the burden of the massacres on Armenians for decades, including having dozens of its diplomats killed by Armenian terrorists, whose actions were met by a rather indifferent attitude in the West, in many cases escaping the hard condemnations that other terrorist organizations have faced. ${ }^{272}$ Thus since Armenia's independence Turkey has made a distinct effort not to make it seem as if it had a hostile attitude to independent Armenia from the beginning. These circumstances in turn made it difficult for Turkey to be as anti-Armenian—or pro-Azeri—as it might have liked to be. In fact, statements by the opposition and public demonstrations tend to show that the government's policy towards Armenia is distinctively more lenient than what the general atmosphere in Turkey otherwise would allow. In particular, right-wing media has been successful in creating a public anger against the atrocities committed by the Karabakh Armenians on the civilian Azeri population of Karabakh. ${ }^{273}$ In trying to calm the public, Prime Minister Demirel indeed stated that a Turkish intervention on Azerbaijan's side would only result in putting the whole world behind Armenia, illustrating the point made here. ${ }^{274}$

- A last point which might have influenced Turkish behaviour, as a precedent, is the international reaction which Turkey faced after its invasion of Northern Cyprus in 1974. In fact, certain parallels can be drawn between Cyprus and Karabakh. Both cases involve Turkish/Turkic kin who have been subjected to aggression and whose position and civil rights are in danger. Furthermore Turkey according to international treaties reserves a guarantor right in Cyprus, and the treaties between Turkey and the Soviet Union stipulate the Turkey must be consulted fro an alteration of Nagorno-Karabakh's territorial affiliation. Naturally, there are huge differences between the two, especially to the extent of Turkey's guarantorship and the general constellation of power in the respective regions. However the memory of the reaction it faced in Cyprus might have helped to calm any fervor among the Turkish leadership to rush to the support of the Azeri kin.

The Armenian File: The Myth of Innocence Exposed, New York, N.Y.: St. Martin’s Press, 1985. See also Feigl, op. cit. [14].

${ }^{271}$ See Discussion in Goldenberg, op. cit., [6].

${ }^{272}$ For an account of Armenian terrorism, see Michael M. Gunter, "The Armenian Terrorist Campaign against Turkey”, in Orbis, Summer 1983, or by the same author, "Pursuing the Just Cause of Their People” : A Study of Contemporary Fel! Bokmärket är inte definierat.Fel! Bokmärket är inte definierat.Armenian Terrorism Westport, Conn.: Greenwood Press, 1986.

273 See issues of the newspapers Zaman and Türkiye, as well as a statement by the head of the Turkish state's Directorate for Religious Affairs, Mehmet Nuri Yilmaz, in FBIS-WEU, 5 March 1992, quoting Türkiye Radyolari, same date.

${ }^{274}$ For an example on Demirel's statements to explain the government's Karabakh policy, see FBIS-WEU, 10 March 1993, quoing TRT Television, 9 March 1993. 
To recapitulate, heavy pressure has been exerted on Turkey not to involve itself too deeply in Karabakh. Furthermore many Turkish interests, particularly its quest for integration into western Europe and its commercial relations with Russia has discouraged Ankara from being more active in the issue.

\section{The Azeri Reaction}

While observing the restraint in Turkey's support for Azerbaijan, particularly given the euphoric statements on 'brotherhood' and Turkish leadership in the region that were common in Ankara during 1991-92, it is interesting to see what kind of a reaction Azerbaijan had to these developments. Basically, the Azeri reaction was two-fold: First of all, a popular feeling of deceit and Turkish betrayal; and second an understanding among the leadership of the constraints upon Turkey. The primary factor that angered the Azeris was the Turkish abortive energy deal with Armenia in November 1992, discussed below. Had this deal become reality, it would have destroyed Azerbaijan's main bargaining chip at the time-its energy embargo on Armenia. Although it was soon disbanded, the deal left a permanent seal on the perception the Azeris have of Turkey. The Azeri view was expressed as "They claim to be our brothers, but give bread to our enemies". ${ }^{275}$ Whereas it might have been possible to explain to the Azeris why Turkey does not give direct support to Azerbaijan, it certainly was difficult to justify the need of cooperating with their enemy. Hence in many ways, parts of the Azeri population became disillusioned with Turkey. If they had hoped that Turkey would present itself as Azerbaijan's main protector, it soon became clear that Turkey lacked either the capacity or the will to assume such a role.

Among the Azeri leadership, however, there is more of an understanding of Turkey's difficulties. Turkey's position as a member of NATO, in particular, as well as its own turmoil in the South-East form legitimate reasons as to why Turkey had no possibility to support Azerbaijan more than it did. ${ }^{276}$ This is not to say, however, that the Azeri leadership is satisfied with Turkey's attitude. Clearly, Turkey has lost a lot of its prestige in Azeri eyes and perhaps to a certain extent its privileged position in that country. However, the Azeris are faced with the cold fact that Turkey, despite its shortcomings, is the only country it can count on as an ally against the Armenians, which should ensure the continuation of cordial relations between the two countries.

\section{The Javadov Scandal}

However, Aliyev's visit happened in the aftermath of a scandal of potentially immense proportions that was contained very narrowly. As mentioned in Chapter 3, a coup in March 1995 occurred in Baku, led by Rovshan Javadov. Although it has been widely believed that this coupas most others in the Caucasus - were directed or sponsored from Moscow, there was, as Thomas Goltz has pointed out, something in this coup which didn’t fit the general picture:

Ravshan Javadov hardly fit the profile of pro-Moscow putschist. Nor did any of the men that answered his call. Either by participation or by default, they included former ministers in the Elçibey government, Iskender Hamidov and Towfig Gasimov. Indeed, Javadov was appealing to the Popular Front to urge the people to rise and dispose of Aliyev. He also called on those Chechen fighters in

\footnotetext{
275 This statement seems to come back over and over again in conversations with Azeris.

${ }^{276}$ Interview with Dr. Novruzoglu, op. cit., [246].
} 
Baku to join in the fray. Given the personalities and politics involved, it looked less like a proRussian coup attempt than one with distinct Turkish underpinnings. ${ }^{277}$

As a matter of fact, the primary Turkish origins of the coup became clear very soon; the evidence that has come up showed that circles within the Turkish intelligence service, or MIT (Milli Istihbarat Teskilati) cooperated with certain right-wing groups and were involved in criminal activities in Azerbaijan - a direct corollary of the Susurluk scandal of police and state relations with organized crime that has been unveiled lately. ${ }^{278}$ At this point, the event was an embarassment to Turkey for not having been able to control its own intelligence personnel and its right-wing extremists. But it was still manageable. When details of the unveiled Susurluk scandal were beginning to spill out in Turkey, the Azeri affair was one of them. To the horror of the Turkish side, everything was about to spill out in the media; publicity had been averted during Aliyev's visit to Turkey, although Aliyev had threatened to mention the event in his address to the Turkish parliament but had been convinced not to do so. This series of events have had a substantial impact on Turkish-Azerbaijani relations, and have not been analyzed in detail to any significant extent. A review of the Turkish involvement is hence in its place, and gives the following picture.

The Turkish embassy in Baku had started to receive information on the upcoming Javadov affairs some three months before the coup attempt. The Turkish ambassador in Baku, Altan Karamanoglu, informed Aliyev of the forthcoming insurrection. The decision to inform Aliyev was, though, taken at a higher level. Then foreign minister Murat Karayalçin recalls that over two months before the event, Karamanoglu telephoned him, asking his superior what Turkey's role and position in all this was; Karayalçin answered that Turkey supported Aliyev. ${ }^{279}$ Although the two have different accounts of their meetings, it remains rather clear that the Turkish government was playing with open cards. President Aliyev, nevertheless,

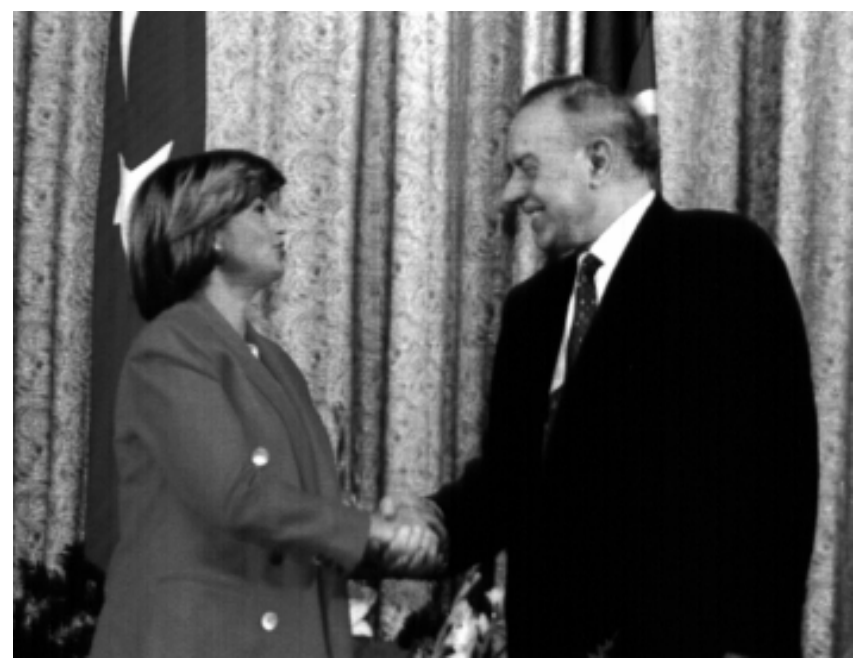

Figure Error! Unknown switch argument.: Çiller and Aliyev in Happier Times suspected Karamanoglu of involvement in the affair. After some time, the involvement of Ferman Demirkol, a Turkish citizen working for TIKA, in the affair, became clear: the Turkish intelligence agency informed the Baku embassy of this character's involvement on 28 February. The ambassador then called Demirkol to his office, informing him Turkey was in no way supporting any coup attempt and to pass this message on to Javadov. As Aliyev was preparing a

\footnotetext{
277 See Thomas Goltz, Azerbaijan Diary, op. cit. [134], p. 451.

278 The heavily censored report of the investigation into this scandal was published by the daily newspaper Radikal, prepared by Kutlu Savas.

279 See interview with Karayalçin in Hürriyet, 16 February 1998.
} 
trip to Copenhagen for a UN conference, and an extension to Pakistan, the Turkish embassy had found out through its intelligence officers in Azerbaijan that Aliyev might be the target of an assassination attempt, and warned the President. Once in Copenhagen, Aliyev met with President Demirel who informed him the Javadov's plan evidently was to assassinate Aliyev on his return, perhaps at the very airport. ${ }^{280}$ As a result, Aliyev decided to unexpectedly return early to Baku, and on 16 March launched an assault on Javadov's headquarters which later resulted in the insurgent's death. ${ }^{281}$

Although Turkey was instrumental in preventing the coup, the level of Turkish involvement in it have never become fully clear. The only evidence at hand is the accounts of the persons involved in the matter. According to Murat Karayalçin, only he, the Prime Minister and the President were informed at the government level, reducing the number of sources of information dramatically. Aliyev's claim that Karamanoglu was involved must naturally be taken seriously, although the picture presented by the Turkish authorities is fully reasonable. However, Karamanoglu is known to be one of Tansu Çiller's close associates; and certain circles in Turkey accuse Çiller of having been involved. ${ }^{282}$ Turkey claims only a few of its citizens were involved $n$ their own initiative; nevertheless Javadov went to Turkey a few months before the event and met with a number of people; his meetings are being investigated. Needless to say, it is in the interest of Turkey's credibility to investigate these events. Whatever the case, a certain amount of irreparable damage had been done; as Thomas Goltz puts it, the pan-Turkist honeymoon was over; 'although the 'special relationship' between Baku and Ankara would eventually be salvaged in part, the glow was gone forever' ${ }^{283}$ This deplorable episode in Turkish-Azerbaijani relations had one important consequence: Heydar Aliyev now abandoned his erstwhile policy of giving priority to Turkey in his relations with the west, of passing through Turkey in many matters. Now, Aliyev seeked more direct contacts with in particular the United States. There is also less of an imbalance in the relations between the countries. Aliyev has to a large degree started acting as Demirel's equal in later relations, and has had a more assertive policy. Nevertheless the Turkish government of Mesut Yilmaz, which came to power in Summer 1997, has gone out of its way to repair relations with Azerbaijan and to improve its relations with the Caucasus and Central Asia, relations that were to a large extent neglected during Islamist Erbakan's tenure in 1996-97. Although the 'glow' may be gone, Turkey and Azerbaijan need each other and need to rely on each other in the regional context. Hence the most lasting impact of the Javadov affair may have been to decrease Azerbaijan's deference to Turkey in their bilateral relations.

\section{Turkey and Armenia: Doomed to Animosity?}

Turkey’ relationship with Armenia has been conditioned by several factors which have impeded the creation of constructive relations between the two countries. The Nagorno-Karabakh conflict, as described above, has naturally played an important role. Two other, inter-linked issues have

\footnotetext{
${ }^{280}$ See interview with Demirel in Aksam, 26 February 1998.

281 The best account of the events and the Turkish involvement is a Turkish television program on private Channel D, entitled 32inci Gün, broadcast on 25 February 1998. A transcript of the program is available at http://www.softdesign.com.tr/32gun/dosyalar/dosya23.html.

${ }^{282}$ See eg. Faruk Bildirici’s biography of Çiller, Maskeli Leydi-Tekmili Birden Tansu Çiller, Istanbul: Ümit, 1998 (23rd edition) p. 322-323, where the author hints at Çiller’s involvement.

${ }^{283}$ Goltz, Azerbaijan Diary, op. cit. [134], p. 451.
} 
nevertheless had an equally important influence on the relations between the two countries. The first is the above-mentioned alleged Genocide of 1915, which Armenia has been seeking international and Turkish recognition for; the second is the territorial issue: Turkish suspicions of Armenian territorial designs on Turkey, engendered by Armenia's refusal to recognize the Turkish-Armenian border unequivocally.

\section{Initial Good Signs but Rapid Deterioration}

Despite these problems, the initial relations between the two countries proceeded relatively positively. At Armenia's independence, high-level meetings took place which seemed quite hopeful; indeed Armenia and Turkey pledged to develop trade relations and 'recognized the need to overcome psychological barriers to between the two peoples', referring of course to the legacy of the massacres of $1915 .^{284}$ Armenia even initially welcomed Turkey's good offices in the solution of the Nagorno-Karabakh dispute. The government of Levon Ter-Petrosyan, which was relatively liberal, hence abstained from pursuing the issue of 'Western Armenia' politically. However the regime did lobby actively for an international recognition of the Genocide, with the aim of forcing Turkey to recognize it as well. The Turkish refusal to recognize the Genocide is heavily linked with the territorial question. Indeed, a recognition on Ankara's part of the Genocide would result in a perception that Turkey has accepted Armenia's moral right to the territories in Western Armenia.

When Armenia gained independence, Turkey recognized all of the successor states 'within their respective borders', a clause that was certainly added for Armenia's sake. In fact, Turkey as a precondition for the establishment of diplomatic relations required Armenia to unconditionally recognize its present borders - referring to its Turkish border but also to that with Azerbaijan. In practice, this meant that Turkey urged Armenia to recognize the treaties of Moscow (16 March 1921) and Kars (13 October 1921) which recognize Turkish jurisdiction over the territories Armenia calls 'Western Armenia', and especially the Kars area which Russia ceded to Turkey with these treaties. Armenia refused to do so, arguing that the imposition of preconditions was unacceptable and has continued to call for the establishment of diplomatic relations without preconditions. The issue later came in the shadow of the Nagorno-Karabakh conflict, as Turkey identified Armenia as an aggressor in the conflict and started demanding the withdrawal of Armenia from the occupied territories in Azerbaijan as another prerequisite for the establishment of diplomatic relations. Armenia, of course, complains that it has no role in the occupation of these lands and therefore dismisses Turkey's demands. The Armenian opinion is exemplified by Nikolay Hovhannisyan: 'Armenia has never been an aggressor. It is well known that the Azeris began the war in Karabakh in 1991. Armenia is just trying to guarantee the security of the Armenian people in [Nagorno-Karabakh]. So all Turkish demands and preconditions were groundless and unacceptable for Armenia as humiliating for its national dignity’.285

In this context, Armenia urges Turkey to separate bilateral relations from the NagornoKarabakh problem. In the opinion of Ter-Petrosyan's advisor Gerard Libaridian, TurkishArmenian relations could follow the model of Turkish-Greek relations, that exist despite the

\footnotetext{
${ }^{284}$ See Graham E. Fuller, Turkey Faces East: New Orientations toward the Middle east and the Old Soviet Union, Santa Moinca, CA: Rand Corporation , 1992, p. 49.
} 
significant problems between the two countries, such as the status of the Aegean sea and Cyprus. $^{286}$ The fact is, however, that Armenia and Turkey have not established diplomatic relations in the more than seven years that have passed since Armenia's independence. The relations between the two countries worsened as Turkey, witnessing the Armenian advances in Nagorno-Karabakh and its surroundings, joined Azerbaijan in its economic embargo of Armenia, hence dealing the resource-poor country a heavy blow.

Nevertheless, in this context it should be noted that Ankara always made sure it left doors open for a rapprochement with Armenia. The fact that the Armenian government refused to recognize its borders with Turkey was by necessity alarming to Ankara. Turkish leaders, well aware of the feeling of most Armenians that they have at least a moral title to territories in Eastern Turkey, could not but interpret Armenia's refusal to recognize its borders as a proof of Yerevan keeping potential territorial claims on Kars and other regions of Northeastern Turkey to be unveiled at a later date. As long as Armenia does not recognize the 1921 treaties, the chances of an upgrading of relations is indeed slim.

\section{Moderate Governments Prisoners of their Own Predicaments}

Despite these fundamental differences, both Ankara and Ter-Petrosyan's moderate government have attempted to 'rescue' the bilateral relations, making occasional conciliatory gestures and keeping an informal dialogue. Hence on certain occasions Turkey did open its border with Armenia, thus allowing for humanitarian aid to pass through. In November 1992, Turkey even signed a deal by which it would have supplied 300 Million kilowatt hours of electricity to Armenia, which at the time was suffering from a severe energy shortage which threatened to leave thousands of people without heating in the winter. This deal received vehement criticism from the opposition and was seen as a stab in the back in Baku; thus already in January 1993, Turkey had to cancel the deal before it had even begun to be implemented. Another gesture on the part of Turkey was to invite Armenia to take part in the foundation of the Black Sea Economic Cooperation programme, which was from the beginning a Turkish initiative. Furthermore, Turkish business circles are pressuring the government to open trade relations with Armenia. Turkey does have an interests in opening the border gate from the Kars province to Armenia; according to various reports, the population of the Kars district is decreasing steadily and the economic underdevelopment of the region is a distinct problem. The opening of a border gate could have significant economic consequences for the Kars province, for example in terms of transit traffic. Presently, the Turkish business circles conducting business in the Caucasus are using Georgia as a bridge for their relations with Armenia. Indeed, they are doing so rather successfully. Any visitor to Armenia will be surprised by the level of Turkish economic penetration to the country, be it in terms of foodstuffs, machinery, or construction materials. In a way the embargo is then only partially working; as such it is as harmful to Eastern Turkey as it is to Armenia. In a sense, then, it is possible to speak of an era of moderate governments, both willing to improve relations, but unable to do so for both domestic and foreign policy-related reasons. In particular, it is often claimed, especially by Armenian observers, that Baku holds the key to Turkish-Armenian relations, as Heydar Aliyev has himself claimed more than once. In

\footnotetext{
285 Nikolay Hovhannissyan, The Foreign Policy of Armenia, Yerevan: Noyan Tapan, 1998, p. 32.

286 Tütüncü, “The Caucasus Policy of Turkey”, op. cit. [227], p. 195.
} 
particular, Aliyev has made it very clear that the realization of the Baku-Ceyhan pipeline is directly dependent upon Turkey's continued embargo on Armenia. The establishment of diplomatic relations, for example, would probably lead to an Azerbaijani distancing from the proTurkish policy that Aliyev is conducting.

\title{
The Strategic Context
}

Armenia's close relations with Russia and Iran must also be seen in the context of its relations with Turkey. Indeed, Armenia often denounces Turkey and Azerbaijan for conducting panTurkist policies. In the opinion of Hovhannisyan,

\begin{abstract}
The Armenians ... are considered to be one of the barriers against the Turkish expansion towards Central Asia. The golden dream of pan-Turkists of all generations was to either liquidate the 'Armenian Wall' standing on the way of Turkish expansion to the Turkic world or to transform it to an 'Armenian corridor'... A modus vivendi with Armenia would provide Turkey with a bridge to the area. But what kind of modus vivendi? ... It is clear that the turkish expansion, pan-Turkism and Turkic belt from the Balkans to China and Siberia is a great threat to all non-Turkic peoples and countries located on that vast territory. The common danger will stimulate a rapprochement of Russia, Armenia, Iran and other countries. ${ }^{287}$
\end{abstract}

Along the lines of this passage, powerful circles in Armenia are openly using the professed threat of pan-Turkism to build a stronger axis of cooperation between Armenia, Russia and Iran. The main aim of such an axis, naturally, would be to prevent Turkish influence from spreading in the Caucasus and Central Asia. For example, in November 1998 Armenian foreign policy advisor Aram Sarkissian openly spoke for the establishment of a 'geostrategic axis of stability' in the South Caucasus and adjacent areas. According to Sarkissian, 'Neither Russia nor Iran have a potential for expansion, nor do they threaten the security of other countries' ${ }^{288}$ The allusion to Turkey and pan-Turkist ‘expansionism' is obvious.

The advent to power of Robert Kocharyan in Armenia meant that the 'thaw' in relations that had been occurring during the later years of Ter-Petrosyan's rule was over. Where high officials of the Ter-Petrosyan government traveled to Turkey with short intervals, the new Armenian regime declared that it would openly pursue 'Hai Dat' - the Armenian Cause — in its foreign policy. Foreign minister Vartan Oskanian was cited as stating that Yerevan will 'put the recognition of the genocide on the agenda of a future dialogue with Turkey'. ${ }^{289}$ The Armenian Cause implies an aspiration to obtain theoretical recognition (at the very least) of Armenia's right to the territories where Armenians predominantly lived until 1915; hence this implied a turn to irredentism of Armenia's foreign policy. This policy turn was accentuated by the legalization in May 1998 of the Dashnaktsutiun, the radical nationalist party which formed the first Armenian republic, very powerful in the Diaspora, but was outlawed by Levon Ter-Petrosyan's regime due to the prohibition in the Armenian constitution of parties controlled from abroad: The Armenian Revolutionary Federation (the official name of the party) has its headquarters in Athens, presiding over more than a dozen regional branches, of which the Armenian branch is only one. However Ter-Petrosyan's move to outlaw the party, a mere six months before the 1995 elections, was

\footnotetext{
${ }^{287}$ Hovhannissyan, The Foreign Policy of Armenia, op. cit. [285], p. 39.

288 The Jamestown Monitor, 25 November 1998.

${ }^{289}$ The Jamestown Monitor, 22 April 1998.
} 
widely perceived to be more political than legal, the ARF being the strongest challenge to his rule. ${ }^{290}$ Whatever the reasons were, Turkey was considerably pleased by the banning of the virulently anti-Turkish party, which demands the recognition of the Genocide, the return of large territories in eastern Turkey as well as the entire Nakhjivan to Armenia, compensations from Turkey for the 1915 events, the annexation of Nagorno-Karabakh, and close ties with Russia and Iran. ${ }^{291}$ Indeed Ter-Petrosyan was trying to capitalize upon this factor in his attempts to improve relations with Turkey. But whereas the party had been outlawed and one of its leading figures, Vahan Hovhannisyan, jailed, Robert Kocharyan not only legalized the party but appointed Hovhannisyan as a top advisor, and included a prominent Dashnaks, Levon Mkrtchian, in his cabinet. Presumably Kocharyan's move was a reply to the ARF's backing of his candidacy in both rounds of the presidential election of 1998. However, Kocharyan has always been close to the ARF, which he allowed to operate freely in Nagorno-Karabakh when he was the president of the self-proclaimed republic until his appointment as Armenia's prime minister. ${ }^{292}$ The ARF, after all, dominated the legislature of Nagorno-Karabakh ever since its declaration of independence.

In terms of relations with Turkey, the advent to power of Kocharyan meant a drastic backlash as compared to the constructive atmosphere that had painstakingly been established despite the significant problems existing between the two countries. However, Kocharyan did not close the door to Turkey; just like Ter-Petrosyan, he was forced to acknowledge the importance of Turkey for Armenia and the need to keep some form of dialogue open despite the less compromising stance of the new Armenian leadership. In the words of Nikolai Hovhannisyan, the aim of Armenia is 'not to confront Turkey, but to engage it'. ${ }^{293}$ Given the recent developments in Armenia and Turkey's renewed efforts to exert influence in the Turkic world, any substantial improvement of relations with Armenia seems elusive.

\section{Implications for Turkey in the CIS and Regional Power Alignments}

In a way the Nagorno Karabakh conflict can be seen as a test case for Turkey's ability in the eatly 1990s to act as an independent regional power in the Caucasus and Central Asia. It seems likely, moreover, that analysts in Tashkent or Almaty have taken interest in Turkey's activities with regard to the conflict. And clearly, the Turkish record seems to dismiss any illusion that may have been existing about Turkey as a regional leader. But then again, what are Turkey's interests in the region? Despite the rhetoric of the early 1990s of a 'Turkic 21st century', Turkey quickly overcame any illusions of its own power and capacities, and its current policy is a distinctively more realistic one. ${ }^{294}$ Although in the longer term Turkey certainly intends to expand its relations with the Central Asian republics, it has no illusion of openly replacing Russia in the short run as the dominant power in the region. Rather, Turkey's interest for the time being lies in expanding its cultural, political and economic relations with the Turkic republics. In this framework, Turkey

\footnotetext{
290 For a useful overview of the Dashnak party, see Emil Danielyan, ”Banned Opposition Party has Deep Roots”, in Transition, vol. 3 no. 3, 21 February 1997, pp. 44-47.

${ }^{291}$ Demands which were reiterated at a congress in 1995. See The Jamestown Monitor, 8 December 1995.

292 See The Jamestown Monitor, 7 May 1998.

${ }^{293}$ Hovhannissyan, The Foreign Policy of Armenia, op. cit. [285], p. 42.

${ }^{294}$ For a discussion on Turkey’s achievements, see Bölükbasi, ,’Ankara’s Baku-Centered Transcaucasia Policy”.
} 
is pursuing a number of policies which, although not reaching the headlines, are instrumental in bringing the people of the Turkic republics and Turkey itself closer, and the importance of which will only become apparent in the long run. One main example is that Turkey is providing scholarships for thousands of Azerbaijani and Central Asian students in Turkish universities, a gesture which will be instrumental in bringing about an élite in these countries which is familiar with and favorably disposed towards Turkey. Secondly Turkey is projecting its mass media into the region, particularly to Azerbaijan where a number of Turkish newspapers are being published. Measures of this kind, given some years and coupled with increased economic interaction, are certain to establish warm and beneficial relations between Turkey and its 'lost cousins'. The relative setback in Nagorno Karabakh has to be seen as only a part of this puzzle of relations.

The conflict in Nagorno Karabakh at an early stage shattered the illusions of certain Turkish policy-makers about the capacities of their country with regard to its relations with its 'lost cousins' of the Caucasus and Central Asia. Indeed, as if subjected to a cold shower, the Turks which had not done so realized the complexity of their country's relations with the United States, Western Europe, Russia, and the Middle East, and the constraints upon it that prevented Turkey from pursuing a truly independent policy in the region. Turkey found itself involved in a myriad of liabilities, as it was compelled to take into account the stance of the West and that of Russia while formulating its policy in the Caucasus. The problems of formulating a policy towards Chechnia deepened this perception. In view of the difficult conditions it was subjected to, Turkey nevertheless managed to keep its relations with all involved powers, avoiding to compromise its position in any center where that would have been to its detriment. The price Turkey had to pay for this was a popular dissatisfaction in Azerbaijan and a manageable loss of prestige in the Muslim republics of the former Soviet Union. Thus although momentarily Turkey did not show its ability to assert its influence in the Caucasus and Central Asia, it continued to maintain a pivotal role in the region, being the main link of these countries with the West and posing a developmental model for these countries, a quality which is not to be underestimated, as many more rounds are left to be played in the struggle for influence in this emerging region of world politics. In view of the larger geostrategic position of Turkey, which after all had other priorities than the Caucasus to look after as well as substantial internal problems, this could be termed a fair deal. 


\title{
6
}

\section{Iran: In the Pitfalls of History}

\begin{abstract}
I looked at him, shaken. What was right, what was wrong? True, the Turks were Sunnites. And yet my heart longed to see Enver coming to our town. What did they mean? Had our martyr's blood really flowed in vain? 'Seyd', I said, 'the turks are of our blood. Their language is our language. Turan's blood flows in our veins. Maybe that is why it is easier to die under the Half Moon of the Khalifs than under the Czar's cross'.

Seyd Mustafa dried his eyes: 'In my veins flows Mohammed's blood', he said coolly and proudly. 'Turan's blood? You seem to have forgotten even the little you learned at school. Go to the mountains of the Altai, and yet further to the border of Siberia: who lives there? Turks, like us, of our language and our blood. God has led them astray, and they have remained pagans, they are praying to idols. If these Jakuts or Altai-men were to become powerful and fight us, should we Shiites be glad of the pagan victories, just because they are of the same blood as we?

'What shall we do, Ali Khan? I do not know'. 295
\end{abstract}

As the Soviet Union fell apart in 1991, it was widely expected that Iran and Turkey would enter into a rivalry for influence in the Caucasus and Central Asia - an expectation which to a large extent has become reality, despite official efforts from both sides to deny this. ${ }^{296}$ In particular, the Turco-Iranian struggle has taken the form of a struggle between 'models'-Turkey presenting a secular, Western-oriented democratic model, while Iran proposes a radical Islamic, anti-Western outlook with its own particular regime, which however allows for a substantial degree of democracy. In this respect, and perhaps except for Tajikistan, Turkey currently seems to have the upper hand, as most Caucasian and Central Asian leaders expressed sympathy for the Turkish model, as viewed in chapter 7, but have been very hostile to political Islam and therefore have refrained from too close relations with Iran. In this struggle for influence, the Caucasus has taken a special place. The region is as noted at the outset of this study the historical meeting point of three empires: The Russian, the Ottoman Turkish, and the Persian. During much of history, Iran has considered the Transcaucasus to be part of its sphere of influence and has played the role of a

\footnotetext{
${ }^{295}$ Kurban Said, Ali and Nino, New York 1972, reprinted by Robin Clark, 1991, p. 74. This particular quote was first brought to my attention through S. Enders Wimbush, ”Divided Azerbaijan: Nation Building, Assimilation, and Mobilization between Three States”, in William O. McCagg and Brian D. Silver, Soviet Asian Frontiers, New York: Pergamon Press, 1979, pp. 61.82.

${ }^{296}$ For an overview of the competition between Turkey and Iran for influence in Central Asia and the Causasus, see John Calabrese, "Turkey and Iran: Limits of a Stable Relationship” in British Journal of middle Eastern Studies, vol. 25 no. 1, May 1998, pp. 75-94; Philip Robins, "Silent Competition: Iran and Turkey in Azerbaijan and Central Asia," in Etniske Konflikter i Sentral-Asia of Kaukasus, Norwegian Institute for International Affairs, No. 172, (September 1993), pp.111-123.
} 
hegemon in the area. With the disappearance of Russian control, such historical affinities reemerged in Tehran.

Based on ethnolinguistic and religious affinities but also on strategic considerations, it seemed logical that both Turkey and Iran would give priority to Azerbaijan in trying to gain influence in the Caucasus. A priori, this seemed a logical conclusion, and the Azerbaijani leadership initially hoped that it would be able to use the Turco-Iranian rivalry to its own benefit. Turkey is closely tied to Azerbaijan in terms of language, ethnicity and culture. The Azeris also share many elements of Persian culture and, more important, are - like the Iranians - predominantly Shia Muslims, whereas the Turks are mainly Sunnis. ${ }^{297}$ Azerbaijan and Iran also have very strong historical links. Azerbaijan has for most of its history been a part of the Persian empire, an arrangement which came to an end with the Russo-Persian wars of the first half of the nineteenth century. Turkic dynasties have even ruled Persia at different times; the Safavid empire, which instituted Shia Islam as state religion in Iran, was Azeri in origin. ${ }^{298}$

Thus the Azeris share common denominators with both Iran and Turkey. Furthermore, to the extent that this was the intention of these two regional powers, Azerbaijan would be the best country to choose in order to project power and influence into the Caucasus. Besides being overwhelmingly Muslim, in contrast to both Armenia and Georgia, Azerbaijan is the largest of the three Transcaucasian countries, with a population of almost 8 million; moreover, it is rich in natural resources, primarily oil, which

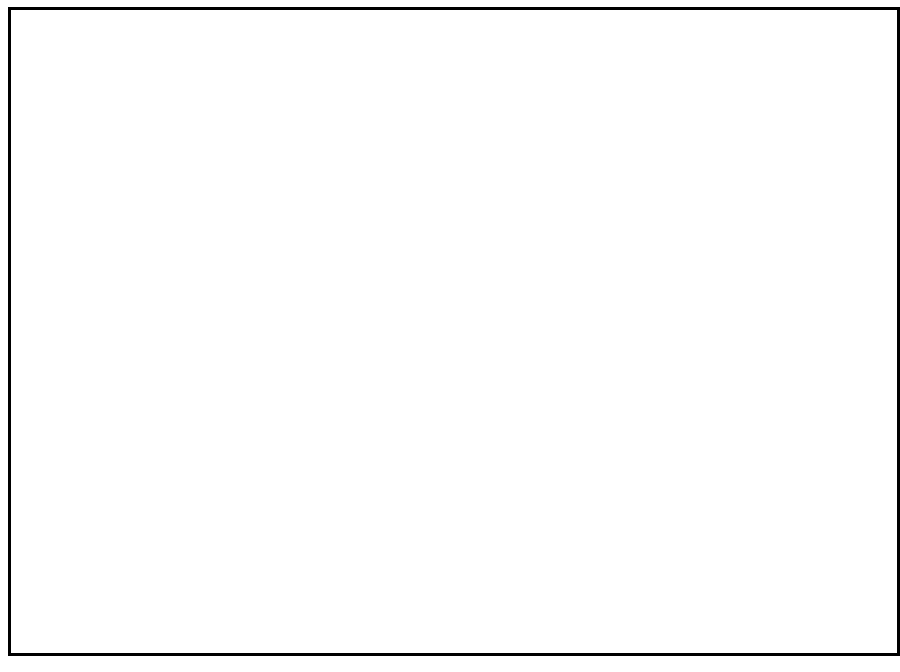

Figure Error! Unknown switch argument.: Presidents Rafsanjani and Demirel neither of the other two possesses.

Geopolitically, Iran enjoys an over-700-kilometer-long border with Azerbaijan, which gives it the important advantage of direct access to that country. Turkey has a mere $7 \mathrm{~km}$ border with Nakhjivan, which is separated from mainland Azerbaijan by Armenia.

A further circumstance, however, complicates the Iranian relationship with its northern neighbor. The majority of the Azeri nation is resident in northern Iran, not in the Caucasian republic. Whereas the Republic of Azerbaijan contains roughly six million Azeris, between 15 and 20 million are estimated to live in Iran. This fact has been an important reason for the ambivalence of Iran towards Azerbaijan. Turkey has consistently_both officially and by its

\footnotetext{
297 Although the Turkish population is mainly Sunni Muslin, it should be noted that over 20\% of the Turks belong to the Alevi sect, which belongs mainly to Twelver Shii Islam, but is based on a syncretistic belief particular to Anatolia, and hence very different from Iranian Twelver Shiism.

${ }^{298}$ For the history of Azerbaijan, and the contacts between the two parts of the Azeri nation, see Tadeusz Swietochowski, Russia and Azerbaijan, op. cit. [8]. See also by the same author, Russian Azerbaijan, 1905-
} 
actions - put Azerbaijan in first place in its relations with post-Soviet states (see chapter 5); Iran has not committed itself in the same way. Turkey, after a period of uneasy neutrality, openly took Azerbaijan's side in Azerbaijan's armed conflict with Armenia over the Nagorno Karabakh enclave; Iran has had a very ambivalent and, at first sight, illogical policy towards the conflict. Actually, given the militant Islamic rhetoric and policy of the country, Iran could have been thought to be the first country to rush to the support of the Azeris, fellow Shia Muslims, in their confrontation with the Christian Armenians.

Unfortunately for the Azeris, nothing of this sort happened. Whereas Iran declared itself ready to mediate in the conflict, it did not in any way support the Azerbaijani side. Quite to the contrary, Iran has constantly sought to cultivate and improve its relations with Armenia. Whereas Turkey joined Azerbaijan's embargo of Armenia and Nagorno Karabakh, Iran is one of Armenia's main trading partners, and according to recent reports it is also very active in trading with the Karabakh Armenians as well, being the major supplier of foodstuffs and other commodities to the enclave. ${ }^{299}$ In fact, Iranian policy and conduct towards Transcaucasia are heavily colored by what can be termed an "Azerbaijan factor". To understand the underlying determinants of the policy and how it is shaped, it is necessary to first analyze the origins and evolution of the Azerbaijan question during this century.

\section{The Azerbaijan Question Up To The Soviet Breakup}

The Russo-Persian wars of the first half of the nineteenth century ended in a decisive Persian defeat, which was finally confirmed by the Turknianchai treaty of $1828 .{ }^{300}$ This treaty and subsequent protocols to it demarcated a border between the two empires along the Araxes River - a line that cut through the lands inhabited by the Azeri people. Iran was naturally not satisfied with this situation and found an opportunity to reverse it at the Paris peace conference of 1919. This was a time when the central power in Russia was weak, and Moscow was consumed with the 1917 Bolshevik revolution. In effect, it had lost control over Transcaucasia and actually recognized the independence of the three states of Georgia, Armenia and Azerbaijan. ${ }^{301}$ However, the Iranian claims at the Paris conference were left unanswered, and instead the three short-lived "democratic" republics of Transcaucasia lived on for three difficult years, only to be incorporated into Soviet Russia in 1920-21, after the Bolsheviks had secured power in Moscow and could reassert control over its peripheries. ${ }^{302}$ After these events, Iran seemed to accept the loss of Transcaucasia, formalizing the border with the Soviet Union by a treaty in $1921 .^{303}$

Naturally, the division of Azerbaijan between two empires was a disaster for the Azeri nation. Families were broken up, old patterns of contact, culture and trade were destroyed, and the very

1920: The Shaping of National Identity in a Muslim Community, (Cambridge: Cambridge University Press, 1985).

299 "Enclave Builds a Lifeline Out of Azerbaijan," International Herald Tribune, September 20, 1996.

${ }^{300}$ On the Russo-Persian wars, see Muriel Atkin, Russia and Iran 1780-1828, Minneapolis: University of Minnesota Press, 1980.

${ }^{301}$ Firuz Kazemzadeh, The Struggle for Transcaucasia, Oxford: Oxford University Press, 1951.

${ }^{302}$ For an overview of the period, see Stephen Blank, ”The Transcaucasian Federation and the Origins of the Soviet Union, 1921-22,” in Central Asian Survey, No.4, 1990.

303 See Fred Halliday, "Condemned to React, Unable to Influence: Iran and Transcaucasia," Transcaucasian Boundaries, John F. Wright, Suzanne Goldenberg and Richard Schoefield, eds., (London: UCL Press, 1996), p.75. 
survival of the nation was endangered, given the long period of time that the two parts of Azerbaijan were separated from each other. In particular, seventy years of Soviet rule created important differences in lifestyle and identity between Iranian- and Russian-ruled Azeris. As Tadeusz Swietochowski describes it, the Azeri people on both sides constantly sought to keep up relations over the border. This was particularly successful during the Baku oil boom in the late nineteenth century, when thousands of unemployed Azeris from Iran crossed the border to seek temporary employment in the oil industry. ${ }^{304}$ At certain points, Swietochowski notes that the contacts between North and South Azerbaijan were so close that folk tales and songs from one side spread quickly to the other.

These interactions continued during the period of World War I. As one observer states, due to the lack of central authority in Iran at the time, there was actually no political frontier separating the two Azerbaijans, ${ }^{305}$ and hence no obstacle to contact. From 1921 onwards, however, this period of instability ended in both Iran and the newly formed Soviet Union, and the border between the two states became increasingly closed to population flows. Consequently, the two parts of the Azerbaijani nation were separated for decades, indeed prevented from interacting with one another until the late 1980s.

The birth of the Azerbaijani Democratic Republic in 1918 did not pass unnoticed in Iranian Azerbaijan. An autonomist movement emerged under the leadership of Sheykh Muhammad Khiabani, who announced the formation of a local government. Khiabani seems to have been in favor of a reunion of both Azerbaijans, under the name of Azadistan. ${ }^{306}$ However, this movement was crushed before acquiring sizable proportions. According to several authors, however, Khiabani's movement carried more of a general democratic reformist orientation than a national one. Indeed, Nassibli claims that the movement had no national character. ${ }^{307}$

The Azerbaijan question came back to the agenda during World War II, when a new political vacuum was created in Iran after the British and Russian invasion of the country in $1941 .{ }^{308}$ This vacuum was quickly exploited by Azeri nationalists, who managed to establish a short-lived Azerbaijani republic in $1945 .{ }^{309}$ Although many observers have argued that this was mainly the creation of Russian intervention, it seems clear that it based on a strong, comparatively wellorganized Azeri nationalist clique in Iranian Azerbaijan, without which it would never have come into existence. Naturally, the aggressive and interventionist Soviet policy towards Iran was equally important for its formation. The Azeris had preserved their ethnic identity and displayed a significant level of group cohesion; however the popular participation in the autonomy struggle was very limited. Fred Halliday, in this context, sees the Azeri nationalism of the time not as a secessionist attempt but rather as a struggle for autonomy within the framework of the Iranian

\footnotetext{
${ }^{304}$ Swietochowski, Russia and Azerbaijan, op. cit. [8], pp.20-24.

${ }^{305}$ Halliday, op. cit. [300], p. 75.

306 See Firozeh Nahavandi, ”Russia, Iran and Azerbaijan: The Historic Origins of Iranian Foreign Policy,” in Bruno Coppetiers, ed., Contested Borders in the Caucasus, Brussels: VUB Press, 1996.

307 Nasib Nesibzade (Nassibli), Iranda Azérbaycan Mésélési: XX Ésrin 60-70-ci Illéri, Baku: Ay-Ulduz Néshriyyatí, 1997, p. 125.

${ }^{308}$ A good account of the Azerbaijan question in this era is Touraj Atabaki, Azerbaijan: Ethnicity and Autonomy in Twentieth-Century Iran, British Academic Press, 1993.

309 This episode has been the subject of quite some academic attention. See, for example, Louise Fawcett, Iran and the Cold War: The Azerbaijan Crisis of 1945, Cambridge: Cambridge University Press, 1992.
} 
state. ${ }^{310}$ When Soviet support was withdrawn and the Tabriz-based republic crushed by the central government, measures were taken to preclude the renewal of secessionist claims. Iranian Azerbaijan was administratively divided into two in 1946, with Tabriz and Rezaye as provincial centers. ${ }^{311}$ This policy, repeated in 1993 when a third Azeri province around Ardebil was created, shows the eagerness on the part of the Iranian authorities, whether Pahlavi or republican, to prevent the emergence of any signs of secessionism among the Azeris. The Pahlavi state's repression in fact forced many Azeri intellectuals to seek refuge North of the Araxes, where they became an important element in the North Azerbaijani intelligentsia and remain so today. ${ }^{312}$

Nasib Nassibli's account of Iranian Azerbaijan in the 1960s and 1970s shows that the presence of the Shah's repressive structures during this period was more pronounced than in other parts of Iran; showing the Pahlavi regimes fear of the development of Azeri nationalism as well as political opposition in general in the Azeri-populated areas. ${ }^{313}$ The 1960 s were indeed a time when the Azeris of Iran rediscovered their culture, language and music and accorded an increasing amount of importance to it. ${ }^{314}$ Meanwhile, the Pahlavi regime was actively propagating a historiography that denied early Turkic presence in Iran and downplayed the Turkic element in Iranian history. A Pan-Iranist and monarchist ideology was promoted, which emphasized the religious and cultural affinities and downplayed linguistic and ethnic ones. The regime prevented the use of the Azeri language, especially in the education system. ${ }^{315}$ The tangible improvement of the economic situation in Iranian Azerbaijan during this period through the extraction of oil was a factor that helped the regime to conduct these policies without major unrest.

What is more difficult to explain is what has happened to Azeri nationalism since then, for the events during the Islamic revolution of 1978-79 show little sign of it. This was a period when many peoples - in the very multiethnic Iran—voiced their claims for national autonomy. Clearly, the Azeris are by far the largest non-Farsi-speaking ethnic group in Iran; however, smaller nations such as the Kurds or Baluchs were much more vocal than the Azeris. This fact can be explained by a number of factors. First of all, the Azeris are Shiite Muslims, unlike most Kurds, Arabs and other minorities in Iran. Hence the switch from a Persian-oriented to a Shiite-oriented state meant an actual rise in the prospects of the Azeris. Furthermore, the new constitution of the Islamic Republic enabled the Azeris to use their own language and express their own culture to a distinctly greater extent than had been the case under Pahlavi rule. The new state was one in which they were, so to say, full members. Secondly, the post-war era meant an increased integration of the Azeris into the political and economic life in Iran. One must also see that most Azeris in Iran, given their history as its rulers in certain periods, consider Iran to belong to them as much as to the Persians_certain Azeri political movements actually demand, not a unified Azeri state, but the incorporation of northern Azerbaijan into Iran. ${ }^{316}$ Indeed, even among the

\footnotetext{
${ }^{310}$ Halliday, op. cit. [300], pp. 76-79.

${ }^{311}$ See Nahavandi, ”Russia, Iran and Azerbaijan”, op. cit. [306], p. 159.

312 See discussion in David Nissman, The Soviet Union and Iranian Azerbaijan: The Use of Nationalism for Political Penetration, Boulder: Westview Press, 1987, pp. 41-47.

${ }^{313}$ Nesibzade, Iranda Azérbaycan Mésélési, op. cit. [307], p. 123.

${ }^{314}$ Nesibzade, op. cit. [307], quoting É. R. Nabdel, Azérbaycan vé Més'alye Melli, Tehran, 1979.

${ }^{315}$ Nesibzade, Iranda Azérbaycan Mésélési, op. cit. [307], p. 134.

316 "Irredentist Campaign Among Azeris in Iran” OMRI (Open Media Research Institute, Prague) Daily Digest, 3 September 1996. The option of incorporating Northern Azerbaijan into Iran, although sympathetic to the Iranian rulers, is seen by some observers as being as dangerous for Iran as Azerian secessionism; the addition of
} 
highest positions of the Islamic republic, a significant number of Azeris are found. It should be noted, nevertheless, that in the religious sphere the Azeri clergy have often been at odds with Khomeini and his followers, some allying themselves with the latter's opponent, Shariat Madari. ${ }^{317}$

Halliday also puts forward two other arguments. The first is that the failure of the 1945-46 experience might have served as a lesson to the Iranian Azeris, making them realize that their only possibility was to exist within the Iranian state. The second argument is that the main grievances of the Azeris are with the Kurds, not with the Iranian state, and that the Azeris would not opt for autonomy, fearing that the Kurds would then do the same. ${ }^{318}$ However, these arguments are difficult to fit into the picture of worldwide ethnic mobilization and conflict. Population groups are usually not discouraged by past failures. If such experiences do have an impact, they rather tend to accentuate ethnic mobilization and group cohesion. Furthermore, it does not seem as if ethnic mobilization usually follows such a logical or rational pattern as would be required for this argument to be valid. It is conditioned more by emotions than a rational calculation of benefits. ${ }^{319}$

This is not to say that unification movements are nonexistent. Quite to the contrary, reports seem to show that the movement is on the rise in both parts of Azerbaijan, perhaps because the popularity of the Islamic regime is falling. A South Azerbaijan National Liberation Committee (SANLC) exists, operating from the Azerbaijani republic. The extent of its following is not known; however, its existence has been another thorn in Iranian-Azerbaijani relations, and Iran has forced Azerbaijan to profess its "neutrality" towards the movement. ${ }^{320}$ Faced with this harsh reaction, the Azerbaijani government has been compelled to restrict the activities of the South Azerbaijani nationalists on its territory. In fact, the actual level of Azeri nationalism in presentday Iran is very little known. The information that reaches the West might be only the tip of an iceberg. However, the harsh repression of any Azeri nationalist tendencies, as well as the Iranian state's policy towards the Azerbaijani republic, seems to show that it constitutes a far larger problem for the Iranian leadership than can be observed—or it is perceived as such in Tehran.

\section{The Perceived Azerbaijani Threat}

If Iranian policy towards the newly established Azerbaijani state seems illogical at first, it can be explained by domestic considerations. With economic indicators pointing downward ${ }^{321}$ and with a constant fear of irredentism in its multiethnic society, the Iranian government was less than pleased by the emergence of an Azerbaijani state to its immediate north. Matters were not made easier by the fact that this Azerbaijani republic was endowed with large resources of oil and

six million Azeris would actually put the latter more at par demographically with Farsi-speakers in the Iranian population.

317 See Nahavandi, ”Russia, Iran and Azerbaijan”

${ }^{318}$ Halliday, op. cit. [300], p. 80.

${ }^{319}$ For a discussion of ethnic mobilization, see for example Ted R. Gurr and Barbara Harff, Ethnic Conflict in World Politics, Boulder \& Oxford; Westview Press, 1994.

320 ”Iran Demands Extradition”, OMRI Daily Digest, 10 September 1996.

${ }^{321}$ For an overview of the problems of Iran, see Abmed Hashim, The Crisis of the Iranian State, (Adelphi Paper, No.296, 1995). 
natural gas, which would be likely to transform it into what some observers have termed "the Kuwait of the Caucasus. ${ }^{322}$

The existence of a large Azeri minority in Iran could have been an incentive for the Iranian rulers to support the Azerbaijani republic, in order to preempt criticism from its own Azeri minority. The Iranian leadership, however, does not seem to have reasoned along these lines, instead, they saw fit to counteract the interests of the Baku government in every possible way. This, despite the fact that not only the Azeris in Iran, but overwhelming public opinion, demanded that the government openly take the Azerbaijani side against the Armenian "infidels." ${ }^{323}$

This circumstance can be explained by the perception of the threat that Azerbaijan posed to the Iranian regime. In fact, the leaders of the Islamic Republic seem to have seen the emergence of an Azerbaijani republic as a long-term threat to the integrity of the Iranian state, rather than as a short-term threat. What they feared was not an immediate upheaval of the Azeri population in solidarity with their brethren, urging Tehran to intervene in Karabakh. The Azeris in Iran are, after all, quite well-integrated into the Iranian society, have a comparatively weak Azeri identity, and for the most part feel themselves at least as much Iranians as Azeris. As stated above, there are even Azeri movements in South Azerbaijan that urge the integration of the Azerbaijani republic into Iran. However, it is difficult to assess whether these movements are genuine or a mere fabrication of the Tehran regime.

The high level of integration of the Azeris is also a reason why the Iranian government saw no imminent danger in pursuing an anti-Azerbaijani policy. The actual threat that Azerbaijan was perceived as posing to the regime was that, if Iran's economic condition (and by extension its social cohesion) deteriorated, the national identity of the Azeri minority in northern Iran would grow in proportion to popular dissatisfaction with Tehran's policies. This would be all the more dangerous if the Azerbaijani republic simultaneously prospered thanks to its oil revenues.

An illustration of the degree of Iranian fear of Azeri irredentism occurred in the summer of 1993. At this point, the Azeri military performance in Karabakh was plainly a disaster, and Armenian forces conquered territories of Azerbaijan proper east and south of Karabakh. In October, the situation became critical for Iran, as the Armenians pushed towards the Iranian border, threatening to send a massive refugee flow into the country. Indeed, a number of Azeri refugees did swim across the Araxes, where they were welcomed by their ethnic kin on the other side. The Iranian regime reacted quickly and moved to set up refugee camps for the fleeing Azeris - but on Azeri territory. Hence the refugees were forcibly moved back to Azerbaijan, where Iran already by November claimed to harbor over 40,000 people. ${ }^{324}$ Perhaps the main reason for this move seems to have been a fear on the part of the Iranians that allowing Azeri refugees to stay in Iran and fraternize with the Iranian Azeris could pose a danger. If the Iranian Azeri community became aware of the atrocities suffered by their kin in the war, there would be a high risk of increased pressure on the regime to intervene on Azerbaijan's side; even more dangerous would be the risk of heightened Azeri ethnic mobilization in Iran in solidarity with the northern Azeris in their struggle against the Armenians.

\footnotetext{
${ }^{322}$ Chris Kutschera, "Azerbaijan: The Kuwait of the Caucasus?" The Middle East, London, March 1996.

${ }^{323}$ Abdollah Ramezanzadeh, "Iran's Role as Mediator in the Nagorno-Karabakh Crisis," Contested Borders in the Caucasus, Bruno Coppetiers, ed. (Brussels: VUB Press, 1996).

${ }^{324}$ BBC Summary of World Broadcasts, 13 November 1993.
} 
The perception of threat, then, was so strong that Iran saw fit to set up expensive refugee camps outside its own territory. The action cannot be explained by simple humanitarian concern, as the easiest solution then would have been to set up camps on the Iranian side, where they presumably would be safer from Armenian attack. One should not, nevertheless, neglect the importance of economic factors in the decision. Iran, after all, already harbors over two million refugees from Afghanistan and Iraq. The prospect of additional thousands of refugees must have been an incentive to try to keep them outside Iran. However, these economic considerations as a whole seem to be secondary as far as the refugee issue is concerned. The speed with which the refugees were relocated indicates the perception in Tehran of a potentially explosive situation. As Dilip Hiro has noted in his excellent book Between Marx and Muhammad, Iranian President Ali Hashemi Rafsanjani became aware of the Azerbaijani threat:

Rafsanjani realized that in the long run, Azeri nationalism would prove as problematic for the Islamic regime in Tehran as it was proving then for the Communist administration in Moscow....The emergence of a strong, independent Azerbaijani republic — whether Islamic or not — would fan the flames of Azeri nationalism within Iran. ${ }^{325}$

Thus from the time of Azerbaijan's independence at the breakup of the Soviet Union, Iran had a wary attitude towards the Azeri republic. Nevertheless, until mid-1992, strong currents in Iran were highly supportive of Azerbaijan. Iran attempted serious mediation efforts, not without success, as will be discussed below. Furthermore, Iranian nationalists have pressured the regime to side with Azerbaijan, reasoning that the Azeris of Azerbaijan are actually Iran's own citizens, as the entire Azerbaijan belongs to Iran. ${ }^{326}$ Several radical newspapers have also urged the government to condemn Armenia. ${ }^{327}$ The early developments in Baku, prompted by the war, were only instrumental in turning Iran's wariness into outright enmity.

As the leader of the Azerbaijan Popular Front (APF), the historian Abulfaz Elçibey, came to power in June 1992, Azerbaijan turned increasingly towards Turkey. Indeed, Elçibey was decidedly pro-Turkish, secularly oriented, pan-Azeri and vehemently anti-Iranian. This meant that Tehran had exactly the kind of government in Baku that it did not wish to have. President Elçibey did not show any diplomatic tact either. On several occasions, he blasted Iran as a doomed state and predicted that within five years Azerbaijan would be reunited. ${ }^{328}$ This policy was hardly the most effective way of allaying Iran's suspicions. Nevertheless, the Elçibey period turned out to be very short in Baku, as the government proved incapable of dealing with the Karabakh war and attracted at least as much enmity from Moscow as from Iran. Moscow’s direct involvement on the Armenian side has been proven by eyewitness accounts and testimonies of individual Russian soldiers. $^{329}$

Allegations of Iranian involvement have also been voiced by Azerbaijan, especially concerning the coup d'état that overthrew Elçibey in the summer of 1993. Azeri conspiracy theorists even see

\footnotetext{
${ }^{325}$ Dilip Hiro, Between Marx and Muhammad-The Changing Face of Central Asia, London: Harper-Collins, 1997, p.293.

${ }^{326}$ Takmil Homayun, "Negahi be Gharabagh Dar Masire Tarikhe Iran."Motaleaat Asiaye Markazi wa Ghafghaz, Vol.2, No.1, Summer 1993. Quoted in Ramezanzadeh, ”Iran's Role As Mediator ”, op. cit. [323].

${ }^{327}$ Foreign Broadcast Information Service (FBIS), South Asia, (March 10,1992). Harvard University John F. Kennedy School of Government, January 1994.

${ }^{328}$ Dilip Hiro, ”The Azerbaijan Question”, The Nation, 14 September 1992.

${ }^{329}$ Thomas Goltz, ”Letter from Eurasia”, op. cit. [211].
} 
a joint Russo-Iranian action behind that coup. ${ }^{330}$ Although no significant evidence exists to prove such allegations, it remains clear that during Elçibey's rule, Iran drifted towards close contacts with Armenia. However, Iran's support fell short of any military involve-ment of the Russian type. Rather, Iran supplied Armenia with necessary goods and energy, hence counteracting the Turco-Azeri embargo on the country—which actually eliminated Azerbaijan's main bargaining chip against Armenia. Iran is today Armenia's largest trading partner. The Azeris also suspect Iran of involvement in support of radical Islamic political movements in Azerbaijan, as well as of encouraging ethnic unrest among Azerbaijan's Talysh minority, which lives near the Iranian border. Thus the curious legacy of the Elçibey era: an Islamic fundamentalist state, Iran, ended up supporting Christian Armenia against Muslim Azerbaijan.

When Elçibey was toppled in June 1993 and replaced by Heydar Aliyev, Azerbaijan's Communist-party leader during the Brezhnev years and a former Politburo member, the time seemed ripe for a rapprochement between Azerbaijan and Iran. Aliyev quickly moved to restore some kind of balance in Azerbaijan's foreign relations, seeking to distance himself from the tight alliance with Turkey that Elçibey had built, in order to diversify international contacts. His first step was to normalize relations with Russia, by acceding to the CIS. Further, Aliyev also brought his policy more into line with Tehran's. Previously, Aliyev had not refrained from anti-Iranian statements. ${ }^{331}$ However, his sense of political tact and his awareness of Iran's importance for Azerbaijan's security led him to follow a conciliatory path.

In fact, immediately before acceding to power, Aliyev was the leader of Nakhjivan, the Azerbaijani enclave encircled by Armenia, Iran and Turkey. During the war, Aliyev had ruled Nakhjivan autonomously from Baku and had built good personal relations with Iranian leaders, unilaterally concluding several trade and energy deals with Iran without seeking Elçibey's approval. In fact, Iran gave financial aid to Nakjivan and put pressure on Armenia to refrain from attacking the enclave - something which clearly could have led to an escalation of the conflict, as Turkey considers itself a guarantor of Nakhjivan's security by its 1921 treaties with the Soviet Union. As the leader of Azerbaijan, Aliyev continued to try to bring Azerbaijan closer to the Islamic world. He traveled repeatedly to Tehran and Riyadh, ${ }^{332}$ and even tried to enhance his Islamic credentials in spite of his having been in the forefront of Soviet atheist campaigns of the 1970s, when he was chairman of Azerbaijan's Communist party.

Despite these developments, the relations between Azerbaijan and Iran have not improved significantly, and the basic guidelines of Iranian policy towards Azerbaijan do not seem to have changed. When Azerbaijan concluded the so-called "deal of the century" in 1994 with a consortium led by Western oil companies, Iran was initially given a 5-percent share of the deal. In April 1995, the United States forced Azerbaijan to exclude Iran from the deal, which naturally made the Iranians furious, accusing Aliyev of being a tool of the "great Satan." Iran immediately

\footnotetext{
${ }^{330}$ Interestingly, certain Turkish observers claim that Turkey was involved in the coup. As Elçibey's fall from power was perceived as a great setback for Turkey in the entire Caucasus, such statements seem highly illogical. The argument, however, is that Turkey had realized Elçibey's inability to handle the government, and hence needed him removed as he was doing more harm than good. Such theories are naturally highly questionable and rather seem to be face-saving gestures over an obvious failure to keep an ally in power. Private Communication to Author, Ankara, 1995.

331 Tadeusz Swietochowski, ”The Spirit of Baku”, in Central Asia Monitor, No.4, (1993).

${ }^{332}$ See Kechichian and Karasik, ”The Crisis in Azerbaijan”, op. cit. [245], pp.64-65.
} 
retaliated by cutting off power supplies to Nakhjivan, claiming non-payment of debts as a reason. ${ }^{333}$

Since then, Iran has been counteracting all Azeri aims to produce and export its oil. One way to do this has been to refuse to cooperate in a planned pipeline route between Baku and the Turkish Mediterranean port of Ceyhan. This route was intended to stretch from Baku into Iran, then follow the Araxes River and enter Nakhjivan and from there to Turkey, where it would reach the Mediterranean. ${ }^{334}$ Such a route was drawn due to the impossibility of involving Armenia in any pipeline project, a route which would have been the most logical one geographically. Iranian officials clearly stated that if a pipeline went through Iran, it would go to the Persian Gulf and not to Turkey; this solution would give Iran more royalties and control over the outlet of Azeri oiland hence important leverage on Baku. Furthermore, a route through Georgia, which is being investigated currently, is a large deviation and not necessarily a safe route either, given the instability of Georgia (see chapter 4). ${ }^{335}$ Hence in this way Iran actively managed to disturb Azeri hopes of exporting its oil without giving Russia a monopoly over transporting it.

As the exclusion of Iran from the international oil consortium had been a debacle in bilateral relations, Aliyev felt obliged to do something to save his relations with the Islamic Republic. In late 1995, Azerbaijan offered Iran a 10-percent share in the extraction from another oilfield, ShahDeniz, an offer Iran initially rejected as unserious. ${ }^{336}$ In May 1996, however, Iran finally accepted the offer, a decision which may be taken as an indication of the Iranian regime's pragmatism. ${ }^{337}$ Although a certain degree of cooperation exists between the two countries, encouraged by Aliyev, the regime in Tehran still maintains a relatively hostile attitude to its northern neighbor.

\section{The Russo-Iranian Axis Over The Caspian Sea}

Iran has found an ally in Azerbaijan's other foe-Russia. In the post-Soviet era, American attempts to isolate Iran and promote its image as a regional pariah have fallen short of coercing Russia to limit its relations with Iran. ${ }^{338}$ To the contrary, Russia and Iran have improved and expanded trade relations as well as technical cooperation in the nuclear field - a fact which has proven to be a significant disturbance in Russo-American relations. Russian officials, however, have stated that they will not surrender to any pressures regarding their nuclear cooperation with Iran, something which has been noted with satisfaction in Tehran. ${ }^{339}$ Russian and Iranian interests converge in the energy field as well; they both would be largely devoid of oil and gas resources if the Caspian were delimited and divided into territorial waters.

The hydrocarbon resources would almost exclusively fall within the territorial waters of Azerbaijan, Kazakhstan and Turkmenistan. Hence Russia and Iran have both been arguing for the creation of an international regime in the Caspian, where all resources would be jointly exploited by the riparian states. This line of thought is based upon the legal argument that the Caspian is not

\footnotetext{
333 "Iran Cuts Electricity to Nakhichevan" OMRI Daily Digest, 30 May 1995.

${ }^{334}$ BBC Summary of World Broadcasts, 16 March 1993.

${ }^{335}$ Nazlan Ertan, "Baku-Ceyhan: Pipeline or Pipe Dream," Turkish Probe, May 17, 1996, pp.19-20.

336 "Iran Opts Out Of Shakh-Deniz," OMRI Daily Digest, (December 11, 1995).

337 "Iran Finally Agrees to Stake in Shah-Deniz," OMRI Daily Digest, 13 May13, 1996.

${ }^{338}$ OMRI Analytical Brief, 26 June 1996.

339 Mehrdad Mohsenin, "Iran's Relations with Central Asia and the Caucasus," in The Iranian Journal of International Affairs, Fall 1995.
} 
a sea - it has no natural outlet to other seas - but rather, technically speaking, a giant lake, where the laws of the sea do not apply. ${ }^{340}$ By contrast, Azerbaijan and Kazakhstan argue that the Caspian is an enclosed sea, which gives them the right under maritime law to draw national sectors and exploit resources exclusively within them. ${ }^{341}$ Turkmenistan has until recently bowed to Russian pressure and in principle accepted joint exploitation; however, recently the Turkmen government, guided by natural self-interest, seems to be inclined towards joining Azerbaijan and Kazakhstan.

Consequently Russia and Iran have been pressuring Azerbaijan, in particular, but not to the same extent as the two Central Asian republics on the eastern shore of the Caspian, to allow for joint exploitation of oil resources. But for all of Aliyev's intentions to improve relations with both Tehran and Moscow, he has consistently refused to give away an inch of Azerbaijan's sovereignty. Hence Azerbaijan remains the only Transcaucasian republic without Russian troops on its soil; likewise there have been no signs from Baku pointing at any acceptance of the principle of joint exploitation.

In June 1995, Iran and Russia agreed to coordinate their oil and gas policies, in a wider context of improving relations. ${ }^{342}$ Iran is particularly eager to cooperate with Russia as it is under the pressure of U.S. isolation. Both for economic and political reasons, Iran therefore wants to prove that it can stand up against the United States. And given the present character of Russia's domestic politics, anything that proves that Russia is not dependent on the United States is likely to be in the government's interest. Cooperation with Iran, in addition to other factors, also serves this purpose. In the summer of 1995, Iran and Russia agreed to cooperate in offshore drilling and platform construction in the Caspian. ${ }^{343}$ In October of the same year, the two states also elaborated a draft proposal on the legal status of the Caspian, according to which each state would only be granted a 10-mile stretch of territorial waters for mineral extraction. In this context it should be no surprise that most of Azerbaijan's and Turkmenistan's oil and gas resources are much further offshore than this. ${ }^{344}$ Nevertheless, it should be noted that Iran does not insist on joint exploitation to the same degree as Russia does. Rather, Iran has pressed for an agreement among all riparian states in order to lessen instability and conflict. ${ }^{345}$

\section{Iran And The Karabakh War}

As Edmund Herzig has noted, the Karabakh war has been the most direct threat to Iran's national security emanating from the north since the 1940s. ${ }^{346}$ Indeed, as previpous chapters have shown,

\footnotetext{
${ }^{340}$ For an overview of the issues of oil politics in the Caspian, see Elaine Holoboff, "Russia and Oil Politics in the Caspian," in Jane’s Intelligence Review, (February 1996). For a legal overview, see Alex Oude Elferink, "Maritime Boundary Delimitations of the Russian Federation," Journal of Maritime and Coastal Law, No.1, (1997), pp.25-27.

${ }^{341}$ For a legal opinion stressing this principle, see Bruce M. Clagett, "Ownership of Seabed and Subsoil Resources in the Caspian Sea under the Rule of International Law," in Caspian Crossroads, vol. 1 no. 3 , Summer/Fall 1995. See also "Talks in Tehran on Caspian," OMRI Daily Digest, 3 July 1995.

342 "Iran, Russia, and Oil," OMRI Daily Digest, 1 June 1995.

343 "Russia, Iran, and Oil," OMRI Daily Digest, July 18, 1995.

344 "Russia, Iran to Draw Up New Legal Status for Caspian," OMRI Daily Digest, 24 October 1995.

345 See Edmund Herzig, Iran and the Former Soviet South, London: Royal Institute for International Affairs, London, 1995, pp. 28-44.

${ }^{346}$ See Herzig, Iran and the Former Soviet South, op. cit. [345], p. 30.
} 
the conflict has been the worst - and from Iran's perspective the closest-among a plethora of conflicts that have plagued the Caucasus since the late 1980s. Besides ethnic strife, both Azerbaijan and Georgia have been characterized by chronic political instability as well. Arms of all kinds and calibers have proliferated throughout the region, controlled not by the governments of the respective countries but by semiofficial or private paramilitary formations. ${ }^{347}$ Hence the Caucasus as a whole is a source of instability for all regional powers. For Iran, the Nagorno Karabakh conflict has had a special import-ance for a number of reasons. First of all, the fighting, as noted above, has threatened to spill over into Iran at certain points, notably in the fall of 1993. Further, the two states involved in the conflict are both Iran's neighbors, and hence the conflict directly affects Iran's security. But most of all, the conflict has played a role in the larger regional constellations in which Iran has a prominent place.

This led Iran at an early stage - virtually as soon as the two belligerents became independent-to offer its good offices to seek a peaceful solution to the conflict. A first abortive cease-fire was negotiated in Tehran in March 1993 and a "Tehran declaration" was signed in May of the same year. But, as Abdollah Ramezanzadeh states, Iranian mediation was hampered first by the repeated Armenian military conquests of Azerbaijani territory, and second by the advent of the Popular Front government in Baku. The first factor led Iranian radicals to condemn Armenia for using the cease-fires brought about by Iranian diplomacy to provide for rearmament, the second made mediation virtually impossible as President Elçibey refused to accept Iran as a mediator. ${ }^{348}$ To a certain degree, then, Iran has acted to resolve the conflict in a positive manner. But Tehran simultaneously used the Nagorno Karabakh conflict to pursue foreign-policy goals.

Since the conflict erupted into war in 1992, Iran has attempted to exert its influence on Azerbaijan. For the most part, this has meant working against Azerbaijan through support for Armenia. This has, however, not always been the case. When the conflict threatened to spill over into Iran, Tehran actually raised its tone against the Armenians. It made a joint appeal with Turkey to the U.N. Security Council to condemn the Armenian aggression. Hence it seemed as if Tehran was becoming aware of the danger of a collapse in Azerbaijan, which could have important implications for regional security. ${ }^{349}$ Iran at several points made clear that it sought to preserve the existing balance of power in the region. Here again, the Nakhjivan enclave was perceived to be of crucial importance. When Nakhjivan was under threat of an Armenian attack in September 1993, Iranian troops crossed the river Araxes, prompting a strong Russian reaction. Russia made it clear that good relations with Iran are conditional on Iran's acceptance of Russian supremacy in the Caucasus. Nevertheless, Iran's action was enough to intimidate Armenia; the Armenian foreign minister assured Tehran that there would be no more attacks on Nakhjivan. ${ }^{350}$

Except for situations where it was absolutely necessary to restore a balance by preventing Armenia from creating chaos in the region, Tehran used the conflict to pressure Baku. This was generally done through different forms of support for Armenia. As stated above, Iran served as a purveyor of electricity and goods to Armenia, which suffered from the Turkish-supported Azeri embargo of the country. Transport was difficult through war-torn Georgia: Russian supplies had

\footnotetext{
347 For a discussion of the issue, see Charles H. Fairbanks, "The Postcommunist Wars”, in Journal of Democracy, October 1995.

${ }^{348}$ See Ramezanzadeh, ”Iran's Role as Mediator in the Nagorno-Karabakh Crisis”, op. cit. [323].

${ }^{349}$ See discussion in Halliday, "Condemned to React," pp. 84-85.

${ }^{350}$ See Ramezanzadeh, ”Iran's Role as Mediator in the Nagorno-Karabakh Crisis”, op. cit. [323].
} 
difficulties reaching their destination, and the pipeline bringing natural gas to Armenia was sabotaged on several occasions. However important trade relations might have been to sustaining the Armenian war effort, Iran's support went beyond these merely commercial relations. Reports have indicated that Iran served at least as a transit route for weapons en route to Armenia; similarly Armenian fighters have allegedly been trained in Iran. ${ }^{351}$ It is not impossible that certain Armenian movements have retained contacts with Iran from the time of the terrorist campaign against Turkey, which had its high tide in the early 1980s. Azeris argue that ASALA (The Armenian Secret Army for the Liberation of Armenia) still exists and is being trained in Iran, and that this organization has been one of the forces influencing the Armenian government of Nagorno Karabakh.

In any case, Azerbaijan found itself quite isolated, both in the region and globally /see chapter 3). With two powerful enemies - Russia and Iran - and only one reliable but cautious friend Turkey - Azerbaijan fared very poorly in the war. By mid-1993, the ill-organized Azeri army was on the verge of disintegration, and the overthrow of President Elçibey took place with significant military involvement.

The inability of the Elçibey government to control the armed forces and conduct a sensible foreign policy must to a great extent be attributed to the president's own inability to distance himself from his private, academic framework and to adopt the role of statesman. However, the government's failure and eventual downfall is equally attributable to the foreign actors working against it. Among these, Russia was doubtless the most active and determined one; nevertheless, Iran played its part. It did so not only by its direct actions, which by themselves would not have had a tremendous impact on Azerbaijan, but simply because its hostility left Azerbaijan nowhere to go: the West was uninterested, and Turkey was unable to help this newly emerging state.

If Iran and Russia counteracted Azerbaijan's interests with significant success in the Karabakh war, they have simultaneously helped to create a very unstable regional situation, with a conflict in deadlock. The overwhelming majority of observers believe that a negotiated solution will not and cannot be reached in Nagorno Karabakh as the situation is today. The option is that, within a few years time, oil-rich Azerbaijan will resort to military means to reassert control over the territory that it believes to be its own by right. ${ }^{352}$ Hence, the present situation is a highly volatile one. An awareness is growing in the region that if further bloodshed is to be avoided, international mediation efforts must effect an agreement in the near future. ${ }^{353}$

In case no permanent agreement is reached, Iran may find that its policy has had potentially dangerous side-effects. First of all, the risk of further conflict in its neighborhood means increased national-security concerns. As is the case with all armed conflicts, it is impossible to know the ultimate scope of the conflict. Many observers have warned that the Nagorno Karabakh war could become a starting point for a larger regional confrontation, which in the worst case would involve Russia, Turkey and Iran. ${ }^{354}$ Of these three, Iran is the most likely to be dragged into the conflict. First, it is the only regional power to border both Armenia and Azerbaijan; second, its sizable Azeri population remains a factor of instability.

\footnotetext{
${ }^{351}$ See Halliday, op. cit. [300], p. 84.

${ }^{352}$ See Svante E. Cornell, "The Unruly Caucasus," in Current History, Vol.96, No.612, October 1997.

353 See Svante E. Cornell, "Peace or War? The Prospects of Conflicts in the Caucasus," in Iranian Journal of International Affairs, Vol.9, No.2, Summer 1997.
} 
For these reasons it seems to be in Tehran's direct interest to help find a solution to the Karabakh conflict. At times, its policy seems to show an awareness of this reality; ${ }^{355}$ however, all too often Iran finds itself involved in the intrigues and power politics of the region, due both to domestic and external factors.

\section{The Tehran-Moscow-Yerevan Triangle}

The increased cooperation between Russia, Iran and Armenia has led to speculation regarding an emerging set of regional alignments, as will be discussed in a later chapter. This has been strengthened by recent Russian complaints of an anti-Russian coalition of former Soviet republics.

Events in recent years tend to show that Armenia and Iran are developing ties in many fields and that their cooperation amounts to more than just the struggle against the common foe, Baku. As early as February 1992, the Armenian foreign minister visited Tehran and discussed the Karabakh conflict and purchases of natural gas, among other agreements on economic and technical cooperation. ${ }^{356}$ After this, open contacts were more rare until Azeri-Iranian relations deteriorated in 1995. In May 1995, less than a month after Iran had been excluded from the Azerbaijani oil consortium, Armenian Prime Minister Bagratyan, on a visit to Tehran, concluded a number of agreements on economic and political cooperation. ${ }^{357}$ Most important, Iran agreed to supply Armenia with natural gas and electricity for a period of 20 years. This agreement is especially interesting, as Iran cut electricity supplies to Nakhjivan only three weeks after the deal, indicating that there was more than just an economic side to the growing relations between Armenia and Iran. ${ }^{358}$ Incidentally, Iran's close cooperation agreements with Russia were concluded only weeks after these developments. Iran simultaneously adopted a harsher tone towards Azerbaijan, warning it not to develop too-close ties with Israel, for example. ${ }^{359}$ Other high-level meetings discussing further bilateral cooperation were held in Yerevan in December 1996 and in Tehran in February 1997. The Iranian leadership also reiterated its readiness to mediate in Karabakh, something Azerbaijan is decidedly against. From an Azeri point of view, it is natural to see these accords and gestures of friendship as a threat to its security and as an attempt to corner Azerbaijan. However, the scope of this emerging triangle does not limit itself to Azerbaijan. One strong reason for the existence of this regional triangle is, as noted earlier, a common wish among these three states to reduce and prevent the increase of Turkey's influence in Central Asia and the Caucasus, which troubles both Iran and Russia. From Yerevan's perspective, Turkey remains perhaps the greatest threat to Armenia's existence.

As has been outlined above, the dissolution of the Soviet Union was an unwelcome surprise for Tehran, presenting totally new security challenges from its northern frontier. Instead of the predictable Soviet military threat, which had proved quite manageable, Iran was faced with a volatile set of ethnic conflicts in its proximity, which it had little ability to influence. To make matters worse, a considerable part of the Iranian population was potentially encompassed by these conflicts, something which in the worst case could prove to be a threat to the very existence of the

\footnotetext{
354 See discussion in Vaserman and Ginat, "National, Territorial, or Religious Conflict?"

355 See Halliday, "Condemned to React"; Herzig, Iran and the Former Soviet South, pp.29-30.

${ }^{356}$ See Herzig, Iran and the Former Soviet South, p.21.

357 "Armenia, Iran Sign Cooperation Agreements," OMRI Daily Digest 10 May 1995.

358 "Iran Cuts Electricity to Nakhichevan," OMRI Daily Digest 30 May 1995.

359 "Iran to Azerbaijan: No Ties to Israel," OMRI Daily Digest 10 August 1995.
} 
Iranian state. Decision makers in Tehran soon concluded that Azerbaijan was the main threat to Iranian security. They therefore immersed themselves in the intrigues and complexities of Caucasian regional politics, in order to prevent the flourishing of the Azerbaijani state. At first sight, this strategy may seem to have been successful. However, a side-effect has been the exacerbation of the conflict over Nagorno Karabakh, which at present poses a medium-term threat not only to Iran's security but to peace and stability in the entire region. Iranian policy towards the Caucasus reveals the difficult geopolitical situation in which the Islamic Republic finds itself. In its difficult quest to find allies in its proximity, Iran cannot help but become involved in extremely risky maneuvers. 


\section{7 \\ The United States: From Neglect to Commitment}

At the dissolution of the Soviet Union, the United States policy toward the successor states of its former adversary was heavily dominated by concern for the future of Russia, and in particular concern for the control over the massive stockpile of nuclear weapons. To the extent the US at this time was interested in the successor states, it focused on states where Soviet nuclear weapons were deployed, such as Ukraine and Kazakhstan. The US helped secure the transfer to Russia of these weapons, preferring to contain the possession of nuclear weapons to one state, i.e. Russia, in line with the policy of horizontal non-proliferation espoused by Washington. At this point, the United States did then not have a clearly formulated policy toward the Caucasus and Central Asia, beyond principal support for the independence of the newly independent states. In general, the US leadership did not realize the existence and extent of potential US interests in what has only later become commonly referred to in the US as 'the Caspian region'. The knowledge of the region, its peoples, problems and dynamics was very poor: except for a limited number of specialized academicians, virtually no one knew the region. This ignorance and lack of initiative permitted partisan politics in the US congress to leave an imprint on American policy in the region which the administration has been unable to shrug off, especially as concerns the Nagorno Karabakh conflict.

Ever since the liberalization of the Soviet Union, however, private US interest had been awakened in the oil of the Caspian sea since roughly 1990. Shortly before the break-up of the union, several oil multinationals established offices in the riparian republics of the Caspian sea; private investment started growing rapidly and by 1995, the oil interests had begun to make a difference in Washington. Still then, however, initial US reactions to the Russian invasion of Chechnia made it clear that the US accepted the Russian notion of the entire Caucasus and Central Asia being a 'Russian sphere of influence'. The US policy has nevertheless changed considerably since then, pointing to an increasing engagement of the region. US policy can be roughly divided into three periods: first, a lack of clear policy and a Russia-centered approach from December 1991 until 1994; secondly, the cautious formulation of a policy, prompted by oil interests, but still respecting Russia's hegemonic policies in the region, from 1994 until 1996; and finally, since 1996-97, an increased realization of US interests and a strategic engagement of the entire region.

\section{1-94: Incoherence and 'Russia-First' Policy}

The initial period of independence of the successor states of the South of the former Soviet Union was a period of relatively weak American interests and the absence of defined policies. Nevertheless, the period has left an undesired imprint on American policy especially toward the Nagorno Karabakh conflict. The US' main concern of the time was the economic reforms in 
Russia. The US paid lip service to reforms in all Newly Independent States (NIS) as they came to be called; however there was, it seems safe to say, no proactive US policy towards the Southern rim of the former USSR. Basic 'working guidelines' were nevertheless established, which stipulated some basic US interests in the NIS. These included recognition of the states as independent and viable entities, support for their transition to market economies and democratic societies, facilitation of their integration into international institutions, and encouragement of regional cooperative arrangements. ${ }^{360}$ Nevertheless, the main US interest of the time- that is besides the large interests in Russia's transition to market economy and democracy—was to limit the spread of nuclear weapons, by convincing Belarus, Kazakhstan and Ukraine to hand their nuclear weapons over to Russia. In one US policy-maker's words, 'a preoccupation with the four "nuclear successor states" prevented the Caucasus and Central Asian states from getting much serious attention until 1994' ${ }^{361}$ Nevertheless, the US administration soon formulated three modest policy goals for the NIS:

First, the US declared its support for the independence of the NIS and vowed to help preventing them from gravitating into the orbit of Russia or, in particular, Iran.

Second, the US vowed to support the establishment of liberal democratic regimes in the NIS, and has partly_but only partly_adjusted its policy according to the progress of the democratization process in these states.

Third, the US supported the export of the Caspian energy resources through a route that would not exclusively depend upon Russia, and that would most importantly not cross Iranian territory. ${ }^{362}$

\section{Proof of Indifference: Section 907a and the Armenian Lobby}

As far as the Caucasus was concerned, the US policy was rather wobbling. The US established working relations with Armenia from the start, mainly because of the demands from the Armenian American lobby and its associates, but also because of a perception that Armenia was the state which was most successful in fostering a democratic political environment. ${ }^{363}$ Looking back at the domestic political situation in the Transcaucasus in the beginning of 1992, there was indeed cause for this assumption. Whereas the regime of Levon Ter-Petrosyan in Armenia was ruling with heavy popular backing, the Soviet Nomenklatura under Mutalibov in Azerbaijan was only reluctantly being unseated in the Spring of 1992. With regard to Azerbaijan, the situation was totally different. Azerbaijan was too busy with the war in Karabakh and internal squabbles to make a concerted lobbying effort in the West. In fact, Azerbaijan was unable to even make the Azeri side of the events in Karabakh reach news desks in the West. By contrast, the Armenian communities in the US and in France were well organized and powerful, and were instrumental in bringing about a perception of Azerbaijan as an aggressor in the conflict, an anti-Azerbaijani stance that has begun to recede only recently. Partly as a result of this, the US recognized

\footnotetext{
360 See Elizabeth Sherwood-Rendall, "US Policy and the Caucasus”, in Contemporary Caucasus Newsletter, Spring 1998.

361 Ibid.

362 See Paul Goble, "From Myths to Maps: American Interests in the Countries of Central Asia and the Caucasus”, in Caspian Crossroads, vol. 3 no. 1, Summer 1997.

363 See Jim Nichol, ”Transcaucasus Newly Independent States: Political Developments and Implications for U.S. Interests”, CRS Issue Brief, 20 December 1996.
} 
Armenia in December 1991, and Azerbaijan only in February 1992, officially because Armenia had adhered to the Helsinki principles earlier.

In mid-1992, the Freedom Support Act, a long-term programme of economic assistance to the former Soviet Union was enacted. It included a section, the by now infamous section 907(a), which prohibits all US assistance to Azerbaijan due to its 'blockade of Armenia'; the Congress implicitly defined Azerbaijan as the aggressor in the conflict and section 907 must be interpreted as a punishment to Azerbaijan for its policy. The act stipulates that "United States assistance may not be given to the Government of Azerbaijan until the President determines, and so reports to the Congress, that the Government of Azerbaijan is taking demonstrable steps to cease all blockades and other offensive uses of force against Armenia and Nagorno Karabakh”. ${ }^{364}$ The act hence ignored the fact that Armenia was the author of an embargo on Nakhjivan, and hence presumably equally guilty as Azerbaijan. Moreover the use of the term Blockade is misleading, as Turkey and Azerbaijan by no means have the capacity to blockade Armenia; the country does have economic links with Georgia and Iran, and as a result the term 'embargo' is a more correct definition of the situation.

Section 907 was enacted mainly as a result of the strong lobbying efforts of the Armenian community in the United States, whose influential position in US politics is well-known, stemming from an impressive level of organization and lobbying skill as well as its importance in strategic states, notably in California where the votes of the Armenian community are thought to have decisive effects on the outcome of major elections, including presidential ones. Given the lack of a clear policy toward the conflict on the part of the state department and the white house, the Armenian Diaspora was successful in hijacking the policy of the United States to the conflict, taking advantage of the early stage of US relations with the Caucasian states: Azerbaijan did not even have an embassy in Washington at the time and was caught unprepared by the enactment of section 907. In the words of Robert Cutler,

United States policy on Karabakh through much of the 1990s until the present was dominated by the extremely well organized and politically well connected Armenian Diaspora. Legislation was passed which penalized both Azerbaijan and Turkey for their bans on trade with Armenia. ${ }^{365}$

Indeed, the Armenian organizations in the US take pride in their success but deplore their inability to curtail US assistance to Turkey. In the words of a leaflet from the Armenian Assembly of America, 'with the help of our friends in Congress, we secured an \$85 million earmark in US assistance for Armenia in 1996...we are currently advocating for an increase to \$95 million in assistance for next year. We achieved our second legislative goal with the passage of the Humanitarian Aid Corridor Act...which prohibits American foreign aid to any country that blocks the delivery of US Humanitarian assistance to a third country, is now the law of the land'. ${ }^{366}$ The consequences of this act for US interests in the Caucasus may not have been clear to US policymakers at the time but were certainly to become so by the mid-1990s. As MacFarlane and Minear quote an American diplomat,

\footnotetext{
${ }^{364}$ Freedom Support Act, Section 907(a), P.L. 102-511, 24 October 1992, effective January 1993.

365 See Robert M. Cutler, “U.S. Interests and 'Cooperative Security’ in Abkhazia and Karabakh: Engagement versus Commitment”, in Mehmet Tütüncü, ed., Caucasus: War and Peace, Haarlem: SOTA, 1998, p. 136.

366 Quoted in Thomas Goltz, A Montana Perspective on International Aid and Ethnic Politics in Azerbaijan, n.p.
} 
We try to preach human rights and discourage governments from following ethnic policies. Then an ethnic lobby imposes something like this that isn't in U.S. national interest. The Ministry of Foreign Affairs [in Baku] beats us over the head with this every time we see them. ${ }^{367}$

Section 907 was enacted at a time when Azerbaijan was heavily on the offensive in Karabakh, in the middle of 1992; at this time it may indeed have been feasible to view Azerbaijan as aggressive and having the upper hand. However the events immediately following this offensive in any case totally changed the picture, with the Armenian side conquering 20\% of Azerbaijan's territory. Nevertheless these changes did not make Congress repeal it; only gradually and slowly have certain exceptions been made to it since 1996.

The result of the act has been a feeling of deceit and humiliation on the popular level In any case, the consequences of the act for Azerbaijan were considerable. Whereas Armenia receives over a hundred million dollars a year in assistance-Armenia is actually the second per capita recipient of US aid in the world after Israel—the US ban on aid to Azerbaijan had considerable negative effects on international humanitarian efforts to relieve the suffering of the refugees in Azerbaijan. Section 907 stipulates that the US can have nothing to do with Azerbaijani governmental institutions. The result has been that in a post-Soviet country like Azerbaijan, where most relief institutions including hospitals are owned by the government, the US is prohibited from assisting relief. The following quotation is illustrative:

The truth of the matter was that there was a very real relief dilemma in getting American aid to its target, even when sent through NGOs and PVOs like the International Rescue Committee and CARE. Because the government of Azerbaijan owned most of the warehouses, clinics and even support vehicles involved in tending to internal refugees, the American organizations were obliged to keep their aid under tarps in the street, lest they violate Section 907 (a) by having anything to do with Azeri officialdom. ${ }^{368}$

The problem, however, does not limit itself to humanitarian aid. In the opinion of Thomas Goltz, the effect of section 907 is 'not about temporarily alleviating misery, but permanently changing society' ${ }^{369}$ The fact of the matter is that the American aid that reaches Azerbaijan reaches only non-Governmental Organizations. By contrast, in other NIS most of the US assistance is spent working with government officials in promoting legal reform and liberal democracy. In Azerbaijan, US governmental organizations such as the National Democratic Institute are prohibited from operating in this manner; the US government cannot even invite an Azerbaijani governmental official to a conference in the US. Much of the aid as a result goes to organizations that are in opposition to the current regime in Azerbaijan. In Goltz' words, some of the US aid goes to

groups interested less in building civil society in conjunction with the government than solely in changing the government and replacing it with themselves ... not only is the Congress of the United States depriving the current government of Azerbaijan of the democracy and pluralism building

\footnotetext{
367 See S. Neil MacFarlane and Larry Minear, Humanitarian Action and Politics: The Case of NagornoKarabakh, Providence, RI: T.J. Watson Institute for International Studies, Occasional Paper no. 25, 1997, p. 99. 
blocks we are supplying to every other post-Soviet society, it is, in effect, promoting revolution in Azerbaijan-and perpetual revolution at that. ${ }^{370}$

Perpetual, because if the current regime falls from power its proponents would suddenly become eligible for aid, whereas previous recipients would now be banned. The implicit result is that the US is de facto perpetually supporting the Azerbaijani opposition, whatever its political aims might be.

Lately, great efforts have been undertaken to amend the section so as to enable humanitarian assistance to refugees in Azerbaijan at the very least, as will be seen below. The state department was from the beginning negative to the bill; in 1992, it was feared that a pro-Armenian tilt in the US would lead to closer relations between Azerbaijan and Iran. The complicated and worsening relations between Azerbaijan and Iran, as has been explained in chapter 9, nevertheless prevented such a development; a potentially disastrous consequence of US policy in the Caucasus was hence avoided. Unlike the Congress, the State department has consistently followed a policy of neutrality in the conflict. As the tide of the war in 1992-93, and the Armenian advances in Azerbaijani territory showed with clarity that the congressional interpretation of the conflict was at best obsolete, the state department's stance in the conflict became harder. In May 1992, a statement stated that 'the quality and character of its [the United States] relationship with Armenia and Azerbaijan will depend on their commitment to CSCE principles, including the peaceful settlement of disputes'. After the Armenian advances of 1993, US officials rejected Armenia's claim that it was not involved in the fighting. At the same time, they noted that any deployment of US troops in Karabakh was out of the question, with reference to sensitivity of the issue to Russia. $^{371}$

In terms of policy towards the conflicts in Georgia, The United States has kept a rather low profile. The domination of Russia in mediation efforts to these conflicts has restricted the United States to play a role merely through the OSCE and the UN. The US has participated in UNOMIG by providing observers. In terms of conflict resolution, the US has been absent from the negotiations and has been unable to influence them. In general, it is clear that the US never took advantage, as Turkey attempted to do, of the temporary Russian withdrawal from the Transcaucasus in 1992. Rather, it seems that the US at the time preferred Russian domination over this unknown and troublesome area, with few US interests, to a volatile situation which had the potential to lead to a confrontation of Russia and Turkey. Implicit in this thinking was the concept, inherited from the cold war period, of spheres of interest. Russia missed no chance to mention that it did not interfere with US policies in Central America, and that consequently the US had no business to disturb Russia in its efforts to restore control over Transcaucasia. The United States leadership, moreover, seem to have accepted this line of thought. It should be mentioned that US caution in its relations with Russia was conditioned mainly by two factors. The first was a perception that Yeltsin was to be supported at every cost, being the symbol of democratization and liberalization of Russia which would prevent the country from slipping into dangerous authoritarianism and xenophobia; the second was that the US had a considerable respect for the military and strategic capabilities of the former Soviet Union: Russia was rightly identified as the direct heir to the Soviet military forces; however it was wrongly believed to

\footnotetext{
${ }^{370}$ Ibid.
} 
possess the conventional military capabilities as the Soviet Union. Nevertheless, the United States initially perceived Russia as 'almost' an equal in military and strategic terms and acted thereafter. This was nevertheless going to change.

\section{4-96: The Formulation of a Policy}

While the state department was busy dealing with Yeltsin and had various US and international bodies distribute credits to Russia to prop up the Yeltsin regime's professed economic transition, the private sector had discovered the Caspian oil resources. Indeed, the importance of the Caspian and the Caucasus was discovered in Houston, not in Washington. As mentioned, the American oil multinationals were present in the region early on and made sure they were not left out of the emerging consortia in Kazakhstan and Azerbaijan; to the contrary US firms took a leading role; in Kazakhstan, Chevron was the primary actor in the development of the Tengiz oil fields, contracting the deal already in late 1993; in the Azerbaijani 'deal of the century' of 1994, American companies held $40 \%$ of the stakes. ${ }^{372}$ These private economic interests eventually led to an increasing governmental interest in the region.

\section{The Creation of an 'Azerbaijan Lobby': Heydar Aliyev's Masterpiece}

The interesting fact, in this context, was that the interests of the oil companies in many respects equaled those of Azerbaijan. First of all, Azerbaijan's oil resources are predominantly offshore whereas the Kazakhstani oil field are mainly onshore; this entails that Azerbaijan is distinctively more vulnerable than Kazakhstan — of for that matter Turkmenistan-to the legal status of the Caspian sea. This in turn meant that the oil companies had a vested interest in the sectoral delimitation of the Caspian Sea, and hence in resisting Russian and Iranian claims to a 'condominium', where these states would do their utmost to prevent American companies from participating. This fact was also part of the design of Heydar Aliyev's foreign policy. Starting with the 'contract of the century' and developing with the over a dozen contracts that have been signed between Azerbaijan and oil multinationals, the consistent policy of Aliyev has been to try to attract as many foreign powers as possible into the politics of oil, thereby bringing about a vested interest in these countries in supporting Aliyev's regime-and, by extension, displaying a more positive attitude toward Azerbaijan and its position in the Nagorno Karabakh conflict. Aliyev had a consistent hierarchy of priorities given to different states. The first priority was the United States; only after came Russia, Turkey, Iran, Europe, Middle Eastern State and Japan. ${ }^{373}$ Aliyev's strategy was clear: to attract a high level of private American interests in Azerbaijan, confident that this would increase the importance of the country in US foreign policy. In this strategy, Aliyev clearly counted on the influence of 'Texas Oil' in the domestic US politics, to counterbalance the Armenian lobby. Texas oil interests had a clear interest in attracting US

\footnotetext{
371 See Carol Migdalowitz, Armenia-Azerbaijan Conflict, Congressional Research Service, n.p., section on US policy.

${ }^{372}$ However the BP-Amoco merger entailed that Amoco's share of over $17 \%$ is now mainly controlled by British interests. For an overview of business interests in the Caspian, see Julia Nanay, ”The U.S. in the Caspian: The Divergence of Political and Commercial Interests”, in Middle East Policy, vol. 6 no. 2, October 1998.

373 Terry Adams's keynote speech to the conference on 'Energy and Security in the Caucasus and Central Asia' sponsored by the Institute for EastWest Studies and the Swedish Institute for International Affairs, Stockholm 34 September 1998, illustrated President Aliyev's policies in detail.
} 
attention to Azerbaijan for several reasons. First of all, the Caucasus and indeed Azerbaijan remained unstable areas, and there was at all times a risk involved in the multi-million dollar investments the oil companies undertook in the country. The fate of oil companies was increasingly tied to the fate of Aliyev's regime, as certain Azerbaijani opposition figures claimed they would renegotiate the contracts should they come to power. And, in turn, the stability of the Aliyev regime depended partly on eliminating threats to it from abroad-especially from circles in Russia; and secondly on the resolution of the Karabakh conflict. The absence of a resolution to the conflict, and the predominance of the Armenian position internationally, could seriously threaten Aliyev's regime. Hence it was in the interest of the oil multinationals to engage the US government in Azerbaijan, thereby first of all increasing the security of the Aliyev regime by increasing US stakes in the country, which in turn would lead to the US administration expressing its support for Aliyev. Moreover, involving the US in Azerbaijan entailed to support the Azerbaijani attempts at removing section 907 from US legislation. Removal of section 907 would make the oil companies eligible for government-backed loans and financial assistance; more importantly, however, the US oil companies got clear signals from Baku that European or Middle Eastern oil firms might be favored over American ones if the ban persists. Even without such signals, such companies would have a comparative advantage if their bid for a piece of the oil riches is coupled with the support of their respective governments. The oil companies hence began using their powerful lobbying structures in Washington to further Azerbaijan's interests, and thereby their own interests in the region. Meanwhile, several former high decision-makers in the United States had begun involving themselves with the Caspian oil issues, in particular with Azerbaijan, as Baku's role as the hub of the Caspian oil industry became increasingly clear. Indeed, since 1996 and in some cases even earlier, Baku was the place of convergence of the paths of the above-noted Zbigniew Brzezinski; his fellow former National Security Advisor Brent Scowcroft, former White House chief of staff James Sununu, former Defense Secretary Richard Cheney, and the former Treasury secretary Lloyd Bentsen, to name only the most well-known figures. ${ }^{374}$ The increasing pressure resulted in a noted editorial in the Washington Post of 1 August 1996, under the headline 'Armenia Lobby'. In surprisingly harsh wordings, the editorial condemned the predominance of the Armenian lobby in Congress:

\begin{abstract}
The United States continues to intervene mischievously in the appalling conflict between Armenia and Azerbaijan. Its particular contribution is to increase the misery of a million Azeri refugees, and in that way to draw out hopes for a settlement. ... In short, the United States is punishing the loser and comforting the conqueror, occupier and evident winner of the war. ... Is there an American interest in denying normal humanitarian aid to a small country that-though not especially democratic-is reaching to the West and is critical to its region's political stability and economic promise? The American Armenian community and its supporters, led by former senator Robert Dole, make no such showing. Rather, what is on display is ethnic political power. ${ }^{375}$
\end{abstract}

Caspian oil was appealing to the United States for several reasons. From a strategic point of view, Caspian oil had the potential of lessening western energy dependence on the Persian Gulf, which has been a consistent liability in US energy policy. This would naturally entail that Caspian oil must be exported westwards-lest it again would end up in the Persian Gulf through a pipeline through Iran, thereby increasing further the importance of the Gulf. This was the first reason why

\footnotetext{
374 See David B. Ottaway and Dan Morgan, ”Former U.S. Aides Seek Caspian Gusher”, in The Washington Post, 6 July 1997, p. 1.

375 Editorial in the Washington Post, 1 August 1996, p. A22.
} 
the US later became an advocate of the Turkish pipeline option. The second reason, naturally, was the remaining policy of dual containment, with an explicit urge to prevent Iranian participation in Caspian oil extraction, and especially an Iranian pipeline which would give the country political leverage and influence in the Caucasus. As a result, Aliyev in 1994 took the dangerous step of excluding Iran from the 'contract of the century' despite the fact that it had been promised a five percent stake. This was done, not surprisingly, after demands from Washington. Nevertheless certain instances prove the emergence of an American interests in the Caucasus. As Dimitri Danilov notes,

\begin{abstract}
the statement by the Russian foreign ministry on the non-recognition of the oil contract of 20 September changed the situation again, leading the US on the one hand to oppose Russia's having too strong a voice in Transcaucasia and, on the other, to strengthen its own role. At a meeting with Boris Yeltsin on 27-28 September [1994] in Washington, Bill Clinton called on him to disavow the Russian statement, while Yeltsin failed to make progress on the question of securing the recognition of Russia's role as the main peacekeeper in the Karabakh conflict. Significantly, the US simultaneously demonstrated its intention of playing a more active role: a meeting of the presidents of Armenia and Azerbaijan with US mediation (where the US was represented by Madeleine Albright) was organized in New York on 27 September. ${ }^{376}$
\end{abstract}

\title{
The Watershed: The War in Chechnia
}

At the time the Russian army entered Chechnia in late 1994, the cautious character of American policy was clear. Secretary of State Warren Christopher even made a misplaced comment that compared the intervention with the US civil war; ${ }^{377}$ in another occasion he stated that Yeltsin had probably done what he had to do to prevent Chechnia's secession. An other state department statement noted that the Chechen crisis would not harm the US-Russian 'strategic partnership'. However, the criticism of this policy line became tougher with the revelations of massive Human Rights Violations in Chechnia. The republican majority in the Congress saw the opportunity to criticize the Clinton Administration's Russocentric policy, in line with the republican line of strengthening support for the NIS vis-à-vis Russia. Critics of US policy towards Russia also increased their voices gradually; Zbigniew Brzezinski, a former National Security Advisor under the Carter administration, even noted that the US administration had 'joined the oppressors in actually vilifying the victims and justifying the oppression. ${ }^{378}$ Official US criticism of Russia increased but remained meager compared even to Western European states, not to speak of Eastern European ones: It only stretched as far as claiming that Russia had not fulfilled its commitments under the Helsinki Final Act, a gross underestimation. ${ }^{379}$

Nevertheless, the US policy underwent a drastic change with the Chechen war, although this could not be noticed first-hand from the official statements, because the change was in the realm of the perception of Russia in Washington. Indeed, US military and civilian officials were rapidly

\footnotetext{
376 See Dimitri Danilov, ”Russia’s Search for an International Mandate in Transcaucasia”, in Bruno Coppetiers, ed., Contested Borders in the Caucasus, Brussels: VUBPress, 1996, pp. 148-149.

377 See Svante E. Cornell, "International Reactions to Massive Human Rights Violations: The Case of Chechnia”, in Europe-Asia Studies, vol. 51 no. 1, 1999, p. 91.

${ }^{378}$ See Taras Kuzio, ”International Reaction to the Chechen Crisis”, in Central Asian Survey, vol. 16 no. 1, 1996, p. 103.

${ }^{379}$ For discussions on international reactions see Kuzio, ”International Reaction to the Chechen Crisis”, op. cit. [378], and Cornell, ”International Reactions to Massive Human Rights Violations: The Case of Chechnia”, op. cit. [377].
} 
exposed to the dismal status of the Russian army; reports that were reaching the wet showed that this was definitively not—at least in conventional military terms - the 'big red machine' which was at parity with or at least comparable to the military capability of the United States. The watershed, then was August 1996, when the Chechen fighters recaptured Grozny despite a significant numerical inferiority. (see chapter 5) It seems in retrospect as if the US leadership gradually lost all respect it had had for Russia as a great power with which it desperately needed to keep good relations. Moreover, August also meant that Boris Yeltsin was re-elected to the Russian presidency, and that as a result the US no longer needed to support his policies for fear of an anti-Western reaction in the Russian elections - which was perceived as possibly leading to the election of the Communist candidate Zyuganov. The changes in US attitudes did not become obvious at once; however it did so in early 1997, with the substantial reshuffle of president Clinton's cabinet that accompanied his own re-election only months after Yeltsin's.

The importance of the Chechen war in making public the inability of Russia to militarily assert its influence, and in general its dismal handling of the crisis, had two consequences. The first was that Russia could not be expected to take rational and predictable actions with regard to problems on its periphery; this entailed that there is still a Russian threat: Russia is basically able to create a lot of trouble for its neighbours but unable to mount a credible military offensive capacityleaving out the nuclear option. The second consequence, then, is the retreat of Russian influence. In the words of Stephen Blank,

Russian military and economic power is visibly retreating as Moscow's capability to control its outlying provinces and neighbouring republics declines. ... This retreat of Russian power is another structural factor that plays an important role in shaping regional outcomes because it affects both local security calculus and the actions of the major foreign players. ... Due to the failure of coercive diplomacy and the shocking defeat in Chechnya, Russia is already effectively leaving the area as troop reductions, withdrawals and the accords with Groznyy and Baku all show. ${ }^{380}$

\section{7 and After: Strategic Engagement of the Caspian Region}

The most important change in the cabinet of the second Clinton Administration was from the viewpoint of the Caspian the 'retirement' of Warren Christopher as secretary of state, and his replacement with the more assertive Madeleine Albright. Soon enough, the increased attention the Caspian region had begun to enjoy in the West translated into a policy change. In 27 March 1997, that is barely two months after the beginning of the second Clinton administration, National Security Advisor Sandy Berger singled out China, Turkey and the Caucasus as areas of special emphasis and stressed Washington's intent to step up its involvement in the Caucasus and Central Asia. ${ }^{381}$ In July of the same year deputy Secretary of State Strobe Talbott said that Transcaucasia and Central Asia make up 'a strategically vital region' for the US, and that what happens there 'matters profoundly' to the US. ${ }^{382}$ The causes of this policy change are difficult to assess. Most analysts seem to adhere to the simplistic explanation that oil brings American interests. And indeed, oil is important. The United States presently imports 52\% of its oil consumption, whereas in 1983 the figure was only 31\%. And the increased dependence on imported oil has in practice meant an increased dependence of Persian Gulf oil, a situation which is distinctively worrisome

\footnotetext{
${ }^{380}$ See Stephen Blank, ”Instability in the Caucasus: Old trends, New Traits”, in Jane's Intelligence Review, April 1998, p. 16.

381 See discussion in James Mac Dougall, ”A New Stage in U.S.- Caspian Sea Basin Relations”, in Central Asia (Luleo) no. 5, 1997.

${ }^{382}$ K.P. Foley, ”Turkmenistan: Niyazov Makes First Official Visit To US”, RFE/RL Report, 20 April 1998.
} 
for US policy-makers engulfed in a dual containment of Iran and Iraq, the two most powerful states in the Gulf. Small wonder, then, that the US leadership greeted with pleasure the suggestion that the Caspian Sea might hold up to 200 billion barrels of oil. The Caspian was believed, and still so by some analysts, to have a potential to rank third in the world after the Gulf and Russia in terms of oil reserves. With Azerbaijan being not only a major producer of these hydrocarbon resources, but also a possible transit route westwards - the preferred direction for the West-for Kazakhstani and Turkmenistani resources through a Trans-Caspian pipeline, the reasons to effect a rapprochement with the regime in Baku seem clear enough. The Caspian would then be a major source of diversification of oil imports for the foreseeable future; and hence be of significant importance to US national security.

\title{
An Increasingly Assertive Policy
}

The result has been that the US administration is pressuring Congress in a much more assertive way than before to repel section 907 of the Freedom Support Act. For example, Madeleine Albright stated in a letter to Bob Livingston, Chairman of the House of Representatives Appropriations Committee, of September 1998 that 'Section 907 damages U.S. national interests by undermining the Administration’s neutrality in promoting a settlement in Nagorno Karabakh, ability to encourage economic and broad legal reforms in Azerbaijan, and efforts to advance an East-West energy transport corridor'. In an even more clear manner, Albright's advisor Stephen Sestanovich illustrated the State Department's view of section 907 as follows:

\begin{abstract}
As Secretary Albright and Deputy Secretary Talbott have testified before Congress, Section 907 remains a serious obstacle to our diplomacy in Azerbaijan. ... It is understandable that 907 is seen by some to raise doubts about U.S. neutrality vis-à-vis Azerbaijan and Armenia in negotiations on Nagorno-Karabakh. We do not believe that 907 has advanced the objective its supporters intended when it was passed in 1992. To be blunt, it has done nothing to bring us closer to a lasting peace to the Nagorno-Karabakh conflict. Politically, Section 907 and related provisions are an impediment to our making progress on Nagorno-Karabakh, to our ability to work effectively with Azerbaijan on the east-west Eurasian transport corridor, to advancing in Azerbaijan the same reforms we have supported in other NIS countries, and to the ability of U.S. firms to do business in Azerbaijan. The Azerbaijani Government is strongly pro-U.S. It is being helpful to us on Caspian energy questions, on nonproliferation, on Iranian terrorism-and on Nagorno-Karabakh. Section 907 has limited and will continue to limit the expansion of U.S.-Azerbaijani relations- to no useful purpose. ${ }^{383}$
\end{abstract}

In fact, 1997 meant that two tendencies became increasingly clear: first, that the oil lobby in the US became a counterbalance to the Armenian lobby in the Congress on issues related to the Caucasus policy of the US-in some instances, there were even signs that the Jewish lobby, now supporting Turkey against the Greek and Armenian lobbies due to the Turkish-Israeli cooperation, lent support to Azerbaijan, albeit on a small scale. These developments prompted worry among the Armenian community, a proponent of which noted that 'this year the major American oil companies are working ... to further the Azeri government's political objectives, and are clearly coordinating very closely with the government of Azerbaijan'. ${ }^{384}$ In a situation where the US

\footnotetext{
383 Stephen Sestanovich, Ambassador-at-Large and Special Adviser to the Secretary of State for the New Independent States, Statement before the House International Relations Committee,Washington DC, 30 April 1998.

384 See quotation in Ottaway and Morgan, ”Former U.S. Aides Seek Caspian Gusher”.
} 
government's policy towards the Caspian region is already formulated in a dialogue with the oil companies, it seems as if Baku's position is indeed gaining strength in Washington.

A corollary of increased US interest in the region has been conflict resolution. The Clinton Administration has acted more resolutely to take a more assertive and active role in the negotiation efforts in the Caucasian conflicts. This has partly led to an attempt to pay more importance to Abkhazia, but has mainly been focused on a more active role in the Minsk Group negotiating over Nagorno-Karabakh. In January 1997, the US became the third co-chairman of the Minsk Group. The circumstances under which this happened deserve to be dwelled upon briefly. Russia was the permanent co-chairman of the time, whereas other OSCE countries held a rotating co-chairmanship, which was held by Finland. As France showed its interest in replacing Finland and was greeted warmly by other OSCE countries which were mostly interested in not getting involved in this seemingly intractable conflict, Azerbaijan objected and stated that it did not consider France an impartial mediator (due to the influence of the Armenian lobby in France) and instead desired the US to be assigned to the post.

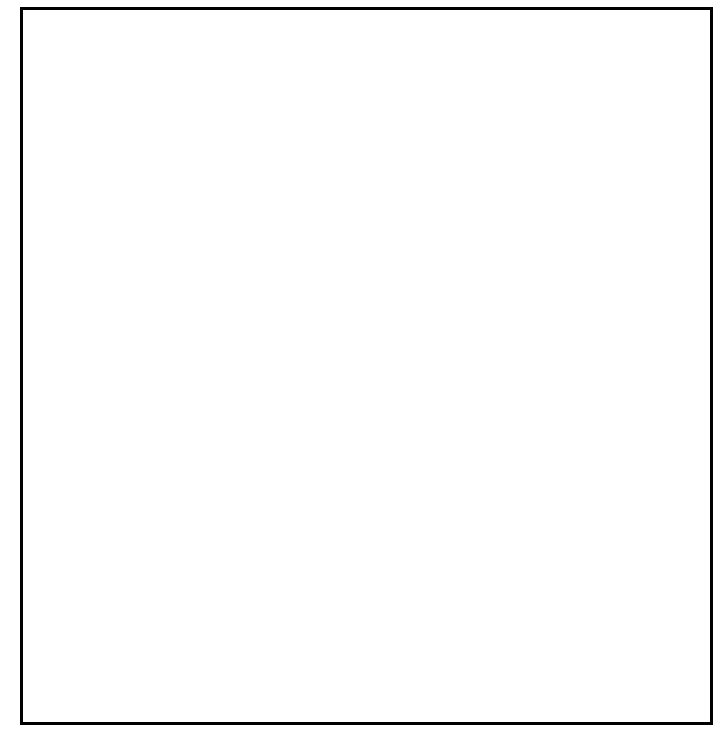

Figure Error! Unknown switch argument.: Aliyev and Clinton in July 1997
In a face-saving gesture for everyone, the OSCE decided to step up the Minsk Group to a 'Troika' of Russian, French and American CoChairmen. What was significant was that Azerbaijan's perception of US policy had grown such a confidence that Baku actually demanded Washington's participation in the Minsk Group, something that had hardly been imaginable a few years earlier. Azerbaijan obviously deemed that the Armenian lobby in Congress had all but lost its influence over American policy-making on the conflict. The picture was completed with the official visit of Heydar Aliyev to Washington in July 1997, where a number of private cooperation deals were signed. The visit was soon capitalized upon by the Azerbaijani leadership, especially for domestic purposes; it was presented to the Azerbaijani public as a major foreign policy achievement and was broadcast in smallest detail over and over again on national television. Meanwhile, US officials now began putting increasing pressure upon the Armenian government to compromise on the issue of Karabakh's status. In the words of a US diplomat in Yerevan, 'we now put more pressure on the Armenian side than on the Azeris'. ${ }^{385}$ This, of course, was especially the case after the announcement of the step-by-step plan of the OSCE and the subsequent internal debate in Armenia leading to president Ter-Petrosyan's resignation. (see chapter 3) Armenia now feels, with some justification, that the US is exerting an unwarranted amount of pressure on Armenia to compromise for the simple reason that a solution to the conflict would greatly improve the possibilities for the speedy creation of an east-west transportation corridor, in particular with relation to the export of oil westwards through Turkey. The

\footnotetext{
${ }^{385}$ Interview with a US diplomat in Yerevan in October 1998.
} 
surprisingly harsh words of Peter Tomsen at his closing press conference after three years as US ambassador in Yerevan are illustrative of this tendency:

\begin{abstract}
No country recognizes Karabakh's independence. This is U.S. policy and it is the policy of the OSCE. In other words all of these countries [53 out of 54] recognize the territorial integrity of Azerbaijan, and that Karabakh is within the borders of Azerbaijan. Unless you want an unending future of conflict, tension and periodic wars, we urge that you talk to Azerbaijanis and the three sides reach a 'modus vivendi.' No side can win 100 percent. As I said, there is not even a dialogue, much less any progress toward an agreement [these days]. We believe that Armenia cannot realize sustained, robust economic growth unless there is a solution to the Karabakh dispute. As I leave Armenia, I urge you not to become complacent and think that everything is $\mathrm{OK}-\mathrm{it}$ is not $\mathrm{OK}$. The seeds of war are there. You should try to remove them through political negotiations...If there is no political negotiation, inevitably military tensions and military buildups go forward, eventually leading to another conflict and war. 386
\end{abstract}

The stated goals of American foreign policy in the Caucasus and Central Asia also altered in this period. By early 1998, these were officially summarized as containing four elements:

- Strengthening modern political and economic institutions and advancing market economy;

- Conflict resolution;

- Energy development and the creation of an east-west energy transport corridor;

- Security cooperation. ${ }^{387}$

Compared with the modest policy goals of the first period of the independence of these states, some obvious changes are due to the evolution of the region. For example, the first principle is very much the continuation of the support for their independence-something which was by no means certain in 1991, but has been achieved since then - and the aim of inciting these states to adopt a liberal market economy. Interestingly, the principle of democratic rule is not included in the stated aims; it can be assumed as being encompassed in the term 'modern' preceding political and economic institutions. Nevertheless the apparent decline of the importance accorded to the form of rule can be understood as suggesting an increased strategic interest, whereby the strategic interests of the US have superseded the more moral aspects of the earlier policy. For example, Turkmenistan's president Saparmurad Niyazov was invited to Washington in April 1998 despite heavy criticism of Turkmenistan's lack of regime transition and Human Rights abuses, coming from the US media, Human Rights organizations, and the state department itself..$^{388}$

The pledge to help the oil-producing states export their resources westwards has been strengthened, and elaborated into a wider project, the East-West Transport Corridor, TRACECA. Hence the US policy has gone beyond oil and a larger vision of an entirely new communications system across the Caucasus and the Caspian Sea to Central Asia has taken form, elaborating on the earlier pledge to support regional cooperation. However, the two other elements, conflict resolution and especially security cooperation, are totally new and both would have been unthinkable in 1992-94. An active US role in conflict resolution in the Caucasian conflicts, but

\footnotetext{
${ }^{386}$ Statement by Ambassador Peter Tomsen, at a press conference in Yerevan on 20 August 1998.

387 Stephen Sestanovich, (Ambassador-at-Large and Special Adviser to the Secretary of State for the New Independent States) "U.S. Policy Toward the Caucasus and Central Asia”, Statement before the House International Relations Committee Washington, DC, 30 April 1998.

${ }^{388}$ Michael Lelyveld, ”Turkmenistan: Did Costs Outweigh Benefits of President's U.S. Visit?”, RFE/RL Report, 5 May 1998.
} 
also in Tajikistan, would have been seen as a grave encroachment on Russian primacy in the NIS and would therefore have gone against the then over-reaching principle of deference to and support for Russia. But the really novel principle is security cooperation. The US has been actively promoting the establishment of a Central Asian Peacekeeping Battalion, known as CENTRASBAT. The US held exercises in Kazakhstan and Uzbekistan involving over 500 US troops; while the US government was quick to announce that it did not mean to send any 'signals' to any state in the region, the military element in US relations with states of the former Soviet Union was not greeted by Russia. The statements of the US leadership included talk of 'independent, sovereign states that are able to defend themselves'. ${ }^{389}$ According to US Atlantic Command officials, America had three broad objectives for the exercise: Promoting regional cooperation through combined military activity; reinforcing the sovereignty of the three Central Asian nations that make up the battalion; and encouraging the development of capabilities by these countries to meet the standards of both recent international peacekeeping efforts and civilian-controlled professional militaries in emerging democracies. ${ }^{390}$ Nevertheless, the repercussions of this event go far beyond the stated aims, whether these repercussions are intended or not. Most importantly, the states of the region clearly interpret this move as a signal that the US is now seriously aiming at establishing its strategic influence in the region, and consequently that it does no longer accept the NIS as a Russian sphere of influence. ${ }^{391}$ The difficulty lies in pursuing this policy while simultaneously working for the integration of Russia into the global economic and political system; in other words, the US leadership knows that it will attract Russia's wrath by 'intruding' into its 'near abroad'; however presently-and this is the major difference- the US deems increasing its influence in the Caspian region more important than safeguarding its 'partnership' with Russia. Indeed, any hopes to convince Russia that the US is merely aiming at creating a win-win situation for everyone, which would also be in Russia's interests, are naive. In the words of Stephen Blank, 'Given regional conditions and mentalities, not to mention actual US policy, [US insistence on aiming to create a win-win situation] seems misplaced, if not naive. US officials concede that Russia finds it difficult to accept this notion ... win-win ideas generally remain foreign to their cognitive universe and contradict the prevailing zero-sum Realpolitik Russian and Trans-Caspian mentality'. ${ }^{392}$ The clear fact is that the US is now trying to prevent Russia from regaining its hegemony over Central Asia and the Caucasus; as long as Russia considers it to be in its national interest to maintain its southern periphery as its own exclusive sphere of influence, the policies of Russia and the United States are bound to clash. In particular, Russian analysts are highly suspicious of American military agreements with the NIS. In a recent article, the influential analyst Sergo Mikoyan noted that

\footnotetext{
Washington's goal seems to be to weaken Russian influence in the area or to force Russia out altogether. Such intentions can be seen in different actions and diplomatic activities. Most significant are the military agreements signed by the US with Ukraine (July 1993), Azerbaijan (July 1997), Kazakstan (November 1997) and Georgia (March 1998). Since all these countries participate in NATO's Partnership for Peace (PFP) programme, it is not clear why these special bilateral agreements were also necessary. The education of local military personnel in US military academies,

389 Julie Moffett, "Central Asia: Joint Military Exercise Deemed a Success”, RFE/RL Report, 26 September 1997, quoting Deputy Assistant Defense Secretary Catherine Kelleher.

${ }^{390}$ Julie Moffett, ”Central Asia: U.S. to Participate in Joint Military Exercise”, RFE/RL Report, 29 August 1997.

${ }^{391}$ Paul Goble, ”Central Asia: Analysis from Washington-a Jump Too Far?”, in RFE/RL Report, 2 September 1997.

${ }^{392}$ Blank, ”Instability in the Caucasus”, op. cit. [380], p. 17.
} 
supplying weapons and sending instructors can only be interpreted in Moscow as actions that are designed to undermine the newly independent states’ relationships with Russia. ${ }^{393}$

The increasing frequency at which the US and Turkey hold joint military exercises with NIS gives further fuel to the Russian fire. Mikoyan cites sources showing a dramatic increase in US/NATO military presence in the Black sea. In 1991, 3-4 NATO exercises were held there whereas the figure for 1997 was $10-15 .{ }^{394}$ In early 1999, the Armenian-Russian military alliance, examined in chapter 9, led to a rather sensational statement by Azerbaijani veteran presidential advisor Vafa Gulizade: Unless Russian military bases are withdrawn from Georgia and Armenia, Azerbaijan would be willing to host a 'US, NATO, or Turkish military base in the Apsheron peninsula' of Azerbaijan, which 'would serve U.S. strategic interests in the Caucasus' ${ }^{395}$ Although the statement was later stated to be a personal opinion, it is beyond doubt that any statement of this caliber must have been made with the knowledge of President Aliyev. Mr. Gulizade is known for his careful approach; although Azerbaijan presumably knows the lack of likelihood of the realization of such a project, the statement was intended to send certain signals to Russia and Armenia regarding their increasingly close security cooperation. The message, hence, was that Azerbaijan could make use of its rapidly developing relations with the US as a counterbalance to the Russo-Armenian alliance, which Stephen Blank calls 'extremely close to a an outright military alliance against Azerbaijan'. ${ }^{396}$ In this context, Georgia’s increasingly close ties to NATO and joint exercises with Turkey deserve mention; furthermore the relatively overt Georgian political aim of joining NATO within a period of five to ten years is illustrative of the movement of certain post-Soviet states to brake away from Russia's sphere of influence. In the words of Annette Bohr, 'Uzbekistan has joined the ranks of Israel and Turkey in relying on the United States as the chief guarantor of its independent foreign policy and international security' ${ }^{397}$ Judging from current developments and trends, this group of states may be joined by Georgia and Azerbaijan as quickly as the strategic environment in the Caucasus possible allows it. The tendency is clear and the attempts by Russia to sustain its influence in the Caucasus is receding with 'conventional' means, that is everything except subversive actions.

\section{Reasons for the Policy Switch}

Behind this apparent switch in US policy, of course, lies the loss of respect for Russia and its capabilities in the Caucasus. Since August 1996, the US policy-makers seem to have increasingly adhered to a perception of Russia as a receding power; the condition of its military, the health of its president, and the situation of the Russian economy all point to this and strengthen the American feeling of superiority. While searching the reasons for the switch in US policy towards the Caucasus, the oil factor is as has been noted often stated to be the primary reason.

\footnotetext{
393 See Sergo A. Mikoyan, ”Russia, the US, and Regional Conflict in Eurasia”, in Survival, vol. 40 no. 3 , Autumn 1998, pp. 11-26, here at p. 119.

${ }^{394}$ Mikoyan, ”Russia, the US, and Regional Conflict”, op. cit. [393], quoting Yevgeni Shevelev, ”Chernomorski Flot Neobchodim Rossii”, in Nezavisimoye Voyennoye Obozrenia, 22-28 August 1997.

395 See Asya Hadjizade, ”Will an American Military Base be Deployed in Apsheron?”, in Nezavismaya Gazeta, 20 January 1999, p. 2; Armenpress, 18 January 1999; RFE/RL Newsline, 19 January 1999.

${ }^{396}$ Blank, ”Instability in the Caucasus”, op. cit. [380], p. 16.

${ }^{397}$ See Annette Bohr, Uzbekistan: Politics and Foreign Policy, London: RIIA, 1998, p. 64.
} 
However there is indeed, as Dilip Hiro puts it, something fishy about the monocausal 'oil' explanation. First of all, of course, most experts agree that the Caspian is by no means comparable in terms of oil reserves to the Middle East; it is rather comparable to one or at best two North Seas; oil companies seem to refer to the projections of 200 billion barrels as mere wishful thinking. ${ }^{398}$ Terry Adams, a former president of the Azerbaijan International Operating Company, notes that

There has been much speculation in the media that Azerbaijan and the Caspian will be like another Middle East. However, a more accurate comparison would be the North Sea. Coincidentally, Azerbaijan's proven reserves of 17.5 billion barrels is exactly equivalent to that of the North Sea's. But from the known database, geologically speaking, at least, the equivalent of two more North Seas may be found in the South Caspian. ${ }^{399}$

If the 200 billion barrels are wishful thinking, they are indeed very effective wishful thinking since the second Clinton administration seems to have swallowed these predictions without doubt. Indeed, the title of an article by Hiro is called for: 'Why is the US Inflating Caspian oil Reserves? ${ }^{400}$ The fact is that the statements of the State Department constantly refer to the highest possible expectations of oil resources, considered improbable by the industry. To the question as to why this is the case, two answers are possible: the first is that Washington really believes in these figures; the second is that Washington is using the oil issue as an ostensible reason for its involvement, hiding some larger scheme which it desires not to make public.

One of the most ardent advocates of US interests in the Caucasus, Senator Sam Brownback, recently presented his view of US interests in the Caspian region, and the ways to achieve them, elements that are helpful in understanding the US policy there. ${ }^{401}$ Brownback outlines five areas of interest: First, the Central Asian and Caucasian states are a bulwark against the spread of Iranian 'anti-Western extremism'; secondly, the oil potential of the region 'could exceed' four trillion dollars in value, and could reduce US dependence on Persian Gulf oil; Thirdly, the development of strong market economies in the vicinity of China and Russia could influence these states in their economic transition; fourth, the regional states are a bulwark against the possible proliferation southward from Russia of weapons of mass destruction; finally, the region presents a 'historic opportunity to spread freedom and democratic ideals in Asia'. ${ }^{402}$ Such points nevertheless do not explain the place of the 'Caspian region' in US global policy. Is the central factor of the increasing US interest really oil? And if so, how can the lack of serious and objective analysis of the actual oil reserves in the Caspian be explained? According to the BP statistical review of world energy, the proven oil reserves of Azerbaijan and Kazakhstan amount to 15 billion barrels, of a world total of just over a thousand billion barrels. Now the actual reserves are certainly over 15 billion barrels, given the fact that the Caspian region has not been satisfactorily

\footnotetext{
${ }^{398}$ Eg. Presentations by Terry Adams (Monument Oil) and Willy Olsen (Statoil) at the conference on 'Energy and Security in the Caucasus and Central Asia' sponsored by the Institute for EastWest Studies and the Swedish Institute for International Affairs, Stockholm 3-4 September 1998.

399 Terry Adams, then President of Azerbaijan International Operating Company (AIOC), at the AmCham Luncheon in Baku on June 26, 1997, quoted in Azerbaijan International, vol. 4 no. 4, Winter 1996.

${ }^{400}$ Dilip Hiro, ”Why is the US Inflating Caspian Oil Reserves”, in Middle Eastern Intelligence, 12 September 1997.

401 See Sam Brownback, ”U.S. Economic and Strategic Interests in the Caspian Sea Region: Policies and Implications”, in Caspian Crossroads, vol. 3 no. 2, Fall 1997.

${ }^{402}$ Ibid.
} 
surveyed and drilled. Nevertheless, the figure 200 billion, which deputy secretary of state Talbott mentioned in July 1997 (and which reached upwards to 240 billion at times), does not actually have any substantial evidence to corroborate it; it remains highly speculative. The phrase 'up to 200 billion' has become the standard mention in US statements. ${ }^{403}$ In reality, half of that figure seems to be a more likely reality; this is to be certain a huge figure; nevertheless the question is why the US is insisting on the unlikely higher one. Nevertheless, the strategic importance of the Caspian becomes clear once it is noted that there seems to be a consensus on the view that a 'secure supply of oil at stable prices' is one of America's 'vital national interests' ${ }^{404}$ Hence even if the Caspian in the final analysis would 'only' hold $7-10 \%$ of world proven reserves, the importance of the region as a diversification of imports, especially given the complexity of American relations with the Gulf states and the region's utter instability, the oil factor would certainly warrant a strengthened US engagement.

In Hiro's analysis, however, 'Clinton is trying to create a false sense of well-being among his constituents that they can go on indulging in ever higher consumption of petroleum and that limitless oilfields lie in Azerbaijan and Kazakstan to be exploited by American and other Western companies' ${ }^{405}$ The logical conclusion of this thesis is that the increased strategic involvement of the United States, taking place at high risks in a potentially explosive region of the world and offsetting an important domestic pressure group, is based on a short-sighted attempt of politicians aimed at deceiving their own people to further their personal careers.

Political manipulations may have a role in the developments, but it seems rather far-fetched that the consistent and multi-faceted policy of increased involvement in this region, that the US has been pursuing openly since early 1997 and tacitly before that, should be devoid of strategic interests. Further, oil alone does not seem to provide a satisfactory explanation for the impressive US efforts to strengthen its influence in Russia's 'underbelly'-monocausal explanations are seldom reliable. Rather, a complete explanation necessitates an analysis of the global strategy of the United States, anchored in the defense establishment, and the place of the Caspian region in this strategy. The importance of oil is overestimated by many observers; in fact a closer look at both statements and policy show this. For example, Sestanovich noted in April 1998 that:

We cannot and should not look at Caspian energy policy in isolation from our overall goals for the region. Our promotion of an economically viable east-west Eurasian transport corridor to bring Caspian energy resources to international markets is part of a larger strategy that supports peace and stability, democracy and respect for human rights, market economic reform and development, openness toward the United States and to U.S. business, and the region's integration into EuroAtlantic and global institutions. ${ }^{406}$

Likewise, Elizabeth Sherwood-Rendall bluntly stated that 'the importance of Transcaucasian oil in driving American policy has been exaggerated. From the perspective of the department of

\footnotetext{
403 Eg. George S. Hishmeh, ”Caspian Basin Seen Not Replacing Middle East as Oil Source”, USIA Washington File, 26 September 1997. (www.usia.gov/products/washfile.htm)

404 See eg. Robert J. Art, "Geopolitics Updated: The Strategy of Selective Engagement”, in International Security, vol. 23 no. 3, Winter 1998/99, pp. 79-113, here at p. 92.

405 See Hiro, ”Why is the US Inflating Caspian Oil Reserves”, op. cit. [400].

406 Stephen Sestanovich, ambassador-at-large and Special Adviser to the Secretary of State for the New Independent States, Statement before the House International Relations Committee, Washington DC, 30 April 1998.
} 
defense, the biggest concern was with the role of the new post-Soviet military establishments in the Caucasian republics'. ${ }^{407}$ The main US interests in the Caucasus have indeed been strategic. In a sense the Russian fears described by two Russian specialists have a point: 'the Unites states [is] seeking the reorganization of interstate relations in the whole of Eurasia whereby there [is] not one sole leading power on the continent but many medium, relatively stable and moderately strong ones ... but necessarily inferior to the United States in their individual or even collective capabilities' ${ }^{408}$ The words of another Russian analyst illustrate that Moscow does not swallow the monocausal explanation centered on oil: 'It is not so much oil as Geopolitics which make Washington so vigorous in the Caspian Sea are. Winston Churchill called it Russia's soft underbelly way back in 1919. And there is no sign that the West thinks differently today. ${ }^{409}$

To explain the American long-term strategic interests in the region, it is useful to consult the recent book The Grand Chessboard, written by the influential above-mentioned former National Security advisor Zbigniew Brzezinski. Brzezinski’s work is important in two ways. First of all, because of the extremely interesting world-spanning analysis made; but also because of the influence Brzezinski's thoughts can be expected to have in Washington. In a sense, beyond simply describing American policy and interests, Brzezinski certainly has a role in shaping it.

According to Brzezinski, the end of the cold war meant that the US achieved a global hegemony, albeit of a 'new type'. ${ }^{410}$ In his words, America

stands supreme in the four decisive domains of global power: Militarily, it has an unmatched global reach; economically it remains the main locomotive of global growth ... technologically, it retains the overall lead in cutting-edge areas of innovation; and culturally, ... it enjoys an appeal that is unrivaled, especially among the world's youth—all of which gives the United States a political clout that no other state comes close to matching. It is the combination of all the four that makes America the only comprehensive global superpower. ${ }^{411}$

Basically, Brzezinski's thought is based on three ideas: First, the idea that the US has a standing in global politics today incomparable to that of any other state in modern history: 'American global primacy is unique in its scope and character' (p. 194); moreover US global primacy is necessary to prevent the emergence of a destructive international anarchy which in the end would affect America itself deeply. Secondly, Eurasia is the center-stage of world politics and the US needs to control the flow of events in Eurasia to sustain its primacy: 'For America, the chief geopolitical prize is Eurasia ... and America's global primacy is directly dependent on how effectively its preponderance on the Eurasian continent is sustained ... Eurasia is thus the chessboard on which the struggle for global primacy continues to be played.' (p. 30-31) Third, the US can not expect to keep this standing indefinitely. Given the exceptional circumstances connected to American primacy-its place in the world economy, its cultural appeal and democratic image, as well as the spectacular fall of its main rival, among other-make it inevitable that US influence will not last forever; indeed, 'the window of historical opportunity for America's constructive exploitation of its global power could prove to be relatively brief, for both

\footnotetext{
407 Sherwood-Rendall, ”US Policy and the Caucasus”, op. cit. [360].

408 See A. Bogaturov and V. Kremenyuk, in Nezavisimaya Gazeta, 28 June 1996. The quotation is translated by Zbigniew Brzezinski in The Grand Chessboard, New York: BasicBooks, 1997, p. 103.

${ }^{409}$ Alexei Leonov writing in Pravda, 8 September 1997.

${ }^{410}$ Brzezinski, The Grand Chessboard, Chapter 1.

411 Ibid., p. 24.
} 
domestic and external reasons' (p. 210). Moreover, 'global politics are bound to become increasingly uncongenial to the concentration of hegemonic power in the hands of a single state. Hence, America is not only the first, as well as the only, truly global superpower, but it is also likely to be the very last (p. 209). The point for America, then, is to forge an 'enduring framework of global geopolitical cooperation'; (p. 214) in other words, to use the short window of historical opportunity to further the current situation of 'relative global peace' into a more cooperative world and hence prevent the emergence of a new global anarchy with potentially disastrous consequences.

Our interest here, naturally, is where the Caspian region, and in particular the Caucasus fits into this picture. If control of-or at least a major influence over-Eurasia is indeed the aim of American strategy, Central Asia is interesting by its sheer geographical location at the Center of Eurasia. Indeed the region forms a major opportunity for influence for a number of reasons. First of all, the states of the Caspian region have recently acquired their statehood and therefore their paths to the future have not crystallized; they remain malleable by regional powers in their neighborhood. It is from this perspective only logical that the US, with an interest in shaping the future of Eurasia, would seize this opportunity to prevent its challengers from spreading the influence and instead anchor its own. A simple look at the map proves that the region is indeed strategic: it borders Russia, China, Iran, Turkey, and Afghanistan; Pakistan and India also have stakes in the region although they lack a border with it. Most of the geopolitical players of Asia are hence represented, and often in competition rather than in concert. Giandomenico Picco noted that 'the Caspian derives part of its appeal because of its neighbours ... the Caspian is perhaps more important because of the value given to it by its different neighbours'. ${ }^{412}$ By the very multiplicity of the interested actors, however, none of them is able to exert a preponderant interest. The previous three chapters have shown that the former hegemon Russia has failed in regaining its primacy in the region; Turkey very briefly thought to replace it but almost immediately understood that its relative geographical distance, economic condition and internal problems made this impossible; and Iran has not even considered to press for such a role, much like China. However, it is interesting to note that a coalition of America with one or more of these states would have a significantly better position to achieve a dominant influence. Currently the candidate for this partnership role is clear: America's reliable ally for half a century, Turkey. The Turkish-Israeli alliance provides America with two rock anchors in the Middle East, whose interests are remarkably similar and whose cooperation, as mentioned in chapter 7, is increasingly strong. Israel's own activities in the Caucasus are remarkable; the largest Israeli embassy in a Muslim country was inaugurated in Baku in 1997. And indeed, while defining the five geopolitically pivotal states of Eurasia, four of them are in the neighbourhood of the Caucasus. Besides South Korea as a Far Eastern Anchor for America, Brzezinski notes the crucial importance of Turkey, Iran, Ukraine and Azerbaijan. In Eurasia, then, Brzezinski notes that 'the states deserving America's strongest geopolitical support are Azerbaijan, Uzbekistan, and (outside this region) Ukraine' (p. 149).

In America's larger strategy, Central Eurasia is a singular opportunity to create a new region of democracy and stability in the middle of Asia, the establishment of which would imply a great success in America's attempts to create the cooperative Eurasia that would be the base for future

\footnotetext{
${ }^{412}$ See Giandomenico Picco, ”The Caspian Region: Is It Really Strategic?”, in Marco Polo Magazine, no. 6, 1998, pp. 22-26.
} 
world politics. Direct and tangible interests are access to the new markets of the region, with a population that is approaching a hundred million people-markets for western goods but also sources of energy, minerals and cotton, in a first stage before the industrialization of these countries. However, one can also imagine that a cooperative, market-oriented and democratizing - one should not have illusions of any rapid creation of western-style democracies in the region-Central Eurasia would have a considerable influence on the developments in its surrounding regions. It seems that certain circles in the US may see Central Asia as a future bastion of stability in Central Asia; the term has indeed already been used for Uzbekistan. Unless American involvement, which is instrumental in deciding the balance among the interested actors in the region, occurs there is a clear risk for a further Balkanization of the area, given the existing internal divisions and possible foreign manipulation. Brzezinski hence coined the illustrative term 'Eurasian Balkans' for the entire region, due to its complex ethno-religious and socio-political characteristics. To name but one example, the center of political Islam in the world has moved from Iran to Afghanistan and its support base, Pakistan; the fear of the Afghan Taleban movement's ability to destabilize the southern states of Central Asia-much like it has been a main reason of the destabilization of Pakistan-is real and has given reason for great worry in many regional states. ${ }^{413}$ But, as Picco notes, it is the very volatility of the developments in and around the region that has increased its importance, including to the United States:

\begin{abstract}
this simply makes the Caspian more and more relevant because so many options are thus opened, as are so many alternatives and so many combinations. Ideological, religious or cultural paradigms are nowhere to be found in the Caspian states. It is possibly their strength and potential in an as yet to be defined new international order. It is also why beyond any oil and gas figures the appeal of the Caspian currently remains so strong. The shifting sands around the region make it so important to know where the region itself will decide to move. ... And the result will have an influence far beyond the shores of the Caspian. For these reasons, it will continue to attract those who economically or politically believe they can play a role. ${ }^{414}$
\end{abstract}

The factor that makes the South Caucasus the most strategically crucial region of the Caspian to America is the very question of access. Central Eurasia is important partly because of its location; however it is its very location which makes access to it by a non-contiguous power difficult. In the current alignments of power, the US road into the Caspian Sea and Central Asia passes through Turkey and the Caucasus; from a Caspian state perspective, the question of oil pipelines westwards becomes crucially important to safeguard true independence and freedom of action vis-à-vis Iran and Russia, in particular: dependence on pipelines through either Russia or Iran would imply also a political and strategic dependence on these states, most likely resulting in these states slipping into the sphere of influence of the Russo-Iranian alliance. This is the central reason why the US has so ardently pushed for the creation of the Baku-Ceyhan pipeline, as underlined by the signing of the Ankara Declaration on Turkey's republic day, 29 October 1998. ${ }^{415}$ The bottleneck of the pipeline question, as well as of the prospect of American, Turkish and other western influence in the region, is the South Caucasus. With a Russian-ArmenianIranian axis ranging in a North-South direction and a US-Turkish-Azerbaijani-Uzbek alignment in the East-West direction, the crucial region of conflicting interests is the Caucasus.

\footnotetext{
413 See Picco, ”The Caspian Region”, p. 24.

${ }^{414}$ See Picco, "The Caspian Region”, p. 26.

415 See Turkish and international press, 30 October 1998.
} 
As a whole, the developments of the last few years have shown that the United States are in the Caspian region to stay. The US has definitively abandoned a policy of viewing the Caucasus and Central Asia as a Russian backyard, ${ }^{416}$ a fact that carries substantial consequences for the Caucasian states. The new general geopolitical situation that these developments entail is most worrisome for Armenia. Due to its disputes with Azerbaijan and Turkey, Armenia is forced-to a large degree against its will-into a closer alliance with Russia and Iran, while necessarily facing the gradual worsening of its relations with the US. It seems as if Armenia's freedom of movement is restricted in a way that it can not remedy in the short term: it has no way to distance itself from the Russo-Iranian alliance, lest it surrender all it claims on Azerbaijan and subordinates to Turkey, neither of which is likely to happen or be accepted by Armenian public opinion. On the other hand, Georgia and Azerbaijan can now contemplate a significantly more promising international environment. Indeed, they are now considerably closer to achieving the aim they have been aspiring to since independence: a strategic relationship with a state strong enough to safeguard their security and independence from Russia. Whereas most western observers would simply laugh scornfully at Georgians who hope that their country will be a NATO member in five to ten years, or to Azeris who wish to see American or NATO bases on their territory as soon as possible, the speed at which the US engagement of the Caucasus and Central Asia has developed warrants the question: Why not? With Russia increasingly unable to project its power and influence beyond or even within its borders, and embroiled in an economic crisis of a magnitude westerners often have difficulties comprehending, it nevertheless maintains a capability to destabilize its southern neighbours. But it is difficult to disagree with Vafa Gulizade that Russia 'could do no more than complain about the idea; people like Zhirinovsky will shout and cry, but that is all'. ${ }^{417}$ A quick survey of US strategy in the second half of the twentieth century has makes it clear that the US prefers to keep military forces in the vicinity of regions it considers important for its national interests. The Caspian region, by its geography, does not allow for the most discrete deployment of military power-aircraft carriers - but requires a true military base of the type deployed in Incirlik in Southern Turkey, which happens to be the most nearby American base to the Caspian sea. In view of recent US policies, a military base in the Apsheron peninsula-overlooking the Caspian sea as well as the entire Caucasus-must indeed seem tempting. Whether the US will eventually deploy military units in the territory of the former Soviet Union or not, whether it will extend its security umbrella to Azerbaijan and Georgia or not, one fact is for sure: US involvement is about to reach such an extent that it becomes irreversible; for simple reasons of international prestige as well as for the sake of real national interests, the United States is not likely to step back from its increasingly bold commitment to strategic involvement in the Caucasus and Central Asia. Meanwhile, the Russian-Iranian-Armenian alliance is only strengthening as a result of this very development, prompting the US to extend ever stronger security guarantees to friendly states, such as Turkey, Georgia, Azerbaijan and Uzbekistan. The American influence in the Caucasus is steadily growing; however its influence remains largely unacceptable to both Iran and Russia. The stage is set for an increasingly serious struggle for control over and influence in the region, the consequences of which remains to be seen.

\footnotetext{
${ }^{416}$ Hürriyet, 5 September 1997.

417 ”Interview-Azeris Want US, Turkish Bases-Aliyev Aide”, Reuters, 25 January 1999.
} 


\title{
8
}

\section{Mediation and the Search for Solutions}

\author{
'I don't want sugar, I don't want flour... I want my land back....Out \\ of one million refugees, we can find 150,000 good men to fight; it is \\ better to die for our land than to die here'.
}

Azeri Refugees in the Saatli camp, Azerbaijan.

\section{The Search for Solutions}

As long as Armenia and Azerbaijan were part of the Soviet Union, the international community had no ability nor jurisdiction to interfere in the conflict. The resolution of the issue was totally the responsibility of the Soviet government. In any case, the conflict was still going on at a rather low scale at the time. The flaring up of the conflict into full-scale war in fact coincided with the break-up of the Soviet Union and the independence of the two republics. Thus other actors now had the possibility to intervene and seek a negotiated solution. Russia, naturally, remained a major influential power, but lost its monopoly position. In the beginning of 1992, a whole range of countries started to take interest in the issue. Immediately following the Khojaly massacre, in particular, international attention was concentrated on the conflict. France and Iran proposed their good offices, with some momentary progress on the Iranian side. ${ }^{418}$

Turkey, as viewed above, initially tried to pursue a neutral and at first sight disinterested policy. President Özal argued for a negotiated solution of the conflict, and proposed to offer Turkey's good offices. However, angered by the Armenian intransigence and actions in Karabakh, Özal issued a statement that "It is necessary to put some fear into the Armenians over Karabakh". ${ }^{419}$ This statement was instantly used by the Diaspora Armenians to discredit Turkey as a neutral mediator. Thus in subsequent CSCE negotiations, the Armenians have refused to accept Turkey's participation in any planned peace-keeping operations. Further, the TurkishAzerbaijani embargo on Armenia contributed to disqualifying Turkey as an impartial actor.

Unilateral mediating attempts followed by Iran, Russia, and other countries, but whenever they did manage to reach a cease-fire this was mainly short-lived, and any attempts at a political settlement never appeared. The cease-fires, although signed by the belligerents, were in retrospect never seriously followed, nor was this the intention of all belligerents simultaneously until mid1994. Rather, a cease-fire was used as an instrument to regroup forces and reformulate strategy.

\footnotetext{
418 Sophie Shihab, "France and Iran Propose Good Offices in Nagorno-Karabakh Conflict”, in Le Monde, 28 February 1992, p. 3.

${ }^{419}$ See FBIS-CIS, 5 March 1993, p. 43, “Ozal Cited on Nagorno Karabakh Events, Armenians”.
} 


\section{The Role of the CSCE/OSCE}

As far as international negotiations are concerned, the United Nations has remained in the periphery of the conflict, limiting its role to issuing Security Council resolutions condemning fighting in general and affirming the territorial integrity of "all states in the region", thus abstaining from defining an aggressor. ${ }^{420}$ Instead, the UN delegated the resolution efforts to the CSCE (Conference on Security and Cooperation in Europe). The CSCE is the only institution to have made significant efforts, so far mostly in vain, to achieve-more than a cease-fire-a lasting political solution to the conflict. The CSCE was at this time looking for a new role in the wake of the Cold War, and seemed to think that conflict management in the former socialist countries of Eastern Europe and the Soviet Union could be a role for the organization to fill. Furthermore, the CSCE has an organizational structure where all member states are equal; there are no great-power vetoes. ${ }^{421}$ The UN was more than happy not to take on a complicated conflict in former Soviet Union, especially given its overload in conflict resolution in the post-cold war era. Moreover, one can speculate that political interests were part of the scheme to entrust the CSCE with the Karabakh conflict. After all, the UN did take on the Abkhazia conflict. Why not the CSCE if it was becoming the prime regional organization? Could the answer be found elsewhere? A very interesting speculation is that by entrusting the CSCE with the Karabakh conflict, this would make possible the exclusion of one country the West wanted to keep out of the Caucasus: Iran. Being a member of the UN but for natural reasons not of the CSCE, Iran was automatically and very tactfully expelled from mediation in the Karabakh conflict. Whether this is a coincidence, a contributing factor or the main reason for the decision of the UN to delegate responsibility to the CSCE will probably never be clear. Nevertheless, the question is interesting in itself.

The March 1992 conference of the CSCE decided to prepare for a final peace conference in Minsk, and for a group of monitors to supervise cease-fires to be set up. The Italian diplomat Rafaeli was given the task to prepare the ground for a peace conference which, it was thought, would be held in June 1992. The Swedish diplomat Mathias Mossberg was given the duty to set up an observer force on the ground. Only, there was no cease-fire to observe, and the parties were far from ready for a peace conference. ${ }^{422}$ Ambassador Rafaeli traveled to the belligerent capitals in an attempt to prepare the June conference, but was met with disdain by parties who both believed they could solve the conflict on their own terms through the use of force. Nevertheless Italian diplomacy succeeded in bringing representatives of Armenia and Azerbaijan to 'emergency talks' in Rome. The participants in these talks soon became known under the informal name of the 'Minsk group', which still today is the body that is responsible for the negotiations under the OSCE.

The mediation process can be divided into four phases. The first was the short phase of Russian weakness and predominance of the CSCE mediation over unilateral mediation attempts by other countries. This mainly means the year 1992. The second phase was the reassertion of

\footnotetext{
${ }^{420}$ Security Council Resolutions on Nagorno Karabakh included resolutions 822 (30 April 1993), 853 (29 July 1993), 873 (14 October 1993), 884 (11 November 1993), as well as a General Assembly resolution of 19 November 1993.

${ }^{421}$ See Dimitry Furman and carl Johan Åsenius, "The Case of Nagorno-Karabakh (Azerbaijan)”, in Clive Archer and Lena Jonson (eds.) Peacekeeping and the Role of Russia in Eurasia, Boulder: Westview, 1996, p. 149.

422 Interview with Mathias Mossberg, Stockholm, March 1999. See also Jan Eliasson and Mathias Mossberg, "Nagorno-Karabach_Den Glömda Konflikten” (Nagorno-Karabakh-The Forgotten Conflict), in Internationella Studier, no. 2, 1998 (Stockholm Institute of International Affairs).
} 
Russian interests that accompanied the policy shift occurring in the second half of 1992, which entailed the replacement of a Euro-atlanticist perspective, in the words of Mohiaddin Mesbahi, to a neo-Eurasianist one. ${ }^{423}$ This translated into practice, as will be analyzed in a later chapter, as the practice of lending support to one party or the other according to the immediate interest of Moscow. This led to the diminishing influence of the CSCE in the conflict. The third phase, from late 1993 to the end of 1996, was characterized by increasing cooperation and confidencebuilding between the OSCE and Russia. This nevertheless led to few practical gains in terms of approaching a resolution of the conflict, although the cease-fire was achieved in this period. The fourth period began in January 1997 as first France and the United States became permanent cochairs of the Minsk group, together with Russia. This period can be said to have lasted until the end of 1997 and the deposition of Levon Ter-Petrosyan as Armenian president, indicating the victory of the hardliners over the pragmatists in Armenia and the rejection by Armenia of the OSCE's step-by-step plan. The fifth phase is the current search for a reopening of negotiations after this event, in which the November 1998 'Common State' proposal must be viewed as an important but unfortunate element.

As mentioned above, the CSCE initially envisaged an eventual peace conference in Minsk and therefore the organs to mediate the conflict received the informal name of the "Minsk Conference" and for the negotiating team, the "Minsk Group”. It is notable that the Minsk Group was created at a time of Russian weakness, as the Russian state and its foreign policy was in a formative phase, as has been seen above. ${ }^{424}$ As a result Russia at first adopted a relatively low profile in the mediation process. However the CSCE's mandate was weak; it had no experience in conflict resolution; and the parties were not interested in a negotiated solution, this being valid especially for the Karabakh Armenians who were increasingly aware of their military superiority. Furthermore, there seemed to be no readiness to provide troops for a peace-keeping operation among the member states. It should be recalled that the Bosnian crisis was unfolding at the same time, and that the problems faced by international peace-keeping in Bosnia-Herzegovina doubtlessly discouraged anybody from sending troops to far-away Karabakh.

The Minsk Group was originally dominated by smaller, disinterested countries. This had a positive and a negative aspect: the mediation process was trusted by all parties as impartial since countries like Sweden, Italy or Finland had no or few interests in the South Caucasus. However, these countries could only act as mediators in the true sense of the word; they had no incentives, no carrots or sticks to convince the belligerents to adopt a more compromising attitude. Moreover, as pointed out by John Maresca, the group was (until 1997) 'too large and too low level for serious negotiation, [having] no way of guaranteeing that the much larger CSCE itself would either agree or actually produce a peacekeeping force'. ${ }^{425}$ This circumstance has been realized by the group and negotiations are now conducted almost exclusively by the 'Troïka' of co-chairmen.

However during 1993, the Karabakh Armenians' push southward towards the Iranian border, threatening Nakhjivan led to a potential internationalization of the conflict, where both Iran and

\footnotetext{
${ }^{423}$ Mesbahi, “Russian Foreign Policy and Security...”, op. cit. [185], p. 192-3.

424 See Rexane Dehdashti, "Nagorno-Karabakh: A Case-Study of OSCE Conflict Dispute Settlement Mechanism”, in Michael Bothe and Natalino Ronzitti (eds.), The OSCE in the Maintenance of Peace and Security, Hague: Kluwer Law International, 1997, pp. 459-478, here at p. 469.

425 John J. Maresca, ”Lost Opportunities in Negotiating the Conflict over Nagorno-Karabakh”, in International Negotiation, vol. 1 no. 4, 1996, p. 472.
} 
Turkey (recalling its protector status over Nakhjivan) could get directly involved. Thus international support for the CSCE efforts to stop the war increased, and the United States, Russia and Turkey put pressure upon the warring parties, who accepted to take part in the mediation of the CSCE.

In June 1993, the Minsk group reached an agreement which set a deadline of six months for a permanent cease-fire. However it also stipulated that Armenians evacuate Kelbajar, which formed a second corridor between Karabakh and Armenia. The Karabakh Armenians, although pressurized by the Armenian republican government to accept the plan, believed that holding Kelbajar was crucial for protecting the lifeline between their territory and Armenia. In any case, the agreement was upset as in the very next month, Armenian forces launched an new attack on Azerbaijani territory. This event typifies the disinterest of the Karabakh Armenians to stop the war. But seeing their position and logic, why would they? After having made themselves guilty of a number of violations of laws of war, carried out ethnic cleansing and a massacre on the civilian population of Khojaly, they received no clear-cut condemnation from any significant state or international organization. Quite to the contrary, the CSCE was making great efforts to have them accepted at the negotiating table. Thus from Stepanakert's point of view, it must have seemed safe to start a new offensive, achieve their war aims, and only then agree to sit down at a negotiating table. This illustrates a familiar problem in conflict resolution. It is very difficult to stop a war when one side still has the potential to solve the issue by arms - that is, before a stalemate has occurred.

Although the CSCE was the organization in charge, all blame should not be put on this organization - it should be recalled the Nagorno Karabakh was the first major conflict in which the CSCE became involved. Lacking any firm institutions and any practice in peace-making, the CSCE did whatever was in its power to stop the war. However, once the parties had no wish to comply with its resolutions, there was no measures the CSCE could take to ensure compliance. There were even substantial difficulties in finding sufficient number of states that were ready to put troops at the organization's disposal for a peace-keeping mission. ${ }^{426}$ As MacFarlane and Minear note, 'the fact that OSCE personnel were unwilling to discuss potential western contributions may have reflected not merely diplomatic discretion but also the difficulty of lining up participants'. ${ }^{427}$ The question of peacekeeping was made utterly complicated by contending opinions on the composition and leadership of an eventual peacekeeping force. Russia has consistently made it clear that it prefers a Russian-only peacekeeping force, similar to the one in Abkhazia. For obvious reasons the CSCE, And later the OSCE, has refused to allow such a force under the OSCE mandate. OSCE officials have emphasized the fear that a Russian-dominated operation would lead to the OSCE acting 'essentially as a cover for a Russian peacekeeping operation'. Turkey and the US, especially, opposed the Russian attempts to carry through its wishes. Later, Russia argued for a force with at least half of its components being Russian; the western states retorted that a third of Russians and another $17 \%$ of other CIS states could be accepted. Russia naturally saw peacekeeping operations as a golden opportunity to place its troops in Azerbaijan, which is the only South Caucasian republic not to have any Russian military on its soil. As for the issue of leadership of the force, Russia naturally insisted on heading the force, in

\footnotetext{
426 Personal communications from diplomats and military officials in Minsk Group member countries.

${ }^{427}$ S. Neil MacFarlane and Larry Minear, Humanitarian Action and Politics: the Case of Nagorno-Karabakh, Providence, RI: T. J. Watson Institute for International Studies Occasional Paper no. 25, 1997, p. 92.
} 
line with Russian doctrine of exclusively Russian peacekeeping on the territory of the former USSR. Nevertheless, the OSCE referred in this instance to established UN practice that the force commander not come from the largest contingent of forces. ${ }^{428}$ These complications, coupled with opposing views from the belligerents on the composition of forces, eventually led to the unusual fact of a cease-fire without peace-keepers, which has nevertheless held considerably well.

\title{
The Russian Challenge to the CSCE Mediation and its Consequences
}

The CSCE's task was further complicated by Russia's role not only in the issue of peacekeeping forces but in the entire mediation process. Whereas from the beginning, Russia was involved in the Minsk group, it became increasingly clear that Russia would not allow an international organization to take its place and hamper its interests in the Caucasus. The Russians sometimes even actively undermined the peace efforts of the CSCE as they conducted parallel unilateral mediation attempts without informing the CSCE. The final cease-fire of 12 May in fact occurred at a time when Mathias Mossberg, the head of the CSCE mediating group, was in the region to promote the CSCE peace plan. Despite his being in the region at the same time, and despite Azerbaijani requests that he and Jan Eliasson should be a party to the talks, neither was invited to take part in the Russian-led cease-fire negotiations. The Russian actions were so blatantly uncooperative that the American representative to the OSCE John Maresca later denounced it in quite open terms:

\begin{abstract}
At first, Russia fully supported the Minsk group. But in 1993 Russia reactivated its earlier independent mediation effort .... Russia wished to reestablish its dominance in the region and to exclude outsiders, namely the US and Turkey... Moscow would like to reestablish control of the former [Azerbaijani] Soviet frontier with Turkey and Iran, and to share in Azerbaijan's oil riches. To accomplish these aims, Russia has been pressuring Azerbaijan to accept the reentry of Russian troops as ... border guards. ... For leverage, the Russians have used an implicit but dramatic threat: If Azerbaijan does not comply, Russia will step up its backing for Armenia ... with disastrous military results for the Azeris. ${ }^{429}$
\end{abstract}

The developments that surrounded the eventual establishment of a cease-fire are a case in point. Ever since September 1993, the Swedish mediators had exerted substantial efforts to stitch the Russian and CSCE mediations together. However, when the CSCE organized talks in Paris, the Russian mediator Kazimirov - himself a member of the Minsk Group-did not appear, instead trying to stage parallel talks in Moscow. By April 1994, the Armenian forces were making substantial gains in the Terter region, as mentioned above (see p. 39). It was at this point, where Azerbaijan was literally threatened to be severed into two pieces with the Ganja area isolated from the rest of Azerbaijan, that President Aliyev for the first time accepted an unconditional ceasefire, not limited in time. As ambassador Mossberg traveled to Yerevan to get President TerPetrosyan's approval, the Armenian president noted his acceptance but expressed concern regarding Russia's absence. In fact, the CSCE mediators had constantly invited Russia to take part in its increasingly fruitful efforts. Russia nevertheless insisted that a permanent cease-fire be signed under Russian and not CSCE supervision—something which Moscow was able to make

\footnotetext{
${ }^{428}$ Ibid., p. 92, quoting a 'senior diplomat from a neutral member of the OSCE'.

${ }^{429}$ John J. Maresca, “Agony of Indifference in Nagorno Karabakh”, in The Christian Science Monitor, 27 June 1994, p. 19, as quoted by Human Rights Watch / Helsinki, Azerbaijan : Seven Years of Conflict.
} 
happen through its various levers on the parties, despite the fact that the CSCE mediation had been instrumental in bringing about the parties' consent to such a cease-fire. ${ }^{430}$

Practically, the existence of parallel mediation tracks led to the parties' attempts to play one mediation out against the other to go 'forum shopping', in the words of Eliasson and Mossberg. The CSCE mediation efforts had quite a limited chance of succeeding already from the start, and its task grew impossible as Russia started to undermine its activities. At the CSCE Budapest summit of December 1994, the CSCE had to acknowledge this state of affairs by agreeing to integrate its mediation process with the Russian one. This may be seen as either a setback in terms of the organization's authority, just as it was changing its name to the OSCE-one step up from a 'Conference' to an 'Organization'; or as a success in that the OSCE succeeded in integrating Russia into itself. As a result the Russian mediator was given the post of permanent co-chairman of the Minsk Group, together with the rotating OSCE co-chairman, at first held by Sweden and since April 1995 taken over by Finland, which held the post until the end of 1996. During this period of negotiations, few actual steps toward a resolution were undertaken, although the mediation process can be seen as having been instrumental in keeping the parties from descending into renewed skirmishes, although a military stalemate seemed in place, decreasing the risk of renewed warfare: the Karabakh Armenians were hardly poised to conquer and defend any new territories, and the Azeris had little prospects of regaining any, as proven by the huge losses in the counteroffensive in early 1994.

Rather, the mediation efforts were helpful in cementing the existing cease-fire. Furthermore, this period was important for the harmony of the peace talks, strengthening the unity of the mediators and restoring the credibility of the Minsk process by incorporating Russia into it. This was to a large extent due to the choice of the co-chairmen of the OSCE: Sweden and later Finland, two countries which were neutral during the cold war and were to some extent trusted by Russia; and furthermore, two countries with a high degree of experience of relations with Russia. It is relatively safe to say that Russia would have been considerably more reluctant to allow great powers like France and the United States to become co-chairmen in 1997 had it not been for the confidence-building between the OSCE and Russia which took place in 1995-1996. This was, according to Finnish co-chairman Heikki Talvitie, the main accomplishment of his mediation period. ${ }^{431}$ However, the Minsk process became for the parties not mainly a forum for negotiations, but rather, as Gerard Libaridian has put it, a 'propaganda forum for both sides'. ${ }^{432}$

Another important event was the Lisbon summit of the OSCE in December 1996. A draft statement prepared by the Minsk Group had been approved or at least accepted by all countries of the OSCE including Azerbaijan. The document called for a settlement of the conflict based on Azerbaijan's territorial integrity, a legal status for Karabakh giving it the highest degree of selfgovernment within Azerbaijan, and security guarantees for Karabakh's population. Armenia used its right of veto to force the summit to omit a statement on settling the Karabakh conflict from the meeting's final document. The summit had been preceded by intense lobbying by Turkish and Azerbaijani as well as Armenian delegations. Faced with an unanimous vote against it, Armenia

\footnotetext{
430 See Eliasson and Mossberg, ”Nagorno-Karabach..”, p. 7; personal communications from ambassador Mossberg, March 1999.

431 Personal communication from Heikki Talvitie, Stockholm, November 1997.

432 Gerard Libaridian, "Time is on Neither Side”, in Gerard Libaridian and Arif Yunusov, New Approaches to Nagorno-Karabakh: A Window of Opportunity?, East-West Institute Policy Brief no. 3, 1998.
} 
finally vetoed a statement, which had not been the subject of negotiations, as it would have upheld the territorial integrity of Azerbaijan. It showed very clearly that the Armenians were struggling hard not to give up any of their gains from the war; thus Armenian representatives were reluctant to sign a document which reiterated the territorial integrity of all member states. ${ }^{433}$ The Azeris, on the other hand, pressed for a declaration supporting the highest degree of autonomy for Nagorno Karabakh. The summit was saved as the Azerbaijani president, after an intervention by Turkish president Süleyman Demirel, was willing to compromise on the inclusion of a provision on autonomy as the solution of the conflict Thus the outcome was a chairman's declaration on the Karabakh. As the drafts on the conflict could not be incorporated in the final document of the summit, the chairman attached a special note to the document which made clear the position of all OSCE member countries except one: the defense of the principle of territorial integrity. This meant a diplomatic victory for Azerbaijan although technically Armenia had been able to make its veto prevail. In a sense the summit meant a turning point in the history of the conflict; it can broadly be said that before this summit, there was a general tendency of the international opinion to favour Armenia; after the summit most international powers have been increasingly turning to Azerbaijan, for mainly economical reasons related to the oil riches of the country. It also signaled an increase in the level of international attention to the conflict. The Lisbon summit thence supported the maintenance of the territorial integrity of Azerbaijan and an extensive, internationally guaranteed autonomy for Nagorno-Karabakh. The Lisbon summit roughly followed Azerbaijan's position on the conflict, accepting what president Aliyev had termed the unacceptability of the creation of a 'second Armenian state' in the South Caucasus. As a corollary, Armenia and Nagorno-Karabakh felt the Lisbon summit prejudiced further negotiations by siding with one of the parties to the conflict and defining the model of solution before actual negotiations. Armenia and Nagorno-Karabakh have continuously resisted the OSCE's insistence that negotiations follow the Lisbon principles; Armenia even considers the Lisbon principles the main impediment to a solution of the conflict. ${ }^{434}$

\section{7-1998: A Semblance of Progress-but a Backlash?}

In December 1996, Finland's tenure as co-chairman was expiring, and both France and the United States voiced their interest for replacing Finland, pointing to the increasing interest of great powers for the region. As the OSCE picked France as Finland's successor, this disappointed the United States and angered Azerbaijan, which perceived France as pro-Armenian and asked the OSCE to reconsider its decision and appoint the US to the post. This in itself was a watershed, as the US previously had been perceived by Azerbaijan as pro-Armenian as well. Azerbaijan had long had a positive relationship with the US state department, but had been wary of the proArmenian Congress' influence and therefore had not promoted increased American involvement. What had changed was first of all that Azerbaijan judged the influence of the oil lobby in Washington to have superseded that of the Armenian lobby, or simply that the congress had little influence on US foreign policy in the congress as compared to the State Department. Furthermore, the Turkish-Israeli ties were strengthening considerably and there are indications that the Jewish

\footnotetext{
433 "OSCE Summit Unable to Overcome Karabakh Stalemate”, Jamestown Monitor, 4 December 1996; Turkish Daily News, 3 December 1996, p. A1 and A6; ”Karabakh Rebuffs OSCE”, Jamestown Monitor, 13 December 1996.

${ }^{434}$ This was made clear by Armen Baibourtian, deputy foreign minister of Armenia, to the author during an interview in Yerevan in October 1998.
} 
lobby in Washington was beginning to lend its support to Turkey as well as Azerbaijan against the Greek and Armenian lobbies. In any case, Azerbaijan by now felt it could trust the US; two years earlier, neither France nor the US would have been acceptable to Azerbaijan. As the issue of the co-chairman was becoming embarrassing for the OSCE, a compromise solution was adopted: the United States were made a third co-chairman despite Russia's initial opposition. Hence ever since, a troïka composed of Russia, France and the US have been leading the negotiations over Nagorno-Karabakh. By May 1997, the United States publicly declared its interest in quickly achieving a solution to the conflict. ${ }^{435}$ Roughly at the same time, Robert Kocharyan, President of Nagorno-Karabakh, was appointed prime minister of Armenia. This event meant a strengthening of Stepanakert's position in Yerevan and a counter-balance to Ter-Petrosyan's more liberal position. In July, president Aliyev visited Washington on an official invitation, an event which Baku did not fail to utilize to its maximum in propaganda. ${ }^{436}$

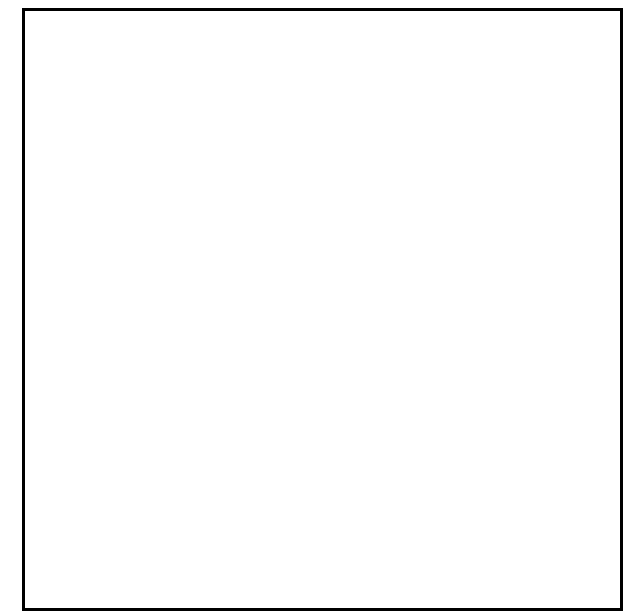

Figure Error! Unknown switch argument.:

\section{Robert Kocharyan}

In September 1997, the OSCE troïka proposed a new peace proposal for Karabakh. This plan provided for the institution of a step-by-step solution, whereby the issues of troop withdrawal from Armenian-occupied territories and the return of refugees would be solved in a first set of negotiations; the issue of the status of NagornoKarabakh would be left for a second step. ${ }^{437}$ This proposal was immediately rejected by the Karabakh Armenian leadership, which refuses any plan which would restore Nagorno-Karabakh to Azerbaijani sovereignty, but endorsed by Baku. ${ }^{438}$ Yerevan's answer was nevertheless the most important, in that TerPetrosyan accepted the principles of the plan, hence opposing Stepanakert's position. ${ }^{439}$ Among other statements, he claimed that it was 'not realistic' to demand Nagorno-Karabakh's unilateral secession from Azerbaijan. ${ }^{440}$ By accepting the peace plan, Nagorno-Karabakh would in the final negotiations on its status be deprived of its main bargaining chip: the occupied territories in Azerbaijan. Hence it was relatively predictable that Stepanakert would reject such a suggestion. Ter-Petrosyan's view was based on a realization of the national interests of Armenia, as opposed to the interests of Karabakh. From Yerevan's perspective, a pragmatist like Ter-Petrosyan realized that the achievement of international recognition for Nagorno-Karabakh or its attachment to Armenia was as good as impossible.

\footnotetext{
435 See Paul Goble, ”Analysis From Washington—Dealing on Karabakh”, in RFE/RL Report, 29 May 1997.

436 See eg. The book Azerbaijan Oil in the World Policy, or the Turkish version Dünya Siyasetinde Azerbaycan Petrolu, Istanbul: Sabah Yayínlarí, 1998, officially stated as written by Heydar Aliyev himself, although his role most probably was more that of an editor. Another interesting example is the chronology of Aliyev's time in power so far entitled Years Gone By, Years Ahead, in which the two only photographs covering two entire pages are both pictures of Aliyev with President Clinton.

437 RFE/RL, "OSCE Offers to Defer Nagorno's Status”, 29 September 1997; Roland Eggleston, ”Armenia/Azerbaijan: Negotiators Try New Approach”, RFE/RL Report, 30 September 1997.

${ }^{438}$ RFE/RL, 13 October 1997.

${ }^{439}$ RFE/RL Newsline, 1 and 20 October 1997.

${ }^{440}$ RFE/RL Armenia Report, 12 November 1997.
} 
Moreover, time was not acting in Armenia's favour. Baku's international standing was rapidly rising, as were Azerbaijan's prospects for wealth — in the midst of the squabble in Armenia, Azerbaijan celebrated the official start of Caspian oil production on 12 November. ${ }^{441}$ Meanwhile, Armenia remained economically deprived with few possibilities of overcoming the AzerbaijaniTurkish embargo on the country. Armenia was still in a position of military superiority, but Azerbaijan's prospective wealth entailed that this situation could rapidly be reversed. Hence it was necessary for Armenia to settle its differences with Azerbaijan before its bargaining position deteriorated even further. However, few Armenians were ready to accept this line of thought. Within his own cabinet, Ter-Petrosyan found harsh resistance from leading ministers. Naturally, the leading opponents were Prime Minister Kocharyan and Interior and National Security Minister Serzhik Sarkisian, both with a past in the administration of the Nagorno-Karabakh, as well as the powerful defence minister Vazgen Sarkisian. Moreover, the opposition united in its opposition to the President's policy, which they deemed as defeatist and treacherous. TerPetrosyan seems to have believed that the 'silent and sensible majority ${ }^{\text {,42 }}$ was supportive of his conciliatory position, expecting peace to help improving Armenia's disastrous economic situation and living standards. In retrospect, it is clear that he was mistaken as concerns public opinion. The subsequent election of Kocharyan seemed to suggest that a majority of Armenians still put the emotional issue of Nagorno-Karabakh before Armenia's economic and material well-being, lending credence to the view that many Armenians are not ready to give up Karabakh at any price. By mid-November, the opposition had organized itself against the President's policy and increasingly virulently condemned his position on the conflict. Practically all political parties, save the ruling Armenian National Movement, took part in this. By mid-January, after a few weeks of relative calm, the rift within the governing elite became clearer. Kocharyan publicly ruled out subordinating Karabakh to Azerbaijan, while allegations were made that NagornoKarabakh officials were planning to topple Ter-Petrosyan. ${ }^{443}$ By the end of January, the differences had resulted in a leadership crisis in Armenia, and the opposition now openly called for Ter-Petrosyan's resignation. Key allies of the president resigned and defections in the ruling party in parliament appeared, further weakening the president's position. ${ }^{444}$ On 3 February, this 'palace revolt' forced President Levon Ter-Petrosyan to resign. In his place, Kocharyan was named acting President according to the constitution. ${ }^{445}$ Presidential elections were scheduled for 16 March, and three main contenders emerged: Kocharyan, the Soviet-time Communist Party leader Karen Demirchian, and the main opposition leader under the fallen regime, Vazgen Manukyan. Among these, Demirchian was likely to be the most compromise-oriented candidate of the three, with Manukyan and Kocharyan staunchly defending the independence of NagornoKarabakh. The election came to be dominated by Kocharyan and Demirchian, Manukyan proving to be unable to gather the level of support he had commanded in 1996. In the first round of the election, Kocharyan polled close to $40 \%$ and Demirchian 27\%, amid allegations of irregularities,

\footnotetext{
441 See RFE/RL, ”Azerbaijan: Caspian Oil Production Begins”, 12 November 1997.

442 As stated by an editorial in the Armenian daily Hayastani Hanrapetutyun, 5 November 1997. (RFE/RL Armenia Report, 5 November 1997.)

443 See RFE/RL Newsline, 15 January 1998, and RFE/RL Armenia Report, 29 January 1998.

444 See $R F E / R L$ Reports, 2 and 3 February 1998.

445 See $R F E / R L$, 4 February 1998; Emil Danielyan, ”Armenian President's Resignation Likely to Cause Policy Changes”, RFE/RL Report, 5 February 1998; Paul Goble, ”Why Ter-Petrosyan Fell”, RFE/RL Report, 6 February 1998.
} 
confirmed by international observers, who nevertheless deemed the magnitude of the irregularities not having been able to influence the outcome of the vote. ${ }^{446}$ In the run-off with Demirchian, Kocharyan recorded over $60 \%$ of the votes and was elected President. This despite the technical illegality of his candidacy: Kocharyan is actually not an Armenian citizen, although the constitution stipulates that the President must have been a citizen for ten years. Kocharyan, as a citizen of Nagorno-Karabakh, might naturally have used the Armenian parliament's 1 December 1989 decision on the unification of the two entities to legitimize his eligibility. Interestingly, this argument was not used, probably not to draw international attention to the decision - it would have given Baku an opportunity to point to Armenia's involvement. The irony is that an Azerbaijani citizen now is the President of Armenia.

Kocharyan's arrival to power was naturally greeted with despair by those that had hoped for a peaceful solution to materialize. It meant that the OSCE proposal was once and for all buried and that the mediation process, in many ways, was back to square one. However, certain observers identified a positive aspect: Ter-Petrosyan, although willing to compromise, had seen his political basis to do so eroding. His legitimacy was simply too eroded for him to carry home a compromise solution against the hard-line opposition. On the other hand, Kocharyan-with his strong identification with Stepanakert — can hardly be blamed for betraying Karabakh, even should he advocate a compromise. According to this line of thought, Kocharyan-as President of Armenia - will soon realize what Armenia's interests are and will be forced to act accordingly. As a result the likelihood of a solution may have increased rather than decreased. However, this argument presupposes that Kocharyan will change the way he looks at the issue, something which can hardly be taken for granted. With his roots in Karabakh, Kocharyan is unlikely to agree to give up the independence Nagorno-Karabakh fought for and won in the war effort in which he played an important role. The bottom line remains that until and unless a clear majority of the Armenian people favour concessions to Azerbaijan, the situation will remain roughly the same.

In November 1998, the OSCE Troïka presented a proposal to the parties that has come to be called the 'common state' or 'unitary state' approach. The OSCE returned to a 'package' solution, thus abandoning the phased approach. One new character of the proposal was to avoid use of terms such as 'autonomy' and 'territorial integrity' which had in the past evoked polemics from the rival sides, these terms having become heavily value-laden. ${ }^{447}$ Although the exact details of the proposal have not been made public, it seems clear that the idea envisages that NagornoKarabakh and Azerbaijan form a 'common state'. OSCE mediators have declined to specify, however, if the two entities would enjoy equal status as is demanded by the Armenian side. ${ }^{448}$ The 'common state' concept is a brainchild of then Russian foreign minister Yevgeny Primakov and his deputy Boris Pastukhov, and has been used by Russia in negotiations over Transdniestria and Abkhazia. The concept is inherently vague, and the belief of the authors of the concept is that it is vague enough to bring the opposing sides to the negotiating table. In the other two cases, Transdniestria and Abkhazia have interpreted this principle as entitling them to separate statehood first, and to negotiating the 'common state' later as equal parties. The Moldovan and Georgian governments, on the other hand, have interpreted the concept as precluding full independence of

\footnotetext{
446 Emil Danielyan, ”Armenia: Tension Follows Presidential Election”, RFE/RL Report, 17 March 1998.

447 Lawrence Sheets, ”OSCE Karabakh Proposals”, Reuters, 9 November 1998.

448 RFE/RL Armenia Report, 10 November 1998.
} 
the breakaway regions, although entitling them to full autonomy within a single state. In the view of analysts at the respected Jamestown Foundation, the proposal 'has deepened the stalemate, postponed the resolution of conflicts, and maximized Russia's leverage upon all parties as arbiter' ${ }^{449}$

As the proposal meant that the OSCE stepped back from its Lisbon principles of defending Azerbaijan's territorial integrity and advocating Nagorno-Karabakh's autonomy within Azerbaijan, the Armenian side predictably endorsed the plan. In the words of Nagorno-Karabakh leader Arkady Gukhasyan, the plan 'envisages direct negotiations between Azerbaijan and Karabakh as coequal parties, poses no "preliminary conditions" - that is, do not postulate Azerbaijan's territorial integrity — and introduce "unconventional elements" necessary, in the Armenian view, in order to overcome the contradiction between the territorial integrity principle and the national self-determination principle', hence fulfilling many of the earlier demands of the Armenian side. ${ }^{450}$

Azerbaijan, on the other hand, almost immediately and predictably refuted the proposal. According to Baku, the plan 'departed from the OSCE's own norms, blindsided Azerbaijan virtually on the eve of the OSCE's year-end conference, and appeared designed to shift onto Baku the blame for the mediators' ineffectiveness'. ${ }^{451}$ According to Vafa Guluzade, the Minsk group introduced a potentially dangerous element in the negotiations by accepting the 'common state' idea as the basis of a settlement. He blasted the group for having 'set themselves the task not of settling the conflict, but of inventing something in order to begin negotiations.... There are no U.S. or French positions here. The 'common state' is an invention of Russia's Foreign Ministry. The latter is attempting to impose it on Georgia in the negotiations on Abkhazia, but Georgia is rejecting it. This idea was applied in Moldova's Transdniester region. Now the Russian Foreign Ministry is attempting to apply its tactics also in Azerbaijan, and it looks as if the United States and France are hypnotized'. ${ }^{452}$ Gulizade singled out several major drawbacks in the OSCE's abrupt shift. First, the ambiguous concept of 'common state' was an inherently contentious and unstable basis for any settlement. Second, the OSCE's lurch from insistence on "territorial integrity" to an opposite principle undermined the OSCE's own influence. And third, the shift rewards Armenia's intransigent elements, showing that the overthrow of Ter-Petrosyan had paid off. ${ }^{453}$ As refers to rewarding Armenia's intransigent elements, Kocharyan indeed stated that 'the change of leadership in Armenia played a great role in securing these gains for the Armenian side', hence crediting the deposition of Ter-Petrosyan for the advances. In any case the result was a prolongation of the conflict and a further delay of its solution. Gulizade's statement that the OSCE espoused an 'opposite principle' to that of territorial integrity is nevertheless questionable; the common state approach does not mean a denial of the principle, although by refraining from mentioning it, it represents a deviation from the erstwhile approach which held territorial integrity central to any solution. The consequences of the proposal in practical terms, as far as can be observed in early 1999, seems to have been to delay the prospects for a lasting peace. In fact, the Armenian side has announced that under no circumstances will it make any compromises beyond

\footnotetext{
449 Jamestown Monitor, 12 November 1998.

${ }^{450}$ Noyan Tapan, 11 and 12 November 1998; Jamestown Monitor, 13 November 1998.

451 Jamestown Monitor, 2 December 1998.

452 Jamestown Monitor, 3 December 1998.

453 Jamestown Monitor, 1 December 1998.
} 
those that the acceptance of the common state proposal would imply; indeed, the tenacity of the Armenian side has increased substantially with this plan; both Yerevan and Stepanakert see the recent developments as a political victory. Much like Azerbaijan relied on the 'Lisbon principles' and Armenia's intransigence to accept them in its foreign relations, Armenia is now in a position to depict Azerbaijan as the party that refuses to comply and has therefore no incentive to compromise. Meanwhile, the Azerbaijani side is increasingly disgruntled with OSCE mediation and has publicly announced that other mediation bodies may be conceived of. The failure of the mediation hence lies in an inability to gauge what proposals can be accepted by both parties. It was relatively obvious that the step-by-step plan would ultimately be refused by the Armenian side; its announcement was therefore instrumental in handing Azerbaijan a diplomatic victory. Likewise, Azerbaijan's refusal to the common state approach was equally predictable, and its announcement was therefore an obvious Armenian diplomatic victory. By its actions, the Minsk group hence actually increased the unwillingness of one party to the conflict to make serious compromises, instead putting itself into a position that is best described by Libaridian's abovementioned phrase: a propaganda forum for both sides.

An interesting observation is that the increased involvement of great powers in the mediation process has worsened rather than promoted the prospects of a solution. Great power mediation undoubtedly has the potential of being effective whenever the great powers involved pursue the cause of peace and not their own, narrow national interests, and are interpreted as neutral and disinterested by the parties. In fact, the record in the Nagorno-Karabakh conflict has not given any reason to view either Russia or the United States as disinterested mediators. Russia has an intimate military relationship with Armenia and is continuously arming that country, whereas the US are developing ever closer ties with Baku, without however compromising its ties to Yerevan. In this sense, both great powers are correctly viewed by most observers as pursuing their own national interests in the Caucasus. In the case of Russia, it is doubtful whether a solution to the Nagorno-Karabakh conflict would at all be perceived in Moscow as being in Russia's interest; as far as the US is concerned, the intentions of Washington nevertheless seem less self-interested. However, the national interests of the US in the Caucasus, as outlined above, dictate that Washington's priority must be a close relationship with Baku—something which naturally creates suspicion in Yerevan. In certain ways, the progress made during the years of small-power mediation seems to have been much greater than the present condition of the peace process. Unfortunately, a return to small-power mediation is nevertheless unlikely to yield results. The great powers are in the Caucasus to stay; as such it is better to have them involved in the mediation process than the opposite. At least, the opportunity for the parties to go 'forumshopping' is limited today, whereas a return to small-power mediation would be likely to lead to precisely that.

\section{The Position of the Parties and Obstacles to a Solution}

At present, it is crucial to identify the practical obstacles to a solution as observable in the positions of the parties in concrete matters; the main points of contention should be bore in mind. The respective standpoints of Azerbaijan, Armenia and the Karabakh Armenians are in essence the same as they were before and during the war, although a slow motion towards a compromise is observable. Azerbaijan insists on the restoration of its territorial integrity, implying the return of the territories occupied by the Armenians, including both Nagorno Karabakh itself and its neighbouring territories. The Karabakh Armenians, backed by Armenia, view the ideal solution as 
the granting of independence and international recognition to the Republic of Nagorno Karabakh, which would include the Lachin corridor. They refuse any solution by which Nagorno Karabakh would fall within the (even nominal) jurisdiction of Azerbaijan. Most importantly, they refuse to enter into 'vertical' relations with Azerbaijan. Therefore the minimal solution the Karabakh Armenians are ready to accept is a form of union, confederation, or federation which would guarantee Armenia and Nagorno-Karabakh unrestricted contact opportunities. ${ }^{454}$

Most foreign actors have positioned themselves between these extreme viewpoints, defending the territorial integrity of Azerbaijan but also at the same time the right to self-determination of the Karabakh Armenians. This seems to be the position of the OSCE and its member countries as well, as can be observed in the stormy Lisbon summit in December $1996,{ }^{455}$ and lately in the OSCE's peace proposals.

The first and most important issue impeding a solution is naturally the question of Nagorno Karabakh's status. Unification with Armenia or independence is still the aim of the Stepanakert government. In negotiations, they have the upper hand by the fact that this has in practice already been achieved and therefore any other solution would be a concession from their side. Azerbaijan, on the other hand, is not ready to allow the partitioning of its territory, but is prepared to give the Armenians a 'highest degree of self-rule and autonomy', claiming that it would be 'less than independence but more than autonomy'. ${ }^{456}$ Azerbaijan hence refuses to grant Nagorno Karabakh the right to secession, but is ready to accord the 'highest degree of autonomy' to the enclave. this proposition nevertheless remains on an abstract level, and there is a need to articulate it and translate it into a concrete proposal. When asked of the details of the Azerbaijani position, officials are unwilling or unable to elaborate. Beyond the obvious statement that exact details have to be worked out during negotiations, Azerbaijan's position is that Nagorno-Karabakh would enjoy self-rule but no role in foreign affairs, defense, and nation-level taxation. As regards the thorny issue of the Nagorno-Karabakh army, Azerbaijani foreign minister Tofiq Zulfugarov was unequivocal and somewhat ironical:

In any form of solution within the framework of he Azerbaijani state, what would be the need for a separate Nagorno-Karabakh army? Against whom would it be directed—obviously against Azerbaijan. Can you have within one state two separate armies which are moreover pointed against each other? Give me an example of any such solution that works, and we shall study it. ${ }^{457}$

Nevertheless the fact that Azerbaijan does not clarify its stance, and its vision of the future of Nagorno-Karabakh within Azerbaijan, is a problem. The fact is that when asked in detail, Azeris — be it intellectuals, journalists or government officials — seldom have a coherent view of what such 'broad autonomy' would be in practice. This in turn increases further the suspicion of

\footnotetext{
454 Arif Yunusov, "The Status of Nagorno-Karabakh: The Root of Conflict”, in Gerard Libaridian and Arif Yunusov, New Approaches to Nagorno-Karabakh: A Window of Opportunity?, East-West Institute Policy Brief no. 3, 1998.

455 For an overview of the summit, see Turkish Daily News, 3 December 1996, pp. A1 and A6. Although Armenia prevented a resolution affirming the territorial integrity of all member states from being adopted, thereby preventing an implicit recognition of Nagorno Karabakh's belonging to Azerbaijan, the final document of the meeting included a separate statement on Nagorno Karabakh, which was relatively favourable to the Azerbaijani side, in fact directing hard criticism against the Armenian side for blocking the peace process.

${ }^{456}$ Personal communication to the author from Vafa Gulizade, Azerbaijani presidential advisor, Ankara, 1995.

457 Interview with Tofiq Zulfugarov, Baku, October 1998. Translation from Azeri is my own.
} 
the Karabakh Armenians that Azerbaijan does not intend to give Nagorno-Karabakh any real autonomy in the long run. Karabakh officials hence put the problem as follows:

There are many different levels of autonomy, the highest being independence. Azerbaijan had to decide which one it was talking about. Was it Bosnia, Tatarstan, or what? The problem is that they are unwilling to concretize their proposal. ${ }^{458}$

Lately the leadership of Stepanakert has voiced its interest for discussing a loose confederation with Azerbaijan. Kocharyan also endorsed this plan, reminding that Stepanakert must be given an equal status with Baku in such a confederation. ${ }^{459}$ In other words, the insistence of Stepanakert remains on the subject of what the Armenian side terms 'horizontal relations' with Azerbaijan. As a result, the position of the parties remain relatively far from one another, although a certain softening of maximalist aspirations has taken place in the past year. In the words of Armenian deputy foreign minister Baibourtian, the Armenian side has 'no preconditions'-referring to Azerbaijan's precondition of territorial integrity —and advocates a confederal or federal solution. Something that seems to be a precondition, though, is the advocacy of 'horizontal relations between Baku and Stepanakert on which the Armenian side is uncompromising at present. ${ }^{460}$

The second point is the areas of Azerbaijan, outside Nagorno-Karabakh, that are occupied by Armenian forces. The Karabakh Armenians are ready to give up most lands to the East, North, and South of Nagorno Karabakh to Azerbaijan, but refuse to surrender the Areas to the West, especially the Lachin corridor linking Nagorno Karabakh to Armenia. In the words of one Karabakh official, "We will never be an enclave again'. Azerbaijan, on the other hand, unconditionally urges the return of all lands outside Karabakh to Azerbaijan, and furthermore demands this to be done as a prerequisite for direct negotiations on status. This in itself is a deadlocked situation, as Stepanakert refuses to give up this main bargaining chip. Meanwhile, Azeri refugees in eastern Azerbaijan increasingly lose hope of ever regaining their homes. The Azerbaijani government also hinders this population from resettling elsewhere and integrating into Azerbaijani society, as this would mean the eviction of this population was a fait accompli; the use of the refugee issue would become impossible. In this sense allegations have been made that the Azerbaijani government is using the refugees as pawns in a political game. However, the failure of the phased solution plan and the resignation of Ter-Petrosyan in early 1998 changed the situation of the refugees. Whereas until then many of them had had high hopes for an impending solution and return, many refugees after these events seem to have lost hope of returning to their homes in the near future. As a result, many took steps to take up permanent residence in other parts of Azerbaijan. ${ }^{461}$

The issue of Lachin is perhaps one of the most difficult nuts to crack in the entire conflict. For Nagorno-Karabakh not to 'be an enclave again', some form of effective guarantees for contacts with Armenia must be necessary. The Azerbaijani side, nevertheless, remain suspicious of what Stepanakert will use this corridor for. As Zulfugarov has stated, 'a corridor can not be for

\footnotetext{
${ }^{458}$ Quotation from a 'leading foreign ministry official' in Stepanakert in MacFarlane and Minear, Humanitarian Action and Politics: the Case of Nagorno-Karabakh, op. cit. [427], p. 88

${ }^{459}$ RFE/RL Newsline, 15 January 1998.

${ }^{460}$ Interview with Baibourtian, Yerevan, October 1998.

461 Interview with Karl Naucleer, head of the International Federation of Red Cross and Red Crescent Societies representation in Baku, October 1998.
} 
economic purposes. Any solution would require the two republics [Armenia and Azerbaijan] to develop economic linkages in the form of a free-trade area. We buy goods from western Europe, from America, without a corridor' ${ }^{462}$ Zulfugarov, although not expressing it in direct words, clearly suggested that the corridor is intended for military purposes, for the event of an Armenian military intervention to support Nagorno-Karabakh—and as such unacceptable to Azerbaijan. However, a positive and interesting circumstance is that the Yerevan government has a more liberal attitude to the issue of Lachin. When Baibourtian was asked whether Lachin, given effective international security guarantees for Karabakh, could be returned to Azerbaijani jurisdiction, his answer was simply 'Yes'. Hence there might be a way out of the Lachin imbroglio.

Other important practical issues are the safe return of refugees and the creation of buffer zones once occupied territory has been returned. As regards refugees, a problem is that according to the few reports that exist from the occupied territories, the houses of the Azeris who fled have been looted, often burnt, and sometimes mined by the Karabakh Armenians. Hence a return of refugees would have a potential to lead to a desire for revenge among civilian Azeris; one can easily imagine the reactions of frustrated people to such conditions. Here landmines are especially important. Moreover, the issue of international guarantees and peace-keeping troops are essential but can only be decided in conjunction with a solution to the core issues. Nevertheless, the question of guarantees will be crucial to any solution of the conflict given the distrust that is reigning between the parties. Armenians, for example, are heavily suspicious of the international community's actual will to protect Nagorno-Karabakh. In the words of Baibourtian, 'Armenia has been given guarantees before [referring to the time of the first world war primarily]; any nation which has suffered a Genocide needs to be careful' ${ }^{463}$

A third point, although not in the core of the problem, is the fact that Azerbaijan is partitioned between mainland Azerbaijan and Nakhjivan. The two parts of the country have no territorial connection, and are separated by Zangezur, which belongs to mainland Armenia. Azerbaijan would naturally want to connect the two parts of the country, whereas Armenia does not want to give up any land, notably as that would cut off Armenia from Iran, one of its main trading partners, and encircle it even more in a hostile, Turkic world.

A very important impediment to the resolution of the conflict is in the realm of attitudes. As noted throughout the text, the conflict has considerably reinforced distrust and hostile attitudes between the parties. One main facet of this is that the Armenian side, as is clear from Baibourtian's statement above, sees the present and the future in the historical perspective of being encircled in a Turkic world which has potential and actual genocidal intentions over Armenia and may be intending to pursue these in the future. In the words of one analyst,

the Armenian side is negotiating with the past and not the future. So far, the events of 1915 dominate Armenian consciousness and the entire peace talk process Armenian fears and apprehensions are rooted in this past experience. It is still characteristic for Armenians to be convinced that all things Turkic (which includes Azerbaijan) are to blame for the Armenian national tragedy ... for them, Karabakh is a continuation of the events of $1915 .^{464}$

\footnotetext{
462 Interview with Zulfugarov, Baku, October 1998.

${ }^{463}$ Interview with Baibourtian, Yerevan, October 1998

${ }^{464}$ Yunusov, ”The Status of Nagorno-Karabakh”, op. cit. [454], p. 3.
} 
An active process is under way in both republics to radicalize public opinion and deepen mistrust; a process which includes indoctrination of school children against the 'enemy'. On the societal level, there is extremely little contact between Azeris and Armenians; a visit of a handful of Azeri journalists to Yerevan in 1998 was a break-through in this sense; the journalists did not at all find Armenia to resemble the stereotypes given in Azerbaijan and reported this; the same happened when Armenian journalists as a response visited Baku. On the whole, however, confrontational attitudes and the advocacy of military solutions remain strong. In the words of Libaridian,

each party has impugned the worst intentions on the other, and each party has more often than not behaved in a manner justifying the other's worst fears. This is more than mistrust at work: it is the dehumanization of the adversary that makes even dialogue, let alone serious negotiations, difficult. ${ }^{465}$

Fifth, the continued ambiguous Russian role in the region is a main impediment to a solution. Practically all observers doubt whether Russia is actually interested in a solution to the NagornoKarabakh conflict, which would impede the use of 'divide and rule'-tactics on Russia's part. The important place Russia holds in the Minsk Group naturally increases the difficulties of solving the conflict, given the questionable character of Russia's intentions. The suspicions engendered by this circumstance are also salient: the suggestion that the November 1998 'common state'approach is a Russian approach, utilized in Abkhazia and Transdniestria as well as NagornoKarabakh, which would seek to prevent any long-term solution to these conflicts, is a clear example.

\section{Models of Solutions}

\section{A Return to the Status Quo Ante}

The first solution, attempting to bring back the status quo ante, is advocated by Azerbaijan. The main arguments for this solution is that the territorial integrity of independent states shall be respected, and the logic follows the principle (discussed in the legal aspects) that national minorities have the right to autonomy and to exercise their culture and religion, but not to secession and armed uprising. The main obstacle to such a solution, naturally, is the categorical Armenian refusal of this argument. The Armenians argue that they cannot live together with the Azerbaijani after the events in the war. Furthermore, they argue that the Karabakh Armenians do not recognize the legitimacy of the Azerbaijani government, and claim the right to complete selfdetermination. Thus it seems very unlikely that such a solution could be enforced in practice. The Armenians are by force of arms controlling Karabakh and its surrounding regions, that are left as deserted lands. Thus having achieved their war aims, it is inconceivable for them to give up their hard-won territory and accept Azerbaijani sovereignty. Such a solution can only be achieved through arms, as the Armenian population have shown their readiness to fight for what they consider their right. And in any case, usage of force against them would lead to a mass exodus to Armenia before any form of autonomy can be established. Hence it seems unlikely that Azerbaijan's full territorial integrity can ever be reestablished, at least by peaceful means, and unless the Armenians in Nagorno-Karabakh are forcibly evicted.

465 Libaridian, ”Time is on Neither Side”, p. 3. 
The second solution is the acceptance of the Karabakh Armenians' right to self-determination and their subsequent independence or annexation by Armenia. This solution would effectively put an end to the conflict provided Azerbaijan recognizes it. Furthermore it would fulfill the selfdetermination argument and confirm with the right of peoples and minorities to decide on their own future. This argument doubtlessly has many proponents in the West, particularly in minority rights organizations and the like, not to speak of the Armenian Diaspora. However this argument is not devoid of problems and contradictions. The most obvious objection to it is that it would actually recognize the use of force and ethnic cleansing in the alteration of internationally recognized borders. Given the present international atmosphere, it seems as if the perpetuation of the present situation, Nagorno Karabakh's secession from Azerbaijan-and the creation of an independent Karabakh and/or its annexation to Armenia — can be ruled out as a solution to the conflict. This is primarily due to Azerbaijan's categorical refusal but also because of the reigning general uneasiness concerning secession felt by all international actors, as has been outlined above. In particular, given the delicate geopolitics of the Caucasus as a whole, it is feared that granting independence to Nagorno Karabakh would have repercussions on the whole region's stability, leading to increasing tensions in Abkhazia, South Ossetia, and Chechnia, as well as within Azerbaijan itself, given the existence of a vocal Lezgin minority in the country, ${ }^{466}$ among others. Hence it would set a precedent for other irredentist movements in a clearer way than Bosnia, for example, did. The Bosnian Serbs, just like the Karabakh Armenians, have achieved most of their war aims. But the Dayton agreement does not acknowledge the use of force of the Serbs, and prevents, at least in theory, the partition of Bosnia-Herzegovina. Thus an international acceptance of the independence of Karabakh or of its unification with Armenia would be a doubtful act in terms of international law.

Another problem, is that the Azeris, not without a point, see that militarily things can not be any worse than they are, and that if time is in their favour. As the country is expecting billions of petrodollars to start flowing in within the next few years, that would enable it to build up a strong and well-organized army. In turn, this would mean that Azerbaijan would have an increased leverage on the Karabakh Armenians and would be in a position to impose a solution on the other side. The Azeris are actually silently voicing their belief that in the long run, the tiny Karabakh Armenians, or even the resource-poor Armenian republic, will not pose a military obstacle to the more numerous Azeris in reconquering Karabakh. Another point in this context is that the Azeri refugees are growing increasingly restless in their camps. A recent analysis of their condition shows that tension is rising among the refugees, who intend to take the matter in their own hands if nothing is done to give them back their lands. As one of the camp leaders stated, there are one million refugees; out of these it would be easy to collect over 150'000 fighters, who are doubtlessly frustrated enough to take such action. Needless to say, the tensions among the refugees is of great concern to the Azerbaijani government, recalling that the two previous governments where both toppled because of their failure to turn the tide of the war.

\footnotetext{
${ }^{466}$ Elizabeth Fuller, “Caucasus: The Lezgin Campaign for Autonomy”, in RFE / RL Research Report, vol. 1 no. 41, 16 October 1992; Anna Matveeva and Clem McCarthy, The Lezgins: A Situation Assessment, International Alert Report, May 1997.
} 
Furthermore, the independence of Karabakh would actualize the question of the Lachin corridor and the Kelbajar region. It is doubtful if the Armenians would let go of Lachin even if Azerbaijan would put it as a condition for the independence of the region. The Lachin issue is in fact a major point of contention which may prove to be the most difficult nut to crack in the whole conflict. For whatever the solution of the conflict will be, Lachin remains crucial to both parties. For the Azeris, it is the principle of their territorial integrity that is on stake; whereas they could let Karabakh go and save their face, as the region is not inhabited by Azeris in any case, the Lachin area was homogeneously Azeri and giving it up would be a deep humiliation. Similarly, the Armenians would argue that without the land connection of Karabakh to Armenia through Lachin, there can never be any secure position for the Karabakh Armenians. If Azerbaijan was allowed to reassert control over Lachin, Karabakh would constantly remain vulnerable to the wishes of Baku; there would always be a leverage on them.

Quite apart from these considerations, the feasibility of an independent state of Nagorno Karabakh can be questioned. As regards the territory of the enclave, it is debated. Although the natural solution would be to use the borders of the NKAO, the Armenians demand the incorporation of the Shaumianovsk district to the North of the enclave, as well as the Lachin corridor, which are both technically parts of Azerbaijan proper. However, it seems as if certain standards of democratic governance are feasible in Nagorno-Karabakh. The presidential elections of November 1996 of the enclave, although condemned by the OSCE as they were an attempt to legitimize the independence of Karabakh, were considered to be free and fair by international observers. ${ }^{467}$ However, the problem lies in the Azeri minority of the enclave, which amounted to almost a quarter of the population in 1988. If these people are considered to be a part of the enclave's population, then a popular consensus among the inhabitants of Nagorno Karabakh on the aim of sovereignty ceases to exist, as an important section of the population would be categorically opposed to independence. There is also considerable doubt as regards the treatment of the Azeris in an Armenian state. This circumstance could actually be termed an issue within an issue; in this sense one can speak of the existence of an Azeri minority in Nagorno Karabakh whose right need to be protected. This minority would be likely to challenge Armenian rule in the enclave, supported by the Azerbaijani government. Hence it seems as if the establishment of a new political entity would threaten the primary political rights of a minority within this entity; furthermore this entails that the prospects for political consensus within the new boundaries are doubtful. It is not to be excluded, either, that the entity has aggressive designs on its neighbourthe occupation of Azeri territory beyond the NKAO's borders testify to this. These facts put together tend to lend credence to the argument that the secession of Nagorno Karabakh is not a viable solution to the conflict.

As we see, there is a deadlock. For both sides, crucial interests are at stake, and there seems to be little room for a compromise. This fact is also related to the contentious issue being the very question of Karabakh's territorial affiliation. Hence there is no applicable precedent or resolution mechanism in the history of international politics that can easily be adopted to the Nagorno

\footnotetext{
${ }^{467}$ See Elizabeth Fuller, "When Should Unrecognized States Hold Elections?”, OMRI Analytical Brief, 27 November 1996.
} 
Karabakh conflict. Clearly, any solution that is acceptable to both parties must be plowing new ground in the field of conflict resolution.

\section{A Re-Negotiated Autonomy}

The first point that comes to mind is whether it is possible to re-negotiate Nagorno Karabakh's autonomy within Azerbaijan, possibly coupled with international guarantees. As a concept, Autonomy solutions are advantageous as the nature and degree of self-rule can be tailor-made to fit the needs and wishes of a particular ethnic minority, and the particularities of their territory. Hence different profiles of political power distribution can be articulated. ${ }^{468}$ It may include issues such as territory, language, natural resources, legal systems, taxation, etc. A theoretical scheme involving eight dimensions and three degrees of autonomy has been developed by researchers such as Nordquist. This framework can be briefly sketched as follows:

\begin{tabular}{|c|c|c|c|}
\hline & Low & MEDIUM & HIGH \\
\hline Security & Central police force & Central force, locally recruited & $\begin{array}{l}\text { Locally recruited and } \\
\text { organized force }\end{array}$ \\
\hline $\begin{array}{l}\text { Language/ } \\
\text { Cultural rights }\end{array}$ & $\begin{array}{l}\text { Basic education, culture, } \\
\text { religion }\end{array}$ & $\begin{array}{l}\text { Complete educational system, } \\
\text { administrative matters }\end{array}$ & $\begin{array}{l}\text { Local language is official } \\
\text { language }\end{array}$ \\
\hline $\begin{array}{l}\text { Natural } \\
\text { Resources }\end{array}$ & Central control & $\begin{array}{l}\text { Mutual veto right, projects with } \\
\text { central economic Support }\end{array}$ & $\begin{array}{l}\text { Local control, no central } \\
\text { economic support }\end{array}$ \\
\hline $\begin{array}{l}\text { International } \\
\text { relations }\end{array}$ & $\begin{array}{l}\text { No right to international } \\
\text { agreements }\end{array}$ & $\begin{array}{l}\text { Right to selective application of } \\
\text { international agreements, } \\
\text { initiate within certain autonomy }\end{array}$ & $\begin{array}{l}\text { Right to conclude inter- } \\
\text { national agreements in all } \\
\text { spheres of autonomy }\end{array}$ \\
\hline Economy & $\begin{array}{l}\text { Central taxes, central } \\
\text { allocation; local budget } \\
\text { share of central budget; } \\
\text { development centrally } \\
\text { controlled }\end{array}$ & $\begin{array}{l}\text { Tax paid locally, transfer-red to } \\
\text { central power; adaptation of } \\
\text { budget to local conditions; } \\
\text { central support for local } \\
\text { development. }\end{array}$ & $\begin{array}{l}\text { Veto right on central taxes; } \\
\text { all taxes paid to local auth- } \\
\text { ority. Right to allocate } \\
\text { locally collected tax. }\end{array}$ \\
\hline Executive & $\begin{array}{l}\text { Governor nominated and } \\
\text { appointed centrally; central } \\
\text { authorities have full admi- } \\
\text { nistrative responsibility }\end{array}$ & $\begin{array}{l}\text { Governor nominated from local } \\
\text { list; Central support and control } \\
\text { over administration, local } \\
\text { implementation }\end{array}$ & $\begin{array}{l}\text { Governor locally nominated } \\
\text { and appointed. Local } \\
\text { implementation of all } \\
\text { regulations. }\end{array}$ \\
\hline Legislation & $\begin{array}{l}\text { Central legislation without } \\
\text { local veto; right to proposes } \\
\text { only. }\end{array}$ & $\begin{array}{l}\text { Right to legislation in some } \\
\text { areas, and to amend central } \\
\text { legislation. }\end{array}$ & $\begin{array}{l}\text { Local legislation in all areas } \\
\text { of autonomy, veto of central } \\
\text { legislation. }\end{array}$ \\
\hline Judiciary & $\begin{array}{l}\text { Judges and courts centrally } \\
\text { appointed, right to propose } \\
\text { members of court }\end{array}$ & $\begin{array}{l}\text { Judges and courts centrally } \\
\text { appointed but local veto; central } \\
\text { nomination but local } \\
\text { appointment }\end{array}$ & $\begin{array}{l}\text { Judges and courts locally } \\
\text { nominated and appointed, } \\
\text { veto right of central deci- } \\
\text { sions regarding autonomy. }\end{array}$ \\
\hline
\end{tabular}

Source: Nordquist, Autonomy as Conflict Resolution, Appendix III, pp. 33-35.

This scheme shows the possibility of allocating different degrees of autonomy for different aspects of autonomy. Naturally, if the left-hand column is consistently applied, there is not much autonomy left. Similarly, if the right-hand column is followed, the situation will be very close to independence. With the help of the three-leveled and multi-dimensional framework outlined, it is feasible to reach a negotiated compromise suiting the particular needs of the Karabakh Armenians. Keeping in mind the Azerbaijani position of according Nagorno Karabakh the highest form of autonomy short of independence, it seems à priori possible to achieve a compromise

\footnotetext{
${ }^{468}$ Kjell-Åke Nordquist, Autonomy as Conflict Resolution-Experiences from Self-Government after Internal Armed Conflict, Draft Version (January 1997), Uppsala University Department of Peace and Conflict Research., p. 14
} 
which would satisfy the Karabakh Armenians as well. Nevertheless, the ambiguities in the Azerbaijani stance on the subject need to be clarified for this assumption to be correct. The reluctance of the Azerbaijani side to do this may be the result of a mixture of a genuine inability to formulate a proposal, coupled with an actual intention to refrain from any clarification on the matter.

Without anticipating the results of such negotiations, it is necessary to analyze which aspects of autonomy would be most important for Nagorno Karabakh. It is likely that the Armenians will focus on Security, Language/Cultural Rights, Executive, Legislation, and International Relations; and accord medium importance to Economy, Natural Resources, and Judiciary.

A high degree of autonomy in international relations would allow Nagorno Karabakh to enter into agreements with Armenia, which it considers essential for its survival. One could imagine a guarantor role for Armenia, similar to the ones exercised by Turkey, Greece and Britain in Cyprus. Azerbaijan would perhaps retain a veto right over such agreements. The question is whether an Azerbaijani veto power would be acceptable for the Armenians given the importance they attach to their link with Armenia. Secondly, in terms of language, Armenian would be the official language of Nagorno Karabakh as it was in the Soviet era. Third, in terms of security, a high degree of autonomy would enable Nagorno Karabakh to locally and independently organize its police forces. In this context, it is likely that Azerbaijan would see the need to keep some form of control over the security forces of Karabakh, in order to prevent the fragmentation of the armed forces of the republic - something which could engender further conflict. The existence of two separately controlled military structures antagonistic to each other in a country is definitely not desirable. As demilitarization may not be a politically feasible solution, a link in the security field is warranted. A medium/high degree seems to be a possible compromise, where Nagorno Karabakh would not be stripped of its ability to self-defense but where Azerbaijan would still keep an influence over the Karabakh Armenian military and paramilitary formations. Fourth, a locally appointed governor/president, as well as local legislation with a central veto right may satisfy the concerns of each side. These provisions would enable Nagorno Karabakh to exercise a high degree of self-rule, including the right to conclude agreements with Armenia, while the territory technically remains within Azerbaijan. The Azerbaijani central government would keep a veto right on certain issues, while having an initiative regarding natural resources, development, and economical issues. The Azerbaijani veto right will certainly be opposed by the Armenian side. But unless Azerbaijan retains this right, Nagorno Karabakh would actually be de facto independent as its self-determination would be absolute. Hence without a veto right, one can argue that the solution would not be one of autonomy but rather de facto secession. Doubtlessly, this would result in a singularly high level of self-rule for Nagorno Karabakh. Nevertheless, this compromise might be the one that satisfies the interests of both parties to the largest extent. Important ambiguities and obstacles to its implementation persist, which can only be worked out at the negotiating table. Assessing them here would be speculative and go beyond the scope of this study.

The Karabakh Armenians' primary concern is security and self-rule, as well as relations with Armenia. The provisions listed above, if coupled with international guarantees, seem to satisfy these concerns. As far as Azerbaijan is concerned, its main concern is to prevent the fragmentation of its territory. This arrangement, although certainly stripping the Baku government 
of direct control over Karabakh, would safeguard the territorial integrity of the country, and ensure Azerbaijani presence in the enclave.

In the present case, and to use Karl Deutsch' terminology, the involved countries are far from, and are not evolving towards a security community, where states expect no armed conflict with other members of the international system. ${ }^{469}$ Rather, they are in a situation of a security dilemma, where actors, while trying to create security actually end up undermining their own security. In practice, defensive actions by a state to improve its security are interpreted as hostile by the counterpart, which takes countermeasures, etc. ${ }^{470}$ The situation in this sense is by no means unique in international relations. It presents distinctive similarities with the situation in Cyprus, Bosnia-Herzegovina, and the Israeli-occupied territories in particular. Like the Turkish Cypriots feel the need of a Turkish guarantor role for their security, the Armenians in Karabakh have a similar orientation towards Armenia, both communities actually desiring partition and unification with their motherland. Greece and Azerbaijan, and the Greek Cypriots and the Azeri minority of Nagorno Karabakh, equally vehemently oppose this guarantor role and see it as unacceptable. Naturally, the case is more articulated in Cyprus but the similarities are striking. In the TurkishGreek context, the events of the first quarter of this century come to mind as a precedentalthough not an ideal nor a desirable one. The minorities question, potentially explosive, was resolved through exchange of populations. Although such a solution indeed proved stabilizing in the long run, virtually pulling up the roots of a conflict, it is highly questionable in terms of ethics and morality. Furthermore, the practical implementation of a population exchange may not be possible in the case of Nagorno Karabakh.

The prospects of a re-negotiated autonomy are difficult to assess. The lack of mutual confidence and trust is a main obstacle for the future of a re-negotiated autonomy. In such a situation, in fact in every situation except secession, the two enemies are forced to cooperate within the structure of a single state. Autonomy decreases interaction and presumably thereby the potential for tensions, but in the final analysis the difficulty remains to induce to cooperation two groups who do not actually want to cooperate. The feasibility of the suggestions listed above will become clear only if the parties agree to sit at the negotiating table. Indeed, bringing them to peaceful negotiations might be as difficult as reaching an agreement once negotiations have been started. Autonomy, then, despite the Soviet legacy remains one of the primary models of resolving the conflict. There are nevertheless other solutions that deserve to be mentioned.

In a discussion on autonomy, it should be noted that this solution to a large extent implies a territorial and legal separation along ethnic lines of the population of a state. Hence, the autonomous position of a minority may actually impair the inter-ethnic relations and dialogue between the two communities. It may isolate the groups from each other rather than to integrate them in a common state structure. Hence autonomy may increase the potential of further conflict in certain cases, as it may be understood as a first separation awaiting the eventual divorce. Thus while advocating autonomy as a solution to ethnic conflicts, one must also be aware of the dangers involved with this concept.

\footnotetext{
${ }^{469}$ See Karl W Deutsch, Political Community and the North Atlantic Area, New Jersey: Princeton University Press, 1957.

${ }^{470}$ See Barry Buzan, People, States, and Fear: an Agenda for International Security Studies in the Post-Cold War Era, London: Harvester Wheatsheaf, 1991.
} 


\section{A Territorial Swap?}

A glance at the settlement patterns before 1988 shows that Armenians were living in Armenia and in Nagorno Karabakh; Azeris lived in mainland Azerbaijan and in Nakhjivan, but also in substantial numbers in Zangezur, the thin strip of land separating Nakhjivan from Azerbaijan.

This pattern is naturally highly conflict-prone even would the Karabakh issue be settled; Azerbaijan would still be divided into two territorial units. In this perspective, a lasting solution to the conflict needs to take into consideration not only the status of Nagorno Karabakh but the communications between all separated territories. As the Armenians argue that the Lachin corridor is a necessity for the security of Karabakh, one could imagine a mutual boundary change whereby Armenia is granted Karabakh and Lachin, thus establishing a land connection between the two entities; Azerbaijan would in compensation receive a land corridor to Nakhjivan, through Zangezur. Such a solution has the advantage of eliminating many potential future conflicts that may erupt due to the problems of communication between Armenia and Karabakh or between Azerbaijan and Nakhjivan.

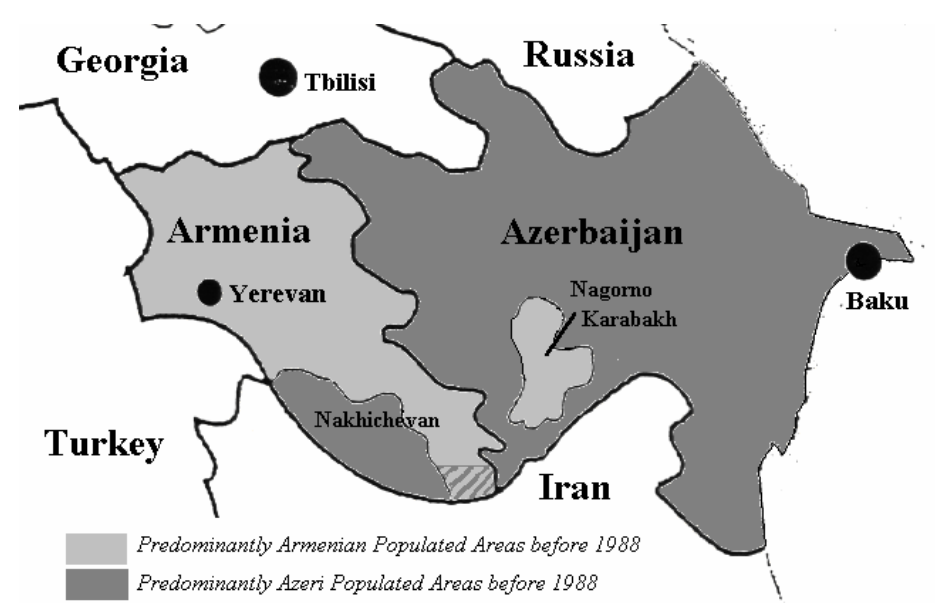

Figure Error! Unknown switch argument.: The Population

The main obstacle to this solution-which has actually been advanced, among others by Turkey's current Prime Minister Bülent Ecevit-is that it is unlikely to be accepted by either side. The Azeris, as stated above, are very reluctant to renounce sovereignty over Nagorno Karabakh. Even more, they categorically refuse to even discuss yielding sovereignty over the Lachin corridor, as it was homogeneously Azeri-populated before 1988 and was a part of the Azerbaijani republic itself, not of the NKAO. Hence there is reason to believe that even given the land gain of Zangezur, the Azeri side would be unlikely to accept such a solution. The Armenians would certainly appreciate to have Nagorno Karabakh and the Lachin corridor annexed to itself. However the price they would have to pay for this would be their border with Iran, which indeed has proven to be a life-line for the country. Without this border, Armenia would be landlocked between hostile Azerbaijan and Turkey, and potentially hostile Georgia. Hence Armenia is even less likely than Azerbaijan to accept this solution. For this reason, such a territorial swap is unlikely to be translated into practice although it might actually in the long term be the most durable solution to the ArmenianAzerbaijani conflict. 


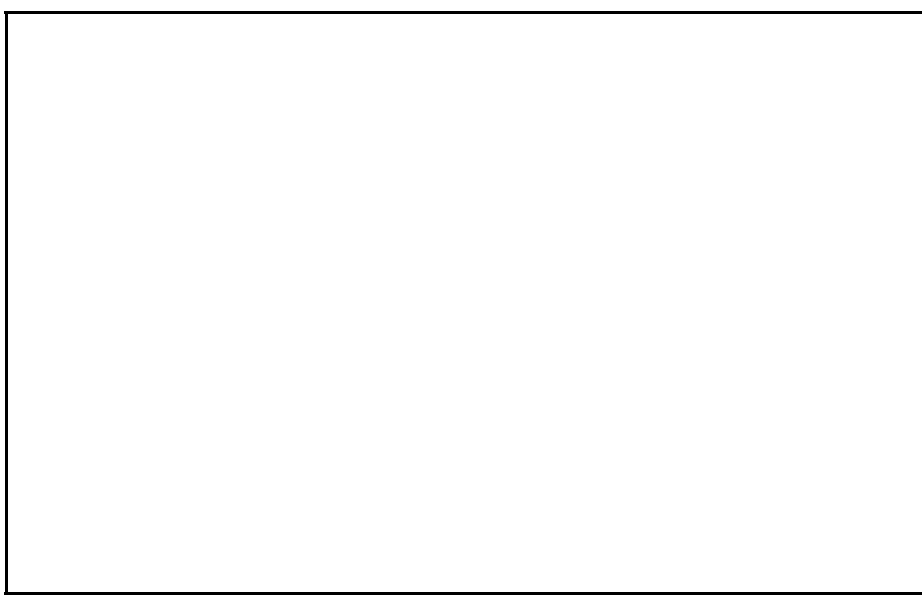

Figure Error! Unknown switch argument.: A Suggestion to a Territorial Swap

However, a possible although quite unique solution — and bearing in mind the unique conditions of the conflict there must be unique solutions-would be to put this corridor under nominal Azerbaijani jurisdiction but under international control, guaranteeing Armenia full rights to continue its relations with Iran through this route. Simultaneously, a similar arrangement could be done with regard to the Lachin corridor. Thus we would have a situation where the respective ethnic territories are linked, but where international presence would ensure to stability and durability of the settlement.

This solution might seem far-fetched at first sight, but the more one looks at it the more it is interesting - by default, as other more conventional suggestions fail. Most other solutions would have the potential to lead to renewed disputes in the future. However, a territorial swap is an alternative which presents a compromise where both parties have something to gain; and most importantly it has the potential to prevent, or at least decrease the risk of future irredentism. Any observer of the contemporary Azerbaijani society would testify that among the population, there is a significant frustration and feeling of the country's alienation by the world community. Moreover, there is a strong revanchist atmosphere, comparable to the French attitude towards Germany before the first world war. If the conflict is resolved in a way that is not perceived as satisfactory by the Azeris, then the chances for peace to survive are low. Thus if a durable peace is to be established, the solution must be one that calms the tensions between the populations rather than to exacerbate them-the solution must be legitimate for all parties.

\section{Joint Sovereignty}

A variant which seeks to further the same goal-communication between Armenia and Karabakh, and between Azerbaijan and Nakhjivan-without resorting to substantial border alterations, has been put forward by the former US special negotiator on Karabakh, John J. Maresca. ${ }^{471}$ Maresca' proposal can be summarized in a few key points:

- Nagorno Karabakh would be reconstituted as the Republic of Nagorno Karabakh, a self-governing legal entity within and freely associated with Azerbaijan.

- All refugees would be permitted to return to their homes.

- All of Armenia and Azerbaijan would be a free trade area, and the two states would agree on mutual transit rights across each other's territory.

- The settlement would be guaranteed by the CSCE and the UN Security Council, and US-led international efforts should invest in reconstruction of the area and the construction of road connections between Azerbaijan and Nakhjivan, and between Armenia and Karabakh.

\footnotetext{
${ }^{471}$ See John J. Maresca, War in the Caucasus: A Proposal for Settlement of the Conflict over NagornoKarabakh, Special Report, United States Institute of Peace, July 1994.
} 
This proposal presents a very comprehensive and far-reaching solution to the conflict. However, it requires a certain degree of mutual confidence and trust, which is totally absent on the ground, and can hardly be imposed by outside powers. The United States can certainly ensure the compliance of the Azeri and Armenian governments. But it is a totally different issue to prevent the renewed violence which would be a likely corollary of the return of refugees. The rift between the two communities is such that it is unrealistic to expect Armenians and Azeris to coexist peacefully in the near future. Forcing the populations to live together would likely backfire into new hostilities; hence a transitional period is necessary, where mechanisms such as confidence-building measures are implemented. Furthermore, the 'free association' of Nagorno Karabakh to Azerbaijan is likely to be interpreted in Baku as a capitulation and therefore not acceptable. From a larger perspective, the elements of Maresca's proposal dictate a kind of confederal relation between Armenia and Azerbaijan. At the very least, the governments of the two states must be in contact and close cooperation to ensure the implementation of the agreement. This is not a realistic assumption at this time either, notably as mutual transit rights and the like would considerably decrease the sovereignty of the two states. The fact that mutual suspicion remains and is likely to exist in the foreseeable future points to the risk of renewed conflict and revisionism in both camps. This discussion in the Nagorno Karabakh framework also illustrates the difficulties of implementing the Dayton peace accord in Bosnia-Herzegovina. The experiences in Bosnia may actually be valuable for a solution of the Karabakh conflict, in case the stability in the Balkans is preserved.

This said, certain elements of the plan are valuable and need to be further developed: the idea of a free trade zone and of international aid regarding communications and reconstruction may be crucial as corollaries to any solution of the conflict.

One point which deserves special attention is the Shusha-Lachin corridor which separates Karabakh from Armenia. As has been discussed above, both parties are intransigent on this issue for historical and security reasons. In many respects, this issue can be termed a 'key' to the conflict. For example, the Azeris see Armenian concessions on Lachin as a prerequisite for a solution. To solve this seemingly intractable problem, a regime of joint or international sovereignty has been advocated by certain scholars. ${ }^{472}$ One could imagine a solution where the Lachin corridor would remain under de iure Azerbaijani sovereignty but controlled jointly by Azerbaijani and Karabakh Armenian forces, under the supervision of international peace-keepers. Such a solution would satisfy the need for security for the Karabakh Armenians, while it would safeguard Azerbaijan's sovereignty over the area. The town of Shusha could be the subject to a reverse arrangement: Being situated within Nagorno Karabakh, it would remain under nominal Karabakh jurisdiction, but be under joint control. Hence irrespective of the form of the eventual solution, two types of territories with different status should be defined: (1) Nagorno Karabakh itself, and (2) territories to be placed under joint control and sovereignty. ${ }^{473}$ This solution, if adopted, would solve one of the tightest knots in this conflict. However, for it to be successful, the Azerbaijani side needs to be made aware of the necessity to grant this concession to the Armenians despite adverse effects on its sovereignty over its land.

\footnotetext{
${ }^{472}$ See Anatoly N. Yamskov, “Joint Control over Key Territories in Nagorno Karabakh”, in Security Dialogue, vol. 27, no. 1, 1996, pp. 95-98.

${ }^{473}$ ibid., p. 97.
} 


\section{Other Suggestions and Models}

Besides these principal models of resolution, there have been a number of less successful suggestions for the resolution of the Nagorno-Karabakh conflict. For example, a solution basing on the one in Cyprus 1960-63 has been advocated, whereby Karabakh Armenians would be guaranteed an influence in the decision-making of Azerbaijan. However this suggestions fails to recognize the territorial character of the conflict. Another variant has been to advocate a solution of the Chechen type, whereby the final status of Nagorno-Karabakh would be deferred for a number of years pending a normalization of the relations between the peoples and the return of refugees. This suggestion has failed to gain popularity for the same reason as the 'phased' approach to resolution was rejected: there would be no guarantee for the sovereignty of NagornoKarabakh. Moreover Azerbaijan fears that such a solution, much as has been the case in Chechnia, would lead to the perception of Azerbaijan having de facto recognized the independence of Nagorno-Karabakh.

Another proposal that has been made recently is to grant Nagorno-Karabakh a status of neutrality coupled with international guarantees. According to the plan, presented by Nikolay Hovhannisyan of the Armenian Academy of Sciences, the NKAO would be renamed as the Nagorno-Karabakh Neutral Territory (NKNT), which would be guaranteed by the UN security council, Armenia and Azerbaijan. NKNT would have its own constitution, and be governed by locally elected legislative and executive bodies, under the supervision of a plenipotentiary spokesman of the UN security council, approved by Armenia and Azerbaijan, whose main function would be to watch the neutrality of the NKNT. The territory would have its own military and police forces, foreign representation, and its own flag, coat of arms, etc. Moreover, according to the suggestion, the Lachin corridor would be associated with the NKNT. ${ }^{474}$ The problem with this solution, of course, is that it is simply a covert form of granting Nagorno-Karabakh total independence with the restriction of its political neutrality. It would have all assets and symbols of a state except in name, and moreover would practically include the Lachin corridor. In other words, it is a solution which suits the interests of the Armenian side almost completely, rejecting the territorial integrity of Azerbaijan. Therefore it remains unacceptable to the Azerbaijani side, as it would indeed create 'horizontal relations' between Stepanakert and Baku. However it is important in that it is an example of the attempts to move away from value-laden terms as statehood and independence on the Armenian side; and hence a step in the direction of a compromise. The idea may in principle be used and explored in further detail, something which the author is fully aware of; ${ }^{475}$ however in its present form it is not apt to be discussed as a blueprint.

The so-called Tatarstan model is asolution that has surprisingly enough not been treated to any significant extent. The Tatarstan model implies the creation of an 'associated state'; that is a state within a larger state. Tatarstan claims statehood and a enjoys a substantial degree of selfdetermination, verging on independence in the economic sphere, and pursues its international

\footnotetext{
474 See Nikolay Hovhannisyan, "Status of Neutrality to Nagorno-Karabakh”, Yerevan News, 20-26 November 1997. A longer discussion is found in Nikolay Hovhannisyan, ”Nagorno-Karabkhskiy Konflikt i Varianty evo Reshenya”, in Etnopoliticheskie Konflikty v Zakavkaze: Ikh Ictoku i Puti Reshenya, College Park: University of Maryland, 1997, pp. 92-121.

475 Ibid; author's conversations with Professor Hovhannisyan, October and December 1998, Yerevan and Venice.
} 
relations in a relatively independent manner (having opened 'representation offices' in over fifteen countries); however it acknowledges forming a part of the Russian Federation, subordinating to its institutions and delegating significant powers to Federal authorities. Indeed, this model seems to pose a constructive blueprint for negotiations. It does comply with the Azerbaijani position of offering Nagorno-Karabakh a 'highest' degree of autonomy; moreover it has the advantage of avoiding the use of the term 'autonomy' which is 'tainted' by the past from an Armenian perspective. Whereas a main controversy lies in the definition of the future relations between Stepanakert and Baku as 'horizontal' or 'vertical', the associated state model may be helpful in providing a 'diagonal' type of relations. Whatever the terms used, it is likely that a future solution will bear resemblance to the Tatarstan model, while accounting for the specific conditions and circumstances of the Nagorno-Karabakh 'conundrum'.

\section{Pillars of a Solution}

The final solution to the conflict is naturally dependent on the evolution of the positions of the parties and on the domestic and international pressures on the negotiators-should negotiations be undertaken, something which itself is by no means certain. Hence the applicability of theory is not absolute, as it is not scholars, immune from political considerations, but statesmen who in the end would be taking the decisions. Theories of conflict resolution are however helpful in providing mechanisms by which a solution can be reached, and models of possible solutions that the parties can consider. In this sense, the achievement of a compromise may be facilitated.

The solution to the conflict will in the end be determined by the evolution of what we may term the 'ripeness' of the conflict. Thus the outcome of the conflict may not necessarily be determined by a negotiated political solution but equally possibly by other solutions, such as war (conquest) or unilateral capitulation.

The intention of this study has not been to advocate one single model for the resolution of this conflict. Nevertheless, the overview has shown that certain key points are important and may be conceived as the pillars of any future agreement:

- The preservation of the territorial integrity of Azerbaijan and the respect of the right to selfdetermination of the Karabakh Armenians seem to be inescapable elements of any solution. For this purpose, a renegotiation of the autonomy of Nagorno Karabakh within and loosely associated with Azerbaijan seems to be the most feasible solution; however given the historical connotations of autonomy, it may be necessary to try to envisage less value-laden terminologies. In practice, however, the most feasible status of Nagorno-Karabakh is a high level of autonomy in the true sense of the word; this may take the shape of an agreement of an 'associated state' such as Tatarstan.As discussed above, the enclave would enjoy substantial privileges, on the verge of those enjoyed by independent states, in self-rule and international relations.

- The return of the formerly Azeri-populated territories neighbouring and surrounding the $\mathrm{NKAO}$, and the restoration of full Azerbaijani sovereignty over these areas is an equally crucial element of an agreement. This can be said also of the return of refugees to their former places of residence, although this is a potentially explosive issue, especially as regards Azeris with their home in Nagorno Karabakh.

- For the key territories of Shusha, Lachin, and Shaumianovsk/Agdere, joint or international control in at least a transitional phase is inevitable. This requires the presence of international 
peacekeeping forces which may also be instrumental in facilitating the return of refugees. The international community, as proposed by Maresca, ought to assist the construction of improved communications between Azerbaijan and Nakhjivan, and between Armenia and Karabakh.

- Besides the mainly political character of the conflict, the economic dimension of conflict resolution must not be ignored. The very existence of the just mentioned communications, and the right of Karabakh to conclude agreements with Armenia, necessitate the establishment of a free trade zone incorporating the two republics. In the ideal case, this would also include Georgia, South Ossetia and Abkhazia, thereby forming a South Caucasian free trade area which may be conducive to peace in the entire region. Such an arrangement is desirable as it in the long term reduces the importance of boundaries and state sovereignty-something which would be instrumental in decreasing the tensions between central governments and minorities. 


\section{9 \\ Nagorno-Karabakh in Eurasian Geopolitics}

The conflict over Nagorno-Karabakh has arguably de facto become a central defining factor in the emerging Eurasian strategic alignments that have been alluded to in earlier chapters. A credible case can be made that the zero-sum logic that governs the relationship between Azerbaijan and Armenia is what has enabled foreign actors to get a foothold in the Caucasus by supporting one state against the other, leading hence to the alignment of forces around the two parties to the conflict.

Anything that is seen as being in the interest of Azerbaijan is perceived as to the detriment of Armenia, and vice versa. This said, it is certain that both states have been forced to take part in various joint projects, typically large-scale transportation or development projects such as the Europe-Caucasus-Central Asia transport corridor project sponsored by the European Union. Whereas Azerbaijan does its best to minimize Armenian participation in all projects to which it is a party, this approach has only been partially successful. Generally speaking, however, the rules of the zero-sum game are widely applicable to the relations between the two countries. This is naturally most notable in the military balance; arms shipments from Russia to Armenia are perceived as a direct threat to Azerbaijan. Armenia would see any strengthening of TurkishAzerbaijani military cooperation in the same way; moreover Armenia would be forced to see the strengthening of Azerbaijan's finances and oil income to that country as a threat to its security as it would mean a possibility to acquire armament that would offset Armenia's military advantage over Azerbaijan. As a result the zero-sum game is applicable to economics as well; one of Azerbaijan's main political weapons against Armenia has been and remains the embargo of that country that Baku enforces together with Ankara. As a result any improvement of the Armenian economy is detrimental to Baku's relative position in the 'dyad'. The destabilizing consequences of this nature of the Armenian-Azerbaijani relationship are easy to imagine, especially with respect to the involvement of regional powers in the Caucasus. Azerbaijan's foreign policy aims are first, to export its oil through a western pipeline that passes neither Russia nor Iran; second, to build up its economy and military to achieve a return of Nagorno-Karabakh and its adjacent areas through coercive diplomacy and, if that fails, military means; and third, to become the hub of the Caucasus and Central Asia, being the focal point that links Central Asia to the Caucasus, Turkey, and Europe. Hence Azerbaijan's primary ally is and will remain Turkey; however by virtue of its strategic importance Azerbaijan hopes to develop its economic, political, and military links to the US. Currently Azerbaijan seems to be relatively successful in developing its importance in world politics. By contrast, Armenia has had no choice but to enter into an alliance with Russia and Iran, both powers that desire to prevent what Azerbaijan seeks to achieve, namely increased Turkish and American influence and an East-West corridor that will decrease their relative importance. As 
a result Armenia, which in the early 1990s managed the wonder of simultaneously keeping good relations with Russia, Iran as well as the US, now faces the consequences of allying increasingly openly with Russia and Iran: its relationship with the US is bound to lose some of its initial glow. The US increased interest in Azerbaijan, and the US criticism directed towards Armenia as regards the Nagorno-Karabakh question testify to this.

\section{Caucasian Fear Perceptions}

Generally speaking, the three Caucasian states face very different security predicaments and foreign policy orientations that are conditioned by their history and geography as well as plain Realpolitik. It is important to note that two of the states saw a regional power as incomparably more threatening to its respective national security than the others: For Georgia, Russia was and remains a direct threat to its sovereignty by manipulating internal divisions between the Georgian government and its autonomous regions, and in fact putting into question Georgia's existence as truly independent state; by contrast, Iran and Turkey were seen as incomparably less threatening to Georgia's national security. For Armenia, the chief threat was Turkey, initially more for historical than actual reasons; of course Turkey's siding with Azerbaijan increased threat perceptions. Armenia actually saw Turkey not only as a threat to its national security, but in a sense also as a threat to the survival of the Armenian nation, due to the Armenian perception of Turkey as a state with genocidal intentions. Whereas this perception was grossly exaggerated and even inherently mistaken, the perception itself is important as perceptions of reality, and not reality, controls policy. The threat emanating from Turkey was seen as so strong that Armenia actively cultivated security relations with both other major powers, chiefly Russia but also Iran and enlisted forces in America to decry Turkey's intentions.

Azerbaijan's situation was actually even more complicated: it saw both Iran and Russia as threats to its security, and could rely only on Turkey to support it—a major problem here being that Azerbaijan is cut off from Nakhjivan by Armenian territory and does therefore not have a continuous land connection to Turkey. Azerbaijan hence feels squeezed between three hostile states: Iran, Russia, and Armenia, all of which are in a position to threaten Azerbaijan's security both by military means and by preventing Azerbaijan from bringing its oil to the market. Iran, as viewed in chapter 8, does not desire an oil-rich Azerbaijan on its northern border; Russia would consider an independently acting and wealthy Azerbaijan as an impediment to its control over the South Caucasus; finally Armenia's stance needs no explanation. From this perspective, it becomes clear how desperate Azerbaijan is to establish military links with a foreign state, the only realistic option at present being Turkey. The discovery of Russia presenting Armenia with an entire arsenal, as mentioned in chapter 10, increased Azerbaijani fears; nevertheless the announcements in late 1998 of the deployment of S-300 missiles and upgraded MiG-29 jets in Armenia created an acute sense of insecurity in Baku, which resulted in the sensational demand for US military bases made by presidential adviser Gulizade in early 1999.

The situation in the Caucasus hence forms an extremely unstable security complex, in which two states exist in a 'no war, no peace' situation that is currently characterized by unsuccessful negotiations, an arms race, and increasing international involvement. Undoubtedly, an analysis of the security situation in the Caucasus must center on the Azerbaijani-Armenian relationship, which at present is by far the situation that has the highest potential to degenerate into a regional 
conflagration. Although the conflict between Georgia and Abkhazia is perhaps more unstable at present at the local level, it does not carry the same destructive potential, as it does not involve two independent states as primary actors. But moreover, regional and international powers do not have anything close to the same involvement in the conflict. Indeed, the main interests of foreign powers center around Azerbaijan and Armenia. They are, so to say, the center of the security complex.

As noted in earlier chapters, Turkey entered the Caucasus with great hopes in 1992, whereas Russia and Iran took on a reactive policy aimed primarily at preventing Turkish influence from expanding. Russia then seemed to pursue a relatively successful policy of reintegrating the South Caucasus into its sphere of influence; Iran was developing its relationship with Armenia but wary of Azerbaijan, and comparatively uninterested in Georgia. The US did not 'join the game' for real until 1997. Russia's policy of intervention was aimed mainly at reasserting control over recalcitrant Georgia and Azerbaijan; however, the consequences of its actions may turn out to have been the exact opposite. As Henry Hale has noted,

\begin{abstract}
In virtually every case where the USSR or Russia directly intervened ... this intervention galvanized support around the very nationalists that it sought to crush ... While [such] machinations produced immediate results consistent with Russian strategic aims ... the gains again proved to be superficial. Aliev ... has in fact become Russia's foremost political nemesis in the Caspian region, skillfully playing his restricted hand to bolster Azerbaijan's independence and economy ... Shevardnadze also has proved challenging for Russia, turning an even weaker hand into a winning one an positioning his tiny republic as the key link in efforts to export the anticipated riches of the Caspian basin to western markets Russia's misguided Machiavellism, then, has produced only superficial integration and has merely deepened a resentment that is undermining the chances for true integration in the long run. ${ }^{476}$
\end{abstract}

In fact, Shevardnadze and Aliyev have basically done all they have been able to and more to distance their countries from Russian control after consolidating their rule. In the mid-1990s, then one could observe two emerging triangular alignments — or perhaps better defined as states with convergent interests - among the six states of the security complex: The Moscow-YerevanTehran and Ankara-Tbilisi-Baku-triangles. At first sight there is a balance, with three states in each; but a closer look shows that the Russian-Iranian-Armenian alignment has a clear advantage over the Turkish-led alignment, by having two regional powers and one smaller state, instead of the opposite. Furthermore, while Georgia was politically in favour of the Turkish-led alignment, it was a country emerging from chaos and under heavy Russian influence. In this sense Turkey's initial failure to assert itself in the post-Soviet Caucasus is clearly understandable in terms of the balance — or unbalance — of forces that reigned. Turkish influence was comparatively limited in the Caucasus as Russia managed to be, in fact, a sort of arbiter of events in the region.

By 1999, a dramatic change in the balance of forces had occurred. This can be directly linked to the addition of the United States to as an actor in the security complex, joining Turkey's efforts to break through the Russian-Iranian resistance to western involvement. The consequence of American interest in the Caucasus has been a boost in Turkey's renewed efforts to assert its role in the region. Indeed, the US 'evened up' the balance among the now four regional powers to a situation with one major and one secondary (in global terms) power one each side—Russia and

\footnotetext{
${ }^{476}$ See Henry E. Hale, "Independence and Integration in the Caspian Basin”, in SAIS Review, vol. 19 no. 1 , 1999, p. 165-66.
} 
the US and Iran and Turkey respectively. Moreover, Israel's involvement in Azerbaijan and Georgia is striking at present, adding another powerful ally to the 'western' constellation. The Caucasus presents Israel with an opportunity to contain Iran; logically however, Syria is developing its relations with Armenia, Russia, and Iran. As concerns the Caucasus, the two most active players at present are Russia and Turkey. Russia has a military presence in Armenia, and despite the protests from Tbilisi, in Georgia. Turkey on the other hand is drawn into an ever tighter military cooperation with Azerbaijan, with the establishment of Turkish military presence in the country looking more likely than unlikely by early 1999 .

\section{The Retreating Hegemon}

Russian military encroachments in the Caucasus have tried to secure Russia's continued dominance over the region. However, it seems doubtful whether the actions conducted by Russia are bringing it any closer to this aim. As one analyst have noted, The prospects of Russian foreign policy are bleak. ... Russia has declined, is declining, and is likely to decline still further' ${ }^{477}$ In 1993-94, Russia temporarily seemed to succeed in reversing its declining influence in the "near abroad'. In Central Asia, no republic conducted an openly anti-Russian policy; Russia showed its ability to effectively intervene in the Transcaucasus to reassert control over Georgia and Azerbaijan, and Armenia has, in the words of one analyst, to committed 'the country to satellite status for the lifespan of the next generation'. ${ }^{478}$ Turkey's euphoria had given way to a seeming realization of the bitter truth of Russia's continuing hegemony, especially after the downfall of Elçibey; and the US was only acting through its oil companies in the Caspian. By early 1999 - that is five years later - the situation looks very different. While Russia can continue to rely upon its alliance with Armenia, Azerbaijan has resolutely adopted an anti-Russian rhetoric and has successfully resisted Russian attempts to base troops in the country. Instead, Baku is actively courting NATO and Turkey whom it sees as candidates to guarantee its security. The Russian border guards are scheduled to leave Georgia within a few months, and Tbilisi has joined Baku in decrying Russian intervention into their internal affairs. Both countries have played leading roles in an alignment with Ukraine, Moldova and possibly Uzbekistan that seeks to limit Russian influence over CIS countries, instead looking to the United States as their protector. Turkey, acting in tandem with an increasing American involvement in the region and with its military alliance with Israel, is making a renewed attempt —and a distinctively more credible one this time - to extend its influence in the Caucasus and Central Asia. Turkey and the US are now gradually beginning to challenge Russia's dominant role in the Caucasus by stepping up economic and political activity there, and by closer security and military cooperation with the states in the region. Uzbekistan, Azerbaijan and Georgia have all signaled that they will not renew their participation in the CIS mutual security treaty, and behave increasingly independently from Moscow. Rulers such as Heydar Aliyev, Eduard Shevardnadze and Islam Karimov now have a stable base to stand on, and control their respective countries to a degree which enables them to pursue independent foreign policies that put the interests of their own states before those of Russia's. And with Russia betting on a defensive alliance with Armenia and Iran, the interests of these states are increasingly differing from those of Russia. Increasing openness in the region and

\footnotetext{
477 See John Lloyd, ”A Superpower Humbled”, in Transitions, June 1998.

478 „Duma Ratifies Treaty on Russian Military Bases in Armenia”, Jamestown Monitor, 21 April 1997.
} 
strengthened interactions with the outside world have made it increasingly difficult for Russia to intervene as freely in the internal matters of these states; a hidden Russian hand might still be conceived of in explosions in Tbilisi or Tashkent, but on the whole, there is little Russia can do except to push hesitant states even further away from its orbit.

\section{Turkey: Second Attempt}

With regard to the geostrategy of the Caucasus, Turkey has established itself as one of the primary actors in the region. The very fact the Russia is worried of Turkey's military capabilities to such an extent is very illustrative of this fact. Turkey holds a crucial and leading role in the emerging alignment of pro-western, and in foreign policy matters proactive states which seek to create a mutually cooperative economic and political stability in the Caucasus: states which pursue geoeconomics while engaging in geopolitics, and reject the reactive geopolitical policies of Iran and Russia, which both have vowed to prevent Turkish and American influence in the region from expanding. The Turkish-American group currently encompasses Azerbaijan, Georgia, and Israel, with close ties to Jordan, Ukraine, Moldova and Uzbekistan. Turkey’s enemies, however, are lining up in an alignment led by Russia and Iran, especially Armenia and Syria but also Greece and Greek Cyprus.

The last few years have also seen the gradual improvement of Turkey's relations with Ukraine and Moldova. Turkey's interests in these countries are partly related to the Turkic minorities (the Gagauz in Moldova and the Crimean Tatars in Ukraine) but contain a heavy strategic component. Without wanting to alienate Russia with which Turkey has very important trade relationsanother proof of the web of interdependence of today's international relations-Ankara has become a tacit supporter of GUAM, the closer alliance of Georgia, Ukraine, Azerbaijan and Moldova: it is simply in line with Turkey's own interests to strengthen the independence and cooperation among these states.

One main interest of Turkey has been related to oil politics. Turkey early on declared it was interested in having Caspian oil flow to the Turkish Mediterranean port of Ceyhan; in the ideal situation, the re-opening of oil pipelines from Iraq and the export of Iranian oil through Turkey would make the country an energy metropolis. With regard to the energy resources of the Caspian sea, Turkey's policy goals have been summarized as follows:

1) Caspian oil would be a major source for the growing Turkish domestic consumption, and would have the advantage of decreasing dependence on Middle Eastern oil and Russian gas. Furthermore Turkey expected significant revenues from the transit of hydrocarbons headed to world markets, and an impetus to the economy through the construction of pipelines.

2) Caspian oil had a distinct strategic importance as its export through Turkey implied an increased standing in regional politics and an increased importance of Turkey for the west, which would be an asset in its quest for membership in the EU.

3) Domestic concerns played a key role insofar as the Çiller administration capitalized on the Baku-Ceyhan line as a tool for increased popularity. Indeed, Tansu Çiller made the pipeline 
issue one of the two main foreign policy goals of the country, the other being the customs union with the EU. ${ }^{479}$

Despite the strong backing of the Turkish, Azerbaijani and US governments for the Baku-Ceyhan pipeline project, oil companies involved in the Azerbaijan International Operating Company (AIOC) are reluctant to finance this pipeline given the current state of the oil market with prices hovering around \$10-12 a barrel and Iraq and Iran waiting for sanctions to be lifted. It seems as if substantial government subsidies from either the US or Turkey are necessary for the speedy realization of the Baku-Ceyhan project; indeed representatives of the oil companies complain that despite the heavy pressure on them to choose the Baku-Ceyhan line, not a cent has been promised in government support from any of the countries supporting it. In the long run, however, political considerations weigh heavily; on 29 October 1998, the 'Ankara declaration' supporting the BakuCeyhan route was signed by the presidents of Turkey, Azerbaijan, Georgia, Uzbekistan, and Kazakhstan as well as the US secretary of energy. ${ }^{480}$ It seems very unlikely at this point that oil companies will totally disregard this comparatively strong consensus among these states for Baku-Ceyhan. The most probable solution seems to be the postponement but eventual building of this pipeline. Nevertheless Turkey's political investments in the pipeline issue dictate that the country will not give up on this issue, but will use all tools at its disposal to realize the project.

Meanwhile Turkey's role is fundamental in the regional alignments that are developing; while Turkey has gone out of its way to ensure that it keeps at least working relations with the Russian Federation, which for the foreseeable future will remain an indispensable factor for anyone who wants to deal with the former Soviet Union's successor states. The second half of the 1990s have moreover brought a strengthened Turkish economic penetration of the Caucasus, as well as a more concerted, gradual and realistic approach concerning political and military relations with Azerbaijan and Georgia. Its alliance with Israel has been instrumental in increasing Turkey's selfconfidence and assertion in its relations with all its neighbours, including the three Caucasian states and Russia; indeed it has helped Turkey to increase its feeling of security in a volatile region, and enabled it to become a more independent actor in regional politics of the Balkans, the Middle East and the Caucasus. The recent stand-off with Syria and that country's compliance with Turkey's demands illustrate the point. Furthermore, the renewed rejection of Turkish application to full membership in the European Union in December 1997-and especially the tactless way in which it was made — signified that Europe holds a much lesser restraining role in the formulation of Turkish foreign policy. With the European door as good as closed, one can speak of a Turkish comeback to the Caucasus and Central Asia - this time to be taken distinctively more seriously. Especially since the fall of the Islamist-led government of Necmettin Erbakan in the Summer of 1997, Turkey's renewed interests in the Caspian region have become clear. In partnership with the United States, Turkey is set to be one of the major actors in the Caucasus and Central Asia for the foreseeable future.

\footnotetext{
479 See Meliha Altunisik, "Turkey’s attitude towards the Eurasian Oil: From Euphoria to Pragmatism”, in Marco Polo Magazine, nos. 4-5, 1998, pp. 24-25.

${ }^{480}$ See Turkish Press and RFE/RL Newsline, 30 October 1998.
} 


\section{Prospects}

Several analysts see the possibility of new war breaking out between Azerbaijan and Armenia within the next couple of years, although no one is really sure how such a war would break out. The fact, however, remains that low intensity conflict is continuing along the cease-fire line, which it should be mentioned is not monitored by any peace-keeping forces. The morale of the Azerbaijan side is increasing, whereas Armenia is confident that it can sustain the current situation, partly trusting Russian weapons and support but also because of its conviction-that is questionable - that 'Azeris can't fight'. If Azerbaijan manages to acquire enough weapons to challenge Armenia's current military superiority, it is not excluded that it will try to conquer back at least some of the occupied territories surrounding Nagorno-Karabakh. Statements from Baku increasingly follow this line of thinking, and seem unlikely to abate as negotiations flutter and frustration in the country increases. What is clear is that the increasing geopolitical importance of the Caucasian countries seems to work in a destabilizing way for the region. The increasingly heavy Russian military presence in Armenia can hardly escape a reaction from Turkey. Baku is actively lobbying circles in Ankara for the establishment of a Turkish or NATO military base in Azerbaijan. The prospect of an Armenia with Russian backing poised against Azerbaijan with Turkish backing indeed is a worrisome thought for the stability of the region. In fact, should a new conflict erupt between the belligerents, it is unlikely that either Russia or Turkey will be able to stay out of the developments due to their heavy links with their respective ally. Iran and the US are not as likely to intervene in the conflict, given that none of the two have committed themselves to either of the belligerents in a way close to Russia and Turkey. This circumstance underlines the argument that Russia and Turkey are the two main regional players in the geopolitics of the Nagorno-Karabakh conflict.

The last few paragraphs have presented a gloomy prospect for the establishment of durable peace in the Caucasus. With great power involvement in the politics of the region on the rise, geopolitics have taken a grip on conflict resolution that is unlikely to loosen in the near future; moreover the emerging alignments of small states involved in conflicts with larger regional and global powers are dangerous per se. However, there is at present no need to stress the similarities of the present Caucasian situation with the condition in Europe in 1914, that has been brought up by some observers. The links, economic and other, between the great powers are of a kind to mitigate the emergence of a large-scale war. Nevertheless, the situation in the Caucasus, and especially as surrounds the Nagorno-Karabakh conflict, deserve more attention and care than has been given to it. 


\section{0}

\section{Conclusions}

Among the conflicts that have raged in the Caucasus since 1988, the one over Nagorno Karabakh may stand in a distant second place as regards Human suffering and material destruction compared to the one in Chechnia. In the European perspective, it is also superseded by the war in Bosnia in terms of atrocities and international attention. But the conflict in Nagorno Karabakh has carried a geopolitical significance and a risk of degenerating into a regional conflagration that is arguably larger than any other conflict in post-Soviet Eurasia. Indeed, Nagorno Karabakh is the single conflict that has lead to threats actually being voiced of a 'Third World War'.

In the Caucasus, the Nagorno Karabakh conflict is the only conflict which involves two sovereign states as primary parties-Russia must be considered a secondary party to the conflict in Abkhazia, whereas Armenia can hardly be described as such in the case of Karabakh. The conflict thereby has the direct corollary of poising the military machines of two states against one another. But more importantly, the conflict has raged in the immediate vicinity of three states that moreover happen to be regional powers: Russia, Turkey, and Iran. At different points in time, both Turkey and Iran were seriously considering intervening in the conflict only to be reprimanded in very harsh terms by Russia; Russia, on the other hand, has kept interfering in the conflict as it saw fit to pursue its professed aim of regaining control and influence over the South Caucasus. In this context, it should be noted that despite the horrors involved for the victims of the Armenian-Azerbaijani war, the conflict was in a global perspective a comparatively small one, with an estimated death toll of less than 30'000 people. Horrific as this may be, it fades in comparison with the thirty thousand people that perished in single battles of the Iran-Iraq war, to name a recent example, or with the death toll of the Bosnian war, estimated at over quarter of a million people. The warfare in and around Karabakh in 1992-94 was after all a war with little sophisticated equipment; heavy arms were used rather sparingly simply due to their unavailability. Moreover the Armenian advances in Azerbaijan in the later stages of the war have been called 'armed tourism', rather than actual war, by foreign military commentators recorded by Thomas Goltz. Still, despite the comparatively limited scale of the war, it posed a significant challenge to the fragile peace and stability reigning between the three regional powers. Considering that since the war, Armenia has received weaponry from Russia to the value of over a billion American dollars, and that Azerbaijan is expected to receive oil revenues enabling it to acquire similar amounts, it is possible to imagine a nightmare scenario in which a renewed armed conflict between considerably strengthened adversaries would erupt. Such a clash would certainly have a stronger impact on Turkey as well as Iran than did the 1992-94 round. In addition, the Russian defeat in Chechnia implies that these two southern powers will be likely to be take Russian warnings less seriously than they would have in 1993, in particular in the case of Turkey which now claims to possess the second strongest army in the world after the United States-hence 
implying a stronger conventional military capacity than Russia, whose military credibility today mainly lies in its possession of nuclear weapons. Russia, in the words of Stephen Blank,

In other words, the Nagorno-Karabakh conflict still has a potential-increasing by the day as negotiations seem unlikely to break through the deadlock-to turn the Caucasus into what it was in the seventeenth and eighteenth centuries: a battleground between Russia, Turkey and Iran. Such scenarios may seem exaggerated in view of the increasing salience of economic interests that link the three powers into a certain level of interdependence. However, the specific elements of the conflict do give reason for worry. In the event of renewed warfare, it is not unlikely to assume that the scale of warfare will be such that Nakhjivan will be involved in it; and in this case Turkey is not likely to remain an outside observer. Indeed, the conflict still has a potential for internationalization incomparable to any other conflict in the Caucasus. Mediators from the OSCE, whose task has certainly not been an easy one, are in the meantime running out of options in their uphill struggle to find a solution to the conflict, adding desperation to despair. Especially disappointing was the fate in early 1998 of those circles in Armenia, led by former president TerPetrosyan, who adopted a conciliatory stance in the conflict. The events in Armenia clearly showed that the majority of political forces in Armenia are not ready for a compromise on Nagorno-Karabakh. The coup d'état against Levon Ter-Petrosyan is likely to reduce readiness to compromise not only of Armenian leaders, but will certainly influence the actions of Azerbaijani leaders, and perhaps also Georgian ones. Presidents Shevardnadze and Aliyev now certainly pay more attention to the danger of their respective radical opposition in their decisions regarding the respective conflicts. It is a fact that in both countries, as in Armenia before Kocharyan's advent to power, the regimes in power are relatively moderate whereas the opposition is generally less conciliatory. The Azerbaijani opposition, for example, refuses to grant more than cultural autonomy to Nagorno-Karabakh, something which will obviously never be accepted by the Armenian side.

On the political as well as societal level, the mutual 'dehumanization' of the enemy, as Gerard Libaridian termed it, continues to prevent even the initiation of confidence-building measures between the parties that could turn the downward spiral around, as has been the case in South Ossetia. There are virtually no economic, cultural, or other contacts between the two communities today, and the best term to describe the bilateral relations is the familiar zero-sum-game. Is then everything pointing toward disaster? In fact, Libaridian has rightly noted that the parties may already implicitly have solved the question of Nagorno-Karabakh's status. Whereas Azerbaijan is ready to accord the region a high level of autonomy, Armenia-including the Karabakh Armenians - have reluctantly renounced the goal of total independence and now view their future in a common state structure with Azerbaijan. These two positions are then in fact not diametrically opposite to each other as the situation seemed to be only a few years ago. Similarly, virtually all political forces in the two countries see the future of the Caucasus as a future in cooperation; as soon as the conflict has been solved—on one's own terms, of course - the professed aim of regional cooperation would accordingly be realized. The importance of this circumstance must not be underestimated; the crucial realization that the future is one in coexistence is present. Another important factor which would facilitate coexistence is that despite the policies of ethnic cleansing pursued primarily by the Armenian side, the civilian population has largely been spared — with a small number of exceptions - the massive and systematic 
atrocities characteristic of the wars in Bosnia or Rwanda. ${ }^{481}$ Despite the propaganda emanating from both sides, there have been no large-scale instances on either side that deserve the term genocidal activities. For example, when the Armenian forces concluded their invasion of Azeri lands South of Nagorno-Karabakh by attacking Zangilan, a narrow strip of territory between the front and the Iranian border was left under Azerbaijani control for the evacuation of refugees. ${ }^{482}$ The Armenian side was primarily interested in territory, not in annihilating the population, as did the Bosnian Serbs for example. The consequence of this is that the level of mutual hatred is susceptible to be overcome. In the words of MacFarlane and Minear, 'the absence of intense recrimination may enhance prospects for resettlement and reconstruction'. ${ }^{483}$

Given the existence of positive elements, solving the Nagorno-Karabakh conflict is then not an impossibility although it remains a very difficult task for the international community. The issues involved in the conflict are by themselves complicated enough, poising geography against demography, economy against ethnicity, territorial integrity against self-determination. Difficult as any solution may be to implement, the situation is worsened by the fact that outside factors keep influencing the relationship between the parties to it, in all but every case in a negative way. The emergence of regional alignments in Eurasia, with a stronger axis tying Armenia to Iran and Russia, and an emerging Azerbaijani-Turkish-Israeli alignment with tacit American support, implies a regional polarization which again impedes the resolution of the conflict by increasing the regional consequences of any change in the present South Caucasian Status Quo. As the area's strategic importance is increasing, partly for reasons related to the extraction and export of Caspian oil, this has a negative effect on conflict resolution. The parties feel an opportunity to play out great powers against each other for advantages; the result is the emergence of opposing alignments that is happening today. In particular, Russia's doubtful objectives in the region are a serious impediment to peace. The question, really, is if Russia wants the conflict to be solved in the near future. The recent 'common state' proposal originating in the Russian foreign ministry is an example of a move which ostensibly was carried out in the interests of peace but in practice led to a prolongation of the deadlock. Allegations that this scheme in fact has been used by Russia in several conflicts such as Abkhazia and Transdniestria in order to perpetuate Russian influence must be taken seriously; the Georgian government was so negatively inclined to the concept that it threatened to boycott in the OSCE any proposal of solving the Nagorno-Karabakh conflict through this principle. Whereas Russia is the main impediment to a lasting peace, other regional actors have hardly exerted a coherently positive influence. Iran's desire to keep Azerbaijan weak also implies that Tehran does not have an impartial attitude in the conflict; similarly Turkey's difficult relationship with Armenia also acts as an impediment. Last but not least, the wobbling attitude of the United States in the conflict has had negative repercussions, in particular due to the partisan politics in the US Congress. In this context the prospects of resolving the conflict in Nagorno-Karabakh become gloomy: There is a level of mistrust and suspicion between almost all parties involved either in the conflict or in the mediation process that directly impedes serious and constructive negotiations.

By early 1999, the Azeri refugees scattered in Azerbaijan are not likely to return to their homes anytime soon; neither are the Karabakh Armenians likely to gain international recognition for

\footnotetext{
481 As pointed out by MacFarlane and Minear, Humanitarian Action and Politics, op. cit. [427], p. 20.

482 See Goltz, Azerbaijan Diary, op. cit. [134].

${ }^{483}$ MacFarlane and Minear, Humanitarian Action and Politics, op. cit. [427], p. 20.
} 
their overshadowing ideal of being reunited with Armenia. The sad fact is that the ArmenianAzerbaijani conflict seems headed down a one-way street: that of non-settlement. In fact, save any breakthrough in negotiations which does not seem likely in the short term, the ArmenianAzerbaijani conflict may very well continue to destabilize the South Caucasus for a long time to come, much like the Arab-Israeli conflict has destabilized the Middle East for the last fifty years. 


\section{1}

\section{Bibliography (Abridged)}

Adomeit, Hannes, "Russia as a 'Great Power' in World Affairs: Images and Reality", in International Affairs, vol. 71 no. 1, 1995.

Aivazian, Armen, "Possible Solutions for Nagorno-Karabakh Conflict: A Strategic Perspective", in Contemporary Caucasus Newsletter, no. 5, Spring 1998.

Aliev, Salih, Oil and Independence, paper presented at the international conference on the Caucasus and Central Asia, Bilkent University, Ankara, May 1995.

Alieva, Leila, The Foreign Policy of Azerbaijan, FSS Briefing, RIIA Russia and Eurasia Programme, no. 9, October 1996.

Aliyev, Heydar, Dünya Siyasetinde Azerbaycan Petrolü, Istanbul: Sabah Yayinlari, 1998.

Altmann, Christian, and Frank Nienhuysen, Brennpunkt Kaukasus: Wohin Steuert Rußland?, Bergisch Gladbach: Bastei Lübbe, 1995.

Altstadt, Audrey L., "Nagorno Karabakh'Apple of Discord' in the Azerbaijani SSR", in Central Asian Survey, no. 4, 1988.

Altstadt, Audrey L., "Azerbaijan's Struggle Towards Democracy”, in Dawisha and Parrott, (eds.), Conflict, Cleavage and Change in Central Asia and the Caucasus.

Altstadt, Audrey L., The Azerbaijani Turks: Power and Identity under Russian Rule, Stanford: Hoover Institution Press, 1992.

Altunisik, Meliha, ”Turkey's attitude towards the Eurasian Oil: From Euphoria to Pragmatism”, in Marco Polo Magazine, no. 4-5, 1998.

Aras, Bülent, "Post-Cold War Realities: Israel's Strategy in Azerbaijan and Central Asia”, in Middle East Policy, vol. 5 no. 4, January 1998.

Arslanian, Artin H., "Britain and the Transcaucasian Nationalities During the Russian Civil War", in Suny (ed.) Transcaucasia, Nationalism and Social Change.
Arutionov, Sergei, Ethnicity and Conflict in the Caucasus, paper presented at a 1997 symposium of the Slavic Research Center, Hokkaido University.

Asenbauer, Haig, On the Right of SelfDetermination of the Armenian People of Nagorno-Karabakh, New York: Armenian Prelacy, 1995.

Astourian, Stephen H., "In Search of Their Forefathers: National Identity and the Historiography and Politics of Armenian and Azerbaijani Athnogeneses”, in Schwartz and Panossian, Nationalism and History.

Atabaki, Touraj, Azerbaijan: Ethnicity and Autonomy in Twentieth-Century Iran, British Academic Press, 1993.

Atkin, Muriel, Russia and Iran 1780-1828, Minneapolis: University of Minnesota Press, 1980.

Aykan, Mahmut Bali, "Turkish Perspectives on Turkish-US Relations Concerning Persian Gulf Security in the Post-Cold War Era”, in Middle East Journal, Summer 1996.

Azrael, Jeremy R., and Emil A. Payin (eds.) U.S. and Russian Policymaking with Respect to the Use of Force, Santa Monica: RAND Corporation, 1996.

Baev, Pavel, Russia's Policies in the Caucasus, London: RIIA, 1997.

Bennigsen, Alexandre, and S. Enders Wimbush, Muslims of the Soviet Empire: A Guide, London: Hurst \& Co., 1985.

Bildirici, Faruk, Maskeli Leydi-Tekmili Birden Tansu Çiller, Istanbul: Ümit, 1998 (23rd edition).

Birch, Julian, "Border Disputes and Disputed Borders in the Soviet Federal System", in Nationalities Papers, no. 1, 1987.

Blank, Stephen, "Instability in the Caucasus: Old Trends, New Traits", in Jane's Intelligence Review, April and May 1998. 
Bothe, Michael, and Natalino Ronzitti (eds.), The OSCE in the Maintenance of Peace and Security, Hague: Kluwer Law International, 1997.

Bournoutian, George A., "The Ethnic Composition and the Socio-Economic Condition of Eastern Armenia in the First Half of the Nineteenth Century", in Suny (ed.) Transcaucasia, Nationalism and Social Change. Bremmer, Ian and Cory Welt, "Armenia's New Autocrats", in Journal of Democracy, vol. 8 no. 3, July 1997.

Brownback, Sam, "U.S. Economic and Strategic Interests in the Caspian Sea Region: Policies and Implications”, in Caspian Crossroads, vol. 3 no. 2, Fall 1997.

Brzezinski, Zbigniew, The Grand Chessboard: American Primacy and Its Geostrategic Imperatives, New York: BasicBooks, 1997.

Buchheit, Lee C., Secession: The Legitimacy of Self-Determination, New Haven: Yale University Press, 1978.

Buzan, Barry, People, States \& Fear: An Agenda for International Security Studies in the Post-Cold War Era, Hertfordshire: Harvester Wheatsheaf, 1991 (Second Edition).

Bölükbasi, Süha, “Ankara’s Baku-Centered Transcaucasia Policy: Has it Failed?”, in The Middle East Journal, vol. 50 no. 1, Winter 1997. Cheterian, Vicken, Dialectics of Ethnic Conflicts and Oil Projects in the Caucasus, Geneva: PSIS Occasional Paper no. 1, 1997.

Chorbajian, Levon, Patrick Donabedian and Claude Mutafian, The Caucasian Knot-the History and Geo-Politics of Nagorno-Karabagh, London: Zed, 1994.

Clagett, Bruce M., "Ownership of Seabed and Subsoil Resources in the Caspian Sea under the Rule of International Law”, in Caspian Crossroads, vol. 1 no. 3, Summer/Fall 1995.

Coppetiers, Bruno, (ed.), Contested Borders in the Caucasus, Brussels: VUBPress, 1996, p. 77.

Corley, Felix, "Nagorno-Karabakh—An EyeWitness Account”, in Jane's Intelligence Review, April 1994.

Cornell, Svante E., 'The Unruly Caucasus', in Current History, October 1997.

Cornell, Svante E., “A Delicate Balance: Turkey and the Conflict in Nagorno Karabakh", Middle Eastern Studies, vol. 34 no. 1, 1998.

Cornell, Svante E., "International Reactions to Massive Human Rights Violations: The Case of
Chechnia”, in Europe-Asia Studies, vol. 51 no. 1, January 1999.

Cornell, Svante E., "Iran and the Caucasus", in Middle East Policy, vol. 5 no 4, January 1998.

Cornell, Svante E., "Peace or War? The Prospects of Conflicts in the Caucasus," in Iranian Journal of International Affairs, Vol. 9, No.2, Summer 1997.

Cornell, Svante E., "Undeclared War: The Nagorno-Karabakh Conflict Reconsidered", in Journal of South Asian and Middle Eastern Studies, vol. 20 no. 4, Summer 1997, pp. 1-23.

Cornell, Svante E., Conflict Theory and the Nagorno Karabakh Conflict: Guidelines for a Political Solution, Stockholm: Triton, 1997.

Cullen, Robert, "A Reporter at Large”, in The New Yorker, 15 April 1991.

Cutler, Robert M., "U.S. Interests and 'Cooperative Security' in Abkhazia and Karabakh: Engagement versus Commitment”, in Tütüncü, (ed.), Caucasus: War and Peace.

Daghliq Qarabagh: Zäka, Qalíb, Qäläcäk, Baku: Azärbaycan Dövlät Näsriyatí, 1989.

Danielyan, Emil, "Banned Opposition Party has Deep Roots", in Transition, vol. 3 no. 3, 21 February 1997.

Dawisha, Karen and Bruce Parrott, (eds.), Conflict, Cleavage and Change in Central Asia and the Caucasus, Cambridge University Press, 1996.

Dehdashti, Rexane, "Nagorno-Karabakh: A Case-Study of OSCE Conflict Dispute Settlement Mechanism”, in Bothe and Natalino Ronzitti (eds.), The OSCE in the Maintenance of Peace and Security.

Deutsch, Karl W., Political Community and the North Atlantic Area, New Jersey: Princeton University Press, 1957.

Dragadze, Tamara, "The Armenian-Azerbaijani Conflict: Structure and Sentiment”, in Third World Quarterly, No. 1, 1989.

Dudwick, Nora, "Postcommunist Armenia: Images and Realities", in Dawisha and Parrott, (eds.), Conflict, Cleavage and Change in Central Asia and the Caucasus.

Ehmedov, Elçin, Ermänistan Azärbaycana Täcavüzü vä Beynälxalq Täskilatlar, Baku: Tuna, 1998.

Ehteshami, Anoushiravan, From the Gulf to Central Asia: Players in the New Great Game, University of Exeter Press, 1995. 
Elferink, Alex Oude, "Maritime Boundary Delimitations of the Russian Federation", in Journal of Maritime and Coastal Law, no.1, 1997.

Ertan, Nazlan, "Baku-Ceyhan: Pipeline or Pipe Dream”, in Turkish Probe, 17 May 1996.

Fairbanks, Charles H., "The Postcommunist Wars”, in Journal of Democracy, October 1995.

Faurby, Ib, and Märta-Lisa Magnusson, "Truslen fra Syd: Kaukasus i Russisk Sikkerheds-politik" (The threat from the South: The Caucasus in Russian Security Policy), in Vindue mod Øst (Copenhgen) no. 28, 1996.

Fawcett, Louise, Iran and the Cold War: The Azerbaijan Crisis of 1945, Cambridge: Cambridge University Press, 1992.

Feigl, Erich, Un Mythe de la Terreur-Le Terrorisme Arménien, ses Origines et ses Causes, Salzburg: Druckhaus Nonntal, 1991.

Fraser, Niall et. Al., "A Conflict Analysis of the Armenian-Azerbaijani Dispute", in Journal of Conflict Resolution, vol. 34 no. 4, December 1990, pp. 652-677.

Freedman, Robert O., "Russia and Iran: A Tactical Alliance", in SAIS Review, vol. 17 no. 2, 1997.

Freitag-Wirminghaus, Rainer, ”Aserbaidschan: Die Nationalen und Internationalen Auswirkungendes Krieges um Berg Karabach”, Orient, vol. 34 no. 2, 1993.

Fuller, Elizabeth, "Nagorno Karabakh: Can Turkey Remain Neutral?”, in Radio Free Europe/Radio Liberty Research Report, vol. 1 no. 14, 3 April 1992.

Fuller, Elizabeth, "The Ongoing Political Power Struggle in Azerbaijan”, in Radio Free Europe/Radio Liberty Research Report, vol. 1, no. 18, 1 May 1992.

Fuller, Elizabeth, "Turkish-Russian Relations, 1992-1994", in RFE/RL Research Report, 6 May 1994.

Fuller, Elizabeth, "Armenians Demonstrate for Return of Territories from Azerbaijan”, in Radio Liberty Research Bulletin, 20 October 1987.

Fuller, Elizabeth, "Azerbaijan's June Revolution”, in RFE/RL Research Report, vol. 2 no. 32, 13 August 1993.

Fuller, Elizabeth, "Nagorno-Karabakh: The Death and Casualty Toll to Date", in Radio Liberty Research Bulletin, 14 December 1988.

Fuller, Elizabeth, "Paramilitary Forces Dominate fighting in Transcaucasus", in
RFE/RL Research Report, vol. 2 no. 25, 18 June 1993.

Fuller, Elizabeth, "Russia and the Caucasus", in Ingmar Oldberg, (ed.), Priorities in Russian Foreign Policy: West, South or East, Stockholm: Swedish Defence Research Establishment, 1996.

Fuller, Elizabeth, "Russia, Turkey, Iran and the Karabakh Mediation Process", in RFE/RL Research Report, vol. 3 no. 8, 25 February 1994.

Fuller, Elizabeth, "The Karabakh Mediation Process: Grachev versus the CSCE?”, in RFE/RL Research Report, vol. 3 no. 23, 10 June 1994.

Fuller, Elizabeth, "The Thorny Path to an Armenian-Turkish Rapprochement”, in RFE/RL Research Report, vol. 2 no. 12, 19 March 1993.

Fuller, Graham E., Turkey Faces East: New Orientations toward the Middle east and the Old Soviet Union, Santa Moinca, CA: Rand Corporation , 1992.

Furman, Dimitry, and Carl Johan Åsenius, "The Case of Nagorno-Karabakh (Azerbaijan)", in Archer and Jonson (eds.) Peacekeeping and the Role of Russia in Eurasia.

Goble, Paul, "From Myths to Maps: American Interests in the Countries of Central Asia and the Caucasus", in Caspian Crossroads, vol. 3 no. 1, Summer 1997.

Golan, Galia, Russia and Iran-A Strategic Partnership, London: RIIA, 1998.

Golden, Peter B., "The Turkic Peoples and Caucasia”, in Suny (ed.) Transcaucasia, Nationalism and Social Change.

Goldenberg, Suzanne, Pride of Small NationsThe Caucasus and Post-Soviet Disorder, London: Zed Books, 1994.

Goltz, Thomas, "Letter from Eurasia: The Hidden Russian Hand”, in Foreign Policy, no. 92, Fall 1993.

Goltz, Thomas, A Montana Perspective on International Aid and Ethnic Politics in Azerbaijan, n.p.

Goltz, Thomas, Azerbaijan Diary: A Rogue Reporter's Adventures in an Oil-rich, War-torn Post-Soviet Republic, New York: ME Sharpe, 1998.

Gorbachev, Mikhail, "The Karabakh Explosion”, in Memoirs, New York \& London: Doubleday, 1996. 
Gunter, Michael M., "The Armenian Terrorist Campaign against Turkey”, in Orbis, Summer 1983.

Guroian, V., "Faith, Church, and Nationalism in Armenia”, in Nationalities Papers, vol. 20 no. 1, 1992.

Gurr, Ted Robert, and Barbara Harff, Ethnic Conflict in World Politics, Boulder \& Oxford; Westview Press, 1994.

Gurr, Ted Robert, 'Peoples Against States: Ethnopolitical Conflict and the Changing World System', in International Studies Quarterly, no. 3, 1994.

Gürün, Kamuran, The Armenian File: The Myth of Innocence Exposed, New York, N.Y.: St. Martin's Press, 1985.

Gökalp, Ziya, Türkçülügü Esaslari, or the English Translation by Robert Devereux, The Principles of Turkism, Leiden 1968.

Halbach, Uwe, and Andreas Kappeler, (eds.), Krisenherd Kaukasus, Baden-Baden: Nomos Verlagsgesellschaft, 1995.

Hale, Henry E., "Independence and Integration in the Caspian Basin", in SAIS Review, vol. 19 no. 1, 1999.

Halliday, Fred, "Condemned to React, Unable to Influence: Iran and Transcaucasia," in Wright, Goldenberg and Schoefield, (eds.), Transcaucasian Boundaries.

Hashim, Ahmed, The Crisis of the Iranian State, (Adelphi Paper, No.296, 1995).

Heradstveit, Daniel, ed., Tyrkia $i$ det Storpolitiske Brennpunkt, Oslo: NUPI Report no. 221, September 1997.

Herzig, Edmund, Iran and the Former Soviet South, London: Royal Institute for International Affairs, London, 1995.

Hill, Fiona and Pamela Jewett, Back in the USSR-Russia's Intervention in the Internal Affairs of the Former Soviet Republics and the Implications for United States Policy toward Russia, Harvard University: John F. Kennedy School of Government, January 1994.

Hiro, Dilip, "The Azerbaijan Question”, in The Nation, 14 September 1992.

Hofmann, Tessa, "Unter dem Damoklewsschwert von Assimilation und Emigration': Etnische Minderheiten in der Republik Armenien”, in Orient, vol. 38 no. 4, 1997.

Horowitz, Donald, Ethnic Groups in Conflict, Berkeley: University of California Press, 1985.
Hovannisian, Richard (ed.), The Armenian Genocide in Perspective, New Brunnswick, N.J.: Transaction Publishers, 1988.

Hovannisian, Richard G., "Caucasian Armenia between Imperial and Soviet Rule: The Interlude of National Independence", in Suny (ed.) Transcaucasia, Nationalism and Social Change. Hovhannissyan, Nikolay, The Foreign Policy of Armenia, Yerevan: Noyan Tapan, 1998..

Hovhannisyan, Nikolay, "Nagorno-Karabkhskiy Konflikt i Varianty evo Reshenya", in Etnopoliticheskie Konflikty $v$ Zakavkaze: Ikh Istoku i Puti Reshenya, College Park: University of Maryland, 1997, pp. 92-121.

Hovhannisyan, Nikolay, "Status of Neutrality to Nagorno-Karabakh”, Yerevan News, 20-26 November 1997.

Human Rights Watch/ Helsinki, Azerbaijan: Seven Years of Conflict in Nagorno-Karabakh, New York: Human rights Watch, 1994.

Høris, Ole, and Sefa Martin Yürükel, (eds.) Contrasts and Solutions and Solutions in the Caucasus, Aarhus: Aarhus University Press, 1998.

Kaufman, Stuart J., ”An 'International' Theory of Inter-Ethnic War”, in Review of International Studies, vol. 22 no. 2, 1996.

Kaufman, Stuart J., Ethnic Fears and Ethnic War in Karabakh, Paper presented at the International Studies Association meeting, Minneapolis, March 1998.

Kazemzadeh, Firuz, The Struggle for Transcaucasia, Oxford: Oxford University Press, 1951.

Kechichian, Joseph A., and Theodore W. Karasik, "The Crisis in Azerbaijan: How Clans Influence the Politics of an Emerging Republic", in Middle East Policy, Summer 1996.

Le Cornu, Laura, Azerbaijan's September Crisis: An Analysis of the Causes and Implications, RIIA Former Soviet South Briefing, no. 1, January 1995.

Libaridian, Gerard, "Time is on Neither Side", in Gerard Libaridian and Arif Yunusov, New Approaches to Nagorno-Karabakh: A Window of Opportunity?, East-West Institute Policy Brief no. 3, 1998.

Libaridian, Gerard, The Karabakh File, Cambridge, Mass: Zoryan, 1988.

Lunev, Stanislav, "Russia Balks on the CFE, Threatening Regional Security”, in Jamestown Prism, vol. 1 no. 24, November 1995. 
Lunev, Stanislav, "Russia's Ominous New Military Doctrine", in Jamestown Prism, vol. 1 no. 25, December 1995.

MacDougall, James, "A New Stage in U.S.Caspian Sea Basin Relations", in Central Asia (Luleo) no. 5, 1997.

MacFarlane, S. Neil, "The Structure of Instability in the Caucasus", in Internationale Politik und Gesellschaft-International Politics and Society, no. 4, 1995

MacFarlane, S. Neil, and Larry Minear, Humanitarian Action and Politics: the Case of Nagorno-Karabakh, Providence, RI: T. J. Watson Institute for International Studies Occasional Paper no. 25, 1997.

Makovsky, Alan, "The New Activism in Turkish Foreign Policy”, in SAIS Review, vol. 19 no. 1, 1999.

Malkasian, Mark, "Gha-Ra-Bagh!": The Emergence of the National Democratic Movement in Armenia, Detroit, Mich.: Wayne State University Press, 1996.

Mansurov, A. Bielye Piatna Istorii i Perestroika, Baku: Yazííí, 1990

Maresca, John J., "Agony of Indifference in Nagorno Karabakh”, in The Christian Science Monitor, 27 June 1994.

Maresca, John J., "Lost Opportunities in Negotiating the Conflict over NagornoKarabakh”, in International Negotiation, vol. 1 no. 4, 1996.

Maresca, John J., War in the Caucasus: A Proposal for Settlement of the Conflict over Nagorno-Karabakh, Special Report, United States Institute of Peace, July 1994.

Masish, Joseph, "Military Strategy in NagornoKarabakh”, in Jane's Intelligence Review, April 1994.

Matz, Johan, "Analysis of Russian Foreign Policy mid-1990 till mid-1992”, (draft version presented at the department of East European Studies, Uppsala University, 21 January 1999) in Constructing Foreign Policy Discourses: Russia and the Newly Independent States 199095, forthcoming Doctoral Dissertation, Department of Government, Uppsala University. Mesbahi, Mohiaddin, "Russian Foreign Policy and Security in Central Asia and the Caucasus", in Central Asian Survey, vol. 12 no. 2, 1993.

Migdalowitz, Carol, Armenia-Azerbaijan Conflict, Congressional Research Service, 1996.
Mikoyan, Sergo A., "Russia, the US, and Regional Conflict in Eurasia”, in Survival, vol. 40 no. 3, Autumn 1998, pp. 112-26.

Mohsenin, Mehrdad, "Iran's Relations with Central Asia and the Caucasus", in The Iranian Journal of International Affairs, Fall 1995.

Mollazade, Jeyhun, ”The Legal Aspects of the Karabakh Conflict”, in Mehmet Tütüncü, ed., Caucasus: War and Peace, Haarlem: SOTA, 1998.

Motika, Raoul, ”Ideologische Elemente der Iranischen und Türkischen KaukasusPerzeption”, in Halbach and Kappeler, (eds.), Krisenherd Kaukasus..

Mouradian, Claire, ”The Mountainous Karabakh Question: Inter-Ethnic Conflict or Decolonization Crisis?”, in Armenian Review, vol. 43 no. 2-3, 1990.

Nahavandi, Firozeh, "Russia, Iran and Azerbaijan: The Historic Origins of Iranian Foreign Policy”, in Coppetiers, (ed.), Contested Borders in the Caucasus.

Nanay, Julia, "The U.S. in the Caspian: The Divergence of Political and Commercial Interests”, in Middle East Policy, vol. 6 no. 2, October 1998.

Nesibzade (Nesibli), Nesib, "Politics of Oil in Post-Communits Azerbaijan", in Contemporary Caucasus Newsletter, no. 5, 1998.

Nesibzade, Nesib, Bölümüs Azärbaycan, Bütöv Azärbaijan, Baku: Ay-Ulduz Näshriyyatí, 1997.

Nesibzade, Nesib, Iranda Azärbaycan Mäsäläsi: XX Äsrin 60-70-ci Illäri, Baku: Ay-Ulduz Näshriyyatí, 1997.

Nichol, Jim, ”Transcaucasus Newly Independent States: Political Developments and Implications for U.S. Interests”, CRS Issue Brief, 20 December 1996.

Nissman, David, The Soviet Union and Iranian Azerbaijan: The Use of Nationalism for Political Penetration, Boulder: Westview Press, 1987.

Nolyain, Igor, "Moscow's Initiation of the Azeri-Armenian Conflict", in Central Asian Survey, vol. 13 no. 4, 1994.

Nordquist, Kjell-Åke, Autonomy as Conflict Resolution-Experiences from Self-Government after Internal Armed Conflict, Draft Version (January 1997), Uppsala University Department of Peace and Conflict Research.

Oran, Baskin, "The Turkish Approach to Transcaucasia and Central Asia”, in Høyris and 
Yürükel, (eds.), Contrasts and Solutions in the Caucasus.

Petersen, Philip, "Security Policy in Post-Soviet Transcaucasia, in European Security, no. 1, 1994.

Picco, Giandomenico, "The Caspian Region: Is It Really Strategic?”, in Marco Polo Magazine, no. 6, 1998.

Rutland, Peter, "Democracy and Nationalism in Armenia”, in Europe-Asia Studies, vol. 46, no. 5, 1994.

Sabri-Tabrizi, G. Reza, "Azerbaijan and Armenian Conflict and Coexistence", in Ehteshami, From the Gulf to Central Asia.

Saroyan, Mark, "The 'Karabakh Syndrome' and Azerbaijani Politics", in Problems of Communism, September/October 1990.

Schwartz, Donald D. and Razmik Panossian, Nationalism and History: The Politics of StateBuilding in Post-Soviet Armenia, Azerbaijan and Georgia, Toronto: University of Toronto Press, 1994.

Shenfield, Stephen D., "Armed Conflict in Eastern Europe and the Former Soviet Union", in Thomas G. Weiss, (ed.), The United Nations and Civil Wars, Boulder: Lynne Rienner, 1995, p. 43.

Sherwood-Rendall, Elizabeth, "US Policy and the Caucasus", in Contemporary Caucasus Newsletter, Spring 1998.

Smith, Graham, (ed.), The Nationalities Question on the Post-Soviet States, New York: Longman, 1996.

Solyan, Suren, "Entstehungsgeschichte und Aktuelle Probleme des Karabach-Konflikts", in Halbach and Kappeler, (eds.), Krisenherd Kaukasus.

Staar, Richard F., "Moscow's Plans to Restore its Power", in Orbis, vol. 40 no. 3, Summer 1996, p. 376.

Starovoitova, Galina, National SelfDetermination: Approaches and Case-Studies, Providence, RI: T.J. Watson Institute of International Studies, Brown University, 1997, p. 63.

Suny, Ronald Grigor (ed.), Transcaucasia, Nationalism and Social Change, Ann Arbor: University of Michigan Press, 1996 (revised edition).

Suny, Ronald Grigor, "Karabakh: A Soluble Problem", in Contemporary Caucasus Newsletter, no. 1, Winter 1995.
Swietochowski, Tadeusz, "The Problem of Nagorno-Karabakh: Geography versus Demography under Colonialism and in Decolonization”, in Hafeez Malik, ed., Central Asia, Basingstoke: MacMillan, 1994.

Swietochowski, Tadeusz, "The Spirit of Baku”, in Central Asia Monitor, No.4, 1993.

Swietochowski, Tadeusz, Russia And Azerbaijan-A Borderland In Transition, New York: Columbia University Press, 1995.

Swietochowski, Tadeusz, Russian Azerbaijan, 1905-1920 - the shaping of National Identity in a Muslim Community, Cambridge University Press, 1985.

Taheri, Amir, Crescent in a Red Sky: The Future of Islam in the Soviet Union, London: Hutchinson, 1989.

Tarrock, Adam, "Iran and Russia in 'Strategic Alliance'”, in Third World Quarterly, vol. 18 no. 2, 1997.

Tololyan, Khachig, "National SelfDetermination and the Limits of Sovereignty: Armenia, Azerbaijan, and the Secession of Nagorno-Karabakh”, in Nationalism and Ethnic Politics, vol. 1 no 1, Spring 1995, pp. 86-110.

Tütüncü, Mehmet, "The Caucasus Policy of Turkey (1990-97): An Evaluation”, in Tütüncü, ed., Caucasus: War and Peace.

Walker, Christopher, "The Armenian Presence in Mountainous Karabakh", in Wright, Goldenberg and Schofield, (eds.), Transcaucasian Boundaries.

Walker, Christopher, Armenia and KarabaghThe Struggle for Unity, London: Minority Rights Group, 1991.

Walker, Edward, No Peace, No War in the Caucasus: Secessionist Conflicts in Chechnya, Abkhazia and Nagorno-Karabakh, Cambridge, Mass: Harvard University, Kennedy School of Government, Strengthening Democratic Institutions Project, 1998.

Vaserman, Arie, and Rami Ginat, "National, Territorial or Religious Conflict? The Case of Nagorno Karabakh”, in Studies in Conflict and Terrorism, no. 4, 1994.

Winrow, Gareth, Turkey in Post-Soviet Central Asia, London: RIIA, 1995.

Woff, Richard, "The Armed Forces of Armenia”, in Jane's Intelligence Review, September 1994. 
Woff, Richard, "The Armed Forces of Azerbaijan”, in Jane's Intelligence Review, October 1993.

Wright, John F., Suzanne Goldenberg and Richard Schofield, (eds.), Transcaucasian Boundaries, London: UCL Press, 1996.

Yérasimos, Stéphane, “Caucase: Le Retour de la Russie”, in Politique Internationale, no. 1, 1994. Yunusov, Arif, "Karabakh, Nyeft i Politika", in Express-Khronika, 9-15 September 1994.

Yunusov, Arif, Nayemniki v ArmyanoAzerbaijanskoy Voynye”, in Express-Khronika, 6-23 September 1993.
Yunusov, Arif, "Pogromy v Armenii v 19881989 Godakh”, Express-Khronika no. 9, 26 February 1991.

Yunusov, Arif, "The Status of NagornoKarabakh: The Root of Conflict”, in Gerard Libaridian and Arif Yunusov, New Approaches to Nagorno-Karabakh: A Window of Opportunity?, East-West Institute Policy Brief no. 3, 1998.

Yunusov, Arif, Statistics of the Karabakh War, Baku: Institute for Peace and Democracy, March 1996, p. 5.

Zverev, Alexei, "Ethnic Conflicts in the Caucasus 1988-94", in Coppetiers, (ed.), Contested Borders in the Caucasus. 